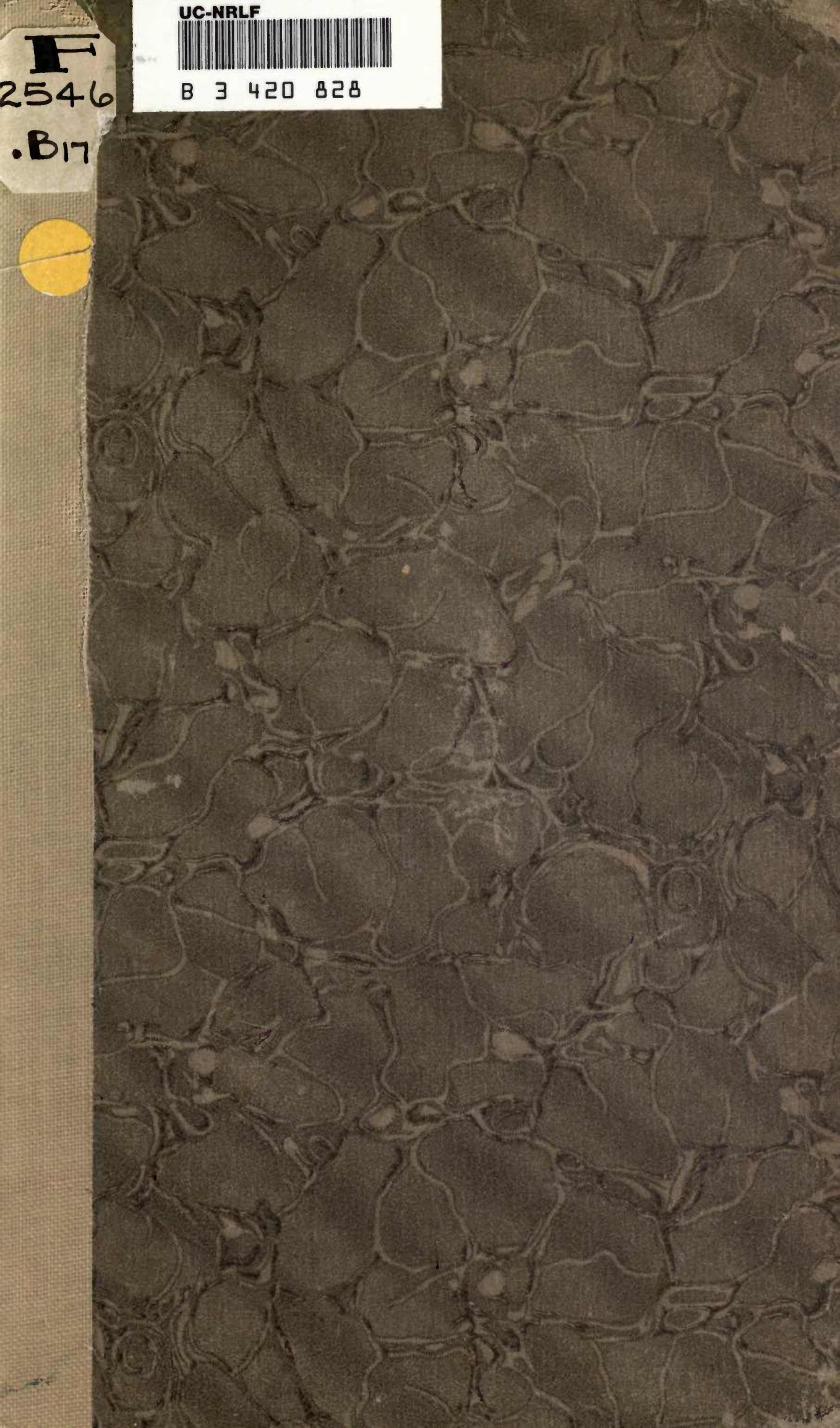




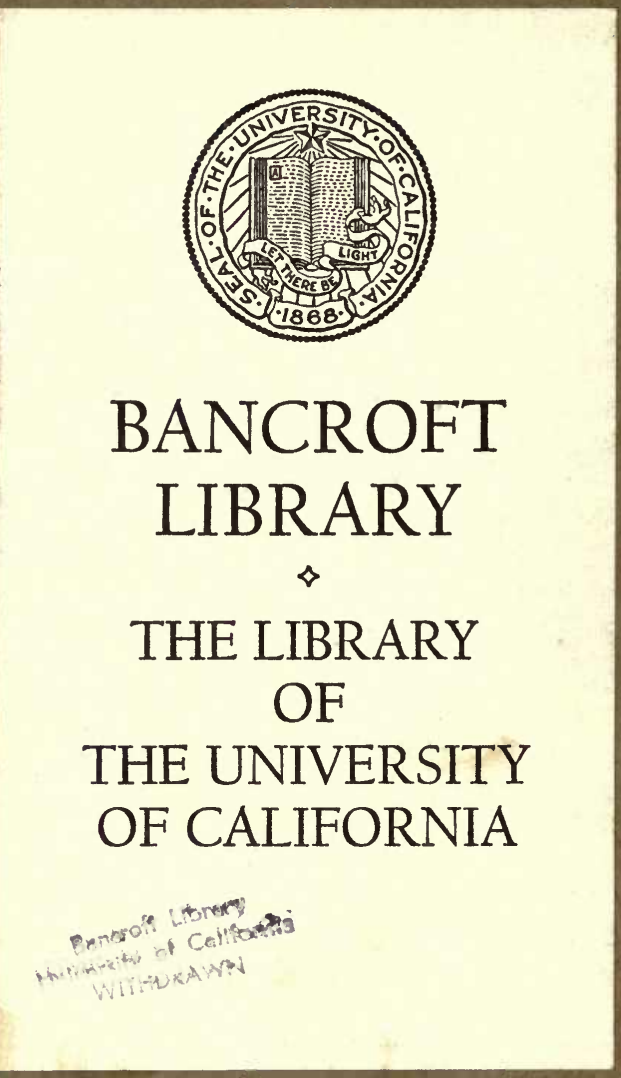




\section{QANCWE. UIBRARY}

PUBLI8HEO
PONTHLY WITHEAWPV

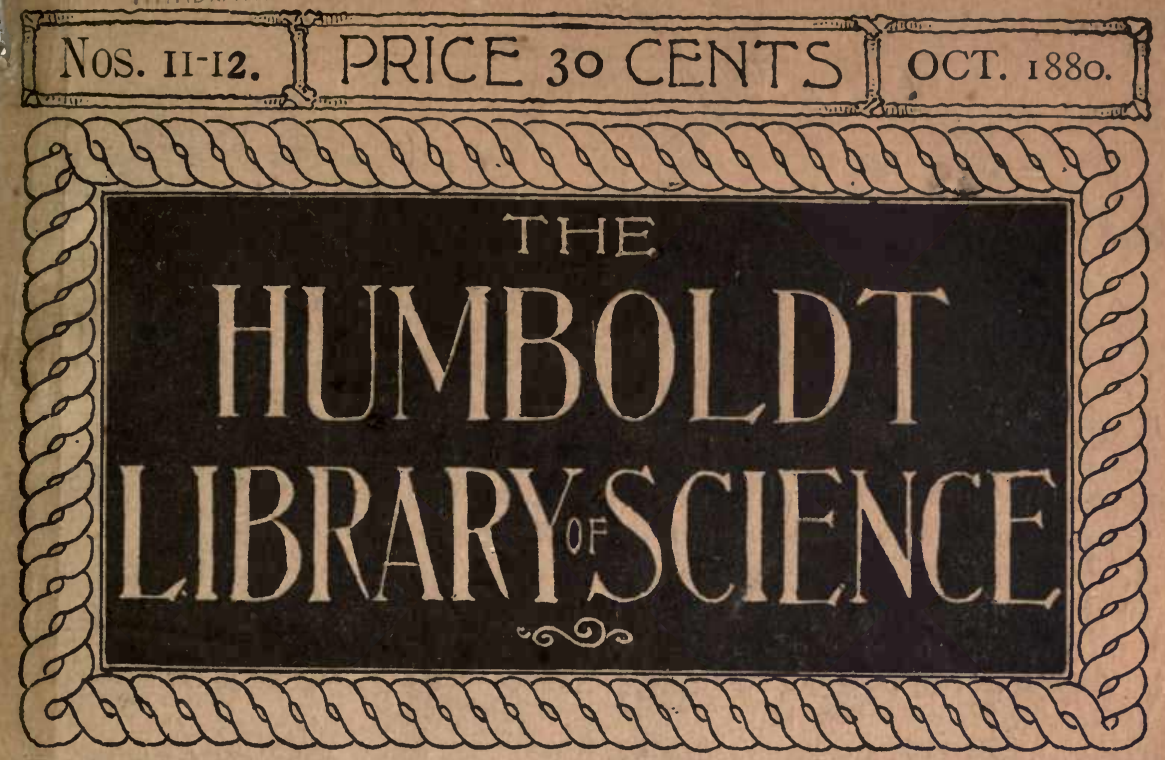

\section{THE NATURALIST} ox тне

RIVER AMAZONS

BY

HENRY W. BATES NEW YORK
THE HUMBOLDT PUBLISHING COMPANY
19 ASTOR PLACE 


\section{$F=546$}

\section{Bi7}

A Remarkable Book.-Edward Bellamy.

\section{THE \\ KINGDOM OF THE UNSELFISH; \\ OR, EMPIRE OF THE WISE.} By JOHN LORD PECK.

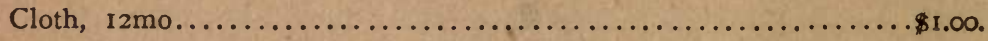

"Should be re-read by every seeker after truth."-Rockıand Independent.

"Polished in style and very often exquisite in expression." -Natick Citizen.

"The book is interesting throughout, and the more widely it is read the better." tion."-Twentieth Century.

"Shows profound research, original ideas, and what might be almost called inspiration."-Sunday Times (Tacoma).

"The effort is noble, and the author has not escaped saying many profound and true things."-Christian Union.

"One of a large number of 'reformatory' volumes now being printed, but it is better than many of them."-Truth Seeker.

"The book is from a widely-read man, and is written for a high end. In its intellectual and 'spiritual ' aspects, it is educative and stimulating."-The Nerw Ideal.

"The book before us is one of the signs of the times. It prophesies a new age, and exhorts to the life which shall further its coming."-New Church Messenger.

"The book is a natural product of the prophetic element of the times, which is reaching forward into the new economic age we are just entering."-Teacher's Outlook.

"The chapters on 'Natural and Social Selection' are among the most interesting in the book, and require close reading to take in the whole drift of their meaning."-Detroit Tribune.

"It is a real contribution to original and advanced thought upon the highest themes of life and religion - of intellectual, moral, social, material and spiritual progress." - The Unitarian.

"There are many golden sentences in the chapter on Love, and the practical good sense shown in the treatment of the marriage question would help many husbands and wives to live more happily together."-The Dawn.

"This a new and thoroughly original treatment of the subjects of morality, religion and human perfectibility, and furnishes a new ground for the treatment of all social ques. tions. It is radical and unique."-The Northwestern.

"It is in no sense an ordinary work. It makes strong claims and attempts to carry out the largest purposes. Taking the standpoint of science, it attacks the gravest problems of the times with an endeavor to show that the most advanced science will enable us to reach the most satısfactory conclusions."-Chicago Inter-Ocean.

"One of the most important recent works for those who are striving to rise into a nobler life, who are struggling to escape the thraldom of the present selfish and pessimistic age. Many passages in Mr. Peck's work strongly suggest the lofty teachings of those noblest of the ancient philosophers, the Stoics. Those who are hungering and thirsting after a nobler existence will find much inspiration in "The Kingdom of the Unselfish." "The Arena.

\section{THE HUMBOLDT PUBLISHING CO.}




\section{8 \\ Bancroft Librect}

Bancrolf librery

University of Cellioprils

WITHOR:WM

\section{PRESERVATION
COPYADDED
ORIGINAL TOBE
RETAINED


NOV $2 \quad 1992$ \\ PRESERVATION
COPYADDED
ORIGINAL TOBE
RETAINED


NOV $2 \quad 1992$ \\ PRESERVATION
COPYADDED
ORIGINAL TOBE
RETAINED


NOV $2 \quad 1992$ \\ PRESERVATION
COPYADDED
ORIGINAL TOBE
RETAINED


NOV $2 \quad 1992$}

\section{THE NATURALIST ON THE RIVER AMAZONS.}

\section{A RECORD OF ADVENTURES, HABITS OF ANIMALS, SKETCHES OF BRAZILIAN AND INDIAN LIFE, AND ASPECTS OF NATURE UNDIR THE EQUATOR, DURING ELEVIN YEARS OF TRAVEL.}

BY

\section{HENRY WALTER BATES, F.L.S.,}

\section{(Assistant Secretary to the Royal Geographical Society of England.)}

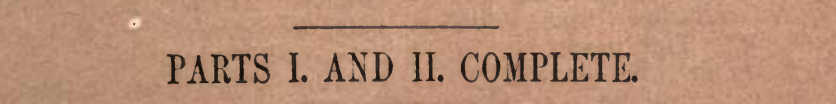

\section{CHAPTER I.}

\section{PARÁ.}

Amival-Aspect of the country-The Para river-First walk in the suburbs of Park-Birds, Lizards, and Insects of the suburbs-Leaf-carrying Ant-Sketch of the climate, history, and present condition of Pará.

I EMBARKED at Liverpool, with Mr. Wallace, in a : mall trading vessel, on the 26 th of April, 1948 ; and, after a swift passage from the Irish Channel to the equator, arrived, on the 26th of May, off Salinas. This is the pilot-station for vessels bound to Para, the only port of entry to the vast region watered by the Amuznas. It is a small village, for. merly a missionary settlement of the Jesuits, situated a few miles to the eastwurd of the Pará river. Here the ship anchored in the open sea, at a distunce of six miles from the shore, the shallowness of the water far out around the mouth of the great river not permitting in safety a nearer approach ; and the signal was hoisted for a pilot. It was with deep interest that my companion and myself, both now about to see and examiue the beallties of a tropical country for the first time, gazed on the land where I, at least, eventually spent eleven of the best years of my life. To the eastward the country was not remarkable in appearance, being slightly undulating, with bare sand-hills and scattered trees; but to the westward, stretching toward the mouth of the river, we could see through the captain's glass a long line of forest, risiug apparently out of the water; a densely-packed mass of tall trees, broken into groups, and finally into single trees, as it dwindle a way in the distance. This was the frontier, in 


\section{THE NATURALIST OT TIE RIVER AMAZONS.}

this direction, of the great primeval forest characteristic of this region, which contains so many wonders in its recesses, and clothes the whole surface of the country for two thousand miles from this point to the fout of the Andes.

On the fullowing day and night we sailed, with a light wind, partly aided by the tide, up the Pará river. Toward evening we passed Vigia and Colares, two fishing villages, and saw many native canoes, which seemed like toys beneath the lofty walls of the dark forest. The air was excessively close, the sky overcast, and sheet lightning played almost incessantly around the horizon, an approp' iate greeting on the threshold of a conntry iving close under the equator! The evening was calm, this being the seasun when the winds are not strong, so we glided along in a noiseless manner, which contrasted pleasantly with the unceasing turmoil to which we had been lately accustomed on the Atlantic. The immensity of the river struck us greatly, for although sailing sometimes at a distunce of eight or nine miles from the eastern bank, the opposite shore was at no time visible. Indeed, the Para river is thirty-six miles in breadth at its mouth; and at the city of Pará, nearly seventy miles from the sea, it is twenty miles wide; but at that point a series of islands enmmences, which contracts the river view in front of the port.

On the morning of the 28th of May we ar. rived at our destination. The appearance of the city at sunrise was pleasing in the highest degree. It is built on a low tract of land, having only one small rocky elevation at its southern extremity; it therefore affords no amphitheatral view from the river; but the white buildings rooferl with red tiles, the numerous towers and cupolas of churches and conveuts, the crowds of palm-trees reared above the buildings, all sharply define I against the clear blue sky, give an appearance of lightness and cheerfulness which is most exhilarating. The perpetual forest hems the city in on all sides landward; and toward the suiburhs picturesque country huuses are seen scattered about, half buried in luxuriant foliage. The port vas full of native canoes and other vessels, large and small ; and the singing of bells and firing of rickers, announcing the dawn of sume Roman Catholic festival day,' showed that the $p$ ipulation was astir at that early hour.

The impressions received during our first walk, on the evening of the day of our arrival, cau never wholly fade from my mind. After traversing the few streets of tall, gioumy, convent-looking buildings near the port, inhabited chietly by merchants and shnpkeepers; along which idle soldiers, dressed in slinby uniforms, carrying their muskets carelessly over their arms, priests, negresses with red water-jars on their lieads, sad-looking Indian women carrying their nakel children astride on their hips, und other sampies of the motley life of the place, were seen: we passed down a long uarrow street leading to the suburbs. Beyond this, our road lay acruss a grassy common into is picturesque lane leading to the virgin forest. The long street was inhabited by the poorer class of the population. The houses were of one story only, and had an irregular an 1 mean appearance. The windows were witlout glass, having, instead, projecting lattice casements. The street was unpaved, and inches deep in lonse sand. Groups of people were cooling themselves outside their voors -people of all shades in color of skin, Euro pean, negro and Indian, but chiefly an uncertain mixture of the three. Amoug then: were several handsome women, dressed in a slovenly manner, barefuot or shod in loose slippers; but wearing richly decorated earrings, and around their necks strings of very large gold beals. They had dark expressive eyes, and remarkably rich hearls of hair. It was a mere fancy, but I thought the mingled squalor, luxuriance, and beauly of these women were pointedly in hitrmon y with the rest of the scene; so striking, in the view, was the mixture of nalural riches and human poverty. The houses were mostly in a dilapidated condition, and signs of indolence and neglect were every where visible. The wooden palings which surrounded the weed-grown gardens were strewn about, brolren ; and hogs, goats, and ill-fed poultry wandered in and out through the gaps. But amid all, and compensating every defect, rose the overpowering be:tuty of the vegetation. The massive dark crow us of shady mangoes were seen every where among the dwellings, amid fragrant blossoming orange, lemun, and many other tropical fruit-tsees; some in flower, others in fruit, at varying stiges of ripeness. Here and there, shooting above the more dome-like and sombre trees, were the smosth columnar stems of palms, bearing aloft their magnificent crowns of finely cut fronds. Among the latter the slim assaipalm was especially noticeable, growing in groups of four and five; its smooth, gentlycurving stem, twenty to thirty feet high, terminating in a head of feathery foliage, inexpressibly ligbt and elegant in outline. On the boughs of the taller and more ordinarylooking trees sat lufts of curiously-leaved parasites. Slender woody lianas hung in festoons from the branches, or were suspended in the form of cords and ribbons; while ilixuriant creeping plants overran alike tree-trunks, roofs and walls, or toppled over palings in copious profusion of foliage. The superb banana (Musa paradisiaca), of which I had always read as forming one of the charms of tropical vegetation, here grew with great luxuriance. its glossy velvety-green lf aves, $t$ welve feet in leugth, curving over the roufs of verandas in the rear of every house. The shape of the leaves, the varying shades of green which they present when lightly moved by the wind, and especiaily the contrast they afford in color and form to the more sombre hues and more rouuded outline of the other trees, are quite sufficient to acwunt far the chitrm of this gloriuus tree. 
Strange forms of vegetation drew our attention at almost every step. Among them were the different kinds of Bromelia, or pine-apple plants, with their long, rigid, sword-shuped leaves, in some species jagged or toothed alung their edycs. Then there was the bread-fruit-tree-an importation, it is true; but remarkable for its large, glossy, darkgreen, strongly digitated foliage, and its interesting history. Many other trees and plants, curious in leaf, stem, or manner of growth, grew on the borders of the thickets slong which lay our road; they were all uttractive to new-comers, whose last country ramble, of quite recent date, was over the bleak moors of Derbyshire on a sleety morning in April.

As we continued our walk the brief twilight cummenced, and the sounds of multifarious life came from the vegetation around. The whil ring of cicadas; the shrill stridulation of a vast number and variety of field crickets and grasshoppers, each species sounding its peculiar note ; the plaintive hooting of tree frogs-all blended together in one con. tinuous ringing sound - the audible $\mathrm{expression}$ of the teeming profusion of nature. As night came on, many species of frogs and toads in the marshy places joined in the chorus ; their eroaking and drumming, far louder than anything I had before heard in the same line, being added to the other noises, created an almost deafening din. This uproar of life, I afterward found, never wholly ceased, night or day: in course of time $I$ became, like other residents, accustomed to it. It is, however, one of the peculiarities of a tropicalat least a Brazilian-climate which is most likely to surprise a strunger. After my return to England, the death-like stillness of summer days in the country appeared to me as strange as the ringing uproar did on my first arrival at Pará. The ohject of our visit being accomplished, we returned to the city. The fire-flies were then out in great numbers, flitting about the sombre wonds, and even the frequented streets. We turned into our hammocks, well pleased with what we had seen, and full of anticipation with regard to the wealth of natural objects we had come to explore.

During the first few days we were em. ployed in landing our baggage and arranging our extensive apparatus. We then accepted the invitation of the cousignee of the vessel to make nse of his rocinha, or country-house in the suburbs, until we finally decided on a residence. Upon this we made our first essay in housekeeping. We bought cotton hammocks, the universal substitute fur beds in this country, cooking utensils, and crockery, and engaged a free negro, nanied Isidoro, as cook and servant of all work. Our first walks were in the immediate suburhs of Pará. The city lies on a corner of land formed by the junction of the river Guamá with the Pará. As I have said before, the forest which covers the whole coun. try extends close up to the city streets; indeed, the town is built on a tract of cleared land, and is kept free from the jungle only by the constuut care of the Government. The surface, though everywhere low, is slightly undulating, so that areas of dry land alternate throughout with areas of swampy ground, the vegetation und animal tenunts of the two being widely different. Our resi. dence lay on the side of the city nearest the Guamá, on the borders of oue of the low and swampy ureas which bere extends orer u portion of the suburbs. The tract of land is in. tersected hy well macadanized suburban roads, the chief of which, Estrada dus Mongubeiras (the Monguba road), about a mile long, is a magnificent arenue of silk-cottontrees (Bombax monguba and $B$. ceiba), huge trees whose trucks taper rapidly from the ground upward, and whose flowers hefore opening look like red balls studding the branches. This fine road was constructed under the governorship of the Count dos Arcos, about the ycar 1812. At right ungles to it run a number of narrow green lanes, and the whole district is diained by a system of small canals or trenches through which the tide ebbs and flows, showing the lowness of the site. Before I left the countiy, other enlerprising presidents had formed a number of avenues lined with cocca-nut palms, almond and other trees, in contiuuation of the Moguba road, over the more elevated and dice ground to the north-east of the city. On the high ground the vegetation has an as pect quite different from that which it presents in the swampy parts. Iudeed, with tho exception of the palm-trees, the suburbs here huve an aspect like that of a village grecn at home. The soil is sandy, and the open com. mons are covered with a short grassy and shrubby vegetation. Beyond this, the land again descends to a marshy tract, where, at ine bottom of the moist hollows, the public wells are situated. ITere all the linen of the city is washed by hosts of noisy ncgresses, and here ulso the wuter-carts are filledpainted hogsheads on wheels, drawn by bullucks. In early morning, when the sun some times shines through a light mist, and everything is dripping with moisture, this part of the city is full of life: vociferous negroes and wrangling Gallegos, the pro. piietors of the water-carts, are gathered about, jabbering contiuually, and taking their morning crums in dirty wine-shops at the street corne1s.

Along thesc beautiful roads we found much to interest us during the fist $f \in w$ days. Suburbs of towns, and open, sunny, cultivated places in Brazil, are tenuuted by species of animals and plants which are mostly different from those of the dense primeval forests. I will, therefore, give an account of what we observed of the animal world, during our explorations in the immediate neighborbood of Pará.

The number and beauty of the birds and insects did not at first equal our expectation. 
The majority of the birds we saw were small and obscurely colored; they were indeed similar, in generul appearance, to such as are met with in country places in Eugland. Occasionally a flock of small paroquets, green, with a patch of yellow on the forehead, would come at early morning to the trees near the Estrada. They would feed quietly, sometimes chattering in subdued tones, but setting up a harsh scream, aud flying off, on being disturbed. Humming-birds we did not see at this time, although $I$ afterwarc. found them by hundreds when certain trees were in flower. Vultures we only suw at a distance, sweeping round at a great height, over the public slaughter-bouses. Several fly-catchers, finches, ant-thrushes, a tribe of plainly-colored birds, intermediate in structure between fly-catchers and thrushes, some of which startle the new-comer by their extranrdinary notes emitted from their places of concealment in the dense tlickets; and also tanagers, and other small birds, inhabited the neighborhood. None of these had a pleasing song, except a little brown wren (Troglody tes furvus), whose voice and melody resemble those of our English robin. It is often seen, hopping and climbing about the walls and roofs of houses and on trees in their vicinity. Its sung is more frequently heard in the rainy season, when the mongubatrees shed their leaves. At those times the Estrada das Mongubeiras has un appearance quite unusual in a tropical country. The tree is one of the few in the Amazons region which sheds all its fuliage before any of the new leaf-buds expand. The naked branches, the sodden ground matted with dead leaves, the gray mist veiling the surrounding vegetation, and the cool atmosphere soon after sunrise, all combine to remind one of autumnal mornings in England. While loitering about at such times in a balf-oblivious mood, thinking of home, the song of this bird would create for the moment a perfect illusion. Numbers of tanagers frequented the fruit and other trees in our garden. The two principal kinds which attracted our at tention were the Rhamphocolus jacapa and the Tanagra episcopus. The females of hoth are dull in color, but the male of Jacapa has a beautiful velvety purple and black plumage, the beak being pastly white, while the same sex in Episcopus is of a pale blue culor, with white spots on the wings. In their hahits they both resemble the common house sparrow of Europe, which does not exist in $\mathrm{S}$ mill America, its place being in some moasure filled by these famiiiar tanagers. They are just as lively, restless, bold, and wary; their notes are very similar, chirping and inliarmonious, and they seem to be almost as fond of the $n$ ighborhood of man. They do not, however, build their nests on houses.

Another interesting and common bird was the Japim, a species of Cassicus (C. icteronotus). It belongs to the same family of birds as our starling, magpie, and rook, and has a rich yellow and biack plumage, remarkably compact and velvety in texture. The shape of its head and its physioguomy are very similar to those of the magpie; it has light gray eyes, which give it the same knowing expression. It is social in its habits, und builds its nest, like the English rook, on trees in the neighborhood of habitations. But the nests are quite differently constructed, being shaped like purses, two feet in length, and suspended from the slender branches all round the tree, some of them very near the ground. The entrance is on the side near the bottum of the nest. The bird is a great favorite with the Brazilians of Pará : it is a noisy, stirring, babbling creature, passing cunstantly to and fro, chattering to its comrades, and is very ready at imitating other birds, especially the dumestic poultry of the vicinity. There was at one time a weekly newspaper published at Pará, called The Japim; the name being chosen, I suppose, on account of the babbling propensities of the bird. Its eggs are nearly round, and of a bluish-white color, speckled with brown.

Of other vertebrate animals we saw very little, except of the lizurds. They are sure to attract the attention of the new-comer from Nortliern Europe, by reason of their strange appearance, great numbers and variety. The species which are seen crawling over the walls of buildings in the city are different from those found in the forest or in the interior of houses. They are unpleasantlooking animals, with colors assimilated to those of the dilapidated stone and mud walls on which they are seen. The house lizards belong to a peculiar family, the Geckos, and are found even in the best-kept chumbers, most frequently on the walls and ceilings, to which they cling motionless by day, being active only at night. They are of speckled gray or ashy colors. The structure of their feet is beautifully adapted for clinging to and running over smooth surfaces; the under side of their toes being expanded into cushions, beneath $w$ hich folds of skin form a series of flexible plates. By means of this aprasatus they can walk or run across a smovih ceiliug with their backs downward: the plated soles, by quick muscular action, exbausting aud admitting air alternately. The Geckos are very repulsive in appearance. The Bruzilians give them the name of Osgas, and firmly believe them to be poisonous; they are, however, harmless creatures. Those found in houses are small; but I have seen others of great size, in crevices of tree trunks in the forests. Sometimes Geckos are found with forkerl tails ; this results from the budding of a rudimentary tail at the sirle, from an injury done to the member. A slight rap will cause their tails to snap off, the loss being afterward partially repaired by a new rowth. The tails of lizards seem to be alnost useless appendages to the auimals. I usod often to amuse myself in the suburbs, whi'e resting in the verandah of vur house during the leat of midday, by watehing the variesated green, brown, and yellow ground. lizards. They would come nimbly forward. 
and commence grubbing with their fore feet and snouts around the roots of herbage,searching for insect larva. On the slightest alarm they will scamper off ; their tails cocked up in the air as they waddled awkwardly away, evidently an incumbrance to them in their flight.

Next to the birds and lizards, the insects of the sıburbs of Pará deserve a few remarks. I will pass over the many other orders and families of this class, and proceed at once to the ants. These were in great numbers everywhere, but I will mention here only two kinds. We were amazed at seeing ants an iuch and a quarter in length, and stout in proportion, marching in single file through the thickets. These belonged to the species called Dinoponera grandis. Its colonies consist of a small number of individuals, and are

.3

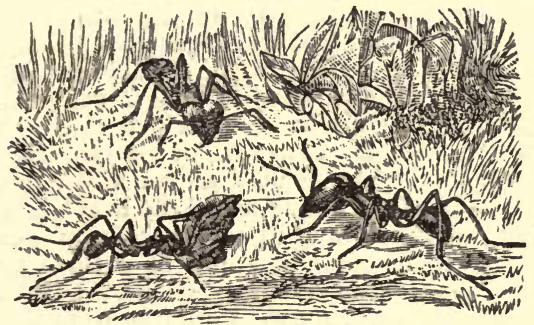

Saüba or Leaf-carrying Ant.-1. Working-minor: 2. Working-major; 3. Subterranean worker.

established about the roots of slender trees. It is a stinging species, but the sting is not so severe as in many of the smaller kinds. There was nothing peculiar or attractive in the habits of this giunt among the ants. Another far more interesting species was the Saüba (Ecodoma cephalotes). This ant is seen every where about the suburbs, marching to and fro in broad columns. From its habit of despoiling the most valuable cultivated trees of their foliage, it is a great scourge to the Brazilians. In some districts it is so aloundant that agriculture is almost impossible, aud everywhere complaints are heard of the terrible pest.

The workers of this species are of three orders, and vary in size from two to seven lines; some idea of them may be obtained from nthe accompanying wood-cut. The true working-cluss of a colony is formed by the small-sized order of workers, the worker-minurs as they are called (Fig. 1). 'Tlie lwo other kinds, whose functions, as we shall see, are not yet properly understood, have eurimmously swrillen and mussive heads; in one (Fig. 2). the head is lighly polished; in the other (Fig. 3), it is opaque and hairy. "The wurker-minurs vary greatly in size, some being clouble the bulk of others. The entire body is of very solid consistence, and of a pale reddish-brown culor. The thorax or middle segment is armed with three pairs of :sharp spines; the head, also, has a pair of similar spines proceeding from the cheeks behind.

In our first walks we were puzzled to ac. count for large mounds of earth, of a differ-. ent color from the surrounding soll, which were thrown up in the plantations and woods. Some of them were very extensive, being forty yurds in circumference, but not more than two feet in height. We soon ascertained that these were the work of the Saübas, being the vutworks, or domes, which overlie and protect the entrances to their vast subterranean galleries. On close examination, I found the earth of which they are composed 10 consist of very minute granules, agglomerated without cement, and forming many rows of little ridges and turrets. The difference in color from the superficial soil of the vicinity is owing to their being formed of the undersoil, brought up from a considerable depth. It is very rarely that the ants are seen ut work on these mounds; the entrances seeem to be generally closed; only now and then, when some particular work is going on, are the gallerics opened. The entrances are small and numerous ; in the large hillocks it would require a great amount of excavation to get at the main galleries; but I succeeded in removing portions of the dome in smaller hillocks, and then I found that the minor entrances converged, at the depth of about two feet, to one broad elaboratelyworked gallery or mine, which was four or five inclues in diameter.

This habit in the Saubba ant of clipping and carrying away immense quantities of leaves has long been recurded in books on nutural history. When employed on this work, their processions look like a multitude of animated leaves on the march. In some places I found an accumulation of such leaves, all circular pieces, about the size of a sixpence, lying on the pathway unattended by ants, and at some distance from any colony. Such heaps are always found to be removed when the place is revisited the next duy. In course of time I had plenty of opportunities of seeing them at work. They mount the tree in mul titudes, the individuals being all workerminors. Each one places itself on the surface of a leaf, and cuts with its sharp scissorlike jaws a nearly semicircular incision on the upper side; it then takes the edge between its juws, und by a sharp jerk detaches the piece. Sometimes they let the leaf drop to the ground, where a little houp accumulates, until carried off by another relay of workers ; but, generally, each marches off with the piece it has operated upun, and us all take the same road to their colony, the path they follow becomes in a short time smootl and bare, looking like the impression of a cart-wheel through the herbage.

It is a most interesting sight to see the vast host of busy diminutive laborers occupied on this work. Unfortunately they choose cultivated trees for their purpose. This ant is quite peculiar to tropicul America, as is the entire genus to which it belongs; it sometimes despoils the young trees of species growing wild in its native forests ; but seems to prefer, when within reach, plants imported from other countries, such as the coffee and orange trees. It has not hitherto been 
shown satisfactorily to what use it applies the leaves. I discovered this only after nuch time spent in investigation. The leases are used to thatch the domes which cover the entrances to their subterranean dwellings, thereby protecting from the deluging rains theyoung bruods in the nests beneath. The iarger mounds, already described, aı e so extensive that few persons would attempt to remove them for the purpose of examining their interior ; but smaller hillocks, covering other entrances to the same systemrof tunnels and chambers, may be found in sheltered places, and these are always thatched with leaves, mingled with grauules of earth. The heavily-laden workers, each carrying its seyment of leaf vertically, the lower edge secured in its mandibles, troop up and cast their burdens on the hillock; another relay of laborers place the leaves in position, covering them with a layer of earthy granules, which are brought one by one from the suil beneatl.

The underground abodes of this wonderful ant are known to be very extensive. The Rev. Hawlet Clark has related that the Saüba of Rio de Janeiro, a species closely allied to curs, has excavated a tunnel under the bed of the river Paraluyba, at a place where it is as broad as the Thames at London Bridge. At the Magoary rice-mills, near Pas á, these ants once pierced the embankment of a large reservoir : the great body of water which it contained escaped before the damage could be repaired. In the Butanic Gardens, at Pará, an enterprising French gardener tried all he could think of to extirpate the Sauba. With this object he made fires over some of the main entrances to their colonies, and blew the fumes of sulphur down the galleries by means of hellows. I saw the smoke issue from a great number of outlets, one of which was seventy yards distant from the place where the bellows were used. This shows how extensively the underground galleries are ramitied.

Besides injuring and destroying young trees by despoiling them of their foliage, the Sauba ant is troublesome to the inhabitants from its habit of plundering the stores of provisions in houses at night, for it is even more active by night than in the day-time. At first I was inclined to discredit the stories of their entering habitations and carrying off grain by grain the farinha or mandioca nieal, the bread of the poorer classes of Brazil. At kength, while residing ut au Indian village on the Tapajos, I had ample proof of the fact. One niglit my servant woke me three or four hours before sunrise by calling out that the rats were robbing the farinlia baskets; the article at that time being scarce and dear. I got up, listened, and found the noise was very unlike that made by rats. So I took the light and weut into the storeroom, which was close to my sleeping-place. I thete found a broad column of Saülra ants, consisting of thousands of individuals, as bus as possible, passiug to and fro beiriceu the civus and my precious baskels. Must of thoso passing outward were laden each with : grain of farinha, which was, in some cases, larger and many times heavier than the budies of the carriers. Farinlia consists of graius of sirnilar size and appearance to the tapioca of our shops; both are pruducts of the same root, tapioca being the pure sturch, and farinha the starch mixed with woody fibre, the latter ingredient giving it a yellowish. color. It was amusing to see sume of the dwarfs, the smallest members of their family, staggering along, completely hidden undertheir load. The baskets, which were on a. high tahle, were entirely covered with ants, many bundreds of whom were employed in snipping the dry leaves which served as lining. This produce the rustling sound which had at first disturbed us. My servant told me that they would carry off the whole contents of the two baskets (about two busliels) in the cirurse of the night, if they were not. driven oft ; so we tried to exterminate therk by killing them with our wooden clogs. It was impossible, however, to prevent fresh hosts coming in as fast as we killed their companions. They returned the next uight ; and I was then obliged to lay trains of gunpowder along their line, and blow them up. This, repeated many times, at last seemed to: intimidate them, for we were free from their visits during the remainder of my residence at the place. What they did with the liard dry grains of mandioca I was never able to uscertain, and cannot even conjecture. The miesl contains no gluten, and therefore would be useless as cement. It contuins only a snall relative portion of starch, and, when mix $0_{0}$ with water, it separates and falls away like so much earthy matter. It maj serve: as foud for the subterranean workers. But. the young or larræ of ants are usually fed by juices secreted by the worker nurses.

Ants, it is scarcely necessary to observe, consist, in each species, of three sets of individuals, or, as some express it, of three sexes -namely, mules, females, and workers ; the last-mentioned being undeveloped females. The perfect sexes are winged on their first attainiug the adult state; they alone propugate their kind, flying away, previous to the act of reproduction, from the nest in which they lave been reared. This winged state of the perfect ma'es and females, and the habit of flying abroad before pairing, are very important points in the economy of ants; for they are thus enubled to intercross with members of distant colonies which swarm at the same time, and thereby increase the vigur of the race, a proceeding essential to the pros. perity of any species. In mauy ants, especially those of tropical climates, the workers, again, are of two classes, whose structure and functions are widely different. In some siecies they are wonderfully unlike each other, and constitute two well-difined forms of workers. In cthers, the re is a gradation if individuals between the two extremes. The curivus differences in structure and 
habits between these two classes form an interesting but very difficult study. It is one of the great peculiarities of the Sauba ant to possess three classes of workers. My investigations regarding them were far from complete; I will relate, however, what I have observed on the subject.

When engaged in leaf-cutting, plundering farinla, and other operations, two classes of workers are always seen (Figs. 1 and 2 , page 3$)$. They are not, it is true, very sharply defined in structure, for individuals of intermediate grades occur. All the wolk, however, is done by the individuals which Jure small heads (Fig. 1), while those which have enormously large heads, the workermajors (Fig. 2), are observed to be simply walking about. I could never satisfy myself as to the function of these worker-majors. They are not the soldiers or defenders of the working portion of the community, like the armed class in the Termites, or white unts; for they never fight. The species has no sting. and does not display active resistance when interfered with. I once imagined they exercised a sort of superintendence over the others; but this function is entirely unneces. sary in a community where all work with a precision and regularity resembling the subordinate parts of a piece of machinery. I came to the conclusion, at last, that they huve no very precisely defined function. They cannot, however, be entirely useless to the community, for the sustenunce of an idle class of such bulky individuals would be too heavy a charge for the species to sustain. I think they serve, in some sort, as passive instruments of protection to the real workers. Their enormously large, hard, and indestructible heads may be of use in protecting them against the attacks of insectivorous animals. They would be, on this view, a kind of "pièces de resistance," serving as a foil against onslaughts made on the main body of workers.

The third order of workers is the most curious of all. If the top of a small fresh hillock, one in which the thatching process is going on, be taken off, a broad cylindrical shaft is disclosed, at a depth of about two feet from the surface. If this be probed with r stick. which may be done to the extent of three or four feet without tunching bottom, : a smal! numher of colossal felluws (Fig. 3) will sluwly begin to make their way up the : smocth sides of the mine. Their lieads are of the same size us those of the class Fig. 2 ; but the front is clothed with hairs, instead of being polished, and they have in the middle - of the forehead a twin ocellus, or simple eye, of quite different structure from the ordinary c'mpound eyes on the sides of the head. "This frontal eye is totally wanting in the nther workers, and is not kuown in any other kind of ant. The apparition of these strange creatures from the cavernous depths of the - mine reminded me, when I first observed them, of the Cyclopes of Homeric fable. -They were not very pugnacious, as I feared they would be, and I had no difficulty in securing a few with my fingers. I never saw them under any other circumstances than those here related, and what their special functions may be I cannot divine.

The whole arrangement of a Formicarium, or ant-colony, and all the varied activity of ant-life, are directed to one main purposethe perpetuation and dissemination of the species. Most of the labor which we see performed by the workers has for its end the sustenance and welfare of the young brood, which are helpless grubs. The true females are incapable of attending to the wants of their offspring; and it is on the poor sterile workers, who are denied all the other pleas. ures of maternity, that the entire care devolves. The workers are also the chief ugents in carrying out the different migrations of the culonies, which are of vast importance to the dispersal and consequent prosperity of the species. The successful début of the winged males and f(-males depends likewise on the workers. It is amusing to see the activity and excitement which reign in an ant's nest when the exodus of the winged individuals is taking place. The workers clear tho roads of exit, and show the most lively interest in their departure, although it is highly imprubable that any of them will return to the same colony. The swarming or exodus of the winged males and females of the Sain bu ant takes place in January and February, that is, at the commencement of the rainy stason. They come out in the evening in vast numbers, causing quite a commotion in the streets and lanes. They are of very large size, the female measuring no less than two inches and a quarter in expanse of wing ; the male is not much more than half this size. They are so eagerly preyed upon by insectivorous animals that on the morning after their flight not an individual is to be seen, a few impreguated females alone escaping the slaughter to found new colouies.

At the time of our arrival, Para had not quite recovered from the effects of a series of revolutions, brought about by the hatred which existed between the native Brazilians and the Portuguese ; the former, in the end, calling to their aid the Indian and mixed colored population. The number of inhabitants of the city had decreased, in consequence of these disorders, from 24,500 in 1819 , to 15 , 000 in 1848 . Although the public peace had not been broken for twelve years before the date of our visit, confidence was not yet completely restored, and the Portuguese merchants and tradesmen would nut trust themselves to live at their beautiful countryhouses or rocinhas, which lie embosomed in the luxuriant shady gardens around the city. No progress had been mace in clearing the second-growth forest, which had grown over the once cultivated grounds and now reached the end of all the suburban streets. The place had the aspect of one which had seen better days ; the public buildings, including the pulaces of the President and Bishup, the cathedral, the principal churches and con. vents, all seemed constructed on $u$ scale of 
graudeur far beyond the present requirements of the city. Streets full of extensive private residences, built in the Italian style of architecture, were in a neglected condition, weeds and flourishing young trees grcwing from large cracks in the masonry. The large public squares were overgrown with weeds, and impassable on account of the swampy places which occupied portions of their areas. Cornmerce, however, was now beginning to revive, and before I left the country I saw great improvements, as I shall have to relate toward the conclusion of this narrative.

The province of which Pará is the capital was, at the time I allude to, the most cxtensive in the Brazilian Empire, being about 1560 miles in length from east to west, and about 600 in breadth. Since that datenamely, in 1853-it has been aivided into two by the separation of the Upper Amazons us a distinct province. It formerly constituted a section, capitania, or governorship of the Portuguese colony. Originally it was well peopled by Indians, varying much in social condition according to their tribe, but all exhibiting the same general physical characters, which are those of the Ámerican red man, somewhat modified by long residence in an equatorial forest country. Most of the tribes are now extinct or forgotten, at least those which originally peopled the banks of the main river, their descendants having amalgamated with the white and negro immigrants ; * many still Exist, however, in their original state ou the Upper Amazons and most of the branch rivers. On this account Indians in this province are far more numerous than elsewhere in Brazil, and the Indiun element may be said to prevail in the mongrel population, the negro proportion being much smaller than in South Brazil.

The city is built on the best available site for a port of entry to the Amazons region, and must in time become a vast emporium; for the northern shore of the main river, where alone a rival capital could be founded, is much more difficult of access to vessels, and is besides extremely unhealthy. Although lying so near the equator $\left(1^{\circ} 28^{\prime} \mathrm{s}\right.$. lat.) the climate is not excessively hot. The temperature during three years only once reached $95^{\circ}$ of Fahrenheit. The greatest heat of the day, about 2 P.M., ranges generally between $89^{\circ}$ und $94^{\circ}$; but on the other hand, the air is never couler than $73^{\circ}$, so that a uniformly high temperature exists, and the mean of the year is $81^{\circ}$. North American residents say that the heat is not so oppress-

* The mixed breeds which now form, probably, the greater part of the population have each a distinguishing name. Mameluco denotes the offspring of White with Indian; Mulatto, that of White with Negro; Cafuzo, the mixture of the Indian and Negro; Curiboco, the cross between the Cafuzo and the Indian; Xibaro that between the Cafuzo and Negro. These are seldom, however, well-demarcated. and all shades are seldom, however, well-demarcated, an applied only approximatively. The term Creole is confined to approx sorn in the country. The clvilized Indian is called Tapuyo or Caboclo. ive as it is in summer in New York aud Philadelphia. The humidity is, of course, excessive, but the ruins are not so heavy and continuous in the wet season us in many other tropical climates. The country had for a long time a reputation for extreme salubrity. Since the small-pox in 1819 , which attacked chiefly the Indians, no serious epidemic had visited the province. We were agreeably surprised to find no danger from exposure to the night air or residence in the low swampy lands. A few English residents, who had been established here for twenty or thirty years, looked ulmost as fresh in color as if they had never left their native country. The native women, too, seemed to preserve their good looks and plump condition until late in life. I nowhere ubserved that early decay of appearance in Brazilian ladies, which is said to be so general in the women of North America. Up to 1848 the sulubrity of Purá was quite remarkable for a city lying in the delta of a great river in the middle of the tropics and half surrounded by swamps. It did not much longer enjoy its immunity from epidemics. In 1850 the yellow fever visited the province for the first time, and carried off in s few weeks more than four per cent of the pupulation.

The province of Pará, or as we may now say, the two provinces of Pará and the Amazous, contain an area of 800.000 square miles, the population of which is only about 230,000 , or in the ratio of one person to four square miles! The country is covered with. forests, and the soil fertile in the extreme, even for a tropical country. It is intersected throughout by broad and deep navigable rivers. It is the pride of the Paraenses to call the Amazons the Mediterranean of South America. The colossal stream perhaps deserves the name, for not only have the main river and its principal tributaries an immense expanse of water, bathing the shores of extensive and varied regions, but there is alsu throughout a system of back channels, connected with the main rivers by narrow outlets, and linking together a series of lakes, some of which are fifteen, twenty, and thirty miles in length. The whole Amazons valley is thus covered by a netwurk of navigable waters, furming a vast inland fresh-water sea with endless ramifications, rather than a. river.

I resicied at Pará nearly a year and a half altogether, returning thither and making a stay of a few months after each of my shorter ex. cursions into the interior; until the 6 th of November, 1851, when I started on my long voyage to the Tapajos and the Upper Amazons, which occupied me seven years and a hail.

\section{CHAPTER II. PARÁ.}

The swampy forests of Pará-A Portnguese landed: proprietor-Country house at Nazareth-Life of a. Naturalist under the equator-The drier virgin forests-Magoary-Retired creeks-Aborigines.

AFTER having resided about a fortnight at. 
Mr. Miller's rocinha, we heard of another similar country-house to be let, much better situated for our purpose, in the village of Nazareth, a mile and a half from the city, and close to the forest. The owuer was an uld Portuguese gentleman named Danin, who lived at his tile manufactory at the mouth of the Una, a small river lying two miles below Pará. We resolved to walk to his place through the forest, a distance of three miles, although the road was said to be scarcely passable at this season of the year, and the Una much more easily accessible by boat. We were glad, however, of this early opporvunity of traversing the rich swampy forest, which we had admired so much from the deck of the ship; so, about eleven o'clock one sunny morning, after procuriug the necessary information about the road, we set off in that direction. This part of the forest afterward became one of my best huntinggrounds. I will nurrate the incidents of the walk, giving my first impressions and some remarks on the wonderful vegetation. The forest is very similar on most of the low lands, and therefore one description will do for all.

On leaving the town, we walked along a struight suburban road, constructed above the level of the surrounding land. It had low swampy ground on each side. built upon. however, and containing several spacious rocinhas, which were embowered in magnificent foliage. Leaving the last of these, we arrived ut a part where the lofty forest towered up like a wall, five or six yards from the edge of the path, to the height of, probably, 100 feet. The tree trunks were only seen partially here and there, nearly the whole frontage from ground to suminit being covered with a diversified drapery of creeping plants, all of the most vivid shudes of yreen ; scarcely a flower to be seen, except in some places a solitary scarlet passion-flower, set in the green mantle like a star. The low ground on the borders, between the forest wall and the road, was incumbered with a taugled mass of busby and shrubby vegeta. tiun, among which prickly mimosas were very numerous, covering the other bushes in the same way as brambles do in Englaud. Other dwarf mimosas trailed alung the grnund close to the edge of the road, shrinkiug at the slightest touch of the feet as we pissed by. Cassia-trees, with their elegant vinnate foliage and conspicuous yellow tlow. ers, formed a great proportion of the lower tiees, and arborescent aruns grew in groups around the swampy hollows. Over the whole fluttered a larger number of briiliantlycolured butterflies than we had yet seen; some wholly orange or yellow (Callidryas), others with excessively elonyated wings, sailing horizontally through the air, colored black, and varied with blue, red, and yellow (Heliconii). One magnificent grassy-green species (Colænis Dido) especiully aturacted our attention. Near the ground hovered many other smaller species very sinilar in appearance to those found at home, attracted by the flowers of numerous leguminous and other shrubs. Besides butterilies, there were few other insects except dragon-fies, which were in great numbers, similar in shape to English species, but some of them looking conspicuously different on account of their fiery red colurs.

After stupping a long time to examine and admire, we at length walked onward. The road then usceuded slightly, and the soil and vegetation became siddenly altered in character. The shrubs here were grasses, low sedges and other plants, smaller in foliage than those growing in moist grounds. The forest was second growth, low, consisting of trees which had the general aspect of laurels and other evergreens in our gardens at home: the leaves glossy and dark green. Some of them were elegantly veined and halry (Melastomæ), while many, scattered among the rest, hud smaller foliage (Myrtles). but these were not sufficient to subtract much Erom the general character of the whole.

The sun now, for we had loitered long on the road, was exceedingly powerful. The day was most brilliunt; the sky without a cloud. In fact, it was one of those glorious days which announce the commencement of the dry season. The radiation of heat from the sandy ground was visible by the quivering motion of the air above it. We saw or heard no mummals or birds; a few cattle belunging to an estate down a shady lane were congregated, panting, under a cluster of wide-snreading trees. The very soil was hot to our feet, and we hastened onward to the shade of the forest, which we could see not far ahead. At iength, on entering it, what a relief 1 We found ourselves in a moderately broad pathway or alley, where the branches of the trees crossed overhead and produced a delightful shade.' The woods were at first of recent growth, dense, and utterly impenetrable ; the ground, instead of being cluthed with grass and shrubs as in the woods of Europe, was everywhere carpeted with Lycopodiums (fern-shaped mosses). Gradually the scene became changed. We llescented slightly from an elevated, dry, and sandy area to a low and swampy one ; a cool air breathed on our faces, and a mouldy smell of rotting vegetation greeted us. The trees were now taller, the underwood less dense, and we could obtain glimpses into the wilderness on all sides. The leafy crowns of the trees, scarcely two of which could be seen tngether of the same kind, were now far away above us, in another world as it were. We could only see at times, where there was a break above, the tracery of the foliage aguinst the clear blue sky. Sometimes the leaves were palmate, or of the shape of large outstretched hands; ut others, finely cut or feathery, like the leaves of Mimosæ. Below, the tree-trunks were everywhere linked together by sipos; the woody flexible stems of climbing and creeping trees, whose foliage is far away above, mingled with that of the taller independent trees. Some were twisted in strands like cables, others had thick stems 
contorted in every variety of shape, entwining snake-like round the tree trunks, or form. ing gigantic loops and coils among the larger branches ; others, again, were of zigzag shape, or indented like the steps of a staircase, sweeping from the ground to a giddy height.

It interested me much afterward to find that these climbing trees do not form any particular family. There is no distinct group of plants whose especial habit is to climb, but species of many and the most diverse families, the bulk of whose members are not climbers, seem to have been driven by. circumstances to adopt this habit. There is even a climbing genus of palms (Desmoncus), the species of which are called, in the Tupí language, Jacitára. These have slender, thickly-spined, und tlexuous stems, which twine about the taller trees from one to the other, and grow to an incredible length. The leaves, which have the ordinary pinnate shape characteristic of the family, are emitted from the stems at long intervals, instead of being collected into a dense crown, and have at their tips a number of long recurved spines. These structures are excellent contrivances to enable the trees to secure themselves by in climbing, but they are a great nuisance to the travelier, for they some timcs hang over the pathway, und catch the hat or clothes, dragging off the one or tearing the other as he passes. The number and variety of climbing trees in the Amazons forests are interesting taken in connection with the fact of the very general tendency of the animals also to become climbers.

All the Amazonian, and in fact all South American, monkeys are climbers. There is no group answering to the babouns of the Old World, which live on the ground. The Gallinaceous birds of the country, the representatives of the fowls and pheasants of Asia und Africa, are all adapted by the position of the toes to perch on trees, and it is only on trees, at a great height, that they are to be seen. A genus of Plantigrade Carnivora, allied to the bears (Cercoleptes), found only in the Amazonian forests, is entirely arboreal, and has a tong flexible tail like that of certain monkeys. Many other similar instances could be enumerated, but I will mention only the Geodephaga, or carnivornus ground beetles, a great proportion of whose generu and species in these forest regions are, by the structure of their feet,fitted to live exclusively on the branches and leaves of trees.

Many of the woody lianas suspended from trees are not climbers, but the air-roots of epiphytous plants (Aroideæ), which sit on the stronger boughs of the trees above, and hang down straight as plumb-lines. Some are suspended singly, others in clusters ; some reach half way to the ground and others touch it, striking their rootlets intc the earth. The underwood in this part of the forest was com. posed partly of younger trees of the same species as their taller neighbors, and partly of palms of many species, sume of them twenty to thirty feet in height, others small and del- icate, with stems no thicker than a finger. These latter (different kinds of Bactris) bore: small bunches of fruit, red or black, often containing a sweet grape-like juice.

Further on the ground became more swampy, and we had some difficulty in picking our way. The wild banana (Urania Amazonica) heie began to appear, and, as it grew in masses, imparted a new aspect to the scene. The leaves of this beantiful plant are like broad sword-blades, eight feet in length and a foot broad ; they rise straight upward, alternately, from the top of a stem five or six feet high. Numerous kinds of plauts with leaves similar in shape to these, but smaller, clothed the ground. Among them were species of Marantaceæ, some of which had broad glossy leaves, with long leaf-stalks radiatıng from joints in a reed-like stem. The trunks of the trees were clothed with climbing ferns, and Pothos plants with large, fleshy, beait. shaped leaves. Bamboos and other tall grass: and reed-like plants arched over the path way. The appearance of this part of the forest was strange in the extreme; description can convey no adequate idea of it. The reader who has visited Kew may form some notion by conceiving a vegetation like that in the great palm-house spread over a large tract of swampy ground, but he must fancy it mingled with jarge exogenous trees similar to: our oaks and elms covered with ereepers and parasites, and figure to himself the ground incumbered with fallen and rotten trunks, branches, and leaves; the whole illuminate? by a glowing vertical sun, and reeking with moisture.

We at length emerged from the forest, on the banks of the Una, near its mouth. It was here about one hundred yards wide. The residence of Senhor Danin stood on the opposite shore; a large building, whitewashed: and red-tiled as usual, raised on wooden piles: above the humid ground. The second story was the part occupied by the family, and along it was an open veranda, where people, male und female, were at work. Below were several negroes employed carrying clay on. their heads. We cal!ed out for a boat, and one of them erossed over to fetch us. Senhor Danin received us with the usual formal politeness of the Portuguese; he spoke: English very well, and after we had arranged our business we remained conversing with him on various subjects connected with the: country. Like all employers in this province, he was full of one topic-the searcity of hands. It appeared that he had madegreat exertions to introduce white lubor, but had failed, after having brought numbers of men from Portugal and other countries under engagement to work for him. They alt left him one by one soon after their arrivul. The abundance of unoccupied land, the liberty that exists, a state of things produced by the half-wild canoe-life of the people, and the ease with which a mere subsistence can be obtained with moderate work, tempt even the best-disposed to quit regular labor as soun us they can. 
Shortly afterward we took possession of our new residence. The house was a square building, consisting of four equal-sized soums; the tiled roof projected all round, so as to form $\boldsymbol{u}$ broad veranda, cool and pleassut to sit and work jn. The cultivated gicurd, which appeaied as if newly cloared from the forest, was planted with fruit trees and suall plots of coffee and mandi ca. The entrance to the grounds was by an iron-grille gateway from a grassy square, around which were built the few houses and palm-thatched huts which then constituted the village. The must important building was the cisapel of our Lady of Nazareth, which sluod opposite vur place. The saint here enshined was a yreat favorite with all orthodox Paraenses, who attributed to her the performance of many miracles. The image was to be seen on the altar, a handsome doll about four feet high, wearing a silver crown and a garment of hlue silk studded with golden stars. In and about the chapel were the offerings that had been made to her, pronfs of the miracles which she had performed. There were models of legs, arms, breasts, and so forth. which she had cured. But most curious of all was a ship's koar, depusited here by the crew of \& Portuguese vessel which had foundered, a year or two before our arrival, in a squall uff Cayenne; part of them having been sared in the boat, after invoking the protection of the saint here enshrined The annual testival in bonor of our Lady of Nazareth is the gieatest of the Pará holidays ; many persons come to it from the neighboring city of Maranham, 300 miles distant. Once the Presideut ordered the mail steamer to be delayed two days at Pará for the convenience of these visitors. The popularity of the festu is partly owing to the beuutiful weather that prevails when it takes place, namelv, in the middle of the fine season, on the ten days preceding the full monn in October or November. Para is then seen at its best. The weather is not ton dry, for three weeks never follow in succession without a shower: so that an the glory of verdure and flowers can be enjoyed with clear skies. The moonlit vights are then especially beautiful; the Htmosphere is transparently clear, und the light sea breeze produces an agreeable coolniss.

We now settled ourselves for a few minths' regular work. We had the forest on three sides of us; it was the end of the wet season; most species of birds laad finished moulting. and evcry day the insects increased in number and variety. Belind the rociuha, after several days' exploration, I found a series of pathways through the woods, which led to the Una road; about half way was the house in which the celebrated travellers Spix and Martius resided during their stay at Pará. in 1819. It was now in a neglected concition, and the plantations were overgrown with bushes. The paths hereabuut were very productive of insects, and being entirely under shade were very pleasant for strolling. Close to the doors began the main forest road. It wus broad enough for two horsernen abreast, and branched off in three directions; the muin line going to the village of Ourem. a distance of 50 miles. This road formeily extended to Maranham, but it had been long in disuse, and was now grown up, being scarcely passable between Pará and Ourem.

Our researches were made in various directions along these paths, and every day produced us a number of new and interesting species. Cullecting, preparing our specimens, and making notes, kept us well occupied. One dav was so much like another that a general description of the diurual round of incidents, including the sfquence of natural phenomena, will ve sufficient to give an idea of how days pass to naturalists under the equator.

We used to rise soon after dawn, when Isidoro would go dow to the city, after supplying us with a cup of coffee, to purchase the fresh provisious for the day. The two hours before breakfast were devoted to ornithology. At that early period of the day the sky was invariably cloudless (the thermometer marking $72^{\circ}$ or $73^{\circ}$ Fahr.) ; the heavy dew or the previous nigh!'s rain, which lay on the moist foliage, becoming quickly dissipated by the glowing sun, which rising straight out of the east, mounted rapidly toward the zenith. All nature was fresh, new leaf and flower-kudsexpanding rapidly. Some mornings a single tree would appear in flower amid what was the preceding evening a uniform green mass of forest-a dome of blossom suddenly created as if by magic. The birds were all active; from the wild-fruit trees, not far off, we of ten heard the shrill yelping of the Toucans (Ramphastos vitellinus). Small flocks of parrots flew over on most mornings, at a great height, appearing in distinct relief against the blue sky, always two by two, chattering to each other, the pairs being separated by regular intervals; their bright colors, however, were not apparent ai that height. After breakfast we devoted the hours from 10 A.M. to 2 or 3 P.M. to entomolngy; the best time for insects in the forest being a little before the greatest heat of the day.

The heat increased rapidly toward two o'clock $\left(92^{\circ}\right.$ and $93^{\circ}$ Fahr.), by which time every voice of bird or mammal was hushed; only in the trees was heard at intervals the harsh whirr of a cicada. The leaves, which were so moist and fresh in early morning. now become lax and drooping; the flowers shed their petals. Our neighbors, the Indian and mulatto inhabitants of the open pa!mthatched huts, as we returned home fatigued with our ramble, were either asleep in their hammocks or seated on mats in the shade, too languid even to talk. On most days in June and July a heavy shower would fall some time in the afternoon, producing a most welcone coolness. The approach of the rain-clouds was after a uniform fashion very interesting to observe. First, the cool sea-breeze, which commenced to blow about 
ten o'clock, and which had increased in force with the increasing power of the sun, would flag and finally die away. The heat and electric tension of the atmosphere would then become almost insupportable. Languor and uneasiness would seize on every one; even the denizens of the forest betraying it by their motions. White clouds would appear in the east and gather into cumuli, with an increasing blackness along their lower portions. The whole eastern horizon would become almest suddenly black, and this would spread upward, the sun at length becuming obscured. Then the rush of a mighty wind is heard through the forest, swaying the treetops ; a vivid flash of lightning bursts forth, then a crash of thunder, and down streams the deluging iain. Such sturms soon cease, leaving bluish-black motionless clouds in the sky until night. Meantime all nature is refreshed ; but heaps of flower-petals and fallen leaves are seen under the trees. Toward evening life revives again, and the ringing uproar is resumed from bush and tree. The following morning the sun again rises in a cloudless sky, and so the cycle is completed; spring, summer, and autumn, as it were, in one tropical day. The days are more or less like this throughout the year in this country. A little difference exists between the dry aud wet seasons ; but generally, the dry season, which lasts from July to December, is varied with showers, and the wet, from January to June, with sunny days. It results from this that the periodical phenomena of plants und animals co not take place at about the same time in all species, or in the individuals of any given species, as they do in temperate countries. Of course there is no hibernation; nor, as the dry season is not excessive, is there any summer torpidity as in some tropical countries. Plants do not flowc: or shed their leaves, nor do birds moult, pair, or breed simultaneously: In Europe, a woudland scene has its spring, its summer, its autumnal, and its winter aspects. In the equatorial forests the aspect is the same or nearly so every day in the year: budding, flowering, fruiting, and leaf shedding are al ways going on in one species or other. The activity of birds and insects proceeds without interruption, each species having its own separate times; the colonies of wasps, for instance, do not die off annually, leaving unly the queens, as in cold climates; but the succession of generations and culonies gues on incessantly. It is never either spring, summer, or autumn, but each day is a combination of all three. With the day and night always of equal length, the atinospheric disturbances of each day neutralizing themselves before each succeeding morn; with the sun in its course proceeding midway across the sky, and the daily temperature the same within two or three degrees throughout the year-how grand in its perfect equilibrium and simplicity is the march of Nature under the equator!

Our evenings were generally fully employed preserving our collections and muk-
Ing notes. We dined at four, and took tea. about seven o'clock. Sometimes we walked to the city to see Brazilian life or enjuy the pleasures of European and Americau soricty. And so the time passed away from June $151 \mathrm{i}$. to August 26th. During this peri $d$ we. made two excursions of greater length to the rice and saw-mills of Magoary, an establishment owned by an American gentleman, Mr. Upton, situited on the banks of a creek in the heart of the forest, about twelve miles. from Pará. I will narrate some ot the incidents of these excursions, and give an account of the more interesting observations made on the natural history and inhabitauls. of these interior creeks and furests.

Our first trip to the mills was by land. The creek on whose banks they staud, the Iritirí, communicates with the river Pará. through anuther larger creek, the Maguary:so that there is a passage by water, but thisis about twenty miles round. We started at sunrise, taking Isidoro with us. The road. plunged at once into the forest after lcaving. Nazareth, so that in a few minutes we were enveloped in shade. For some distance the woods were of second growth, the originat forest near the town having been formerly cleared or thinned. They were dense anit impenetrable nn account of the close growth: of the young trees and the mass of thornv shrubs and creepers. These thickets swarmei with ants and ant-thrushes: they wese also frequented by a species of puff-throaterl manikin, a little bird which flies occasionally across the road, emitting a strange noise, made, I believc, with the wirgs, and resembling the clatter of a small wooden rattle.

A mile or a mile and a half further on, the character of the woods began to change, and we then found ourselves in the primeval forest. The appearance was greatly different from that of ine swampy tract I have aireacy described. The land was rather nuore elevated and undulading; the many swamp plants with their long and broad leaves were wanting, and there was less underwond, although the trees were wider apart. Througl this wilderness the road continued for seven or eight miles. The same unbroken forest extends all the way to Maranham and in cther directions, as we were told, a distance of about 300 miles southward and eastward of Pará. In almost every hollow part the roau was crossed by a brook, whose cold, dalk, leaf-stained waters were bridged over by ticetrunks. The ground was carpeted, as usual, by Lycopodiums, but it was also incumber ed with masses of vegetable débris and a thicks coating of dead leaves. Fruits of many kinds: were scattered about, among which were: many sorts of beans, some of the pods a foot long, flat and leathery in texture, others hard as stone. In one place there was a quantity of large empty wooden vessels, which Isidura told us fell from the Sapucaya tree. They are called monkeys' drinking-cups (Cuyas de Maccan), and are the capsules which contain the ints sold under the names just mentioned, in Covent Gurden Market. At the top of the 
vessel is a circular hole, in which a natural lid fits neatly. When the nuts are ripe, this da becomes loosened, and the heavy cup falls with a crash, scattering the nuts over the ground. The tree which yields the nut (Lecythis ollaria), is of immense height. It is closely allied to the Brazil-nut tree (Bertholletir excelsa), whose seeds are also inclosed in large woody vessels; but these have no lid, and fall entire to the ground. This is the reason why the one kind of nut is so much dearer than the other. The Sapucaya is not less abundant, probably, than the Bertholletia, but its nuts in falling are scattered about and eaten by wild animals; while the full capsules of Brazil-nuts are collected entire by the nutives.

What attracted us chiefly were the colossal trees. The general run of trees had not remarkably thick stems; the great and uniform height to which they grow without emitting a branch was a much more noticeable feature than their thickness; but at intervals of a furlong or so a veritable giant towered up. Only one of these monstrous trees can grow within a given space ; it monopolizes the domain, and none but individuals of much inferior size can find a footing near it. The cylindrical trunks of these larger trees were generally about 20 to 25 feet in circumference. Von Martius mentions having measured trees in the Pará district, belonging to various species (Symphonia coccinea, Lecy this sp. and Cratæra Tapia), which were 50 to 60 feet in girth at the point where they become cylindrical. The height of the vast column-like stens could not be less than 100 feet from the ground to their lowest branch. Mr. Leavens, at the saw-mills, told me they frequently squared logs for sawing 100 feet long, of the Pao d'Arco and the Massaranduba. The total height of these trees, stem and crown together, may be estimated at from 180 to 200 feet : where one of them stands. the vast dome of foliage rises above the other forest trees as a domed cathedrul does above the other buildings in a city.

A very remarkable feature in these trees is the growth of buttress-shaped projections around the lower purt of their stems. The spaces between these buttresses, which are generally thin walls of wood, form spacious chambers, and may be compared to stalls in a stable : some of them are large enough to hold half a dozen persons. The purpose of these structures is as obvious, at the first glance, as that of the similar props of brickwork which support a high wall. They are not peculiar to one species, but are common to most of the larger forest trees. Their natire and manner of growth are explained when a series of young trees of different ages is examined. It is then seen that they are the roots which have raised themselves ridge-like out of the earth; yrowing gradually upward as the increasing height of the tree sequired augmented support. Thus they ure pluiuly intended to sustain the mussive crown and trunk in these crowded forests, where lateral grow th of the roots in the earth is rendered difficult by the inultitude of com. petitors.

The other grand forcst trees whose nutive names we learned, were the Moira-tinga (the Wuite or King-tree), probahly the same as, or allied to, the Mora excelsa, which Sir Robert Schumbungk discovered in British Guiana; the Samaüma (Eriodendron S:ımauma) and the Massarasduba, or Cow-tsee. The last-mentioned is the most remarkahle. We hud already heard a good deal about this tree, and about its prouucing from its batk a copious supply of milk as pleasant to driık as that of the cow. We had also euten its fruit in Pará, where it is sold in the streets by negro murket woman; and had heard a good deal if the durauleness in water of its timber. We were glad, therefore, to see this wouderful tree growing in its uative wilds. It is one of the largest of the forest monarchs, and is peculiar in appearance on account of its deeply-scored, reudish, and ragged bark. A decoction of the baik, I was told, is used as a red dye for cloth. A few days afterward we tasted its milk, which was drawn frow dry logs that had been stand ing nuany days in the hot sun, at the saw. mills. It w us pleasant with coffee, but had a slight rankness when drank pure; it soon thickens to a glue, which is excessively tenacious, and is often used to cement broken crockery. I was told that it was not safe to drink much of it, for a slare had recently nearly lost his life through taling it too freely.

In some parts of the ruad ferns were conspicuous ubjects. But I afterward found them much more numerous on the Maranham road, especially in une place where the whole forest glade formed a vast fernery; the ground was covered with terrestrial species, and the tree-trunks clothed with climbing and epiphytous kinds. I saw no tree ferns in the Pará district ; they belong to hilly regions; sume occur, however, on the Jpper Amazons.

Such were the principal features in the vegetution of the wilderness; but where were the flowers? To our great disappointment we saw none, or only such as were insignificant in appearance. Orchids are very rare in the dense forests of the low lands. I be, lieve it is now tolerably well ascertained that the majority of forest trees in equatorial Bra. zil have small and inconspicuous flowers. Flower-frequenting insects are also rare in the forest. Of course they would not be found where their favorite food was wanting, but $I$ always noticed that even where Howers occurred in the forest, few or no insects were seen upon them. In the open country or campos of Santarem, on the Lower Amazuns, flowering trees and bushes are more abundant, and there a large num. ber of floral insects are attructed. The forest bees of South America belonging to the genera Melipona and Euglossa ure more fre. quently seen feeding on the sweet sap which exudes from the trees, or on the excrement 
of bir ls on leaves, than on flowers.

We were disappointed also in not meeting with any of the larger animals in the furest. There was no tumultuous movement, or sound of life. We did not see or hear monkeys, and no tapir or jaguar crossed our path. Birds, also, uppeared to be exceedingly scarce. We heard, however, occasionally the long-drawn, wailing note of the Inambú, a kind of partridge (Crypturus cinereus?); and, also, in the hollows on the banks of the rivulets, the noisy notes of another bird, which seemed to go in pairs, among the tree-tops, calling to each other as they went. These notes resounded through the wilderness. Another solitary bird had a most sweet and melancholy song ; it consisted simply of a few notes, uttered in a plaintive key, commencing high, and descending by harmonic intervals. It was probably a spe. cies of warbler of the genus Trishas. All these notes of birds are very striking and characteristic of the forest.

I afterward saw reason to modify my opinion, founded on these first impressions, with regard to the amount aud variety of animal life in this and other parts of the Amazonian forests. There is, in fact, a great variety of mammals, birds, and reptiles, but they are widely scattered, and all excessively shy of man. The region is so extensive, and uniform in the forest clothing of the surface, that it is only at long intervals that animals are seen in abundance, where some particu. lar spot is found which is more attractive than others. Brazil, moreover, is throughout poor in terrestrial mammals, and the species are of small size; they do not, therefore, form a conspicuous feature in its forests. The huntsman would be disappointed who expected to find here flocks of animals similar to the buffalo herds of North America, or the swarms of antelopes and herds of ponderous pachyderms of Southern Africa. The largest and most interesting portion of the Brazilian mammal fauna is arboreal in its habits ; this feature of the animal denizens of these forests I have already alluded to. The most intensely arboreal animals in the world are the South American monkeys of the family Cebidæ, many of which have a fifth hand for climbing in their prehensile tails, adapted for this function by their strong muscular development, and the nuked palms under their tips. This seems to teach us that the South American fauna has been slowly adapted to a forest life, and, therefore, that extensive forests must have always existed since the region was first peopled by mammalia. But to this subject, and to the natural history of the monkeys, of which thirtyeight species inhabit the Amazon region, I shall have to return.

We often read, in books of travels, of the silence and gloom of the Brazilian forests. They are realities, und the impression deepens on a longer acquaiutance. The few sounds of birds are of that pensive or mysterious character which intensifies the feel. ing of solitude rather than imparts a sense of life and cheerfulness. Sometimes, in the midst of the stillness, a sudden yell or scream will startle one; this comes from some de. fenceless fruit-eating animal, which is pounced upon by a tiger-cut or stealthy boa. constrictor. Morning and eveniug the howling monkeys make a most fearful und harrow. ing noise, under which it is difficult to keep up one's buoyancy of spirit. The feeling of inhospitable wildness which the forest is calculated to inspire is increased tenfold under this fearful uproar. Often, even in the still hours of midulay, a sudden crash will be heard resounding nfar through the wilderness, as some great bough or entire tree falls to the ground. There are, besides, many sounds which it is impossibe to account for. I found the natives generally as much at a loss in this respect as myself. Sometimes a sound is heara. like the clang of an iron bar against a hard, hollow tree, or a piercing cry rends the air; these are not repeated, and the succeeding silence tends to heighten the unpleasant impression which they make on the mind. With the native it, is always the Curupira, the wild man or spirit of the forest, which produces all noises they ure unable to explain. Fur myths are the rude theories which mankind, in the infancy of knowledge, invent to explain natural phenomena. The Curupira is a mysterious being, whose attributes are uncertain, fur they vary according to locality. Sometimes he is described as a kind of orang-otang, being covered with long shaggy hair, and living in trees. At uthers he is said to have cloven feet and a bright red face. He has a wife and children, and sometimes comes down to the recas to steal the mandicca. At one time I had a mameluco youtb in my service. whose head was full of the legends and superstitions of the country. He always went with me into the forest ; in fact, I conld not get him to go aloue, and whenever we heard any of the strange noises mentioned above, he used to tremble with fear. He would crouch down behind me, and beg of me to turn back; his alarm ceasing only after he had made a churm to protect us from the Curupíra. For this purpose he took a young palm-leaf, pluited it, and formed it into a ring, which he hung to a branch on our track. At length, after a six hours' walk, we arrived at our destination, the last mile or two hav. ing been again through second-yrowth forest. The mills formed a large pile of build. ings, pleasuntly situated in a cleared tract of land, many acres in extent, and everywhere surrcunded liy the perpeiuu! forcst. We were received in the kindest manner by the overseer, Mr. Leavens, who showed us all that was interesting about the place, and took us to the best spots in the neighborhnod for birds and insects. The mills were built a long time ago by a wealthy Brazilian. They had belonged to Mr. Upton for many years. I was told that when the dark-skinned revolutionists were preparing for their attack on Pará, they occupied the place, but not the slightest injury was done to the machinery or building, for the leaders said it was against
the Portuguese and their party that they were 
at war, not against the other foreigners.

The creek Iritiri at the mills is only a few yards wiaje; it winds about between two lofty walls of forest for some distance, then becomes much broader, and finally juins the Magoary. There are many other ramifications, creeks or channels, which lead to retired hamiets and scatter ed houses, inhabited by people of mixed white. Indian, and negro descent. Many of them did business with Mr. Leavens, bringing tor sale their little harvests of rice or a few logs of timber. It was interesting to see them in their little heavily - laden montarias. Sometimes the boats were managed by handsome, healthy young lads, loosely clad in straw hat, white shirt, and dark blue trousers turned up to the knee. They steered, paddled, and managed the varejao (the boating pole) with much grace and dexterity.

We made many excursions down the Iritirí, and saw much of these creeks; besides, our second visit to the mills was by water. The Maguary is a maguificent channel ; the different branches form quite a labyrinth, and the land is everywhere of little elevation. All these smaller rivers throughout the Para estuary are of the nature of creeks. The land is so level that the short local rivers have no sources and duwnward currents, like rivers as we gencrally uuderstand them. They serve the purpose of draining the land, but instead of having a constant current one way, they have a regular ebb and flow with the tide. The natives call them, in the Tupi language, Igarapés, or canoe-paths. The igarapés and furos or channels, which are infinite in number in this great river delta, are characteristic of the country. The land is everywhere covered with impenetrable forests; the houses and villages are all on the waterside, and nearly all communication is by water. This semi-aquatic life of the people is one of the most interesting features of the country. For short excursions, and for fishing in still waters, a small boat, called moutaiia, is universally used. It is made of five planks; a broad one for the bottom, bent into the proper shape by the action of heat, two narrow ones for the sides, and two small triangular pieces for stem and stern. It has no rudder; the paddle serves for both steering und propelling. The montaria takes here the place of the horse, mule, or camel of other regions. Besides one or more montarias, almost every family has a larger canoe, called Igarite. This is fitted with two masts, a rudder, and keel, and has an arched awning or cabin near the stern, made of a framewurk of tough lianas, thatched with palm-leaves. In the igarite they will cross stormy rivers fifteen or twenty miles broad. The natives are all boat-builders. It is often remaiked, by white residents, that an Indian is a carpenter and shipwright by intuition. It is astonishing to see in what crazy vessels these people will risk themselves. I have seen Indians cross rivers in a leaky monturia, when it required the nicest equilibrium to keep the leak just above water; a novement of a hair's breadth would send all to the bottom, but they managed to cross in safety. They are especially careful when they have strangers under their charge, and it is the custom of Brazilian and Purtuguese travellers to leave the whole management to them. When they are alone, they are more rick. less, and often have to swim for their lives. If a squall overtakes them as they \&re cios: ing in a heavily-laden cauoe, they all jump) overboard and swim about until the hei.vy sea subsides, when they re-embark.

A few words on the aboriginal population of the Pará estuary will here not be out of place. The banks of the Pará were originally inhabited by a number of distinct tribes, who, in their habits, resembled rery nuch the natives of the sea-coast from Marunham to Bahia. It is related that one large tribe, the Tupinambas, migrated from Pernambuco to the Amazons. One fuct seems to be well establisbed, namely, that all the coast tribes were far more advanced in civilization, and milder in their manners, than the savages who inhabited the interior lands of Brazil. They were settled in villages, and addicted to agriculture. They naviguted the rivers in iaríge canoes, called ubás, made of immense boilowed-out tree trunks; in these they used to go on war expeditions, carrying in the prows their trophies and calabash rattles, whose clatter was meant to intimidate their enemies. They were gentle in disposition, and received the early Portuguese settlers with great friendliness. The iuland savages, on the other hand, led a wandering life, as they do at the present time, only coming down occasionally to rob the pluntations of the coast trihes, who always entertained the greatest enmity toward them.

The original Indian tribes of the district are now either civilized or have amalgumated with the white and negro immigrants. Their distinguished tribal names have long been forgotten, and the race bears now the general appellation of Tapuyo, which seems to be one of the names of the ancient Tupinambas. The Indians of the interior, still remaining in the savage state, are called by the Brazilians Indios, or Gentios (Heathens). All the semi- civilized Tapuyos of the villages, and in fuct the inhabitants of retired places generally, sprak the Lingoa geral, a languuge adapted by the Jesuit missionaries from the original idium of the Tupinambas. The language of the Guaranis, a nation living on the banks of the Paraguay, is a dialect of it, and hence it is called by philologists the TupiGuarani language; printed grammars of it are always on sale at the shops of the Pará booksellers. The fact of one language hav. ing been spoken uver so wide an extent of country as that from the Amrzons to Paraguay, is quite an isolated one in this country, und points to considerable migrations of the Indian tribes in former times. At present the languages spoken by neighboring tribe on the banks of the interior rivers are totully distinct ; on the Juruk, even scattered hordew 


\section{NATURALIST ON THE RIVER AMAZONS.}

belonging to the same tribe are not able to understund each other.

The civilized Tapuyo of Pará differs in no essential point, in physical or moral qualities, from the Indian of the interior. He is more stoutly built, being better fed than some of them; but in this respect there are great differences among the tribes themselves. $\mathrm{He}$ presents all the chief characteristics of the American red man. The skin of a coppery brown color, the features of the face broad, and the hair black, whick, and straight. He is generally about the midadle height, thick-set, has a broad inuscular chest, well-shaped but somewhat thick legs and arms, and small hands and feet. The cheek bones ure not generully prominent ; the eyes are black, and seldom oblique like those of the T'artar races of Eastern Asia, which are supposed to have sprung from the same original stock as the American red man. The features exhibit scarcely any mobility of expression ; this is connected with the excessively apathetic and undemonstrative character of the ruce. They never betray, in fact they do not feel keenly, the emotions of joy, grief, wonder, fear, and so forth. They can never be excited to enthusiasm ; but they have strong affections, especially those connected with family. It is commonly stated by the whites and negroes that the Tapuyo is ungruteful. Braziliun mistresses of households, who have much experience of Indians, have always a long list of instances to relate to the stranger, showing their base ingratitude. They certainly do not appear to remember or think of repaying benefits, but this is probably because they did not require, und do not value, such benefits as their would-be masters confer upon them. I have known instances of attachment and fidelity on the part of Indiuns toward their masters, but these ure exceptional cases. All the actions of the Indian show that his ruling desire is to be let alone; he is attached to his home, his quiet monotonous forest and river life; he likes to go to towns occusionaily, to see the wonders introduced by the white man, but he has a great repugnance to living in the midst of the crowd; he prefers handicraft to field labor, and especiully dislikes binding himself to reg. ular labor for hire. He is shy and uneasy before strangers, but if they visit his abode, he treats them well, for he has a rooted ap. preciation of the duty of hospitality ; there is a pride about him, and being naturally formal and polite, he acts the host with great dignity. He withdraws from towns as soon as the stir of civilization begins to make itself felt. When we first arrived at Purá, many Indiun families resided there, for the mode of living at that time was more like that of a lurge village than a city ; but as soon as river stearners und more business activity were introduced, they all gradually took themselves away.

These characteristics of the Pasd Indians are applicable, of course, to some extent, to the Mamelucos, who now constitute a great proportion of the population. The inflexi. bility of character of the Indian, and his tota inability to accommodate himself to new arrangements, will infallibly lead to his extinction, as immigrants, endowed with mure supple organizations, increase, and civilization advances in the Amazon region. But, as the different races amalgamate readily, and the offspring of white and Indian often become distinguished Brazilian citizens, there is little reason to regret the fate of the race. Formerly the Indian was hurshly treated, and even now he is so in many parts of the interior. But, according to the laws of Brazil, he is a free citizen, having equal privileges with the whites; and there are very strong enactments providing against the enslaving and ill-treatment of the Indians. The residents of the interior, who have no higher principles to counteract instinctive selfishness or antipathy of race, cannot comprehend why they are not allowed to compel Indians to work for them, seeing that they will not do it of their own accord. The inevitable result of the conflict of interests between a European and a weaker indigenous race, when the two come in contact, is the sacrifice of the latter. In the Para district, the Indians are no longer ensluved, but they are deprived of their lands, and this they feel bitterly, as one of them, an industrious and worthy man, related to me.

On our second visit to the mills we stajed ten days. There is a large reservoir and also a natural lake near the place, both containing aquatic plants, whose leaves rest on the surface like our water.lilies, but they are not so elegant as our nymphæa, either in leaf or flower. On the banks of these pools grow quantities of a species of fan-leaved palm. tree, the Caraná, whose stems are surrounded by whorls of strong spines. I sometimes took a montaria and paddled myself alune down the creek. One day I got upset, und haci to land on a grassy slope leading to an old plantation, wher I ran about naked while my clothes were being dried on a bush. The creek Iritiri is not so picturesque as many others which I subsequently explored. Toward the Magoary the banks at the edge of the water are clothed with mangrove bushes, and beneath them the muddy banks, into which the long roots that hang down from the fruit before it leaves the brunches strike their fibres, swarm with crabs. On the lower branches the beautiful bird, Ardea helias, is found. This is a small heron of exquisitely graceful shape and mien; its plumage is minutely variegated with bars and spots of muny colors, like the wings of certain kinds of moths. It is difficult to see the bird in the woods, on account of its sombre colors and the shadiness of its dwellingplaces; but its nute, a soft long-drawn whistle, often betrays its hiding-place. I was told by the Indians that it builds in trees, and that the nest, which is made of clay, is beautifully constructed. It is a fávorite pethird of the Brazilians, who call it Pavus - innounced pavaong), or peacock. I often 
had opportunities of nhserving its habits. It soon becomes tame, and walks about the floors of houses, picking up scrups of food, or catching insects, which it secures by walk. ing gently to the place where they settle, ard spearing them with its long slender beak. It allows itself to be handled by children, and will answer to its name, "Puvaó I Pavaó !" walking up with a dainty, circumspect gait, and taking a fly or beetle from the hand.

During these rambles by land and water we increased our collections considerably. Before we left the mills we arranged a joint excursion to the Tocantins. Mr. Leavens wished to ascend that river to ascertain if the reports were true, that cedur grew abundantly between the lowermost cataract and the mouth of the Araguaya, and we agreed to accompany him. While we were at the mills, a Portuguese trader arrived with a quantity of worm-eaten logs of this cedar, which he had gathered from the floating timber in the current of the main Amazons. The tree pro. ducing this woud, which is named cedar on account of the similarity of its aroma to that of the true cedars, is not, of course, a cuniferous tree, as no member of that class is found in equatorial America, at least in the Amazons region. It is, according to Von Martius, the Cedrela odorata, an exogen belonging to the same order as the mahogany-tree. The wood is light, and the tree is therefore, on falling into the water, floated down with the river curreuts. It must grow in great quantities somewhere in the interior, to judge frum the number of uprooted trees annually carried to the sca; and as the wood is mucl esteemed for cabinet-work and canoe-building, it is of some importance to learn where a regular supply can be obtained. We were glad of course to arrange with Mr. Leavens, who was familiar with the language, and an adept in river-navigation; so we returned to Pará to ship our collections for England, and prepare for the journey to a new region.

\section{CHAPTER III.}

PARÁ.

Religions holidays-Marmoset monkeys-SerpentsInsects.

Before leuving the subject of Pará, where 1 resided, as already stated, in all eighteen months, it will be necessary to give a more uetailed account of several matters connected with the customs of the people and the naturai history of the neighborhood, which have bitherto been only briefly mentioned. I reserve an account of the trade and improved condition of Pará in $\mathbf{1 8 5 9}$ for the end of this narrative.

During the first few weeks of our stay many of those religious festivals took place, which occupied so large a share of the time and thoughts of the people. These were splendid affairs, wherein artistically-arranged processions through the streets, accompanied by thousands of people, military displays, the clatter of fireworks, and the clang of military music, were superadded to pomp- ous religious services in t's churches. To those who had witnessed similar ceremunies in the southern countries of Europe, there would be nothing remarkable perhaps in these doings, except their taking place aruid the splendors of tropical nature: but to me they were full of novelty, and were besides interesting as exhibiting much that was peculiar in the manners of the people. The festivals celebrate either the anniversaries of events concerning saints, or those of the more important transactions in the life of Christ. To them have been udded, since the Independence, many gala days connected with the events in the Brazilian national history ; but these have all a semireligious character. The holiduys had become so numerous, and interfered so much with trade and industry toward the year 1852 , that the Brazilian Government was obligec to reduce them; obtaining the necessary permission from Rome to abolish several which were of minor importance. Many of those which have been retained are declining in importance since the introduction of ruilways and steamboats, and the increased devotion of the people to commerce; at the time of our arrival, however, they were in full glory. The way they were managed was in this fashion. A general manager or "Juiz" for each festa was elected by lot every year in the vestry of the church, and to him were handed over all the paraphernalia pertaining to the particular festival which he was chosen to manage; the image of the saint, the banners, silver crowns, and so forth. He then employed a number of people to go the round of the parish and collect alms toward defraying the expenses. It was considered that the greater the amount of money spent in wax-candles, fireworks, music and feasting, the greater the honor done to the saint. 'If the Juiz was a rich man, he seldom sent out alms-gatherers, but celebrated the whole affair at his own expense, which was sumetimes to the extent of several hundred pounds Each festival lasted nine days (a novena), and in many cases refreshments for the public were provided every evening. In the smaller towns a ball took place two or three evenings during the novena, and on the last day there was a grand dinner. The priest, of course, had to be paid very liberally, especially for the sermon delivered on the Saint's day or termination of the festivals, sermons being extra duty in Brazil.

There was much difference as to the accessories of these festivals between the interior towns and villages and the cupital ; but little or no work was done anywhere while they lasted, and they tended much to demoralize the people. It is soon perceived that religion is rather the amusement of the Puraenses than their serious exercise. The ideas of the majority evidently do not reach beyond the belief that all the proceedings are, in each case, in hunor of the particular wooden image enshrined at the church. The uneducated Portuguese immigrants seemed to me to have 
very degrading notions of religion. I have often travelled in the company of these shining exumples of European enlightenment. They generally carry with them, wherever they go, a small image of sume favorite saint in their trunks; and when a syuall or any other danger arises, their first impulse is to rush to the cabin, take out the inage and clasp it to their lips, while uttering a prayer for protection. The negroes and mulattoes are similar in this respect to the low Portuguese, but I think they show a purer devotiunal feeling; and in conversation I have always fuund them to be more rational in religious views than the lower orders of Portuguese. As to the Indians, with the exception of the more civilized families residing near the large towns, they exhibit no religious sentiment at all. They have their own patron saint, St. Thomé, and celebrate has anniversary in the orthodox way, for they are fond of observing all the furmaliiies; but they think the feasting to be of equal importance with the church ceremonies. At some of the festivals masquerading forms a large part of the proceedings, and then the Indians really shine. They get up capital imitations of wild unimals, dress themselves to represent the Caypór and other fabulous creatures of the forest, and act their parts throughout with great cleverness. When St. Thomé's festival takes place, every employer of Indians knows that all his men will get drunk. The Indian, generally too shy to ask directly for cashaça (rum), is then very bold; he asks for a frasco at once (two bottles and a half), and says, if interrogated, that he is going to fuddle in honor of St. Thomé.

In the city of Pará, the provincial government assists to uugment the splendur of the religious holidays. The processions which traverse the principal streets consist, in the first place, of the image of the saint, und those of several other subordinate ones belonging to the same church ; these are borne on the shoulders of respectable househulders, who volunteer for the purpose : sometimes you will see your neighbor the grocer or the carpenter groaning under the load. The priest and his crowd of attendants precede the images, arrayed in embroidered robes, and protected by magnificent sunshades-no useless ornament here, for the heat is very great when the sun is not obscured. On each side of the long line the citizens walk, clad in crimson silk cloaks, and holding each a large lighted wax candle. Behind follows a regiment or two of foot soldiers with their bands of music, and last of all the crowd, the colored people being cleanly dressed and preserving a grave demeanor. The women are always in great force, their luxuriant black hair decorated with jasmines, white orchids, and other tropical flowers. They are dressed in their usual holiday attire, gauze chemises and black silk petticoats; their necks are adorned with links of gold beads, which when they are slaves are gencrally the property of their mistresses, who love thus to display their wealth.
At night, when festivals are going on in: the grassy squares around the suburban. churches, there is rually much to admire. A great deal that is peculiar in the land ard the life of its inhabitants can be seen best at those times. The cheerful white church is brilliantly lighted up, and the music, not of a very solemn description, peals furth from the open windows and doors. Numbers of young gaudily-dressed negresses line the path to the church doors with stands of liqueurs, sweetrneats, aud cigarettes, which they sell to the outsiders. A short distance off is heard the rattle of dice-boxes and roulette at the open-air gambling stalls. When the festival happens on moonlit nights, the whole scene is very striking to a new-comer. Around the square are groups of tall palm. trees, and beyond it, over the illuminated houses, appear the thick groves of mangoes near the sul,urban avenues, from which comes the perpetual ringing din of insect life. The soft tropical moonlight lends a wonderful charm to the whule. The inhabitants are all out, dressed in their best. The upper classes, who come to enjoy the fine evening and the general cheerfulness, are seated on chairs around the doors of friendly liouses. Theie is no boisteruas conviviality, but a quiet enjoyment seems to be felt everywhere, and a gentle courtesy rules amoug all classes and colors. I have seen a splendidly dressed colunel, from the President's palace, walk up to a mulatto and politely ask his permission to take a light from his cigar. When the service is over, the church bells are set ringing, a shower of rockets mounts upward, the bands strike up, and parties of colored people in the bouths begin their dances. About ten o'clock the Brazilian national air is played, and all disperse quietly and soberly to their homes.

At the festival of Corpus Christi there was a very pretty arrangement. The large green square of the Trinidade was lighted up all round with bonfires. On one side a fine pavilion was erected, the upright posts consisting of real fan-leaved palm-trees, the Mauritia flexuosa, which had been brought from the forest, stems and heads entire, and fixed in the ground. The buoth was illuminated with colored lamps, and lined with red and white cloth. In it were seated the ladies, not all of pure Caucasian blood, but presenting a fine sample of Pará beauty and fashion.

The grandest of all these festivals is that held in honor of Our Lady of Nazareth : it is, I believe, peculiar to Pará. As I have said before, it falls in the second quarter of the moon, about the middle of the dry stason-that is, in October or November-and lasts, like the others, nine days. On the first day a very extensive procession takes place, starting from the cachedral, whither the image of the saint has been conveyed some days previuusly, and terminating at the chapel or hermitage, as it is called, of the saint at Nazareth, a distance of more than two miles. The whole population turns out on this occasion. All the suldiers, both of: 
the line and the National Guard, take part in it, each battalion accompanied ly its land of music. The civil authorities also, with the President at their head, and the principal citizens, including many of the foreigu residents, join in the line. The boat of the shipwrecked Portuguese vessel is carried after the saint on the shoulders of officers or men of the Brazilian navy, and along with it are borne the other symbuls of the miracles which Our Lady is supposed to have perfurmed. The procession starts soun after the sun's heat begins to moderate-that is, about half-past four o'clock in the afternoon. When the image is deposited in the chapel the festival is considered to be inaugurated, and the village every evening becomes the resort of the pleasure-loving population, the holiday portion of the programme being preceded, of course, hy a religious service in the chapel. The aspect of the place is then that of a fair ; without the humor and fun, but, at the same time, without the noise and coarseness, of similar holidays in England. Large rooms are set apart for panoramic und other exhibitions, to which the public are admitted gratis. In the course of each evening large displays of fireworks take place, all arranged according to a published programme of the festival.

The various ceremonies which take place during Lent seemed to me the most impressive, und some of them were exceedingly well urranged. The people, both performers and spectators, conduct themselves with more gravity on these occasions, and there is no holiday-making. Performances representing the last events in the life of Christ are enacted in the churches or streets, in such a way as to remind one of the old miracle plays or mysteries. A few days before Good Friday, a torchlight procession takes place by night, from one church to another, in which is carried a large wooden image of Christ bent under the weight of the cross. The chief members of the Gov $\epsilon$ rnment assist, and the whole slowly moves to the sound of muffled drums. A double procession is mangyed a few days afterward. The image of Si. Mary is carried in one direction, and that of the Saviour in another. The two images meet in the middle of one of the most beautiful churches, which is previously filled to ex-cess with the multitude anxious to witness the affecting meeting of mother and son a few days before the crucifixion. The images are brought face to face in the middle of the church, the crowd falls prostrate, and the lachrymose sermon is delivered from the pulpit. The whole thing, as well as many other spectacles arranged during the few succeeding days, is highly theatrical, and well calculated to excite the religious cmotions of the people, although, perhaps, only tempo-rarily. On Good Friday the bells do not ring, all musical sounds are intezdicted, and the hours, night and day, are announced by the dismal noise of wooden clappers wielded by negroes stationed near the different churches. A sermon is delivered in each church. In the middle of it, a scroll is suddenly unfolded from the pulpit, on which is an exaggerated picture of the blceding Christ. This act is accompanied by loud groans which come from stuut-lunged individuals concealed in the vestry and engaged for the purpose. The priest becomes greatly excited, and actually sheds tears. On one of these occasions I squeezed myself into the crowd, and watched the effect of the spectacle on the audience. Old Purtuguese men and Brazilian women seemed very much affected-sobbing, beating their breasts, and telling their beads. The negroes behaved themselves with great propriety, but seemed moved more particularly by the pomp, the gilding, the dresses, and the yeneral display. Young Brazilians laughed. Severul aborigines were there, coolly looking on. One old Indian, who was standing near me, said, in a derisive manner, when the sermon was over. "It's all very good ; better it could not be" (Está todo bom ; melhor naō pude ser).

The negroes of Pará are very devout. They have built, by slow degrees, a fine church, as I was told, by their own unaided exertions. It is called Nossa Senhura do Rosario, or Our Lady of the Rosary. During the first weeks of our residence at Pará, 1 frequently observed a line of negroes and negresses, late at night, murching along the streets, singing a chorus. Each carried on his or her head a quantity of building materials-stones, bricks, mortar, or planks. I found they were chiefly slaves, who, after their hard day's work, were contributing a little toward the construction of their church. The materials had all been purchased by their own savings. The interior was finished about a y 3 ar afterward, and is decorated, I thought, quite as superbly as the other churches which were constructed, with far larger means, by the old religious orders more than a century ago. Annually the negrues celebrate the festival of Nossa Senhora do Rosario, und generally make it a complete success.

I will now add a few more notes which I have accumulated on the subject of the natural history, and then we shall have done, for the present, with Pará and its neighborhood.

I have already mentioned that monkeys were rare in the immediate vicinity of Para. I met with three species unly in the forest near the city; they are shy animals, and aroti the neighborhuod of towns, where they are subject to much persecution by the inlabitants, who kill them for foud. The only kind which I saw frequently was the little Midas ursulus, one of the Marmosets, a family peculiar to tropica, A America, and differing in many essentiul points of structure and habits from all other apes. They art small in size, and more like squirrels than true monkeys in their manner of climbing. The nails, except those of the hind thumbs, are long and claw-shaped like those of squirrels, and the thumbs of the fore extremities, 
or hands, are not opposable to the other fingers. I do not mean to imply that they have a near relationship to squirrels, which belong to the Rodents, an inferior order of mammals ; their resemblance to those animals is merely a superficial one. They have two molar teeth less in each jaw than the Cebidx, the other fumily of American munkeys; they agtee with them, however, in the sideway position of the nostrils, a character which distinguishes both from all the monkeys of the old world. The body is long and slender, clothed with soft hairs, and the tail, which is nearly twice the length of the trunk, is not prehensilc. The hind limbs are much larger in volume than the auterior pair. The Midus ursulus is never seen in large flocks ; three or four are the greatest number observed to. gether. It seems to be less afraid of the neighborhood of man than any other mon: key. I sometimes saw it in the woods which border the suburban streets, and once I espied two individuals in a thicket behind the Eng. lish consul's house at Nazareih. Its mode of progression along the main boughs of the lofty trees is like that of the squirrel; it does not ascend to the slender branches, or take those wonderful flying leaps which the Cebidæ do, whose prehensile tails and flexible hands fit them for such headlong travelling. It confines itself to the larger boughs and trunks of trees, the leng nails being of great sissistance to the creature, enabling it to cling securely to the bark; and it is often seen passing rapidly round the perpendicular cylindrical trunks. It is a quick, restless, timid little creature, and has a great share of curiosity, for when a person passes by under the trees along which a flock is running, they always stop for a few moments to have a stare at the intruder. In Pará, Midas ursulus is often seen in a tame state in the houses of the inhabitants. When full grown, it is about nine inches long, independently of the tail, which measures fifteen inches. The fur is thick, and black in color, with the exception of a reddish-brown streak down the middle of the back. When first taken, or when kept tied up, it is very timid and irritable. It will not allow itself to be approached, but keeps retreating backward when any one attempts to coax it. It is always in a querulous humor, uttering a twittering, complaining noise ; its dark, watch. ful eyes, expressive of distrust, observant of every movement which takes place near it. When treated kindly, however, as it generally is in the houses of the natives, it becomes very tame and familiar. I once saw one as playful as a kitten, running about the house after the negro children, who fondled it to their hearts' content. It acted somewhat differently toward strangers, and seemed not to like them to sit in the hammock which was slung in the room, leaping up, trying to bite, and otherwise annoying them. It is senerally fed on sweet fruits, such as the banana; but it is also fond of insects, especially soft-hodied spiders and grusshoppers.

which it will snap up with eagerness whon within reach. The expression of countenance in these small monkeys is intelligent and pleasing. This is partly owing to the open tacial angle, which is given as one of $60^{\circ}$; but the quick movements of the head, and the way they have of inclining it to one side when their curiosity is excited, contribute very much to give them a knowing expression.

On the Upper Amazons I once saw a tame individual of the Midas leoninus, a species first described by Humboldt, which was still more playful and intelligent than the one just described. This rare and beautiful little monkey is only seven inches in length, exclusive of the tail. It is named leonizus on account of the long brown mane which depends from the neck, and which gives it very much the appearance of a diminutive lion. In the house where it was kept it was familiar with every one ; its greatest pleasure seeming to be to climb abuut the bodies of different persons who entered. The first time I went in, it ran across the room straightway to the chair on which I had sat duwn, and climbed up to my shoulder ; arrived there, it turned round and looked into my face, showing its: little teeth, and chattering, as though it would say, "Well, and how do you do?" It showed more affection toward its masterthan toward strangers, and would climb up. to his head a dozen times in the course of an hour, making a great show every time of searching there for certain animalculæ. Isidore Geoffroy St. Hilaire relates of a species of this genus, that it distinguished between different objecis depicted on un engraving. M. Audouin showed it the portraits of a cat. and a wasp; at these it became much terrified : whereas, at the sight of a figure of a grasshopper or beetle, it precipitated itself on the picture, as if to seize the objects there represented.

Although monkeys are now rare in a wild state near Pará, a great number may be seen semi-domesticated in the city. The Brazilians are fond of pet animals. Monkeys, however, have not been known to breed in captivity in this country. I counted, in a short time, thirteen different species, while walking about the Pará streets, either at the doors or windows of houses, or in the native. canoes. Two of them I did not meet with. afterward in any other part of the country. One of these was the well-known Hapale Jacchus, a little creature resembling a kitten, bunded with black and gray all over the body and tail, and having a fringe of long white hairs surrounding the ears. It was seated on the shoulder of a young mulatto girl, as she was walking along the street, and I was. told had been captured in the island of Marajo. The otier was a species of Cebus, with a remarkably large head. It had ruddy-brown fur, paler on the face, but presenting a blackish tuft on the top of the forehead.

In the wet season serpents are common in the neighborhood of Pará. One morning, in April, 1849, after a night of deluging rain, 
the lamplighter, on his rounds to extinguish the lamps, knocked me up to show me a bua-constrictor he had just killed in the Rua St. Antonio, not far from my door. He had cut it nearly in two with a large knife, as it was making its way down the sandy street. Sometimes the native hunters capture boaconstrictors alive in the forest near the city. We bought one which had been taken in this way, and kept it for some time in a laıge box under our veranda. This is not, however, the largest or most formidable seipent fuund in the Amazons regicn. It is far inferior, in these respects, to the hideous Sucuruju, or Wrater Boa (Eunectes marinus), which sometimes attacks man; but of this I shall have to give an account in a subsequent chapter.

It frequently happened, in passing through the thickets, that a snake would fall from the boughs close to me. Once I got for a few moments ccmpletely cntangled in the folds of one, a wonderfully slender kind, being nearly six feet in length, and not more than hulf an inch in diameter at its broadest part. It was a species of Diyophis. The majority of the snalses seen wr re innocuous. One day, however, I trod on the tail of a young selpent belonging to a very poisonous kind, the Jararaca (Craspedoccphalus atrox). It turned round and bit my trousers ; and a young Indian lad, who was bebind me, rexterously cut it through with his knife before it had time to free itself. In scme seasons snakes are rery abundant, und it often struck me as stlange that accidents did not occur more frequently than was the case.

Amcng the most curious snakes found here were the Amphisbænæ, a genus allicd to the slow worm of Europe. Sevelal species occur at Pará. Those brought to we were gonerully not much more than a fcot in lingth. They are of cylindrical shape, having, properly epeaking, no neck; anci the blunt tail, which is only about an inch in length, is of the same shape as the lead. This peculiar form, added to their habit of wriggling backward as well as forward, has given rise to the fable that they have two heads, one at each extremity. They are extremely sluggish in their motions, und are clothed with scales that have the form of small imluedded plates arranget ic rings round the body. The eye is so small as to be scarcely perceptible. They live habitually in the subterranean chambers of the Saüba ant; ouly coming out of their abodes cccasionally in the night time. The natives call the Amphisbana the "Mai das Saübas," or Mother of the Saübas, and believe it to be poisonous, although it is perfectiy harmless. It is one of the many curious animals which hare become the subject of mythical stories with the natives. They bay the ants treat it with great affection, and that if the snake be taken away from a nest, the Saübas will forsake the spot. I once took one quite whole out of the body of a young Jararacu, the poisonous species already alluded to, whose body was so distended with its contents that the skin was stretclied out to a film over the contained Amplisbana. was, unfortunately, not able to ascurtain the exuct relation which subsists between these curious snakes and the Saüba ants. I believe, however, they feed upon the Saübas, for $I$ once found remains of ants in the stomach of one of them. Their motions are quite peculiar; the undilatable jaws, small eyes, and curious plated integument also dis. tinguish them from other snakes. These properties have evidently some relation to their residence in the subterranean abodes of ants. It is now well ascertained by natural. ists, that some of the most anumalous forms among coleopterous insects are those which live solely in the nests of ants, and it is curious that an abnormal form of snakes should also be found in the society of these insects.

The neighborhood of Prrá is rich in insects. I do not speak of the number of individuals, which is probably less than one meets, with, excepting ants and Termites, in summer days in temperate latitudes; but the variety, or in other words, the number of species, is very great. It will convey some idea of the diversity of butterflies when I mention that about $\% 00$ species of that tribe are found within an lour's walk of the town; while the total number found in the British Islands does not exceed 66 , and the whole of Europe supports only 321. Some of the most showy species, such as the swallow-tailed kinds, Papilio Pulycaon, Thous, Torquatus, and others, are seen flying about. the streets and gardens; sometimes they come through the open windows, attracted by flowers in the apartments. Those species of Papilio which are most characteristic of the country, so conspicuous in their velvetyblack, green, and rose-colored hues, which Linnæus, in pursuance of hiś elegant system of nomenelature-niming the different kinds after the heroes of Greek mythology-called Trojans, never leave the shades of the forest. The splendid inetallic blue Murphos, some of which measure seven inches in expanse, are generally confined to the shady valley of the forest. They sometimes come forth into the broad sunlight. When we first went to look at our new residence in Nazareth, a Morpho Menelaus, one of the most beautiful kinds, was seen flapping its huge winds like a bird along the veranda. This species, however, although much admired, looks dull in culor by the side of its congener, the Morpho Rise. tenor, whose wings, on the upper face, are of quite a dazzling lustre. Rhetenor usually prefers the broad sunny roads in the fotest, and is an almost unattainable prize, on account of its lofty flight; for it very rarely descends nearer the ground than about twenty feet. When it comes sailing along, it occusionally faps its wings, and then the blue surface flashes in the sunlight, so that it is visib'e a quarter of a mile off. There is another species of this genus, of a satiny. white hue, the Morpho Uraneis; this is equally difficult to obtain ; the male only has the satiny lustre, the female being of a palelavender color. It is in the height of the dry season that the greatest number and variety 
of butcerflies are found in the woods ; especially when a shower falls at intervals of a few days. An infinite number of curious and rare species may then be taken, most diversified in habits, mode of flight, colors, and markings: some ycllow, others bright red, green, purple, and blue, and many burdered or spangled with metallic lines and spots of a silvery or golden lustre. Some have wings trausparent as glass : one of these clear-wings is especially beautiful, naniely, the Hetæra Esmeralda ; it las one spot only of opaque coloring on its wings, which is of a violet and rose hue; this is the only part visible when the insect is flying low over dead leaves, in the gloomy shades where alone it is found, and it then looks like a wandering petal of a flower.

Bees and wasps are not especially numerous near Pará, and I will reserve an accuunt of their habits for a future chapter. Many species of Mygale, those monstrous hairy spiders, half a font in expause, which attract the attention so much in museums, are found in sandy places at Nazareth. The different kinds have the most diversified habits. Some construct, among the tiles or thatch of houses, dens of closely-woven web, which, in texture, very much resembles fine muslin; these ure often seen crawling over the walls of apartments. Uthers build similar nests in trees, and are known to attack birds. One very robust fellow, the Mygale Blondii, burrows into the earth, forming a broad slanting gallery, about two feet long, the sides of which he lines beautifully with silk. He is nocturnal in his habits. Just before sunset he may be seen keeping watch within the mouth of his tunnel, disappearing suddenly, when he hears a heavy foot-tread near his hiding-place. The number of spiders ornamented with showy colors was somewhat re markable. Some double themselves up at the base of leaf-stalks, so as to resemble finwer-buds, and thus deceive the insects on which they prey. The must extraordinary-looking spider was a species of Acrosoma, which had two curved bronze-colored spines, an inch and $a$ half in length, proceeding from the tip of its abdomen. It spins a large web, the monstrous appendages being apparently $n$ 's inpediment to it in its work; but what their use can be I am unable to divine.

Coleoptera, or beetles, at first seemed to be very scarce. This apparent scarcity has been noticed in other equatorial countries, and arises, probably, from the great heat of the sun not permitting them to exist in exposed situations, where they form such conspicuous objects in Europe. Many hundred species of the different families can be found, when they are patiently searched for in the shady places to which they are confined. It is vain to look for the Geodephaga, or carnivorous beetles, under stones, or anywhere, indeed, in open, sunny places. The terrestrial forms of this interesting family, which abound in England and temperate countries generally, are scarce in the neighborhood of Pará, in fact I met with only four or five species; on the other hand the purely arboreal kinds were rather numerous. The contrary of this happens in northein latitudes, where the great majority of the species and genera are exclusively terrestrial. The arboreal forms are distinguished by the structure of the feet, which have broad spongy soles and toothed claws, enabling thein to climb over and cling to branches and leaves. The remarkable scarcity of ground beetles is, doubtless, attributable to the number of ants and Termites which people every inch of surface in all shady places, and which would most likely destroy the larvæ of Coleoptera. Moreover these active creatures have the same functions as Coleoptera, and thus render their existence unnecessary. The large proportion of climbing forms of carnivorous beetles is an interesting fact, because it affords another instance of the arboreal character which animal forms tend to assume in equinoctial America, a circumstunce which points to the slow adaptation of the Fauna to a forest-clad country, throughout an immense lapse of geolugical time.

\section{CHAPTER IV.}

THE TOCANTINS AND CAMETÁ.

Preparations for the journey-The Bay of GoajaráGrove of fan-leaved palms-The lower Tocantinssketch of the river-Vista alegre-Baiao-RapidsBoat journey to the Guariba Falls-Native life on the Tocuntins-Second journey to Cametá.

August 26th. 1848.-Mr. Wallace and I started to-day on the excursion which 1 have already mentioned as having been plauned with Mr. Leavens, up the river Tocantins, whose mouth lies about forty-five miles in a straight line, but eighty miles following the bends of the river channels, to the south-west of Para. This river, as before stated, has a course of 1600 miles, and stands third in rank among the streams which form the Amazons system. The preparations for the journey took a great deal of time and trouble. We had first to hire a proper vessel, a two-masted vigilinga twenty-seven feet long, with a flat prow and greath breadth of beam, and titted to live in heavy seas ; for although our voyage was only a river trip, there were vast sealike expanses of water to traverse. It was not decked over, but bad two arched awnings formed of strong wickerwork, and thatched with palm-leaves. We had then to store it with provisions for three months, the time we at first intended to be away; procure the necessary passports ; and, lastly, engage a crew. Mr. Leavens, having had much experience in the country, managed all these matters. He brought two Indians from the rice-mills, and these induced another to enroll himself. We, on our parts, took our cook, Isidoro, and a young Indian lad, named Antonio, who had attached himself to us in the course of our residence at Nazareth. Our principal mun was Alexandro, one of $\mathrm{Mr}$. Lravens's Indians. He was an intelligeut and well-disposed young Tapuyo, an expert sailor and an indefatigable hunter. To his fidelity we were indebted for being enabled - to carry out any of the objects of vur voy- 
agc. being a native of a district near the capilal, Alexandro was q civilized Tapuyo, a citizen as free as his white neighbors. He spoke unly Portuguese. He was a sparebuilt man, rather under the iniddle height, with fine regulur features, and, what was unusual in Indians, the upper lip decorated with a mustache. Three years afterward I saw him at Pará in the uniform of the Nationai Guard, and lie called on me often to talk about cld times. I esteemed him as a quiet, sensible, manly young fellow.

We set sait in the evening, after waiting several hours in vain for one of our crew. It was soon da! $\mathrm{k}$, the wind blew stiffly, and the tide rushed along with great rapidity, carrying us swifly past the crowd of vessels which were anchored in the port. The canoe rolled a good deal. After we had made five or six miles of way the tide turned, and we were obliged to cast anchor. Not long after, we laid ourselves down all three together on the nuat, which was spread over the flour of our cabin, and soon fell asleep.

On awaking at sunrise the next morning, we found cuiselves gliding upward with the tide, along the Bahiu or Bay, as it is called, of Goajara. This is a bruad channel lying between the mainland and a line of islands which extend some distance beyond the city. Into it three large rivens dischange their waters, namely, the Guamá, the Acará, and the Mojú; so that it forms a kind of stib. estury within the grandl estualy of Pará. It is neally four miles broad. The left bank, along which we were now sailing, was beau. tiful in the extreme; not an inch of soil was to be secn; the water frcntage piesented a compact wall of rich and varied forest, resting on the surface of the stream. It seemed to form a tinished border to the water scene, where the dome-like, rounded shapes of exogenous trees which constituted the mass formed the groundwork, and the cndless diversity of broad-leaved Heliconix and Palms -each kind differing in stem, crown, and fronds-the rich embroidery. The morning was ealm and cluudless; and the slanting beams of the early sun, striking full on the front of the forest, lighted up the whole most gloriously. The enly sound of life which reached us was the call of the Serracura (Gallinula Cayennensis), a kind of wild fcwl; all clse was so still that the voices of boutmen could he plainly heard, from canoes passing a mile or two distant fiom us. The sun soon gains great power on the water, but with it the sea-bleeze increases in strength, moderating the heat which would otherwise be almost in. supportable. We reached the end of the Goajará about midday, and then (ntered the narruwer channel of the Mojú. Up this we travelled, partly rowing and partly sailing, between the same uubruken walls of forest, until the morning of the 28 th.

August 29th.- The Mojú, a stream little inferior to the Thames in size, is connceted about twenty miles from its mouth, by meaus of a short artificial canal, with a small stream, the Igarapé-mirinı, which fluws the opposite way into the water systen of the: Tocantins. Small ressels like ours take this. ruute in vreference to the stormy passage by way of the main river, although the distance is considerably greater. We passed through the canal yesterday, and to-day have be threading our way through a labyrinth of nal row chaunels, their banks all elothed with the same magnificent forest, but agreenbly varicd by houses of planters and settlers. We passed many quite large establishments, besicles one pretiy little village called Santa Anna. All these channels are washed through by the tides-the ehb, contrary to what takes place in the short canal, setting tuward the Tueantins. The water is almost tepid ( $77^{\circ}$ Fahr.), and the rank vegetation all around seems reeking with moisture. The country, however, as we were told, is perfectly bealthy. Some of the loouses are huile on wouden piles driven into the mud of the swamp.

In the afternoon we reached t!e end of the last channel, called the Murutipucú, which runs for several miles between two unbroken lines of fan-leaved palms, forming with their straight stems colossal palisades. On rounding a point of land we came in full view of the Tocantins. The event was announced by one of our Indians, who was on the look. out at the prow, shouting, " La está o Puranáuassú !" " Behold the great river !" It was a grand sight-a broad expanse of dark waters danciug merrily to the brecze; the oppusite shore, a narrow blue line, miles away.

We went ashore on an island covered with palm-trees, to make a fire and bcil our kettle for tea. I wandered a shout way inland, and was astounded at the prospect. The land lay below the upper level of the daily tides, so that there was no underwood, and the grouni was bare. The trees weie almost all of one species of Palm, the gigantic fanleaved Mauritia flexuosa; on the borders only was there a small number of a secoud kind, the equally remarkable Ubusé palm (Manicaria saccifera). The U bussú has erect, uncut leaves, twenty-five feet long, and six feet wide, all arranged round the top of a fuur-feet high stem, so as to form a figure like that of a colossal shuttlecock. The fan. leaved palms, which clothed nearly the entire islet, had huge cylindrical smooth sic.:s, three fert in diameter, and about a hundred feet high. The crowns were formed of cuor. mous clusters of fan-shaped leaves, the sta!lis alone of which measured seven to tea feet in length. Nothiug; in the vegetuble world could be more imposing than this grove of pulms. There was no underwood tuchsiruct the view of the long perspective of towcriug colurnus. The crowns, which were densely packed tugether at an immense height uverhead, shut out the rays of the sun; and the gloomy solitude beneath, through which the sound of our voices seemed to severberate, could be compared to nothing so well as a solemn temple. The fruits of the two paims were scattered orer the ground ; those of the Ubussa adhere together by twos and threes 
sard $h_{a}$. \& 4 rough, brown-colored shell ; the fruit of the Mauritia, on the contrary, is of a Sright red hue, and the skin is impressed with deep crossing lines, which give is a resemblance to a quilted cricket-ball.

About midnight, the tide being favorable and the breeze strong, we crossed the river, taking it in a slanting direction, a distance of sixteen miles, and arrived at eight $v^{\prime}$ clock the following morning at Cumetá. This is a town of some importance pleasantly situated on the somewhat high terra firma of the left bank of the Tocantins. I will defer giving an account of the place till the end of this narrative of our Tocantins voyage. We lost here another of our men, who got drinking with some old companions ushore, and were nbliged to start on the difficult journey up the river with two hands only, and they in a very dissatisfied humor with the prospect.

The river view from Cametá is magnificent. The town is situated, as already mentioned, on a high bank, which forms quite a considerable elevation for this flat country, and the broad expanse of dark-green waters is studded with low, palm-clad islands; the prospect down river, however, being clear, or bounded only by a sea-like horizon of water and sky. The shores are washed by the breeze-tossed waters into little bays and creeks, fringed with sandly beaches. The Tocantins has been likened, by Prince Adalbert of Prussia, who crossed its mouth in 1846 , to the Ganges. It is upward of ten miles in breadth at its mouth; opposite Cametá it is five miles broad. Mr. Burchell, the well-known English traveller, descended the river from the miniug provinces of in terior Brazil some years before nur visit. Unfortunately, the utility of this fine stream is impaired by the numerous obstructions to its navigation in the shape of cataracts and rapids, which commence, in ascending, at about 120 miles above Cametá, as will be seen in the sequel.

August 30th.-Arrived, in company witb Senhor Laroque, an intelligent Porluguese merchant, at Vista Alegre, fifteen miles above Cametá. This was the residence of Senhor Antonio Ferreira Gomez, and was a fair sample of a Brazilian planter's establishment in this part of the country. The buildings covered a wide space, the dwelling-house being separated from the place of business, and as both were built on low, flooded ground, the communication between the two was by means of a long wooden bridge. From the office and visitors' apartments a wooden pier extended into the river. The whole was raised on piles above high-water mark. There was a rude mill for grinding sugarcane, worked by bullocks; but cashaça, or rum, wus the only article manufactured from the juice. Behind the buildings was a small piece of ground cleared from the forest, and planted with fruit-trees, orange, lemon, gen. ipapa, guyava, and others ; and beyond this, a broad path through a neglected plantation of coffee and cacro, led to several large sheds, where the farinha or mandion meal was manufactured. The plantations or miandioca are always scattered about in the forest, some of them being on islands in the middle of the river. Land being plentiful, and the plough, as well as, indeed, nearly all other ayricultural implements, unknown, the same ground is not planted three years together; but a new piece of forest is cleared every alternate year, and the old clearing suffered to relapse into jungle.

We stayed here two days, sleeping ashore in the apartment devoted to strangers. As usual in Brazilian houses of the middle class, we were not introduced to the female members of the family, and, indeed, saw nothing of thers except at a distance. In the forest and thickets about the place we were tolerably successful in collecting, finding a number of birds and insects which do not occur at Pará. I saw here, for the first time, the s.- blua Chatterer (Ampelis cotinga). It was on the topmost bough of a very lofty tree, and completely out of the reach of an ordinary fowling-piece. The leautiful lightblue color of its plumage was plainly discernible at that distance. It is a dull, quiet bird. A much commoner species was the Cigana or Gypsy (Opisthocomus cristutus), a bird belon ving to the same order (Gallinacea) as our domestic fowl. It is abo'nt the size of a pheasant ; the plumage is dark brown, varied with reddish, and the head is adorued with a crest of long feathers. It is a remarkable bird in many respects. The hind toe is not placed high above the level of the other toes, as it is in the fowl order generally, but lies on the same plane with them; the shape of the foot becomes thus suited to the purely arboreal habits of the bird, enabling it. to grasp firmly the branches of trees. This is a distinguishing character of all the birds in equinoctial America which represent the fowl and pheasant tribes of the old world, and affords another proof of the adartation of the Fauna to a forest regrion. The Cigana lives in considerable flocks on the lower trees and bushes bordering the streams and lagoons, and feeds on various wild fruits, especially the sour Goyava(Psidium sp.). The natives say it devours the fruit of arborescent Arums (Caladium ariorescens), which grow in crowded masses around the swampy banks of lagoons. Its voice is a harsh, grating hiss; it makes the noise when alarmed, all the individuals sibilating as they fly heavily away from tree to tree, when disturbed by passing canoes. It is polygamous, like other members of the same order. It is never. however, by any chance, seen on the ground, and is nowhere domesticated. The flesh has an unpleasant odor of musk combined with wet hides-a smell called by the Brazilians cstinga ; it is, therefore, uneatuble. If it be as onpalatable to carn:vorous animals as it is to man, the immunity from persecution which it would thereby enjoy would account for its existing in such great numbers throughout the country.

We lnst here another of our crew ; and thus, ai the commencement of our voyage. 
had besu-e $u$ prospect of being forced to return, from sueer'waut of hands to manage the canoe. Senhor Gomez, to whom we had brought letters of introduction from Senhor Jouס̄ Augusto Correia, a Brazilian gentleman of high standing at Pará, tried what he could do to induce the canoe-men of his neighborhood to engage with us, but it was a vain endeavor. The people of these parts seemed to be above working for wages. They are nuturally indolent, and besides, have all sume little business or plantation of their own, which gives them a livelihood with indepen. dence. It is difficult to obtain hands under any circumstances, but it was particularly so in our case, from being foreigners, and suspected, as was nutural among ignorant people, of being strunge in our habits. At length our host lent us two of his slaves to help us on unother stage, namely, to the village of Baiao,, where we had great hopes of having this, cur urgent want, supplied by the military commandant of the district.

September 2d.-The distance from Vista Alegre to Baiao is about twenty-five miles. We had but little wind, and our men were therefore obliged to row the greater part of the way. The oars used in such canves as ours are made by tying a stout paddle to the end of a long pole by means of woody rianas. The men take their stand on a raised deck, formed by a few rough planks placed over the arched covering in the fore part of the vessel, and pull with their backs to the stern. We started ut six A.M., and abcut sunset reached a point where the west channel of the river, along which we had been travelling since we left Cametá, joined a broader middle one, and formed with it a great expanse of water. The islands here seem to form two pretty regular lines, dividing the great river into three channels. As we progressed slowly, we took the montaria and went ashore, from time to time, to the houses, which were numerous on the river banks as well as on the larger islands. In low situations they had a very unfinished appear. ance, being mere frameworks raised high on wooden piles, and thatched with the leaves of the Ubussú palm. In their construction another palm-tree is made much use of, viz., the Assai (Euterpe olearcea). The outer purt of the stem of this species is hard und tough as horn ; it is split into nurrow planks, and these form a great portion of the walls and flooring. The residents told us that the western channel becomes nearly dry in the mid. dle of the fine season, but that at high water, in April and May, the river rises to the level of the house-floors. The river bottom is everywhere sandy, and the country perfectly lealthy. The people seemed to be all con. tented and happy, but idleness and poverty were exhibited by nany unmistakable signs. As to the flooding of their island abodes, they did not seem to care about that at all. They seem to be ulmrst amphibious, or as much at home on the water as on land. It was really alarming to see men and women and children, in little leaky cances laden ty. tha waicr-lerel with bag and bag wooge, crossing bruad reaches of river. Most of them. have houses also on the terra firmu, and reside in the cool palm-swamps of the Ygapo islands, as they are called, only in the hot and. dry season. They live chiefly on fish, shellfish (among which were large Ampullariæ, whose flesh I found, on trial, to be a very tough morsel), the never-failing farinha, and the fruits of the forest. Among the latter the fruits of the palm-tree occupied the chief place. The Assai is the most in use, but this. forms a universal article of diet in all parts of the country. The fruit, which is perfectly rouud, and about the size of a cherry, contains but a small portion of pulp lying between the skin and the hard kernel. This is: made, with the addition of water, into $a$. thick, violet-colored beverage, which stains the lips like blackberries. The fruit of the Mirití is also a common article of food, al. though the pulp is sour and unpalatable, at least to European tastes. It is boiled, and then eaten with farinha. The Tucumá (Astrocaryum tucuma), and the Mucujá (Acro. comia lasiospatha), grow unly on the main. land. Their fruils yield a yellowish, fibrous: pulp, which the natives eat in the same way as the Mirití. They cuntain so much fatty matter that vultures and dogs devour them. greedily.

Early on the morning of September $3 d$ we: reached the right or eastern bank, which is here from forty to sixty feet high. The houses wers more substantially built thun those we had hitherto seen. We succeeded in buying a small turtle ; most of the inliabitants had a few of these animals, which they kept in litile inclosures mude with stakes. The people were of the same class every7here, mamelucos. They were very civil ; we were not able,however, to purchase much fresh food from them. I think this was. owing to their really not having more than was absulutely required to satısfy their own needs. In these districts, where the people depend for animal food solely on fishing, there is a period of the year when they suffer hunger, so that they are disposed to prize highly a small stock when they have it. They generally unswered in the negative when we asked, money in hand, whether they had fowls, turtles, or eggs to sell, “Naס, ha, siuto que naó pusso lhe ser bom ;" or, "Nao ha, meu coracao." "We have none ; I am sorry I caunot oblige you ;" or, " There is none, my beart.'

September $3 d$ to 7 th.-At half past eight A.M. we arrived at Baia $\overline{\text {. which is built on } a}$ very high lauk, and contaius about 400 in. habitants. We had to climb to the village up a sadder, which is fixed agaiust the bauk, aud on arriving at the top, took possession of a room which Senhor Seixas had given orders. to be prepared for us. He himself was away at his sitio, and wnuld not be here till tho next day. Wu were now quite dependent on him for men to cuable us to conliuue our voyage, and so liat n') remely but to wait. his leisure. The situilion of the place, and 
nature of the woods around it, promised well for novelties in birds and insects ; so we had no reason to be vexed at the delay, but brought our apparatus and store-boxes up from the canoe, and set to work.

The easy, lounging life of the people :amused us very much. I afterward had plenty of time to hecome used to tropical village life. There is a free, familiar, pro bono publico style of living in these small places, which requires some time for a European to fall intu. No sooner were we established in our rooms than a number of lazy young fellows came to look on and make remarks, and we had to answer all sorts of questions. The houses have their doors and windows open to the street, and people walk in and rout as they please ; there is always, however, an more secluded apartment, where the female imembers of the families reside. In their familiarity there is nothing intentionally offensive, and it is practiced simply in the desire to be civil and sociable. A young mameluco, named Soares, an Escrivuō, or ipublic ckerk, took me into his hcuse to show me his library. I was rather surprised to see a number of well-thumbed Latin classics, Virgil, Terence, Cicero's Epistles, and Livy. I was nut familiar enough, at this early period of my residence in the country, with Portuguese to converse freely with Senhor Suares, or ascertain what use he mude of these 'books; it was an unexvected sight, a classical library in a mud-plastered and palm. thatched hut on the banks of the Tocantius.

The prospect from the village was magnificent, over the green wooded islands, far away to the gruyline of forest on the opposite shore of the Tocantins. We were now well out of the low alluviul country of the Amazons proper, and the climate was evidently much arier than it is near Parḱ. They had had no rain here for many weeks, and the atmosphere was hazy around the horizon; so much so that the sun, before setting, glared like a Blooci-red globe. At Pará this never hapDens ; the stars and sun are as clear and sharply defined when they peep above the udistant tree-tops as they are at the zenith. This beautiful transparency of the air arises, doubtless, from the equal distribution through it of invisible vapor. I shall ever remember, in one of my voyages along the Pará river. the giand spectacle that was once presented .at sunrise. Our vessel was a large schooner, :and we were bounding along before a spanking breeze, which tossed the waters into foam, 'when the day dawned. Sn clear was the ;air that the lower rim of the full moon reanained sharrly defined until it touched the western horizon, whilc, at the sume time, the sun rose in the east. The two great orbs were visible at the same time, and the pas. :sage from the moonlit night to day was so gentle that it secmed to be only the brightening of dull weather. The woods around \#aiao were of second growth, the ground having been formerly cultivated. A great number of coffee and cotton-trees grew mong the thickets. A fine woodland path- way extends for miles over the high, undulating bank, leading from one house to another along the edge of the cliff. I went into se, eral of them, and talked to their inmates. They were all poor people. The men were out fishing, some far away, a distance of many days' journey ; the women plant mundioca, make the farinha, spin and weave cotton, manufacture soap of burnt cucao-shells and andiroba oil, and follow various other domestic employments. I asked why they allowed their plantations to run to waste. They said that it was useless trying to plant anything hereabout ; the Saüba ant devoured the young coffee-trees, and every one who attempted to contend against this universal ravager was sure to be defeated. The country, for many miles along the bunks of the river, seemed to be well peopled. The inhabitants were nearly all of the tawny-white mameluco class. I saw a good many mulattoes, but rery few negroes and Indians, and none that could be called pure whites.

When Senhor Seixas arrived, he acted very kindly. He provided us at once with two men, killed an ox in our honor, and treated us altogether with great consideration. We were not, however, introduced to his family. I caught a glimpse once of his wife, a pretty little mameluco woman, as she was tripping with a young girl, whom I supposed to be her daughter, across the back yard. Both wore long dressing-gowns, made of brightcolcred calico print, and had long wooden tobacco-pipes in their mouths. The room in which we slept and worked had formerly served as a storeroom for cacao, and at night I was kept uwake for hours by rats and cockroaches, which swarm in all such places. The latter were running about all over the walis ; now and then one would come suddenly with $u$ whirr full at my face, and get under my shirt if I attempted to jerk it off. As to the rats, they were chasing one anuther by dozens all night long, over the floor, up and down the edges of the doors, and along the rafters of the open roof.

September $7 t h$. - We started from Baiaō at an early hour. One of our new men was a good-humored, willing young mulatto, named José ; the other was a sulky Indian, called Manoel, who seemed to have been pressed into our service against his will. Senhor Seixas, on parting, sent a quantity of fresh provisions on board. A few miles above Baiao the channel hecame very shallow ; we got aground several times, and the men had to disembark and shove the vessel off. Alexandro here shot several fine fish, with bow and arrow. It was the first time I had scen fish captured in this wav. The arrow is a reed, with a steel-barbed point, wbich is fixed in a hole at the end, and secured by fine twine made from the fibres of pineapple leaves. It is only in the clearest water that fish cun be thus shot; and the only skill required is to make, in taking aim, the proper allowance for refraction.

'The next day before sunrise a fine breeze sprang up, and the men awoke and set the 
sails. We glided all day through channels between islands with long white sandy beaches, over which, now and then, aquatic and wading birds were seen running. The forest was low, and had a harsl, dry uspect. Several palm-trees grew here which we had not before seen. On low bushes, near the water, pretty red-headed tanagers ('Tanagra gularis) were numerous, flitting about and chirping like sparrows. About half past four P.M. we brought to at the mouth of a creek or channel, where these was a great extent of sandy beach. The sand had been blown by the wind into ridges and uudulations, and over the moister paits large flocks of sandpipers were running about. Alexandro and I had a long ramble over the rolling plain, which came as an agrecable change after the monotonous forest scenery amid which we had been so long travelling. He pointed out to me the tracks of a huge jaguar on the sand. We found here, also, our first turtle's nest, and obtained 120 eggs from it, which were laid at a depth of neally two feet from the surface, the mother first excavating a hole, and afterward covering it up with sand. The place is discoverable only by following the tracks of the turtle from the water. I saw here an alligator for the first time, which reared its head and shoulders above the water just after I had taken in bath near the spot. The night was calm and cloudless, and we employed the hours before bedtime in angling by moonlight.

(On the 10 ti we 1 eached a small settlement called Patos, consistiug of ubout a dozen houses, and built on a high rocky bank, on the eastern shore. The rock is the sume nodular conglomerate which is found at so many places, from the sea-coast to a distance of 600 miles up the Amazons. Mr. Leavens made a last attempt here to engage men to accompany us to the Araguaya; but it was in vain : not a soul could be induced by any amount of wages to go on such an expedition. The reports as to the existence of cedar were very vague. All said that the tree was plentiful somewhere, but no one could fix on the precise locality. I believe that the cedar grows, like all other forest trees, in a scattered way, and not in masses anywhere. The fact of its being the principal trec observed floating down with the curient of the Amazons, is to be explained by its wood being much lighter than that of the majority of trees. When the banks are washed away by currents, trees of all specles fall into the river; but the heavier ones, which are the most numerous, sink, and the lighter, such as the cedar, alone float down to the sea.

Mr. Leavens was told that there were cedar trees at Trocará, ou the opposite side of the river, near some fine rounded hills covered with forest, visible from Patos; so there we went. We found here several families encamped in a delightful spot. The shore sloped gradually down to the water, and wis shaded by a few wide spreacling trees. There was no underwoud. A great number of hammocks were seen slung between the tree-trunks, and the litter of a numerous household lay scattered about. Women, old and young, some of the latter very goodl-looking, und a large number of children, beside pet animals, enliveued the encampment. They were all half-breeds. simple, well-disposed people, and explaine to us that they were inhabitants of Cametá, who had come thus far. eighty miles, to spend the summer months. The only motive they could give for coming was, "that it was so. hot in the tow in the verao (summer), an I they were all so fond of fresh fish." "Thus these simple folks think nothing of learinghome and business to come on a three months' picuic. It is the annual custom of this class of people, throughout the province, to spend a few months of the fine season in the wilder parts of the country. They carry with them all the farinha they can scrape together, this being the ouly article of food necessary to provide. The men hunt and fish. for the day's wants, and sometimes collect a little india-rubber, sarsaparilla, or copaiba oil, to sell to traders on their return; thet women assist in paddling the canoes, do the cookiny, and soinetimes fish with rod and line. The weather is enjoyable the whole time, and so days and weeks pass happily away.

One of the men volunteered to walk with us into the forest, and show us a few cedartrees. We passed thruugh a mile or two of spiny thickets, and at length came upon the banks of the rivulet Trocará, which flows. over a stony bed, and, about a mile above its. mouth, falls over a ledge of rocks. thus forming a very pretty cascade. In the neighborhood we found a number of specimens of a curious laud-she:1. a large flat Helix, with a labyrinthine mouth (Anastoma). We learned afterwurd that it was a species which had been discovered a few years previously by Dr. Gardner, the botanist, on the upper part of the Tocantins.

We saw here, for the first time, the splended hyacinthine macaw (Macrocercus hyacinthinus, Lath., the Araruna of the natives), one of the finest and rarest species of the Parrot family. It only occurs in the interior of Brazil, from $16^{\circ} \mathrm{S}$. lat. to the southeru border of the Amazons valley. It is threefeet long from the beak to the tip of the tail. and is entirely of a soft hyacinthine blue color, except round the eyes, where the skin. is naked and white. It flies in pairs, ant feeds on the hard nuts of several palms, but. especially of the Mucuja (Acrocomia lasiospatha). These nuts, which are so hurd as to be ditticult to break with a heavy hammer. are crushed to a pulp by the powerful beak of this macaw.

Beiny unable to obtain men, Mr. Leavens: now gave up his project of ascending the river as fur as the Araguaya. He assentect to our request, however, to ascend to the calaracts near Arroyos. We started therefore: from Patos with a more definite aim before: us than we had hitherto had. The river be- 
came $m$ re picturesque as we advanced. The waler was very low, it being now the helurlit of the dry seuson; the islands were ssinaller than those further down, and some of them were high and rocky. Bold wooded b) shores were fringed with beaches of glistening white sand. On one side of the river there was an extensive yrassy plain or campo with isolated patches of trees scaltered over it. On the 14th and following day we stopped several times to ramble ashore. Our longest excursion was to a large shallow lagoun, choked up with aquatic plants, which lay absut two miles across the campo. At a place called Juquerapuá we engaged a pilot to conduct us to Arroyos, and a few miles ab we the pilot's house, arrived at a point where it was not possible to advance further in our large canoe, on account of the rapids.

September 16 th. -Embarked at six A.M. in a large montaria which had been lent to us for this part of the voyage by Senhor Seixas, leaving the vigilinga anchored close to a rocky islet, named Santa Anna, to await our retuin. A ten A.M. We arrived at the first rapicls, which aı called Tapaiunaquára. "The river, which was here about a mile wide, was choked up with rucks, a broken ridge passing completely acruss it. Between these confused piles of stone the currents were feaıfully strong, and formed numeruus ed. dies and whirlpools. We were obliged to get out occasionally and walk from rock to rock, while the men dragged the canoe over the obstacles. Beyond Tapaiunaquára the stream became again broad and deep, and the river scenery $w$ as beautiful in the extreme. The water was clear, and of a bluish-green color. On botll sides of the stream stretched ranges of wooded hills, and in the middle picturesque islets rested on the smooth water, whose brilljant green woods fringed with palms formed churming bits of foreground to the perspective of sombre hills fading into gray in the diszance. Joaquim pointed out to us grove after grove of Brazil-nut-trees (Bertholletia excelsa) on the mainland. This is one of the chief collecting grounds for this nut. The tree is one of the loftiest in the forest, towering far above its fellows; we could see the wisily fruits, large and round as cannon. bulls, dotted over the branches. Tine currents were very strong in some places, so that lluring the greater part of the way the men prif "red to travel near the shore, and propel the hoit by means of long poles.

IV e: arived at Arroyos about four o'cluck i) 1h: afternoon, after ten hours' hard pull. "Tis: place consists simply of a few houses luilt on a high bank, and forms a station wher cianoe-men from the mining countries of lic interior of Brazil stop to rest themselves, hefore or after surmounting the drea led falls and rapids of Guaribas, situated a couple of miles further up. We diued ashore, and in the evening again embarked to visit the falls. The vigorous and successful way in which our men battled with the terrific currents excited our astonishment.
The bed of the river, here about a mue wide, is strewn with blocks of various sizes, which lie in the most irregular manner, and between them rush currents of more or less rapidity. With an accurate knowledge of the place and skilful management, the fulls can be approached in small canoes by threading the less dangerous channels. Tine main fall is about a quarter of a mile wide; we climbed to an elevation overlooking it, and had a good view of the cataract. A borly of ! water rushes with terrific force down a steep slope, and boils up with deafening roar around the boulders which obstruct its course. The wildness of the whole scene was very impressive. As far as the eye could resch stretched range after range of wooded hills, scores of miles of beautiful wilderness, inhabited only by scanty tribes of -wild Indians. In the midst of such a solitude the roar of the cataract seemed fitting music.

September 17th. - We commenced early in the morning our downward voyage. Arroyos is situated in about $4^{\circ} 10^{\prime} \mathrm{S}$. lat., and lies, therefore, about 130 miles from the mouth of the Tocantins. Fifteen miles above Guaribas another similar catalact, called Tubocas, lies across the river. We were told that there were in all fifteen of these obstrurtions to navigation between Arroyos and the mouth of the Araguaya. The worst was the Inferno, the Guaribas standing second to it in evil reputation. Many cannes and lives have been lost here, most of the accidents arising through the vessels be.ng hurled against an enormous cubical mass of rock called the Guaribinha, which we, on our trip to the falls in the small canoe, passed round with the greatest ease about a quarter of a mile below the main falls. This, however, was the dry season; in the time of full waters a tremendous current sets aguinst it. We descended the river rapidly, and found it excellent fun shooting the rapids. The men seemed to delight in choosing the swiftest parts of the current; they saug und yelled in the greatest excitement, working the paddles with great force, and throwing clouds of spray above us as we bounded downward. We stopped to rest at the mouth of a rivulet named Caganxa. The pilot told us that gold had been found in the bed of this brook; so we had the curiosity to wade several hundred yards through the icy cold waters in search of it. Mr. Leavens seemed very much interested in the matter ; he picked up all the shining stones lie could espy in the pebbly bottom, in hopes c $f$ finding diamonds also. There is, in fact, no reasun why both guld and diamonds should not be found here, the hills being a continuation of those of the mining countries of interior Brazil, and the brooks flowing through the narrow valleys between them.

On arriving at the place where we had left our canoe, we stayed all night and part of the following day, and I had a stroll along a delightful pathway, which led over hill and dale, two or three miles through the forest. I was surprised at the number variety of 
Trillian $11 y$-colored butterflies ; they were all of small size, and started forth at every step 1 took, from the low.bushes which boldered the roid. I first heard here the notes of a trogon: it was seated alone on a branch, at no great elevation; a beautiful bird, with glossy-yreen back and rose-colored breast (probably Trogon melanurus). At intervals it uttered, in a complaining tone, a sound resembling the words "qua, quá." It is a dull inactive bird, and not very ready to take light when approached. In this respect, nowever, the trogons are not equal to the jacamars, whose stupidity in remaining at their posts, seated on low branches in the y!oomiest shades of the forest, is somewhat remarkable in a country where all other birds are exceedingly wary. One species of jacauar was not uncommon here (Galbula viridis); I sometimes saw two or three together, seated on a slender branch, silent and motionless with the exception of a slight movement of the head; when an insect flew past within a short distance, one of the birds would dart off, seize it, and return again to jts sitting-place. The trigons are found in the trupics of both hemispheres; the jacamars, which are clothed in plumage of the most beautiful golden-bronze and steel col. ors, are peculiar to tropical America.

At night I slept ashore as a cliange from the confinement of the canne, having obtained permission from Senhor Juaquim to sling my hammock under his roof. The house, like all others in these out-of-the-way parts of the country, was a large, open, palm-thatched sled. having one end inclosed by means of partitions, also made of palm. leaves, so as to form a private apartment. Under the shed were pluced all the household utensils ; earthenware jars, pots, and kettles, hunting and fishing implements, paddles, bows and arrows, harpoons, and so f rih. One or two common wooden chests serve to contain the holiday clothing of the females; there is no other furniture, except u few stools and the hammock, which un. swers the purposes of chair and sofa. When a visitor enters, he is asked to sit down in a liammock: persons who are on intimate terms with each other recline together in the same hammock, one at each end; this is a very convenient arrangement for friendly conversation. There are neither tables nor chaits; the cloth for meals is spread on a Imat, and the guests squat round in any position they choose. There is no cordiality of manners, but the treatment of the guests shows a keen sense of the duties of hospitality on the part of the host. There is a gond deal of formality in the intercourse of these half-wild mamelucos, which, I believe. hus been chiefly derived from their Indian forefathers, although a little of it may have been copied from the Portuguese.

A little distance from the house were the open sheds under which the farinha for the use of the establishment was manufactured. In the centre of each shed stood the shallow vans, made of clay and built over ovens where the meal is roasted. A long flexible cyiiuder made of the peel of a marantaceous plant, plaited into the proper form, hung sus. pended from a beam; it is in this that the pulp of the mandioca is pressed, and from it the juice, which is of a highly poisonous nature, although the pulp is wholesome food, runs into pans placed beneath to receive it. A wooden trough. such as is used in all these places for receiving the pulp before the poisonous matter is extracted, stood on the ground, and from the posts hung the long wicker-work baskets, or aturas, in which the women carry the roots from the roça or charing; a broad ribbon made from the inner bark of the monguba-tree is attached to the rims of the laskets, and is passed round the forehead of the carriers, to relieve their backs in supporting the heavy load. Around the shed were planted a number of banana and other fruit trees; among them were the never - failing capsicum-pepper bushes, brilliant us holly-trees at Christmas time, with their fiery-red fruit, and lemontrees; the one supplying the pungent, the other the acid, for sauce tc the perpetual meal of fish. There is never in such places any appearance of careful cultivation, no gaiden or orchard; the useful trees are surrounded by weeds and bushes, and close behind rises the everlasting forest.

In descending the river we landed fre. quently, and Mr. Wallace and I lost no chance of adding to our collections; so that before the end of our juurney we had got together a very considerable number of birds, insects, and shells, chiefly taken, however, in the low country. Leaving Baiao, we touk our last farewell of the limpid waters and varied scenery of the upper river, and found ourselves again in the humid flat region of the Amazons valley. We suiled duwn this lower part of the river by a different channel from the one we travelled along in ascending, and frequently went ashore on the low islands in mid-river. As already stated, these are cov. ered with water in the wet season; but at this tinse, there having been three munths of fine weather, they weite dry throughout and, by the subsidence of the waters, placed tour or five feet above the level of the river. They are covered with a inost luxuriant forest, comprising a large number of india-rubber trees. We found several people encamped here, who were engaged in collecting and preparing the rubber, and thus had an opportunity of observing the process.

The tree which yields this valuable sap is the siphonia elastica, a member of the Euphorbiaceous order; it belongs, therefore, to a group of plants quite different from that which furuishes the caoutchouc of the East Indies and Africa. This latter is the product of different species of Ficus, and is consid. ered, 1 believe, in commerce $u n$ inferior article to the india-rubber of Pará. The siphonia elastica grows only on the lowlands in the Amazons region; hitherto the rubber has been cullected chiefly in the islands and swaupy parts of the mainland within a dis- 
tance of fi cy to a hundred miles to the west of Pará; wut there are plenty of untapped trees still growing in the wilds of the Tapajos, Madeira, Jucuá, and Jauraí, as far as 1800 miles from the Atlantic coast. The tree is not remarkable in appearance ; in bark and foliage it is not unlike the European ash ; but the trunk, like that of all forest trces, shoots up to an immense height before throw. ing off branches. The trees seem to be no man's property hereabout. The people we met with told us they came every year to collect rubber on these islands, as suon as the waters had subsided, namely, in August, and remained till January or Fehruary. The process is very simple. Every morning each persun, man or woman, to whom is allotted a certain number of trees, goes the round of the whole, abd collects in a large vessel the milky sap which trickles from gushes made in the bark on the preceding evening and which is received in little clay cups, or in ampullaria shells stuck beneath the wounds. The sap, which at first is of the cousistence of cream, sonn thickens; the collectors are provided with a great number of wouden moulds of the shape in which the rubber is wanted. and when they return to the camp they dip them into the liquill laying on, in the course of several days, one cnat after another. When this is done, the substance is white and hard ; the proper color and consistency are given by passing it repeatedly through a thick black smoke obtained by burning the nuts of certain palm-trees, after which process the article is ready for sale. India-rubber is known thruughout the province only by the name of seringa, the Portuguese word for syringe; it owes this appellation to the circumstance that it was in this form only that the first Portuguese settlers noticed it to be employed by the aborigines. It is said that the Indians were first taught to make syringes of rubber by seeing natural tubes formed by it, when the spontaneously-fluwing sap gathered round projecting twigs. Brazilians of all classes still use it extensively in the form of syringes, for injections form a great feature in the popular system of cures ; the rubber for this purpose is made into a pear-shaped bottle, and a quill fixed in the long neck.

Septemuer 24th.-Opposite Cametá the islands are all planted with cacao, the tree which yields the chocolate nut. The forest is not cleared for the purpose, liut the cacao plants are stuck in here and there almost it random among the trees. There are many houses on the banks of the river, all elevated abore the swampy soil on wooden piles, and furnished with broad ladders by which to mount to the ground floor. As we passed by in our canoe we could see the people at their occupations in the open verandas, and in one place saw a ball going on in broad daylight; there were fiddles and guitars hurd ut work, and a number of lads in white shirts and trousers dancing with brown damsels clad in showy print dresses. The cacan-tree produces a curious impression, on account of the flowers and fruit growing directly out ot the trunk and branches. There is a whole group of wild-fruit trees which have the same habit in this country. In the wildernesses where the cacau is planted, the collecting of the fruit is dangerous from the number of noisonous snakes which inhabit the places. One day, when we were running our montaria to a landing-place, wc saw a large serpent on the trees overhead, as we were ahout to brush past ; the boat was stopped just in the nick of time, and Mr. Leavens brought. the reptile dowa with a charge of shot.

September 26th. - At length we got clear of the isiands, and saw once more before us the sea-like expanse of waters which forms the mouth of the Tocantins. The tiver had now sunk to its lowest point, and numioers of fresh. water doiphins were rolling about in shoa!y places. There are here two species, one of which was new to science when I sent specimens to England. It is called the 'Tucuxí (Stenn tucuxi of Gray). When it comes to the surface to breathe, it rises horizuntally, showing first its back fin; draws an inspiration, and tuen dives gently down, head foremost. This mode of proceeding distinguishes the Tucuxí at once from the other species, which is called Bouto or porpnise by the natives (Inia Geoffroyi of Desmarest). When this rises, the top of the head is the part first. seen ; it then blows, and immediately afterward dips head downward, its back curving over, expusing successively the whole dorsal ridge with its fin. It seems thus to pitch heels over head, but does not show the tail fin. Besides this peculiar motion, it is distinguished from the Tucuxí by its habit of gen. erally going in pairs. Both species are exceedingly numerous throughout the Amazuns, and its larger tributaries, but they are nowhere more plentiful than in the shualy water at the mouth of the Tocantins, especially in the dry season. In the Cpper Amazons a third pale flesh colored species is alsoahundant (the Delphinus pallidus cf Gervais). With the exception of a species found in the: Ganges, all other varieties of dolphin inhahit exclusively the sea. In the broader parts of the Amazons, fron its mouth to a uistance of fifteen hundred miles in the interior, one. or other of the three kinds here mentioned are always heard rolling, blowing, and snurting, especially at night, and these noises contribute much to the impression of sea-wide vastness and desolation which haunts the: traveller. Besides dolphins in the water, frigate-birds in the air are characteristic of this lower part of the Tocantins. Flocks of them were seen the last two or three days of our journey, hovering about at an immense height. Toward night we were obliged to cast anchor over a shoal in the middle of the river to await the ebb tide. The wind blew very strongly, and this, together with the incoming flow, caused such a heavy sea that it was impnssible to sleep. The vessel rolled and pitched until every bone in our bodıes. ached with the bumps we receivetl, and we were all more or less sta-sick. On the fol- 
Jowing day we entered the Anapú, and on the 30th of September, after threading again the labyrinth of channels communicating between the Tocantins and the Mojú, arrived at Pará.

I will now give a short account of Cameta, the principal town on the banks of the Tocan. tins, which I visited for the second time in June, 1849 ; Mr. Wallace, in the same month, departing from Pará to explore the rivers Guamá and Capim. I embarked as passenyer in a Cameta trading-vessel, the St. John, z small schooner of thirty tons burden. aad learned by this time that the only way to attain the oljects for which I had come to this country was to accustom myself to the ways of life of the humbler classes of the in. habitants. A traveller on the Amazons gains little by being furnished with letters of recommendation to persons of note, for in the great interior wildernesses of forest and river the canoe-men have pretty nuch their own way; the authorities cannot force them to grant passages or to hire themselves to travellers, and therefore a stranger is obliged to ingratiate himself with them in order to get conveyed from place to place. I thoroughly enjoyed the journey to Cameta; the weather was again beantiful in the extreme. We started from Pará at sunrise on the 8th of June, and on the 10th emerged from the narrow claunels of the Anapú into the broad Tocautins. The vessel was so full of cargo, that there was no room to sleep in the cabin ; so we passed the nights on deck. The captain, or supercargo, called in Portuguese cabo, was a mameluco, named Manoel, a quiet, good-humored person, who treated me with the most unaffected civility during the three days' journey. The pilot was also a mameluco, named John Mendez, a handsome young fellow, full of life and spirit. He had on board a wire guitur or viola, as it is here culled; and in the bright mounlight nights, as we lay at anchor hour after hour waiting for the tide, he enlivened us all with songs and music. He was on the best of terms with the cabo, both sleeping in the same hammock slung between the masts. I passed the nights wrapped in an old sail outside the roof of the cabin. The crew, five in number, were Indians and half-breeds, all of whom treated their two superiors with the most amusing familiarity, yet I never sailed in a better managed vessel than the St. John.

In crossing to Cametá we had to await the flood-tide in a channel called Entre-as-Ilhas, which lies between two islands in mid-river, and John Mendez, being in good tune, gave us an extempore song. cousisting of a great number of verses. The canoe-men of the Amarons have many songs and choruses, with which they are in the habit of relieving the mouotony of their slow voyages, and which are known all over the interior. The choruses consist of a simple strain, repeated almost to weariness, and sung generally in unison, but sometimes with au uttempl at harmony. There is a wildness and sadness about the tunes which harmonize well with, and in fact are born of, the circumstances of the canne-man's life : the echoing channels, the endless gloony forests, the solemn nights, and the desolate seenes of broad and stormy waters and falling banks. Whether they were invented by the Indians or introduced by the Portuguese it is hard to decide, as many of the customs of the lower classes of Portuguese ure so similar to those of the Indians that they have become blend. ed with them. One of the commonest songs is very will and pretty. It has for refrain the words "Mai, Mai," ("Mother, mother"), with a long drawl on the second word. The stanzas are very variable. The best wit on board starts the verse, improvising as he goes on, and the others join in the chorus. They all relate to the loneiy river life and the events of the voyage ; the shoals, the wind; how far they shall go before they stop to sleep, and so forth. The sonorous nutive names of places, Goajará, Tucumandúba, etc., add gieatly to the charm of the wild music. Sometimes they bring in the stars thus :

$$
\begin{aligned}
& \text { Malua está sahindo, Mai! } \\
& \text { M lua está sahindo, } \\
& \text { Mai, Mai! } \\
& \text { As sete estrellas estao chorando, } \\
& \text { Mai, Mai! } \\
& \text { Por s'acharem desamparados, } \\
& \text { Mai, Mai! } \\
& \text { The moon is rising, } \\
& \text { Mother, Mother ! } \\
& \text { The moon is rising, } \\
& \text { Mother, Mother ! } \\
& \text { The seven stars (Ple ades) are weeplng, } \\
& \text { Mother, Mother! } \\
& \text { To find themselves forsaken, } \\
& \text { Mothur, Muther ! }
\end{aligned}
$$

I fell asleep about ten o'clock, but at four in the morning John Mendez woke me to enjoy the sight of the little schconer tearing through the waves before a spanking breeze. The night was transparently clear and almost cold, the moon appeared sharply defined against the dark blue sky, and a ridge of foam marked where the prow of the vessel was cleaving "its way through the water. The men had made a fire in the galley, to make tea of an acid herb called erva cidreira a quantity of which they had gathered at the last landing-place, and the flames sparkled cheerily upward. It is at such times as these that Amazon travelling is eujoyable, and one no longer wonders at the love which many, both natives and strangers, have for this wandering life. The little schooner sped rapidly on with booms bent and sails stretched to the utmost. Just as day dawned, we ran with scarcely slackened speed into the port of Cametá, and cast anchor.

I stayed at Cameta until the 16th of July, and made a considerable collection of the natural productions of the neighborhood. The town in 1849 was estimuted to contain about 5000 inhabitants, but the municipal district of which Cametá is the capital numbers 20,000 : this, however, comprised the whole 
of the lower part of the Tocantins, which is the most thickly populated part of the province of Para. The productions of the district are cacao, india-rubber, and Brazil uuts. The most remarkable feature in the social aspect of the piace is the hybrid uature of the whole population, the amalgamation of the white and Indian races being here complete. The aborigines were originally very numerous on the western bank of the Tucantins, the principal tribe having been the Camútas, from which the city takes its name. They were a superior nation, settled, and attached to agriculture, and received with open arms the white immigrants who were attracted to the district by its fertility, natural beauty, and the liealth ful. ness of the climate. The Portuguese settlers were nearly all males, the Indian women were good-looking and made excellent wives; so the natural result has been, in the course of two centuries, a complete blending of the two races There is now, however, a considerable infusion of negro blood in the mixture, several hundred African slaves having been introduced during the last seventy years. The few whites are chiefly Portu. guese, but there are also two or three Brazil. ian families of pure European descent. The town consists of three long streets, running parallel to the river, with a few shorter ones crossing them at right angles. Tine houses are very plain, being built, as usual in this country, simply of a strong framework, filled up with mud, and couted with white plaster. A few of them are of two or three stories. There are three churches, and ulso a small theatre, where a company of native actors, at the time of my visit, were representing light Portuguese plays with considerable taste and ability. The people have a repucation all over the province for energy and perseverance; and it is often said that they are as keen in trade as the Purtuguese. The lower classes are as indolent and sensual here as in other parts of the province, a moral condition not to be wondered at in a country where perpetual summer reigns and where the neeessaries of life are so easily obtained. But they are light-hearted, quick-witted, communicative, and hospitable. I found here a native poet, who had written sume pretty verses, sbowing an appreciation of the natural beauties of the country, and wus told that the Archbishop of Bahia, the Primute of Brazil, was a native of Cametá. It is interesting to find the mumelucos displaying talent and euterprise, for it shuws that degeneracy does net necessarily result from the mixture of white and Indian blood. The Cametaenses boast, as they have a right to do, of theirs being the only large town which resisted successfully the anarchists in the great rebellion of 1835-6. While the whites of Pará were submitting to the rule of half-savage revolutionists, the mamelucos of Cametá placerl themselves under the leadership of a courageous priest, numed Prudencio, armed themselves, fortified the place, and repulset the large forces which the insurgeistef of Dará sent to attack the place. The town not only became the refuge for all loyal subjects, but was a centre wheuce large parties of volunteers sallied forth repeatedly to attuck the anarchists in their various strongholds.

T'he forest behind Cametá is traversed by several broad ruads, which lead over undulating grouud many miles into the interiur. They pass generally under shade, and part of the way through groves of coffee and orange trees, fragrant plantations of cacac, and tracts of secoud-growth wuods. The narrow brouk-watered valleys, with which the land is intersected, alone have remained clothed with primeval forest, at least neur the town. 'The houses along these beautiful. roads belong chiefly to mameluco, mulatto, and Indian families, each of which has its: own small plantation. There are only a few planters with larger establishments, and theso have seldom more than a dozen slaves. Besides the main roads, there are endless bypaths which thread the forest and communicate with isolated houses. Along these the traveller may wander day after day without leaving the shade, and every where meet with cheerful, simple, and hospitable people.

Soon after lauding I was introduced to the most distinguished citizen of the place, Dr. Angelo Custodio Correia, whom I have already mentioned. This excellent man was a favorable soecimen of the highest class of native Brazilians. He had been educated in Europe, was now a member of the Brazilian Parliament, and had been twice president of his native provinee. His manners were less formal, and his goodness more thoroughly genuine, perhaps, than is the rule geneially with Brazilians. He was admiredand loved. as I had ample opportunity of observing, throughout all Amazonia. He sacrificed his. life in 1855 , for the good of his fellow townsmen, when Cametá was devastated by the: cholera; having stayed behind with a few heroic spirits to succor invalids and direct the burying of the dead, when nearly all the chief citizens had fled fiom the pluce After he had done what he could he emharkid for Pará, but was himself then attacked with cholera, and died on board the stesmer before he reached the capital. Dr. Angelo received me with the usual kindness which he showch to all strangers. He procured me, unsolicited, a cliuming country house, free of rent, hired a muatio servant for me, and thus relieved nie of the many annoyances and ciclays attendant on a first arrival in a country town where even the name of an inu is unknown. The rocinha thus given up for my residence belonged to a friend of his, Senhor José Raimundo Furtado, a stout florid-complexioned gintleman, such a one as might be net with any day in a country town in England. To him also I was.indebted for many acts of kinduess.

The rocinha was situated near a broad, grassy road botdered by lotty woods, which leads from Cametá to the Aldcia. a village two miles distant. My first walks we re aiong this road. From it branches anotler similar 
but stın nure picturesque road, which runs to Curimá and Pacajá, two small settlements, several miles distant, in the heart of the forest. The Curima road is beautiful in the extreme. About half a mile from the house where I lived it crosses a brook flowing through a deep dell, by means of a long rustic wooden bridge. The virgin forest is here left untouched; numerous groups of slender palms, mingled with lofty trees overrun with creepers and parasites, fill the shady glen and arch over the bridge, forming one of the most picturesque scenes imaginable. A little beyond the bridge there was an extensive grove of orange and other trees, which yield. ed me a rich harvest. The Aldeia road runs parallel to the river, the land from the border of the road to the indented shore of the Tocantins forming a long slope, which was also richly wooded; this slope was threaded by numerous shady paths, and abounded in beautiful insects and birds. At the opposite or southern end of the town there was a broad road called the Estrada da Vacaria; this ran along the banks of the Tocantins at some distance from the river, and continued over hill and dale, through bamboo thickets and palm swamps, for ahout fifteen miles.

At Cametá I chanced to verify a fact relauing to the habits of a large hairy spider of the genus Mygale, in a manncr worth recording. The species was M. avicularia, or one very closely allied to it ; the individual was nearly two inches in lengtl of body, but the legs expanded seven inches, and the entise body and legs were covered with coarse gray und reddish hairs. I was attraeted by a movement of the monster on a tree-trunk ; it was close beneatl a deep crevice in the trec, across which was stretched a dense white web. The lower part of the web was broken, and two small birds, finches, were entangled in the pieces ; they were about the size of the English siskin, and I judged the two to be male and fenialt. One of them was quite dead; the other lay under the body of the spider not quite dead, and was smeared with the fithy liquor or saliva exuded by the monster. I drove away the spider and took the birds, but the second one soon died. The fact of species of Mygale sallying forth at night, mounting trees, and sucking the eggs and young of humming-birds, has been reeorded Iong ago by Madame Merian and Palisot de Beaurois; but, in the absence of any confirmation, it has come to be discredited. From the way the fuct has been related it would appear that it had been merely derived from the report of natives, and had not been witnessed by the narrators. Count Langsdorff, in his" "Expedition into the Interior of Brazil," states that he totally disbelieved the story. I found the circumstance to be quite a novelty to the residents hereabout. The Myga!es are quite common insects; some species make their cells under stones, others form artistic tunnels in the earth, and some build their dens in the thatch of houses. The natives call them Arunhas carangueijeiras, or crab-spiders. The hairs with which they are clothed come off when touched, and cause a peculiar and almost maddening irritatiou. The first specimen that I killed and prepared was handled incautiously, and I suffered ter. ribly for three days afterward. I think this is not owing to any poisonous quality residing in the hairs, but to their being short and hard, and thus getting into the fine creases of the skin. Some Mygales are of immense size. One day I saw the children belonging to an Indian family, who collected for me, with one of these monsters secured by a cord round its waist, by which they were leading it about the house as they wonld a doy.

The only monkeys I observed at Cametá were the Couxio (Pitheciu Satanas)-a large species, clothed with long brownish-black hair - and the tiny Midas argentatus. The Couxio has a thick bushy tail, and the hair of the head, which looks as if it had been carefully combed, sits on it like a wig. It inbabits only the most retired parts of the forest, on the terra firma, and I olsserved nothing of its habits. The little Midas argentatus is one of the rarest of the American monkeys; indeed, I bave not heard of its being found anywhere except near Cametá, where I once saw three individuals, looking: like so many white kittens, running along a branch in a cacao grove; in their motiuns they reserabled precisely the Midas ursulus already described. I saw afterward a pet. animal of this species, and hearl that thore were many so kept, and that they were esteemed as grcat treasures. The une mentioned was full grown, although it meásured only seven inclies in length of body. It wus covered with long white silky hairs, the tail being blackish, and the face nearly naked and flesh-colored. It was a most timid and sensitive little thing. The woman who owned it carried it constantly in her bosom, and no money would induce her to part with her pet. She called it Mico. It fed frum her mouth, and allowed her to fondle it freely, but the nervous litule creature would not per mit strangers to touch it. If any one at. temp!cd to do so, it shrank back, the whule body trembling with fear, and its teeth chattered while it uttered its tremulous frightened tones. The expression of its featuics was like that of its more robust brother, Midas ursulus; the eyes which were black, wero full of curiosity and mistrust, and were always kevt fixed on the person who attempted to auvans:e toward it.

In the orange groves and other parts humming-birds were plentiful, but I did not no. tice more than three species. I saw one day a little pygmy belonging to the genus Phaethornis in the act of washing itself in a brook. perched on a thin branch, one end of which was uuder water. It dipped itself, then fluttered its wings and preened its fenthrers, and seemed thoroughly to enjoy itself, alone in the sliarly nock $w$ hich it had chosen-n place overshatowed by broad leares of ferns and Helicunix. I thought, as I watched it, that there was no neel for poets to invent elves and gnumes, while nature furuishes us 
with such marvellous little sprites ready to haud.

My return-journey. to Pará afforded many incidents characteristic of Amazonian travel. ling. I left Cametá on the 16th of July. My luggage was embarked in the morning in the Santa Rosa, a vessel of the kind called cuberta, or covered canoe. The cuberta is very much used on these rivers. It is not decked, but the sides forward arc raised, and arched over, so as to admit of cargo being piled high above the water-line. At the stern is a neat square cabin, also raised, and b) tween the cabin and covered forepart is a nurrow piece decked over, on which are placed the cooking arrangements. This is called the tombadilha or quarterdeck, and when the canoe is heavily laden it goes und r $r$ water as the vessel heels over to the wind. There are two masts, rigged with fore and aft sails. The foremast has often, besides, a main and top sail. The forepart is planked over at the top, and on this raised deck the crew work the vessel, pulling it along, when there is no wind, by means of the long oars already described.

As I have just said, my luggage was em. barked in the morning. I was informed that we siniculd start with the ebb-tide in the afternoon, so I thought I should have time to lay my respects to Dr. Angelo and other friends, whuse extreme courtesy and goodness bad made my residence at Cametá so agreeable. After dinner the guests, according to custom at the house of the Correias, walked into the cool veranda which overluoks the river; and there we saw the Santa Rosa, a mere speck in the offing miles away, tacking down river with a fine breeze. I was $\mathrm{n} J \mathrm{w}$ in a fix, for it would be useless attempting to overtake the cuberta, and besides the sea ran too high for any montaria. I was then tuld, that I ought to have been ibuard hours befure the time fixed for starting, because when a breeze springs up, wessels siart before the tide turns, the last hour of the fluod not being very strong. All my precious collections, my clothes, and other necessaries were on board, aud it was indispensable that I should be at Pará when the things were disembarked. I tried to hire a montaria and men, but was told that it would be madness to cross the river in a small boat with this breeze. On yoing to Senhor Larocjue, anutber of ny Cameta friends, I was reliever oi $\mathrm{my}$ embirrassment ; for I found there an English gentleman. Mr. Patchett, of Peruanbues, who was visiting Pará and its neighborhood on his way to England, and who, as he was going back to Pará in a small boat with four paddles, which would starl at inidnight, kindly offered me a passage. The evening from seven to teu $0^{\prime}$ clock was very stormy. About seven, the night bicame intensely dark, and a terrific squall of wind buist forth, which made the loose tiles tly over the house-tops; to this succeed. ed lightning and stupendors claps of thurder bcth neariy simultaneous. We had hai se" eral of these short and sharp sturms during the past month. At midnight, when we em. barked, all was as calm as though a ruffle had never disturhed uir, forest, or river. The boat sped along like an arrow to the rhythmic paddling of the four stout youths we had with us, who eulivened the pasasge with their wild songs. Mr. Patchett and I tried to get a little sleep, but the cabin wus so small and encumbered with boxes placed at all sorts of angles, that we found sleep impossible. I was just dozing when the day dawned, and, on awaking, the first object I saw was the Sunta Rosa, at anchor beside a green island in mid-river. I preferred to make the remainder of the voyage in com pany of my collections, so bade Mrr. Patchett good-day. The owner of the Santa Rosa, Senhor Jacinto Machado, whom I bad not seen before, received me aboard, and apolo. gized for having started without me. He was a white man, a planter, and was now taking his year's produce of cacao, about twenty tons, to Pará. The canoe was very heavily laden, and I was rather alarmed to see that it was leaking at all points. The crew were all in the water, diving about to feel for tie holes, which they stopped with pieces of rag and clay, and an old negro was baling the water out of the hold. This was a pleisant prospect for a three-days' voyage. Senhor Machado treated it as the most ordinary incident possible: "It was always likely to leak, for it was an old vessel that had been left as worthless high and dry on the beach, and he had bought it very cheap." Wher the leaks were stopped, we proceeded on our journey, and at night reached the mouth of the Anapú. I wrapped myself in an old sail, and fell asleep on the raised deck. The next dav v.e threaded the Igarapé-mirim and on the 19th descended the Mojí. Senhor Machado and I by this time had become very good frienfls. At every interesting spot on the banks of the Mojú, he manned the small boat and took me ashore. There are many large houses on this river, belonging to what were formerly large and flourishing plantations, but which, since the Revolution of 1835-6, had been suffered to go to decay. Two of the largest buildings were constructed by the Jesuits in the early part of the last century. We were told that there were formerly eleven large sugar-mills on the banks of the Mojú, while now there are only three. At Burujúba there is a large monastery in a state of ruin ; part of the edifice, however, was still inhabited by \& Brazilian family. The walls are four feet in thickness. The long dark corridors and gloomy cloisters stiuck me as very inappropriate in the midst of this young and radiunt nature. They would be better in place on some barren moor in Nolthern Europe, than here in the m:dst of perpetual summer. The next turn in the river below Burujúba brouglit the city of Pará into view. The win i was now against us, and we were ohliged w. $\|^{1}, u t$. Toward evening it began to wow situt!. the vessel hetled over vers 
much, and Senhor Machado, for the first time, trembled for the safety of his cargo; the leaks burst out afresh, wheu we were yet two miles from the shore. He ordered another sail to be hoisted, in order to run more quickly into port, but soon afterward an ex. tra puff of wind cume, and the old boat lurched alarmingly, the rigging gave way, and down fell boom and sail with a crash, encumbering us with the wreck. We were then obliged to have recourse to oars; and as soon us we were near the land, fearing that the crazy vessel would sink before reaching port, I begged Seuhor Machado to send me ashore in the boat, with the more precious portion of my collections.

\section{CHAPTER V.}

CARIPI AND THE BAT OF MARAs 6.

River Pará and Bay of Maraj6-Jonrney to CaripiNegro Observance of Christmas-A German Family - Bats-Ant-eaters-Humming-birds-Excursion to the Murucupí-Domestic Life of the InhabitantsHunting Excursion with Indians-White Ants.

That part of the Pará River which lies in front of the city, as I have already explained, forms a narrow channel, being separated from the main waters of the estuary by a cluster of islands. This channel is about two miles broad and constitutes part of the minor estuary of Goajará, into which the three riv. ers Guamá, Mojú, and Acará discharge their waters. The main channel of the Para lies ten miles away from the city, directly across the river ; at that point, after getting clear of the islands, a great expanse of water is be. held, ten to twelve miles in widtl ; the opposite shore-the island of Marajó-being visıble only in clear weather as a line of treetops dotting the horizon. A little further upward, that is, to the south-west, the main. land on the right or eastern shure appears ; this is called Carnapijo ; it is rocky, covered with the never-ending forest, and the coast, which is fringed with broad saudy beaches, describes a geutle curve inward. The broad reach of the Pará in frout of this cuast is called the Ballia, or Bay of Marajó. The coast and the interior of the land are penpled by civilized Indians and manelueos, with a mixture of free negroes and mulat toes. They are poor, for the waters ale not abundant in fish, and they are dependent for a liveilihood solely on their small plantations, and the scanty supply of game found in the woods. The district was originally peopled by various tribes of Indians, of whom the principal were the Tupinambis and Nhengalíbas. Like all the coast tribes, whether inhabiting the banks of the Amazons or the sea-shore between Pará and Bahia, they were far more advanced in civilization than the hordes scattered through theinterior of the country, some of which still remain in the wild state, between the Amazons and the Plata. There are three villages on the coust of Carnapijó, and several planters' houses, formerly the centres of flourishing estates, which have now relapsed into forest in consequence of the scarcity of labor and diminished enter- prise. One of the largest of these establishment is called Caripí. At the time of which I am speaking it belonged to a Scotch gentleman, Mr. Campbell, who had married the daughter of a large Brazilian proprietor. Most of the occasional English and American visitors to Pará had made sone stay at Caripí, and it had obtained quite a reputa. tion for the number and beanty of the birds and insects found there. I therefore applied for and obtained permission to spend two or three months at the place. The distance from Pará was about 23 miles, round by the northern end of the Ilha das Onças (Isle of Tigers), which faces the city. I bargained for a passage thither with the cabo of a small trading-vessel, which was going past the place, and started on the rth of December, 1848.

We were 13 persons aboard : the cabo, his pretty mulatto mistress, the pilot, and five Indian canoemen, three young mamelucos (tailor's apprentices who were taking a holiday trip to Cametá), a runaway slave heavily chained, and myself. The young mamelucos were pleasant, gentle fellows; they could read and write, and ainused themselves on the voyage with a book containing descriptions and statistics of foreign countries, in which they seemed to take great interestone reading while the others listened. At Uirapiranga, a small island behind the Ilha das Ouças, we had to stop a sbort time to embark several pipes of cashaça at a sugar estate. 'The cabo took the montaria and two men; the pipes were rolled into the water and floated to the canoe, the men passing calles round and towing them through a rough sea. Here we slept, and the following morning, continuing our voyage, entered a narrow channel wilich intersects the land of Carnapijó. At two P.M. we emergel from this channel, which is called the Aitituba, or Arrozal, into the lroad Bahia, and then saw, two or three miles away tu the left, the red-tiled mansion of Caripi, embosomed in woods on the shores of a cliarming little bay.

I remained here nine weeks, or until the 12th of February, 1849. The house was very large and most sulstantially built, but consisted of nnly one story. I was told it was built by the Jesuits more than a century ago. The front had $n$ i) veranda, the doors opening on a slightly-elevated terrace, about a hundred vasds distant from the broad sandy beach. Around the residence the ground had been cleared to the extent of two or three acres, and was planted with fruit-trees. Well-trodien pathways through the furest led to little colonies of the natives, on the banks of retired ereeks anil rivulets in tho interior. I led hete a solitary but not unpleasant life; for there was a great churm ia the loneliness of the place. The swell of the river beating on the sloping beach causerl an unceasing nurmur, which lulle 1 ne to sleep at night, and seemed appropriate music in those mid-day hours when all nature was pausing breathless under the rays of the ver- 
tical sun. Here I spent my first Christmas day in a foreign land. The festival was celebrated by the negroes of their own free will, and in a very pleasing manner. The room next to the onc 1 had chosen was the capella, or chapel. It had a little altar which was neatly arranged, and the room was furnished with a magnificent brass chandelier. Men, women, and children were busy in the chapel all day on the 24th of December, decoratiug the altar with flowers and strewing the floor with orange-leaves. They invited some of their neighbors to the evening prayers; and when the simple ceremuny began, an hour before midnight, the chapel was crowded. They were obliged to dispeuse with the mass, for they had no priest ; the service, therefore, consisted merely of a long litany and a few lyymns. There was placed on the altar a small image of the infant Christ, the "Menino Deos," as they called it, or the child god, which had a long ribbon depending from its wrist. An old white-haired negro led off the litany, and the rest of the people joined in the responses. After the service was over they all went up to the altar, one by one, and kissed the end of the ribbon. The gravity and earnestness shown throughout the proceedings were remarkable. Sorne of the hymns were very simple and beautiful, especially one beginning " Virgem soberana," a trace of whose melody springs to my recol lection whenever I think on the dreamy solitude of Caripí.

The first few nights I was much troubled by bats. The room where I slept had not been used for many mouths, and the roof was open to the tiles and rafters. The first night I slept soundly and did not perceive anything unusual, but on the next I was aroused about midnight by the rushing noise made by vast hosts of hats sweeping about the room. The air was alive with them; they had put out the lamp, and when I relighted it the place appeared blackened with the impish multitudes that were whirling round and round. After I had laid about well with a stick for a few minutes they disappeared among the tiles, but when all was stili again they returned, and once more extinguished the light. I took no further notice of them, and went to sleep. The next night several got into my hammuck; I seized them as they were crawling orer me, and dashed them against the wall. The next morning I found a wound, evidently caused by a bat, on my hip. This was rather unpleasant, so I set to work with the negroes and $t$ ied to exterminate them. I shot a great many as they hung from the rafiers, and the negroes, having mounted with ladders to the roof outside, routed out from beneath the eaves many hundreds of them, including young broods. There were altcgether four species - two belonging to the genus Dysopes, one to Phyllostoma, and the fourth to Glossophaga. By far the greater number belunged to the Dysopes perotis, a species having very large ears, and measuring two feet from tip to tip of the wings. The Phyllostoma was a small kind, of a dark-gray color, streaked with white down the back, and having a leaf-shaped fleshy expansion on the tip of the nose. I was never attucked by bats except on this occasion. The fact of their sucking the blood of persons sleeping, from wounds which they make in the toes, is now well established; but it is only a few persons who are subject to this blood-letting. According to the negroes, the Phyllostoma is the only kind which atiacks man. Those which I caught crawling over me were Dysopes, and I am inclined to think many differ. ent kinds of bats have this propensity.

One day I was uccupied scarching for insects in the bark of a fallen tree, when I saw a large cat-like animal advancing toward the spot. It came within a dozen yards before perceiving me. I had no weapon with me but an old chisel, and was getting ready to defend myself if it should make a spring, when it turned round hastily and trotted off. I did not ubtain a very distinct view of it, but I conld see its color wns that of the Puma, or American Lion, although it was rather too small for that species. The Puma is not a common auimal in the Amazon forests. I did not see altogether more than a dozen skins in the possession of the natives. The fur is of a fawn color. On account of its hue resembling that of a deer (:nmmon in the forests, the natives call it the Sassú. arina,* or the false deer ; that is, an animal which deceives one at first sight by its superficial resemblance to a deer. The hunters are not at all af raid of it, and speak always in disparaging terms of its courage. Of the Jaguar they give a very different account.

The only species of monkey I met with at Caripi was the same dark-colored little Midas already mentioned as found near Pará. The great Ant-eater, Tamanduá of the natives (Myrmecophaga jubata), was not uncommon here. After the first few weeks of residence I ran short of fresh provisions. The people of the neighborhood had sold me all the fowls they could spare, I had not yet learned to eat the stale and stringy salt-fish which is the staple frod in these places, and for several days I bad lived on rice-porridge, roasted bananas, and farinha. The housekeeper asked me whether I could eat Tamanduá. I told her almost anything in the shape of flesh would be acceptable; so the same day she went with an old negro named Antonio and the dogs, and in the evening bronght one of the animals. The meat was stewed, and turned out very good, something like goose in flavor. The people at Caripí would not touch a morsel, saying it was not considered fit to eat in these parts ; I had read, however, that it was an article of food in other coun tries of South America. During the next two or three weeks, whenever we were short of fresh meat, Antonio was always ready, for

* The old zoologist Marcgrave called the Pnma the Cuguacnarina, probably (the c's being soft) a mis. spelling of Sassú-arána; hence the name Cougour. employed by French zoologists, and cupied in most works on uatural history. 
: a small reward, to get me a Tamanduá. But oue day he came to me in yreat distress, with the news that his favorite $\mathrm{dog}$, Atrevido, had been caught in the grip of an ant-cater, and was killed. We hastencel to the place, and found the dog was not diead, but severely torn by the clitws of the animal, which itself was mortaliy wounded, and was nuw relaxing its grasp.

The harits of the Myrmecophaga jubata are now pretty well kuown. It is not uncummon in the drier forests of the Amazons villey, but is not found, I believe, in the Yyapó, or flooded lands. The Bruzilians (all the species the Tamanduá bandeira, or the Banuer Ant-eater, the term banner being applied in allusion to the curious coloration of the auimal, each side of the body having a houd ollique stripe, half gray and half black, which gives it some resemblance to a heraldic banner. It has an excessively lung slender muzzle, and a wormlike extensile fongue. Its jaws are destitute of teeth. The claws are much elongated, aud its gait is very awkward. It lives on the ground, and feeds on termites, or white ants, the loug claws being employed to pull in pieces the solid hillocks made by the insects, and the long flexible tongue to lick them up from the crevices All the other species of this singular genus are arboreal. I met with four species altogether. One was the Myrmecophaga tetradactyla; the two others, more curious and less known, were very small kinds, called Tamanduá-i. Both are similar in size-ten inches iv length, exclusive of the tail -and in the number of the claws, having two of unequal length to the anterior feet, and four to the hind feet. One species is clotbed with grayish-yellow silky hair ; this is of rare vccurrence. The other has a fur of a dingy brown color, without silky lustre. One was brought to me alive at Caripi, hav. jng been caught by an Indian, clinging motionless insicle a hollow tree. I kept it in the house about twenty-four hours. It had a unoderately long snout, curved downward, and extrumely small eyes. It remained nearly all the time without motion, except when irritated, in which case it reared itself on its hind legs from the back of a chair to which it clung, and clawed out with its forepaw like a cat. Its manner of clinging with i:s claws, and the sluggishness of its motions, r. 1 ve it a great resemblance to a sloth. It uttered no sound. and remaiued all night on the sprot where I had placed it in the mornjug. The next day I put it on a tree in the open air, aud at nirht it escaped. These si:all Tamanduís are nocturnal in their liabits, and feed on those species of termites which construct earthy nests, that look like ugly excrescences, on the trunks and branches of irees. The different kinds of ant-euters ure tluus adapted to various modes of life, terrestrial aud arboreal. Those which live on trees are again either diurnal or nocturnal, for Myrmecophaga tetradactyla are seen moring along the main branches in the daytim". The allied group of the Sloths, which are still more exclusively South Americun forms than ant-eaters are, at the present timt, furnish arboreal species only, but formerly terrestrial forms of sloths also existed, as the Megatherium, whose mode of life was a puzzle, seeing that it was of too colossal a size to live on trees, until Owen showed how it might have obtained its food from the ground.

In January the orange trees became cov ered with blossom-at least to a greater extent than usual, for they flower more or liss in the country all the year round-and the fluwers attracted a great number of humming-birds. Every day in the cooler hours of the morning, and in the evening from four o'clock till six, they were to be seen whirling about the trees by scores. Their motions are unlıke those of all other birds. They dart to and fro so swiftly that the eye can scarcely fullow them, and when they stop before a flower it is only for a few moments. They poise themselves in an unsteady manner, their wings moving with in. conceivable rapidity. probe the flower, and then shout off to another part of the tree. They do not proceed in that methodical manner which bees follow, raking the flowers seriatim, but skip about from one part of the tree to another in the most capricious way. Sometimes two males close with each other and fight, mounting upward in the struggle, as insects do when similarly engaged, and then separating hastily and dart ing back to their work. Now and then the] stop to rest, perching on leafless twigs, where they may be sometimes secu probing, from the places where they sit, the flowers within their reach. The brilliant colors with which they are adorned cannot be seen while they are fuuttering alout, nor can the different species be distinguished unless they have a deal of white hue in their plumage, such as Heliothrix auritus, which is wholly white underneath, although of a glittering green culor above, and the white-tailed Florisuga mellivora. There is not a great variety of humming-birds in the Amazons region. the number of species being far smaller in these uniform forest plains than in the diversitied valleys of the Andes, under the same parallels of latitude. The family is divisible into two groups, cuntrasted in form and habits, one containing species which live entirely in the shade of the forest, and the other comprising those which prefer open sunny places. The forest species (Phaethorninæ) are seldom seen at flowers, flowers being, in the shady places where they abide, of rare occurrence; but they search for insects on leaves, threading the bushes and passing above and beneath each leaf with wonderful rapidity. The other group (Trochilinæ) are not quite con. fined to cleared vlaces, as they come into the forest wherever a tree is in blussom, and de. scend into sunny openings whete flowars are to be found. But it is only where the wouds are less drinse than usual that this is the ("l-e ; in the lofty forests aud 1 wilight shades of the lowland and islands they are scarcely 
ever seen. I searched well at Caripi, expecting to find the Lophornis Gouldii, which I was told had been obtained in the locality. This is one of the most beautiful of all humming-birds, having round the neck a frill of long white feathers tipped with golden green. I was not, however, so fortunate as to meet with it. Several times I shot by mistake a humming-bird hawk-moth instead of a bird. This moth (Macroglossa Titan) is somewhat smaller than humming birds generally are, but its manner of flight, aud the way it poises itself before a flower while probing it with the proboscis, are precisely like the same actions of humming-birds. It was only after muny days' experience that I learued to distinguish one from the other when on the wing. This resemblance has attracted the notice of the natives, all of whom, even educated whites, firmly believe that one is transmutable into the other. They have observed the metamorphosis of caterpillars into butterflies, and think it not at all more won. derful that a moth should change into a humming-bird. The resemblance between this hawk-moth and a humming.bird is certainly very curious, and strikes one even when both are examined in the hand. Holding them sideways, the shape of the head and position of the eyes in the moth are seen to be nearly the same as in the bird, the extended pro. boscis representing the long beak. At the tip of the moth's hody there is a brush of long hair-scales resembling feathers, which being expanded, looks very much like a bird's tail. But, of course, all these points of resemblance are merely superficial. The neyroes and Indians tried to convince me that the two were of the same species. "Look at their feathers," they said, "their eyes are the same, and so are their tails." This belief is so deeply rooted that it was useless to reason witl them on the subject. The Macroglossa moths are found in most countries, and have everywhere the same habits; one well-known species is found in England. Mr. Gould relates that he once had a stormy altercation with an English gentleman, who affirmed that humming. birds were found in England, for he had seen one flying in Devonshire, meaning thereby. the moth Macroglussa stellatarum. The analogy between the two creatures has been brought about, probably, by the similarity of their habits, there being no indication of the one having been adapted in outward appearance with reference to the other.

It has been observed that humming-birds are unlike other birds in their mental qualilies, resembling in this respect insects rather than warm-blooded vertebrate animals. The want of expression in their eyes, the small degree of versatility in their actions, the quickness and precision of their movements, are all so many points of resemblance between them and inseets. In walking along the alleys of the forest a Phuethornis frequently crosses one's path, often stopping suddenly and remaining poised in mid-air, a few feet distant from the face of the intruder.
'The Phaethorninæ are certainly more numer: ous in individuals in the Amazon regione: than the Trochilinæ. They build theirnests, which are made of fine vegetable fibres: and lichens, densely woven together and. thickly lined with silk cotton from the fruit. of the samaüma-tree (Eriodendron samaüma). on the inner sides of the tips of palm-fronds. They are long and purse-shaped. The yuunir. when first hatched have very much shorter bills than their parents. The only spuciec. of Trochilinæ which I found at Caripí wete the little brassy-green Poly tmas viridissimus. the sapphire and emerald (Thalurania. furcata), and the large falcate-winged Cam. pylopterus obscurus.

Snakes were very numereus at Caripí; many harmless species were found near the house, and these sometimes came into the rooms. I was wandering one day among the green bushes of Guajará, a tree which yields a grape-like berry (Chrysobalanus Icaco) anil grows along all these sandy shores, when $I$. was startled by what appeared to be the flexu. ous stem of a creeping plant endowed with life and threading its way among the leaves and branches. This animated liana turned out to be a pale-green snake, the Dryophis: fulgida. Its whole body is of the same green hue, and it is thus rendered undistinguishable amid the foliage of the Guajará buslies, where it prowls in search of its prey, treefrogs and lizards. The forepart of its head: is prolonged into a slender pointed beak, and the total length of the reptile was six feet. There was another kind found among buslies on the borders of the forest, closely allied to. this, but much more slender, viz., the Dryothis acominata. This grows to a length of 4 feet 8 inches, the tail alone being 22 inclies : but the diameter of the thickest pait of the body is little more than a quarter of an inch. It is of light-brown color, with iridescent: shades, variegated with obscurer markings, and looks like a piece, of whip-cord. One individual which I caught of this species had a protuberance near the middle of the borly. On opening it I found a half-digested liztrd: which was much more bulky than the snake itself. Another kind of serpent found here, a species of Helicops, was amphibious in its : hubits. I saw several of thls in wet wealler ${ }^{-}$ on the beach, which, on being approsclied, always made straightway for the wilter, where they swam with much grace and dex. terity. Florinda, the huusekeeper, on. day caught a Helicops while angling for $f i=h$, it having swallowed the fish-hook with the bait. She and others told me these water-suakcs. lived on small fishes, but I did nut meet will any proof of the siatement. In the words, snakes were constantly occurring; it was not often, however, that I saw poisnnous species. There were muny arhoreal kinds, besides the $t$ wo just mentioned; and it was rather alarming, in eutomologizing alout the truuks of tices, to suddenly encunnter, on turuing round, as scmetimes happened, a pair of glittering eyes and a forked ting'ie - wallin a few inclies of one's liead. The last. 
kind I shall mention is the Coral snake, which is a most beautiful object when seen coiled up on black soil in the woods. The one I saw here was banded with black and vermilion, the black bands having each two clear white rings. The state of suecimens preserved in spirits can give no idea of the brilliant colors which adorn the Coral snake in life.

In company with Petzell, a German settler near Caripi, I made many excursions of long extent in the neighboring forest. We sometimes went to Murucupí, a creek which nasses through the forest about four miles behind Caripí, the banks of which are inhabited by Indiaus and half-breeds, who have lived there for many generations in perfect seclusion from the rest of the world, the place being little known or frequented. A path from Caripi leads to it through a gloumy tract of virgin forest, where the trees are so closely packed together that the ground beneath is thrown into the deepest shade, under which nothing but fetid fungi und rotting vegetable débrrs is to be seen. On einerging from this unfriendly solitude near the banks - of the Murucupí, a charming contrust is pre. sented. A glorious vegetation, piled up to an immense height, clothes the banks of the creek. which traverses a broad tract of semi. cultivated ground, and the varied masses of greenery are lighted up with a sunny glow. Open palm-thatched huts peep forth here and there from amid groves of banana, mango, cotton, and papaw trees and pilms. On our first excursion, we struck the bauks of the river in frout of a house of somewhat more substantial architecture than the rest. having finished mud walls, plastered and whitewashed, and a covering of red tiles. It seemed to be full of childreu, and the aspect of the household was improved by a number of good-looking mameluco women, who were busily employed washing, spinning, and making farinha. Two of them, seated on a mat in the open veranda, were euguged sew. ing dresses; for a festival was going to take place a few days hence at Balcurem, a village pight miles distant from Murucupí, and they intended to be present to hear mass and show their finery. One of the children, a naked boy about seven years of age, crosserl over with the montaria to fetch us. We were made welcome at once, and rsked to stay for linner. On our accepting the invitation a cnuple of fowls were killed, and a vibolesome stew of seasoned rice and fowls soon put in preparation. It is not often that the female members of a family in these retired places are familiar with strangers; but these people had lived a long time in the capital, and therefore were more civilized than their neighbors. Their father had been a prosperous tradesman and had given them the hest education the place afforded. After his death the widow with several daughters, married and unmarried, retired to this secluded spot, which had been their sitio, farm or country bouse, for many years. One of the daugh ters was married to a handsome young $\mathrm{m}:$ ? latto, who was presel. .ud sang us som? pretty songs, accumpanying himself on the guitar.

After dinner I expressed \& wish to seo more of the cresk, so a liveiy and polite old mau, whom I took to he one of the neighburs, volunteered as guide. We embarked in a little montaria, and paddied some three or four miles up and down the stream. Although I had now become familiarized with beautiful vegetation, all the glow of fresh adwiration came again to me in this place. The creek was ab.sut one hundred yards wide, but nar. rower in some places. Both banks were mask. ed by lofty walls of green drapery, here and there a break occurring, through which, under over-arching trees, glimpses were obtained of the palm-thatched huts of settlers. The projecting boughs of lofty trees, which in soms places stretched half-way acrais the creek, were hung with natural garlands and festoons, and an endless variety of creeping plants clothed the water-frontage, scme of which, especially the Bignonias, were crnamented with large gayly-colored flowers. Art could not have assorted together beautiful vegetable forms so harmoniously as was here done by nature. Palms, as usual, formed a large pro. portion of the lower trees; sume of them, however, shot up their slim sterss to a height of sixty feet or more, and waved their bunches of nodding plumes between us and the sky. One kınd of palm, the Pashiúba (Iriartea exorhiza), which grows here is greater abundance than elsewkere, was espe cially attractive. It is not one of the tallest kinds, for when full-grown its hoight is not more, perhaps, than forty fuet; the leaves are somewhat less drooping, and the leaflets much brouder than in other species, so that they have not that feathery appearance which souve of those palms have, but still they possess their own peculiar benuty. My guide put me ashore in one place to show me the ruots of the Pashiúba. These grow above ground, radiating froin the trunk many feet above the surface, so that the tree looks as if supported on stilts ; and a person can, in old trees, stand upright umong the roots with the perpendicular stem wholly above his head. It adrls to the singularity of their mnearance that these roots, which have the form of struight rods, are studded with stcut thorns, while the trunk of the tree is quite smooth. The purpose of this curious arrangement is: perhaps, similar to that of the bultitss roctis already described-nanely, to recompense the tree by root growth above the suil for its inability, in consequence of the competition of neighboring roots, to extend it usderground. The great amount of mcisture and nutriment contained in the atmosphere may aies, favor these growths.

On returning to the house, I fcund Petzell had been well uccupied during the lot hours of the duy collecting insects in a neighboring clearing. Uur kind hosts gave us a cup of coffee ubout five o'clock, and we then started for home. The last mile of our vails was 
performed in the dark. The forest in this part is obscure even in broad dayight, but I was scarcely prepared for the intense opacity of durkness which reigned here on this night, and which prevented us from seeing each other, although walking side by side. - Nothing occurred of a nature to alarus us, except that now and then a sudden rush was heard among the trees, and once a dismal shriek startled us. Petzell tripped at one place, and fell all his length into the thicket. With this exception, we kept well to thc pathway, ind in due time arrived safely at Caripí.

One of my neighbors ac Murucupi was a hunter of reputation in these parts. He was a civilized Iudian, married and settled, named Raimundo, whose habit was to sally forth at intervals to certain productive huntinggrounds, the situation of which he kept secret, and procure fresh provisions for his family. I had found out by this time that animal food was as much a necessary of life in this exhausting climate as it is in the North of Europe. An attempt which I made to live on vegetable food was quite a failure, and I could not eat the execruble salt fish which Brazilians use. I had been many days without meat of any kind, and nothing more was to be found near Caripí, so I asked as a fivor of Senhor Raimundo permission to accompany him on one of his hunting trips, and shoot a little game for my uwn use. He consented, and appointed a day on which I was to come over to his house to sleep, so as to be ready for starting with the ebb-tide shortly after midnight.

The locality we were to visit was situated near the extreme point of the land of Caruapijó, where it projects northwardly into the iniddle of the Pará estuary, and is broken into a number of islands. On the afternoon of January 11th, 1849, I walked through the woods to Raimundo's house, taking nothing with me but the double-barrelled gun, a supply of ammunition, and a box for the reception of any insects I might capture. Raimundo was a carpenter, and seemed to be a very industrious man; he had two apprentices, Indians like himself-one a young lad, and the other apparently about twenty years of age. His wife was of the same race. The Indian women are not always of a taciturn disposition like their husbands. Senhora Dominga was very talkative; there was another old squaw at the house on a visit, and the tongues of the two were going at a great rate the whole evening, using only the Tupí language. Raimundo and his apprentices were employed building a canoe. Notwithstanding his industry, he seemed to be very poor, and this was the condition of most of the residents on the banks of the Murucupí. They have, nevertheless, considerable plantations of mandioca and Indiun corn, besides small plots of cotton, coffee, and sugarcane; the soil is very fertile; they have no rent to pay, and no direct taxes. There is, moreover, always a market in Para, twen'v miles distant, for their surplus produce, as a ready conmunication with it by water.

In the evening we had more visilors. 'The sounds of pipe and tabor were heard, and presently a procession of villagers emerged from a pathway through the mandioca fields. They were on a begging expedition for St. Thomé, the patron saint of Indians and mamelucos. One carried a bauner, on whicl: was rudely painted the figure of St. Thic mé with a glory round his head. The pipe and tabor were of the simplest description. The pipe was a reed pierced with four holes, by means of which a few unmusical notes were produced, and the tabor was a broad hoop. with a skin stretched over each end. $\Lambda$ deformed young man played both the instruments. Senhor Raimundo received them with the quiet politeness which comes so natural to the Indian when occupying the position of host. The visitors, who had come from the Villa de Condé, five miles through the forest, were invited to rest. Raimundo then took the image of St. Thome from one of the party, and placed it by the side of Nussa Senhora in his own oratorio, a little decorated box in which every family kceps its household gods, finally lighting a couple of wax candles before it. Shortly afterward a cloth was laid on a mat, and all the guests were invited to supper. The fare was very scanty; a boiled fowl with rice, a slice of roasted pirarucu, farinha, and bananus. Each one partook very sparingly, some of the young men contenting themselves with a plateful of rice. One of the apprentices stood behind with a bowl of water and a towei with which each guest washed his fingers axil rinsed his mouth after the mea!. 'They stayed all night; the large cyen sned was filled with hammocks, which wereslung from pole to pole ; and on retiıing, Raimuudo gave orders for their breakfast in the morning.

Raimundo called me at two o'clock, when we embarked (he, his older apprentice, Joaquim, and myself) in a sluady place where it was so dark that I could see neither canoe nor water, taking with us five dogs. We glided cown a winding creek whtre huge irunks of trees slanted across close overhead, and presently emerged into the Murucupí. A few yards furtler on we entered the broader channel of the Aititúba. This we crossed, and entered another narrow creek on the opposite side. Here the ebb-tide was. against us, and we hud great difficulty in making progress. After we had struggled against the powerful current a distance of two miles, we came to a part where the ebbtide ran in the opposite direction, slowing that we had crossed the water-slied. The tide flows into this channel or cletk at both ends simultaneously, and meets in the middle, although there is apparently no difference of level, and the breadth of the water is the same. The tides are extremely intricate throughout all the infinite channels and creeks which intersect the lands of the Amazon delta. The moon now broke forth and lighted up the trunks of colossal trees, the leaves of monstrous Jupati julms which arched. 
o:er the creek, and revealed groups of arborescent arums standing like rows of spectres c.u its bauks. We had a glimpse now and then into the black deptlis of the forest, where all was silent except the shrill stridulation of wood crickets. Now and then a sudden plunge in the water aheud would startle us, caused by heavy fruit or some nocturnal animal dropring from the trces. The two Indians here rested on their paddles, and allowed the canoe to drift with the tide. A pleasaut perfume came from the forest, which Raimundo said proceeded from a cunefield. He told me that all this land was owned by large proprietors at Pará, who had received yrants from time to time from the Government for political services, Raimundo was quite in a talkative humor; he reJated to me many incidents of the time of the " Cabanagem," as the revolutionary days of 1835-6 are popularly called. He said he had been much suspected himself of being a rebel, but declared that the suspicion was unfounded. The only complaint he harl to make against the white man was, that he monopolized the land without having any intention or prospect of cuitivating it. He had been turned out of one place where he had squatted and cleared a large piece of forest. I be lieve the law of Brazil at this time was that the new lands should become the property of those who cleared and cultivated them, if their right was not disputed within a given term of years by some one who claimed the proprietorship. This land law has since been repealed, and a new one adopted, fourded on thut of the United States. Raimundo spoke of his race as the red-skins, "pelle vermelIo ;" they meant well to the whites, and ouly hegged to be let alone. "God," he said, " had given room enough for us all." It was pleasant to hear the shrewd, good-natured fellow talk in this strain. Our companion, Jorquim, had fallen asleep; the night air was cool, and the moonlight lit up the features of Raimundo, revealing a more animated expression than is usually observable in Indian countenances. I ulways noticed that Indians were more cheerful on a voyage, especially in the cool hours of night and morning, than when ashore. There is something in their constitution of body which makes them feel excessively depressed in the hot hours of the day, especiully inside their houses. Their skin is always hot to the touch. They certaiuly do not endure the beat of their own climate so well as this whites. The negroes are totally different in this respect; the heat of mid-day has very jittle effect on them, and they dislike the cold nights on the river.

We arrived at our hunting ground about half-past four. The channel was here broader, and presented several ramifications. It yet wanted an hour and a half to daybreak, so Raimundo recommended me to have, nap. We both stretched ourselves on the benches of the canoe und fell asleep, letting the b 12 drift with the tide, which was now slack I slf pt well, considering the hardness of our bed, and when I awoke, in ine middle of a dream about home scenes, the day was beginuing to dawn. My clothes were quito wet with the dew. The birds were astir, the cicadas had begutn their music, and the Urania Leilus, is strange and beautiful tailed and gilited moth, whose habits are those of a butterfly, commenced to fly in flocks over the tree-tops. Raimunilo exclaimed, "Clarciu o dia !"-" The day brightens !" 'The cisange was rapid ; the sky in the east assumed sud. denly the loveliest azure color, ucross which streaks of thin white clouds were painted. It is at such moments as this when one feels how beautiful our earth truly is ! The channel on whuse waters our little bout was float. ing was absut two hundred yards wide; others brancled off right and left, surround. ing the group of lonely islands which terminate the land of Caruapijó. The forest on all sides formed a lofty hedge without a break ; below, it was fringed with inangrove bushes, whose snall foliage contrasted with the large glossy leaves of the taller trees, or the feather and fan-shaped fronds of palms.

Being now arrived at our destination, Raimundo turned up his trousers and shirtsleeves, took his long hunting-knife, and leaped ashore with the dogs. He had to cut a gap in order to enter the forest. We expected to find Pucas and Cutías ; and the method arlopted to secure them was this: At the preseut early hour they would be seen feeding on fallen fruits, but would quickly, on hearing a noise, betake themselves to their burrows: Raimundo was then to turn them out by means of the dogs and Joaquim and I were to remain in the boat with vur gans, ready to shoot all that came to the edge of the stream-the habits of both animals, when hard-pressed, being to take to the water. We had not long to wait. The first arrival was a Paca, a reddish, nearly tailless Rodent, spotted with white on the sides, aud interme. diate in size and uppearance between a hog and a hare. My first shot did not take effect; the animal dived into the water aud did not reappear. A second was bruught down by my coinpanion as it was rambling about under the mangrove bushes. A Cutia next appeared; this is ulso a Rodent, about onethird the size of the Paca : it swims, but does not dive, and I was fortunate enough to shoot it. We obtained in this way two more Pacas and another Cutía. All the time the dogs were yclping in the forest. Shortly after. ward Raimundo made his appearauce, and told us to paddle to the other side of the island. Arrived there, we landed and prepared for breakfast. It was a pretty spot-a clean, white, sandy beach beneath the shade of wide-spreading trees. Joaquim made a fire. He first scraped tine shavings from the midrib of a Bacaba palm-leaf ; these he piled into a little heap in a dry place, and then struck a light in his bamboo tinder-box with a piece of an old fle and a flint, the tinder being a felt-like, soft substauce munufactured by an ant (Polyrhachis bispinosus). By gentle blowing the shavings ignited, cisy sticks 
were piled on them, and a good fire soon resulted. He then singed and prepared the cutia, finishing by running a spit through the body, and fixing one end in the ground in a slanting position over the fire. We had brought with us a bag of farinha and a cup containing a lemon, a dozen or two of fiery red peppers, and a few spoonfuls of salt. We breakfasted heartily when our cutía was roasted, and washed the meal down with a calabash full of the pure water of the river.

After breakfast the dogs found another cutía, which was hidden in its burrow two or three feet benenth the roots of a large tree, and took Raimundo nearly an hour to disinter it. Soon afterward we left this place, crossed the channel, and, paddling past two ieis \& Jbtained $\varepsilon$ glimpse of the broad rives rete them. rith a long sandy spit, on Fie if boed severul scared ibises and snow. rebit $t$ grets. One of the islands was low and cac dy, and half of it was covered with gigantic arum-trees, the often-mentioned Caladium arborescens, which presented a strange sight. Most people are acquainted with the little British species, Arum macula. tum, which grows in hedge-bottoms, and many, doubtless, have admired the larget kinds yrown in hot-houses ; they can there. fore form some idea of a forest of arums. On this islet the woody stems of the plants near the bottom were eight to ten inches in diameter, and the trees were twelve to fifteen feet high, all growing together in such a manner that there was just room for a man 60 walk freely between them. There was a canoe in-shore, with a man and a woman; the man, who was houting with all his might, told us in passing that his son was lost in the " aningal" (arum-grove). He had strayed while walking ashore, and the father tad been an hour waiting for him in vain.

Abuut one o'clock we again stopped at the mouth of a little creek. It was now intensely hot. Raimundo sald deer were found here; so he borrowed my gun, as being a more effective weapon than the wretched arms called Lazarinos, which ne, in common with all the native hunters, used, and which seli at Pará for seven or eight shillings apiece. Raimundu and Joaquim now stripped themselves quite naked, and started off in different directions through the forest, going naked in order to move with less noise over the carpet of dead ieaves, among which they stepped so stealthily that not the slightest rei3t) bo heard. The dogs remained E $4, \gamma=5$, the neighborhood of which I emp agerti isself two hours entomologizing. At the of that time my two companions Ieturned, having met with no game whatever.

We now embarked on our return voyage. Raimundo cut two slender poles, one for a mast and the other for a sprit : to these he rigged a sail we had brought in the boat, fos we ware to return by the open river, and expected a good wind to carry us to Caripí. As soon as we got out of the channel we began. to feel the wind-the sea-breeze, which hers makes a ciean sweep from the Atlant:. Curt boat was very small aisd heavily laxen; and when, after rounding a point, I saw the great brealth we had to taverse (seven miles), I thought the uttempt tc eross in such a slight vessel foolhardy in the extreme. The waves ran very high: there was no rudde $r$; iviimundo steered with a raddle, and all we siad to rely upon to save $x \cdot 3$ from falling into the trough of the sea and $b$, xing instantly s.vamped: were his nerve and ikill. There vas just room in the boat for cur three se ves, the dogs, und the game w. had killed; $\Omega$ id when between the swelling ridges of we' is in so. frail a shell, our desiruction seemad inevita. ble ; as it was, we shipped a little water now and then. Joaquimisssisted with ?. to steady the boat; n.y time was i.liy occupied in baling out tine water and watching the dogs, which were crowded together in. the prow, yelling with fear, one or other of them occasionally failing over the side and: causing great commotion in scrambing in. again. Off the poist was a ridge ef rocks, over which the surg; raged furiousiy. Raimundo sat in the st $\mathrm{rn}$, rigid and silunt; his. eye steadily watch ig the prow of the boat. It was almost wort the risk and dit comfort of the passage tc witness the se manlike: ability displayed by Indians on the water. The little boat rode beautifully, rising weli. with each wave, anc in the course of an hour: and a balf we arrived at Caripí, tzor jughls. tired and wet through to the skin.

On the 16th of January the dry seasur came abruptly to an end. The sez-breezes. which had been increasing in force for some days, suddenly ceased, and the atmosphere. became misty; at length heavy cloads collect. ed where a uniforn. blue sky had $f_{n x}$ many: weeks prevailed, and down came a crecessiom of heavy showers, the first of which asted is whole day and night. This seemed to give a new stimulus to animal life. On the first: night there was : tremendous uprcar -treefrogs, crickets, g at-suckers, and oxls all. joining to perforn a deafening concent. One kind of goat-sucker kept repeating at intervals throughout tze night a phrase sircilar to. the Portuguese we rds, "Joā corta, pro," "John, cut wooc ;" a phrase which forms: the Brazilian narsc of the hird. An owl in: one of the Genipaj)a trees muttered $n: w$ and: then a succession of syllables resemb $\mathrm{ng}$ the word "Murucututú." Sometimes tie croak. ing and hooting of frogs and toads - ere so, loud that we ccild not hear one exsther's. voices within doo:s. Swarms of drag $n$-flies. appeared in the laytime about the pocls of water created by the rain, and ants ard termites came forth in the winged state in vast. numbers. I noticed that the winged termites, or white ants, which came by huncii eds to the. lamps at night, when alighting on the table, often jerked off their wings by a rrituntaiy. movement. On examination. I coved that, the wings were not shed by the roots, for a small portion of the stumps remained attached. to the thorax. The edge of the fracture wass in ull cases straight, net rupture? : there is.. in fact a natural seam rossing in: jnemikr: 
toward its root, and at this point the long wing naturally drops or is jerked off when tle insect has no further use for it. The white ant is endowed with wings simply for the purpose of flying away from the colony peopled by its wingless companions, to pair with individuals of the same or other colonies, sind thus proparate and disseminate its sind. The winged individuals are mules and females, while the great bulk of their wingless fraternity are of no sex, but are of two castes, soldiers and workers, which are restricted to the functions of building the nests, nursing, and defending the young brood. The two sexes mate while on the ground after the wings are shed; and then the married couples, if they escape the numerous enemies which lie in wait for them, proceed to the task of founding new colonies. Ants and white ants bave much that is analogous in their modes of life; they belung, however, to two widely different orders of insects, sliongly contrasted in their structure and manner of growth.

I umassed at Caripí a very large collection of beautiful and curious insects, amounting siltogether to about twelve hundred species. The number of Coleoptera was remarkable, seeing that this order is so poorly represented near Pará. I attributed their abundunce to the number of new clearings made in the vir. gin forest by the native settlers. The felled timber attracts lignivorous insects, aud these draw in their train the predaceous species of various families. As a general rule, the species were smaller and much less brilliaut in colors than those of Mexico and South Brazil. The species too, although numerous were not represented by great numbers of individuals ; they were also extremely nimble, and therefore much less eusy of capture than insects of the same order in temperate climates. The carnivorous beetles at Caripi were, like those of Para, chiefly arboreal. Most of them exhibited a beautiful contriv. ance for enubling them to cling to and run over smooth or flexible surfaces, such as leaves. Their tarsi or feet are broad, and furnished beneath with a brush of short, stiff hairs, while their claws are tonthed in the form of $a$ comb, adapting them for clinging to the smooth edyes of leaves, the joint of the foot which precedes the claw being cleft so as to allow free play to the claw-in grasping. The common dung-beetles at Caripi, which flew about in the evening like the Ge trupes, the familiar " shardborne beetle with his drowsy hum" of our English lanes, were of colossal size and beautiful colors. One kind had a long spear-shaped horn projecting from the crown of its head (Phanæus lancifer). A blow from this fellow, as he came heavily flying along, was never very pleasant. All the tribes of beetles which feed on vegetable substances, fresh or decayed, were very numerous. The most beautiful of these, but not the most common, were the Longicornes, very graceful insects, liaving slender hodies and lung antennæe, of ten ornamented with fringes and tufts of hair. They were found on flowers, on trunks of trees, or flying about the new clearings. One small species (Coremia hirtipes) has a tuft of hair on its hind legs, while many of its sister species have a sim:lar ornament on the antennæ. It suggests curious reflections when we see an ornament like the feather of a grenadier's cap situated on one part of the budy in one species, and in a totally different part in nearly allied ones. I tried in vain to discover the use of these curious brush-like decorations. On the trunk of a living leguminous tree, Petzell found a number of a very rare and handsome species, the Platysternus hebræus, which is of a broad shape, colored ochreous, but spotted and striped with black, so as to resemble a domino. On the felled trunks of trees, swarms of gilded-green Lnngicornes occurred, of small size (Chrysoprasis), which looked like miuiature musk-beetles, and, indeed, are closely allied to those well.known European insects.

At length, on the 12th of February, I left Caripi, my negro and Indian neighbors bid. ding me a warm " adeos." I had passed a delightful time, notwithstunding the many privations undergone in the way of food. The wet season had now set in; the lowlands and islands would soon brcome flooded daily at high water, and the difficulty of obtaining fresh provisions would increase. I intended, therefore, to spend the next three months at Pará, in the neighborhood of which there was still much to be done in the intervals of fine weather, and then start off on another excursion into the in. terior.

\section{CHAPTER VI.}

THE LOWER AMAZONS-PARÁ TO OBYDOS.

Modes of Travelling on the Amazons-Preparations for Voyage-Life on Board a large 'T'rading-vesselThe Narrow Channels joining the Para to the A ma. zons-First sight of the Great River-Gurupá-The Great Shoal-Flat-topped Mountains-SantaremObydos.

Ar the time of my first voyage up the Amazons-namely, in 1819-nearly all communication with the interior was by means of small sailing-vessels, owned by traders residing in the remote towns and villages, who seldom came to Pará themselves, but intrusted vessels and cargoes to the care of half-breeds or Portuguese cabos. Sometimes, indeed, they risked all in the hands of the Indian crew, making the pilot, who was also steersman, do duty as superciryo. Now and then, Portuguese and Brazilian merchants at Pará furnished ycung Portuguese with merchandise, and dispatched them to the interior. to exchunge the goods for produce among the scattered population. The means of com munication, in fact, with the upper parts of the Amazons had been on the decrease for some time, on account of the augmented difficulty of obtaining hunds to navigate vessels. Formerly, when the Government wished to send any important functionary, such as a judge or a military commandant? 
fnto the interior, they equipped a swift-sailing galliota, manued with ten or a dozen Indians. These could travel, on the average, in one day farther than the ordinary suiling craft could in three. Indian paddlers were now, however, almost impossible to be obtained, and Government officers were obliged to travel as passengers in trading-vessels. The voyage made in this way was tedious in the extreme. When the regular east wind blew-the "vento geral," or trade-wind of the Amazons-sailing-vessels could yet along very well; but when this failed they were obliged to remain, sometimes many days together, anchored neac the shore, or progress laboriously by means of tine " espia." The latter mode of travelling was as follows. The montaria, with twenty or thirty tathoms of catse, one end of which was attacned to the foremast, was sent ahead with a couple of hands, who secured the other end of the rope to some strong bough or tree-trunk ; the crew then hauled the vessel up to the point, after which the men in the boat re-embarked the cable, and paddled forward to repeat the process. In the dry season, from Argust to December, when the trade-wind is strong and the currents slack, a schooner could reach the mouth of the Rio Nerro, a thousand miles from Parń, in about forty days; but in the wet season, from January to July, when the east wind no longer biows, and the Amazon pours forth its full volume of water, flooding the bauks and producing a tearing current, it took three mons the travel the same distance. It was a great blessing to the inhabitants when, in 1853 , a line of steamers was established, and this same jour. ney could be accomplished, with ease ind comfort, at all seasons, in eight days !

While preparing for my voyage it happened, fortunately, that the half-brother of Dr. Angelo Custodio, a young mestizo, named Jouō da Cunha Correia, was about starting for the Amazons on a trading expedition in his own vessel, a schooner of about forty tons' burden. A passage for me was soon arranged with him through the intervention of Dr. Angelo, and we started on the 5th of September, 1849. I intended to stup at one village on the northern shore of the Lower Am azons, where it would be interesting to make collections, in order to show the relations of the fauna to those of Para and the coast region of Guiana. As I should have to hire a' house or hut wherever I stayed, I took ail the materials for housekeeping - cooking utensils, crockery, and so furth. To these were added a stock of such provisions as it would be difficult to obtain in the interior also ammunition, chests, store-boxes, a smal library of natural history books, and a hun dred-weight of copper money. I cngaged, after some trouble, a mameluco youth to ac company me as servant-a short, fat, yellowfaced boy named Iuco, whom I had already employed at Pará in collecting. We weighed anchor at night, and, on the following dav, cound nurse!ves gliding along the dark-brown

\section{aters of the Mojú.}

Joaó da Cunha, like most of his fellowcountrymen, took matters very easily. Hewas going $t o$ be absent in the interior severa: years, and therefore intended to diverge irone his route to visit his native place, Carnctá. and spend a few days with his friends. It seemed not to matter to him that he had a cargo of merchandise, ressel, and crew of twelve persons, which required an econom!. cal use of time; "pleasure first and bisiness. afterward "appeared to be his maxim. We stayed at Cametá twelve days. The chier motive for prolonging the stay to this extent was a festival at the Aldeia, two miles below Cametŕ, which was to cumrnence on the 21st, and which my friend wished to take part in. On the day of the festival the schuoner was sent down tu anchor of the Aldeia, and master and men gave themselves up to rev. elry. In the evening a strong breeze sprang up, and orders were given to embark. We scrumbled down in the dark through thethickets of cacao, orange, and coffee trees which clothed the high bank, and, after running great risk of being swamped by the heavy sea in the crowded montaria, got ais aboard by nine o'clock. We made all sail amid the "adeos" shouted to us by Indian. and mulatto sweethearts from the top of the bank, and, tide and wind being favorabie. were soon miles away.

Our crew consisted, as already mentioned. of twelve pe!sons. One was a young Portu. guese from the province of Traz os Montes, a pretty sample of the kind of emigrants: which Portugal sends to Brazil. He was: two or three and twenty years of age, and had been about two years in the country, dressing and living like the Indians, to whom he was certainly inferior in manners. He could not read or write, whereas one at least of our Tapuyos had both accomplishments. He had a little wooden image of Nossa Senhora in his rough wooden clothes-chest, and to this he always had recourse when any squall arose, or when we got aground on a shoal. Another of our sailors was a tawny white of Cametá; the rest were Indians, cxcept the cook, who was a Cafuzo, or half'breed between the Indian and negro. It is often said that this class of mestizos is the most evily disposed of all the numerous crosses between the races inhabiting Brazil : but Luiz was a simple, good-hearted fellow, always ready to do one a service. The pilot. was an old Tapuyo of Pará, with regular oval face and well-shaped features. I was astonished at his endurance. He never quitted the helm night or day, except for two or three hours in the morning. The other Indians used to bring him his coffee and meals and after breakfast one of them relieved bim. for a time, when he used to lie down on the quarter-deck and get his two bours' nap. The Indians forward had things pretty much thes' nwn way. No system of walches was foliowed; when any one was so disposed, he lay down on the deck and we nt to sleep; ius a feeling of good-fellowskip seemed always 
to exist among thom. One of them was a fine specimen of the Indian race-a man very little sliost of six feet high, with remarkable breadih of shoulder and full muscular chest. His comrades called him the commandunt, on account of his having hren one of the rebel leaders when the Indians and others look Sautarem in 1835. Tney related of him that, when the legal authorities arrived with an armed flotilla to recapture the town, he was one of the last to quit, remaining in the little fortress which commands the place to make a show of louding the guns, although the anmunition had given out loug ago. Such were our travelling companions. We lived almost the same as on board ship. Our meals were cooked in the galley ; but, where practicable, and during our numerous stoppages, the men went in the montaria to fish near the shore, so that our breakfasts and dinners of salt pirarecu were sometimes varied with fresh food.

September 24th.-We passed Entre-as-1lhas with the morning tide yesterday, and then made across to the eastern shore - the starting-point for all canoes which have to traverse the broad mouth of the Tocantins, yoing west. Early this morning we commenced the passage. The navigation is attended with danger, on account of the extensive shoals in the middle of the river, which are covered only by a small depth of water at this seasou of the year The wind was fresh, and the schooner rolled and piteher like a hlip at sea. The distance was ahcat fifteen miles. In the middle, the rizer-view was very imposing. Toward the north-eust there was \& long sweep of hrsizin cleur of land, and on the south-wost stretched a similar boundless expanse, but varied with islets clothed with fan-leaved palms, which, however, were visih'e only as isolated yroups of columns, sufted at the top, rising here and there amid ine waste of waters. In the afternoon we rounded the westernmost $p$ sint ; the land, which is not terra firma, but simply a gruup of large islands forming a portion of the Tocantins delta, was theu about three miles distant.

(In the following day (25th) we suiled toward the west, along the upper portion of the Pará estuary, which extends seventy miles beyond the mouth of the Tocantins. It varies in width from three to five miles, but broadens rapidly near its termination, where jt is eight or nine miles wide. The northern shore is forned by the Island of Marajó, and is slightly elevuted and rocky in some parts. A series of islands conceals the southern shore from view most part of the way. The whole country, mainland and islands, is covered with forest. We had a good wind all day, and about seven P.M. entered the narrow river of Breves, which commences ab. ruptly the extensive labyrinth of channels that connects the Para with the Amazons. The sudden termination of the Para, at a point where it expands to so great a breadth, is remarkable ; the water, however, is very shallow uvor the greater portion of the $\mathrm{ex}_{\bar{k}}$ panse. I noticed, both on this and on the three subsequent occasions of passing this place, in ascending and descenciiug the river. that the flow of the tide from the east alon? the estuary, as well as up the Breves, was very strong. This seems sufficient to prov' that no considerable volume of water passe's by this medium from the Amazons to the Pará, and that the opinion of llose geographers is an iucorrect one, who believe tho Pará tu be one of the mouths of the great river. There is, however, another chanuel cinnert ing the two rivers, which enters the Pará sıx miles to the south of the Breves. The luwer part of its course for eighteen miles is form $: 1$ by the Uanapú, a large and independent river flowing from the suuth. The tidal flow is said by the natives tu produce little.or no current up this river-a fact which seems to afford a little support to the view just stated. We passed the village of Breves at threc P.M. on the $26 \mathrm{th}$. It consists of about forty houses, most of which are occupied by Portuguese shopkeepers. A few Indian families reside here, who occupy themselves with the manufacture oi ornamental pottery and painted cuyas, which they sell to traders or passing travellers. The cuyas - drinking cups made from gourds-are sometimes very tastefully painted. The rich black groundcolor is produced by $a$ dye made from the bark of a tree called Comateü, the guinmy nature of which imparts a fine polish. The yellow tints are made with the Tabatinga clay; the red with the seeds of the Urucú, or ana!to plant; and the blue with indigo, which is planterl round the huts. The art is indigenous with the Amazonian Indiaus, but it is only the settled agricultural tribes belonging to the T'upi stock who practise it.

September 27th-30th. - After passing Breves we continued our way slowly along a cliannel, or series of channels, of variable width. On the morning of the 27th we had a fair wind, the breadth of the stream varying from about 150 to 400 yards. About midday we passed, on the western side, the mouth of the Aturiazal, through which, on account of its swifter current, vessels pass in descending from the Amazons to Purá. Shortly afterward we entered the narrow channel of the Jaburú, which lies twenty miles above the mouth of the Breves. Here commences the peculiar scenery of this remarkable regiou. We found ourselves in a narrow and nearly straight canal, not more thun eighty 10 и hundred $y$ ards in width, and hemmed in by two walls of fo est, which rose quite perpendicu. larly from the water to a height of seventy or eighty feet. The water was of great and uniform depth, even close to the banks. We seemed to be in a deep gorge, and the strange impression the place produced was augmented by the dull echoes wakened by the voices of vur Indians and the splash of their paddles. The forest was excessively varied. Some of the trees, the dome-topped giants of the !seguminous and I3ombaceous orders, reared 'heir heads far abuve the average height of .us green walls. The fan-leaved Mirití palm 
was scattered in some numbers amid the rest, a few solitary specimens shooting up their smuoth columns above the other trees. The graceful Assai palm grew in little groups, forming feathery pictures set in the rounder foliage of the mass. The Ubussá, lower in height, showed only its shuttlecockshaped crowns of huge undivided fronds, which, being of a vivid pale-green, contrasted forcibly against the sombre hues of the surrounding foliage. The Ubussú grew here in great numbers; the equally remarkable Tupatí palm (Rhaphia tædigera), which, like the Ubussú, is peculiar to this district, occurred more sparsely, throwing its long shaggy leaves, forty to fifty feet in length, in broad arches over the canal. An infinite diversity of smaller-sized palms decorated the water's edge, such as the Marajá-i (Bactris, many species), the Ubim (Geonoma), and a few stately Bacábas (Enocurpus bacaba). The shape of this last is exceedingly elegant, the size of the crown being in proper proportion to the straight smooth stem. The leaves, down even to the bases of the ylossy petioles, are of a rich dark-green color, and free from spines. "The forest wall "-I am extracting from my journal- " under which we are now moving, consists, besides palms, of a great variety of ordinary forest-trees. From the highest branches of these down to the water sweep ribbons of climbing plants, of the most diverse and ornamental foliage possible. Creeping convolvuli and others have made use of the slender lianas and hanging air-roots as ladders to climb by. Now and then appears a Mimosa or other tree having similar fine pinnate foliage, and thick masses of Ingá border the water, from whose branches hang long bean-pods, of different shape and size, according to the species, some of them a yard in length. Flowers there are very few. I see, now and then, a gorgeous crimson blossum on long spikes ornamenting the sombre foliage toward the summits of the forest. I suppose it to belong to a climber of the Combretaceous order. There are also a few yellow and violet Trumpet-flowers (Bignuniæ). The blossoms of the Ingás, although not conspicuous, are delicately beautiful. The forest all along offers so dense a front that one never obtains a glimpse into the interior of the wilderness."

The length of the Jaburu channel is about 35 miles, allowing for the numerous abrupt bends which occur between the middle and the northern end of its course. We were three days and a half accomplishing the passage. The banks on each side seemed to be composed of hard river-mud, with a thick covering of vegetable mould, so that I should imagine this whole district originateu in a gradual accumulation of ulluvium, through which the endless labyrinths of channels have worked their decp and narrow beds. The flood-tide, as we travelled north ward, became gradually of less assistance to us, as it caused only a feeble current upward. The pressuie of the araters from the Amazons here makes itself fo't. As this is not the case lower down, I suppose the currents are diverted through some of the numerous channels which we passed on our right, and which traverse, in their course, toward the sea, the north-western part of Maraj6. In the evening of the 29th we arrived at a point where another channel joins the Jaburí from the north-east. Up this the tide was flowing: we turned westward, and thus met the flood coming from the Amazons. This point is the object of a strange superstitious observance on the pait of the canoe-men. It is sajd to be haunted by a Pajé, or Indian wizard, whom it is necessary to propitiate, by depositing some article on the spot, if the vorager wishes to secure a safe return from the " sertaô," as the interior of the country is called. The trees were all hung with rags, shirts, straw hats, bunches of fruit, and so forth. Although the superstition dountless originated with the aborigines, yet I observed, in both my voyages, that it was only the Portuguese and uneducated Brazilians who deposited anything. 'The pure Indians gave nothing, and treated the whole affair as a humbug; but they were all civilized Tapuyos.

On the 30 th, at nine P.M., we reached a broad channel called Macaco, and now left the dark, echoing Jaburú. The Macaco sends off branches toward the north-west coast of Marajó. It is merely a passage among a cluster of islands, between which a glimpse is occasionally obtained of the broad waters of the main Amazons. $A$ brisk wind carried us rapidly past its monotonous scenery, and early in the morning of the 1st of October we reached the entrance of the Uituquára, or the Wind-hole, which is $\mathbf{1 5}$ miles distant from the end of the Jaburu. This is also a winding channel, 35 miles in length, threading a group of islands, but it is much narrower than the Macaco.

On emerging from the Uituquára on the $2 d$, we all went ashore-the men to fish in a small creek, Joaó da Cunha and I to shoot birds. We saw a flock of scarlet and blue macaws (Macrocercus macao) feeding on the fruits of a bacaba palm, and looking like a cluster of flaunting banners beneath its darkgreen crown. We landed about fifty yards from the place, and crept cautiously through the forest, but before we reached them they flew off with loud harsh screams. At a wild. fruit tree we were more successful, as my companion shot an anacá (derotypus coronatus), one of the most beautiful of the parrot fumily. It is of a green color, and has a hood of feathers, red bordered with blue, at the back of its liead, which it can elevate or depress at pleasure. The anacá is the only new-world parrot which nearly resembles the cockatoo of Australia. It is found in all the lowlands throughout the Amazons region, but is not a common bird anywhere. Few persons succeed in taming it, and I never saw one that had been taught to speak. The natives are very fond of the bird nevertheless, and keep it in their houses for the sake of seeing the irascible creature expand its beautiful frill of feathors, which it readily does 
when excited. The men returned with a large quantity of fish. I was surprised ut the great variety of species ; the prevailing kind was a species of Loricaria, a foot in length, and wholly encased in bony armor. It abounds at certain seasons in shallow water. The flesh is dry, but very palatable. They brought also a small alligator, which they called Jucaré curúa, and said it was a kind found only in shallow creeks. It was not more than two feet in length, although fullgrown, according to the statement of the In. dians, who said it was a "mui d'ovos," or mother of egg 3 , as they had pillaged the nest, which they had found near the edge of the water. The eggs were rather larger than a hen's, and regularly oval in shape, present. ing a rough hard surface of shell. Unfortunately, the al'igator was cut up ready for cooking when we returned to the schooner, and I could not therefore make i note of its peculiarities. The pieces were skewered and roasted over the fire, each man being his own couk. I never saw this species of alligator afterward.

October $3, x$ - A bout midnight the wind, for which we had long been waiting, sprang up, the men weighed anchor, and we were soon fairly embarked on the Amazons. I rose long before sunrise, to see the great river by moonlight. There was a spanking breeze, and the vessel was bounding gayly over the waters. The channel along which we were sailing was only a narrow arm of the river, about two miles in width; the total breadth at this point is more than twenty miles, but the stream is divided into 1 hree parts by a series of large islands. The river, notwithstanding this limitution of its breadth, had a most majestic appearance. It did not pre. sent that lake-like aspect which the waters of the Pará and Tocantins affect, but had all the swing, so to spoak, of a vast flowing stream. The ochre-culored turbid waters offered also a great contrast to the rivers belonging to the Pará system. The channel formed a splendid reach, sweeping from south-west to north-east, with a horizon of water and sky both up stream and down. At eleven A. M we urrived at Gurupá, a smail village situated on a rocky bank 30 or 40 feet high. Here we landed, and I had an opportunity of rambling in the neighboring woods, which are inlersected by numerous pathways, carpeted with Lycopodia growing to a height of 8 or 10 inches, and enlivened by numbers of glossy blue butterfies of the Theclidæe or hair-streak family. At five P.M. we were again under weigh. Soon after sunset, as we were crossing the mouth of the Xingu, the first of the great tributaries of the Amazons, 1200 miles in length, a black cloud arose suddenly in the north-east. Joaó da Cunba ordered all sails to be taken in, and immediately afterward a furious squall burst forth, tearing the waters into foam, and producing a frightful uproar in the neighboring forests. A drenching rain followed, but in half an hour all was again calm, and the full moon appeared saling in a cloudless sky.

From the mouth of the Xingú the route followed by vessels leads straight across the river, here ten miles broad. Toward mid. night the wind failed us, wher we were close to a large shoal called the Baixo Grande. We lay here hecalned in the sickening heat for two days, and when the trade-wind recommenced with the rising moon at ten P.M. on the 6 th, we found ourselves on a lee-shore. Notwithstanding all the efforts of our pilot. to avoid it, we ran aground. Furtunately, the bottom consisted only of soft mud, so that by casting anchor to windward, and hauling in with the whole strength of crew and passengers, we got off after spending an uncomfortable night. We rounded the point of the shoal in two fathoms water ; the head of the vessel was then put westward, and by sunrise we were bounding forward before a steady breeze, all sail set and everybody in good humor.

The weather was now delightful for several days in succession, the air transparently clear, and the breeze conl and invigorating. At daylight, on the $6 \mathrm{th}$, a chain of blue hills, the Serra de Almeyrim, appeared in the distance, on the north bank of the river. The sight wus most exhilarating after so long a sojourn in a flat country. We kept to the southern shore, passing in the course of the day the mouths of the Urucuricaya and the Aquiquí, two chauncls which communicate with the Xingú. The whole of this southern coast hence to near Santarem, a distance of 130 miles, is lowland and quite uninhabited. It is intersected by short arms or back-waters of the Amazons, which are called in the Tupi language Paraná mirims, or little rivers. By keeping to these, small canves can travel a great purt of the distance without being much exposed to the heary seas of the main river. The cuast throughout has a most desolate aspect ; the forest is not so varied as on the higher land, and the waterfrontage, which is destitute of the green mantle of climbing plants that form Ec rich a decoration in other parts, is encumbered at every step with piles of fallen trees, peopled by white egrets, ghostly storks, and solitary herons. In the evening we passed Almeyrim. The hills, according to Von Martius, who landed here, are about 800 feet above the level of the river, and are thickly wooded to the summit. They commence on the east by a few low, isolated, and rounded eleva. tions; but toward the west of the village they assume the appearance of elongated ridyes, which seem as if they had been planed down to a uniform height by some external force. The next day we passed in succession a series of similar flat-topped hills, some isolated and of a truncated-pyramidal shape, others prolonged to a length of several miles. There is un interval of low country between these and the Almeyrim range, which has a total length of about 25 miles; then cummences abiuptly the Serra de Marauqua, which is succeeded in a simi. bir way by tha Velha Pubie range, the Serras 
de T'apa ana-quára, and Parauá-quára. All these forma a striking contrast to the Serra de Aimesrim in being quite destitute of trees. They save steep rugged sides, apparently clothed with short herbage, but here and there exposing bare white patches. Their total length is about 40 miles. In the rear, tuward the interior. they are succeeded by other ranges of hills, communicating with the ceutral mountain-chain of Guiana, which divides Brazil from Cajenne.

As we sailed along the southern shore, dur. ing the 6th and two following days, the table-topped hills on the opposite side occu. pied most of our attention. The river is from four to five miles broad, and in some places long, low, wooded islands intervene in midstream, whose light - green vivid verdure formed a strangely beautiful foreground to the glorious landsc.pe of broad strem and gray munntain. Ninety miles beyond Almeyrim stands the village of Monte Alegre, which is built uear the summit of the last hill visible of this chain. At this point the river bends a little toward the south, and the hilly country recedes from its shores to reappear at Obydos, greatly decreased in height, about a hundred miles farther west.

We crossed the river three times between Munte Alegra and the next tuwn, Santarem. In the middle the waves ran very high, and the vessel lurched fearfully, hurling everything that was not well secured from one side of the deck to the other. On the murniug of the 9 th of October, a gentle wind carried us alony a " remanso," or still water, under the southern shore. These tracts of quiet water are frequent on the irregular sides of the stream, and are the effect of counter movements caused by the rapid current of its central parts. At nine A.M. we passed the mouth of u Paraná-mirim, called Mahicá, and then found a sudden change in the color of the water and aspect of the banks. Instead of the low and swampy water-frontage which had prevailed from the mouth of the Xingú, we saw before us a broad siuning beach of white sand. The forest, instead of being an entangled mass of irregular and rank vegeta tion as hitherto, presented a rounded outline, and created an impression of repose that was very pleasing. We now approached, in fact, the mouth of the Tapajos, whose clear olive-green waters here replaced the muddy current against which we had so lung been sailing. Although this is a river of great extent-1000 miles in length, and. for the last eighty miles of its course, four to ten in breadth-its contribution to the Amazons is not perceptible in the middle of the stream. The white turbid current of the main river flows disdainfully by, occupying nearly the whole breadth of the channel. while the darker water of its tributary seems to creep along the shore, and is nolonger distinguishable four or five miles from its mouth.

We reached Santarem at 11 A.M. iowns has a clean and cheerful appearance from the river. It consists of three long streets, with a few slo is * es crossing them at right angles, and contains atuout 2500 inhabitants. It lies just within the mouth of the Tapajos, and is divided into two parts, the town and the aldeia or village. The houses of the white and trading classes are substantially built, many being of two and three sturies, and all whitewashed and tiled. The aldeia, which contains the Indian portion of the population, or did so formerly, consists mostly of nud huts, thatched with i palm-leaves. The situation of the town is very beautiful. The land, although but slightly elevated, does not form, strictly speaking, a purtion of the alluvial river plains of the Amazons, but is rather a northern prolongation of the Brazilian continental land. It is scantily wooded, and toward the interior consists of undulating campos, which are connected with a series of hills extending southward as far as the eye can reach. I subsequently made this place my headquarters for three years. An account of its neighburhood is therefore reserved for another chapter. At the first sight of Santarem, one cannot help being struck with the advantages of its situation. Although four hundred miles from the sea, it is accessible to vessels of heavy tonnage coming straight from the Atlantic. The river has only two slight bends between this port and the sea, and for five or six months in the year the Amazonian trade-wind blows with very iittle interruption, so that sailing ships coming from foreign countries could reach the place with little difficulty. We ourselves had accomplished two hundred miles, or about half the distance from the sea, in an ill-rigged vessel, in three days and $a$ half. Although the land in the immediate neighborhood is perhaps ill adapted for agriculture, an immense tract of rich soil, with forest and meadow land, lies on the opposite banks of the river, and the Tapajos leads into the heart of the mining provinces of interior Brazil. But where is the population to come from to develop the resuurces of this fine country? At present the district within a radius of twenty-five miles contains barely 6500 inhabitants ; behind the town, toward the interior, the country is uninhabited, and jaguars roam nightly, at least in the rainy season, close up to the ends of the suburban streets.

From information obtained here, I fixed upon the next town, Obydos, as the best place to stay at a few weeks, in order to investigate the natural productions of the north side of the Lower Amazons. We started at sunrise on the 10th, and being still favored by wind und weather, made a pleasant passage, reaching Obydus, which is nearly fifty miles distant from Santarem, by midnight. We sailed all day close to the suuthern shore, and found the banks here and there dotted with houses of settlers, each surrounded by its plantation of cacao, which is the staple product of the district. This coast has an evil reputation for storms and mosquitoes, but we fortunately escaped both. It was remarkable that we had been troubled by mos. quitoes only on one night, and then to a small 
degre, during the whole of our voyage.

I landed at Obydos the next morning, and then bid adieu to my kind friend Joa o da Cunha, who, after landing my baggage, got up his anchor and coptinued on his way. The town contains aiont 1200 inhabitants, and is airily situated on a high bluff, ninety or oue huncired feet avore the level of the river. The coast is precipitous for two or three miles hence to the west. The cliffs consist of the parti-colned clay, or Tabatinga, which occurs so frequently through. out the Amazons region; the strong current of the river sets full against them in the season of high water, and annually carries away large portions. The clay in places is stratified alternately pink and yellow, the pink beds being the thickest, and of much barder texture than the others. When I descended the river in 1859, a Germun Major of Engineers, in the employ of the Government, told me that he had found calcareous layers, thickly studded with marine shells interstratified with the clay. On the top of the Tabatinga lies a bed of sand, in some places several feet thick, and the whole formation rests on strata of sandstone, which are exposed only when the river reaches its lowest level. Behind the town rises a fine rounded hill, and a range of similar elevations extends six miles westward, terminating at the mnuth of the Trombetus.a large river flowing through the interior of Guiana. Hills and lowlands alike are covered with a sombre rolling forest. The river here is contracted to a breadth of rather less than a mile (1738 rards), and the entire volume of its waters, the collective product of a score of mighty streams, is poured through the strait with trenendous velocity. It must be remarked, however, that the river valley itself is not contracted to this breedth, the opposite shore not being continental land, but a low alluvial tract, subject to inundation more or less in the rainy season. Behind it lies an extensive lake, called the Layo Grande da Ville Franca, which communicates with the $\mathbf{A m a}$. zons buth above and below Obydos, and has therefore the appearance of a liy-water or un old chunnel of the river. This lake is about thirty-five miles in length, and frow four to ten in width; but its waters are of little depth, and in the dry season its dimensions are much lessened. It has no perceptible current, and does not therefore now divert any portion of the waters of the Amazons from their main course past Obydos,

I remained at Obydos from the 11 th of Oc. tober to the 19th of November. I spent three weeks here, also, in 1859 , when the place was much changed, through the influx of Poituguese immigrants and the building of a fortress on the top of the blaff. It is one of the pleusantest towns on the river. The houses are all roofed with tiles, and are mostly of substantial architecture. Must of the Obydos townsfolk are owners of cacao plantations, which are situated on the jowlands in the vicinity. Some are large cattle proprietors, and pcasess estates of muny square leagues' extent in the campos, or srass. land districts, which horder the Lago Grande and other sim.ia* iuland iakes, near the vil: lages of Faro ant Alemquer. These campos bear a crop of nutritious grass; but in cer. tain seasons, when the rising of the Amazons exceeds the average, they are apt to be flooded, and then the large herds of half-wild cattle suffer great mortality from drowning, hunger, and the alligators. Neither in cattle keeping nor cacao-growing are any but the laziest and most primitive methods foilowed, and the consequence is, that the proprieturs are generally poor.

The forest at Obydos seemed to abound in monkeys, for I rarely passed a duy without seeing several. I noticed four species: the Couita (Ateles paniscus), the Chrysothrix sciureus, the Callithrix torquatus, and our old Pará friend, Midas ursulus. The Coaitá is a large black monkey, covered with coarse fair, and laving the prominent parts of the face of a tawny flesh-colored hue. It is the larges: of the Amazonian monkeys in stature, but is excelled in bulk by the "Barrigudo", (Lagothriz Humboldtii) of the Upper Amazons. It occurs throughout the lowlands of the Lower and Upper Amazons; but does not range to the south beyond the limits of the river plains. At that point an allied sp: cies, the white-whiskered Coaita (Ateles marginatus) takes its place. The Coaitás are called by zoolugists spider-monkeys, on account of the length and slenderness of their body and limbs. In these apes the tail, as a prehensible urgan, reaches its highest degree of perfection; and on this account it would, perhaps, be correct to consider the Coaitás as the extreme development of the American type of upes. As for as we know, from living and fossil specie?, the New World has progressed no farth ${ }^{\circ}$ han the Coaitá, toward the production of nigher form of the Quad. rumanous order. The tendency of nature here has been, to all appearance, simply to perfect those organs which adapt the species more and more completely to a purely arboreal life; and no nearcr approach has been inade tow ard the more advanced forms of anthropoid apes, which are the products of the Old World solely. The flesh of this monkey is much estevemed by the uatives in this part of the country, and the military comman. dant at Obydos, Major Gama, every week sent a negro hunter to shoot one for his table. One day I went on a Coaita hunt, borrowing a negro slave of a friend to show me the way. When in the deepest part of a ravine, we heard a rustling sound in the trees overhead, and Manoel soon pointed out a Coaitŕ to me. There wus something humaulike in its appearance, as the lean, dark shaggy creature moved deliberately among the branches at a great height. I fired, but unfortunately only wounded it in the belly. It fell with a crash, headlong, about twenty or thirty feet, and then caught a bough with its tail, which grasped it instantuneously, so that the animal remained suspended in mid. 
adr. Before I cuuld reload it recovered itself, and mounted nimbly to the topmost branches, out of the reach of a fowling-piece, where we could perceive the pour thing apparently probing the wound with its fingers. Coaitás are more frequently kept in a tane state than uny other kind of monkey. The Indians are very fond of them as pets, and the women often suckle them when young at their breasts. They liecome attached to their mas. ters, and will sometimes follow them on the ground to considerable distances. I once sa'v a most ridiculously tame Coaitá. It was an old female, which accompanied its owner, a trader on the river, in all his voyages. By way of giving me a specimen of its intell. gence and feeling, its master set to and rated it soundly, calling it scamp, heathen, thief, and so furth, all through the copious Purtuguese vocabulary of vituperation. The poor munkey, quietly seated nn the ground, seerned to be in sure trouble at this display of anger. It began by looking earnestly at him, then it whined, and lastly rocked its body to and fro with emotion, crying piteously, and passing its long gaunt arms continually over its forehead, for this was its habit when excited, and the front of the head was worn quite bald in consequence. At leugth its master altered his tone. "It's all a lie, my old woman; you're an angel, a tlower, a good affectinaute old sreature," and so forth. Immediately the pour monkey ceased its wailing, and soon after came over to where the man sat. The disposition of the Coaita is mild in the extreme; it has none of the painful, restless vivacity of its kindred, the Cebi, and no trace of the surly, untamable temper of its still nearer relatives, the Mycetes, or howling moukeys. It is, however, un arrant thief, and shows considerable cunning in pilfering small articles of clothing, which it con. ceals in its sleeping-place. The natives of the Upper Amazons procure the Coaitá, when full grown, by shooting it with the blowpipe and poisoned darts, and restoring life by putting a little salt (the antidote to the Urari poison with which the darts are tipped) in its mouth. The animals thus caught become tame forthwith. Two females were once kept ut the Jaidin des Plantes of Paris, and Geoffroy St. Hilaire relates of them that they rarely quitted each other, remaining most part of the time in close embrace, folding their tails round one another's bodies. They took their meals together; and it was remarked on such occasions, when the friendship of animals is put to a hard test, that they never quarrelled or disputed the possession of a favorite fruit with each other.

The neighborhood of Obydos was rich also in insects. In the broad ulleys of the forest a magnificent butterfly of the genus Morpho, six to eight inches in expanse, the Morpho $\mathrm{He}$ cuba, was seen daily gliding along at a heighi of twenty feet or more from the ground. Among the lower trees and bushes numerou? kinds of Helicunii, a group of butterties pe culiar to tropieal America, having Inng nar:row wings, were very abundant. The provailing ground color of the wings of these: insects is a deep black, and on this are de. picted spots and streaks of crimson, white, and bright yellow, in different patterns ac. cording to the species. Their elegant shape, showy colors, aud slow, sailing mode of flight, make them very attractive objects, and their numbers are so great that they form quite a feature in the physiognomy of the forest, compensating for the scarcity of flow. ers. Next to the Heliconii, tise Cata. grammas (C. astarte and C. peristera) were the most conspicuous. These have a very rapid and short flight, settling frequently and remaining stationary for a long time on the trunks of trees. The colors - their wings are vermilion and black, the surt'nce having a rich velvety appearance. The genus owes its Greek name Cutagramma (signifying "a letter beneath") to the curious nivrkings of the underside of the wings, rescmbling Arabic numerals. The species and varieties areof aimost endless diversity, but the majority inhabit the hot valleys of the eastern parts of the Andes. Another butterfly nearly allie 1 to these, Callithea Leprieurii, was also very abundant here, at the marshy head of tho pool before mentioned. The rings are of a rich dark-blue color, with a broad border of silver-green. These two gruups of Callithea and Catagramma are found only in tropical America, chietly near the equator, and aro certainly among the most beautiful produc. tions of a region where the animuls and plants seem to have been fashioned in na. ture's choicest moulds. A yreat variety of other beautiful and curious insects adorned these pleasant woods. Others were seen ouly in the sunshine in open places. As the waters retreated from the beach, vast numbers of sulphur-yellow and orange colored butterflies congregated on the moist saud. The greater portior of them helonged to the genus Callidryas. They assembled in rensely-packed masses, sometimes two or three yards in circumfereuce, their wings all held in an upright position, so that the beach looked as though variegated with beds of crocuses. These Callidryades seem to be migratory insects, und have large powers of dissemination. During the last $i$ wo days of our voyage the great numbers cunstantly passing over the river attracted the attentiun of every one on board. They all crossed in one direction, namely, from north to south, and the processions were uninterrupted from an early hour in the morning untii sunset. All the individuals which resort to the mar. gins of saudy beaches are of the male sex. The females are much more rare, and are seen only on the borders of the forest, wan. dering from tree to tree, and depositing their eggs on low mimusas which grow in the : shade. The migrating hordes, as far as I could ascertain, are composed only of males, and on this account $I$ beieve their wanderiugs do not extend very far.

A strange kind of wood-cricket is iouna in - 
this nelghborhood, the males of which pro. duce a very loud und not unmusical noise by rubbing together the overlapping edges of their wing-cuses. The notes are certainly the loudest and most extraordiuary that I -ever heard produced by an orthopterous insect. The natives call it the Tananá, in allusion to its music, which is a sliarp, resonant stridulation resembling the syllables ta-na-ná, tit-na-ná, succeeding each other with little iutermission. It seems to be rare in the neighborbisod. When the natives capture one, they keep it in a wicker-work cage for the sake of hearing it sing. A friend of mine kept one six days. It was lively only for two or three, and then its loud note could be heard from one end of the village to the other. When it died, he gave me the specimen, the only one I was able to procure. It is a member of the family Isucustidæ, a group intermediate between the Crickets (Achetidæ) and the Grasshoppers (Acridiidæ). The total length of the body is two inches and a quarter; when the wings are closed, the insect has an inflated vesicular or bladder-like shape, owing to the great convexity of the thin, but firm, parchmenty wing-cases, and the color is wholly pale green. The instrument by which the Tananá produces its music is curiously contrived out of the ordinary nervures of the wing-cases. In each wing-case the inner edge, near its origin, has a horuy expansion or lobe ; on one wing $(b)$ this lobe has sharp raised margins; on the other $(a)$, the strong nervure which traverses the lobe on the other side is crossed by a number of fine sharp furrows like those of a file. When the insect rapidly moves its wings, the file of the one lohe is scraped -sharply across the horny margin of the other, thus producing the sounds, the parchmenty wing-cases and the hollow drum-like space which they enclose assisting to give resonance to the tones. The projecting portions of both wing cases are traversed by a similar strong nervure, but this is scored like a file only in one of them. in the other remaining perfectly nooth. Other species of the fumily to which the Tanana belongs have similar stridulating organs, but in none are these so highly developed as in this insect; they ex. ist always in the males only, the other sex having the edges of the wing-cases quite straight and simple. The mode of producing the sounds, and their object, have been investigated by several authors with regard to certain European species. They are the call-notes of the tnules. In the common field-cricket of Europe, the male has been observed to place itself, in the evening, at the - entrance of its burrow, and stridulate until a female approaches, when the louder notes are succeeded by a more subdued tone, while the successful musician caresses with his artennæ the mate he has won. Any one who, will take the triuble, may observe a similar proceeding in the common housc-cricket. The nature and object of this insect music are more uniform than the structure and situation of the instrument by which it. is pro- duced. This differs in each of the three allied families above mentiored. In the crickets the wing-cases are symmetrical; both have straight edges and sharpiy scored nervures adapted to produce the stridulation. A distinct portion of their edyes is not, therefore, set apart for the elaboration of a sound. produoing instrument. In this family the wing-cases lie flat on the back of the insect, and overlap each other for a considerable portion of their extent. In the Locustidæ the same members have a sloping position on each side of the body, and do not overlap, except to a small extent near their bases; it is out of this small portion that the stridu. lating organ is contrived. Grealer resonance is given in most species by a thin transparent plate, covered by a membrane, in the centre of the overlapping lobes. In the Grasshop. pers (Acridiidæ) the wing-cases meet in a straight suture, and the friction of portions of their edges is no longer possible. But na. ture exhibits the same fertility of resource here as elsewhere; and, in contriving other methods of supplying the males with an in. strument for the production of call-notes, indicates the great importance which she at. taches to this function. The music in the males of the Acridiidæ is produced by the scraping of the long hind thighs against the horny nervures of the outer edges of the wing-cases, a drum-shaped organ placed in a cavity near the insertion of the thighs being adapted to give resunance to the tones.

I obtained very few birds at Obydos. There was no scarcity of birds, but they were mostly common Cayenue species. In early morning the woods near my house were quite animated with their songs-an unusual thing in this country. I heard here for the first time the pleasing wild notes of the Carashué, a species of wild thrush, probably the Mimus lividus of ornithologists. I found it afterward to be a common bird in the scattered woods of the campo district near Santarem. It is a much smaller and plainer-colored hird than our thrush, and its song is not so loud, varied, or so long sustained; but the tppe is of a sweet and plaintive quality, which harmonizes well with the wild and silent woodlands, where alone it is heard, in the mornings and evenings of sultry tropical days. In course of time the song of this humble thrush stirred up pleasing associations in my mind, in the same way as those of its more highly. endowed congeners formerly did at home. There are several allied species in Brazil ; in the southern provinces they are called Sabiahs. The Brazilians are not insensible to the charms of this their best songster, for I often heard some pretty verses in praise of the Sabiah, sung by.young people to the accompaniment of the guitar. I found severul times the nest of the Carashué, which is built of dried grass and slender twigs, und liued with mud; the egys are colored and spotted like thuse of our blackhird, but they are cus. siderably smaller. I was much pleased with a brillant little red-headed mannikin whicb I shot here (Pipra cornuta). There wero 
three males seated on a low branch, and hopping slowly backward and forward, near to one another, as though engaged in a kind of dance. In the pleasant airy woods surrounding the sandy shores of the pool behind the town, the yellow-bellied Trogon ( $T$. viridis) was very commun. Its back is of a brilliant metallic green color, and the breast steel b?ue. The natives call it the Suruquá do Ygapó, or Trogon of the flooded lands, in contradistinction to the various red-breasted species, which are named Suruquás da terra firma. I often saw small companies of half a dozen individuals, quietly seated on the lower branches of trees. They remained almost motionless for an hour or two at a time, simply moving their heads, on the watch for passing insects, or, as seemed more generally to be the case, scanning the neighboring trees for fruit, which they dart off now and then, at long intervals, to secure, returning always to the same perch.

\section{CHAPTER VII.}

THE LOWER AMAZONS-OBYDOS TO MANAOS, OR TIE BARRA OF THE RIO NEGRO.

Departure from Obydos-River Banks and By-channels-Cacao Planters-Daily Life on Board our Ves. sel-Great Storm-sand Island and its Birds-Hill of Parentins-Negro Trader and Mauhés IndiansVilla Nova, its Inhabitants, Forest, and Animal Productions-Cararauch-A Rustic Festival-Lake of Cararaucú - Motúca Files - Serpa-Christmas Holidays-River Madeira-A Mamelnco FarmerMura Indians-Rio Negro-Description of BarraDesceut to Pará-Yellow Fever.

A Trader of Obydos, uamed Menna, was ubout proceeding in a cuberta laden with merchandise to the Rio Negro, intending to stop frequently on the road, so I bargained with him for a passage. He gave up a part of the toldlo, or fore-cabin as it may be called, anc here I slung my hammock and arranged my boxes, so as to be able to work as we went along. The stoppages I thought would be an advantage, as ' $I$ could collect in the woods while he traded, and thus acquire a knowledge of the productions of many places on the river which, in a direct voyage, it would be impossible to do. I provided a stock of groceries for two months' consumption ; and, after the usual amount of unnecessary fuss and delay on the part of the owner, we started on the 19th of November. Penna took his family with him; this comprised a smart, lively mameluco woman, named, Caturina, whom we called Senhora Katita. and two children. The crew consisted of three men, one a sturdy Indian, another a Cafuzo, godson of Penna, and the third, our best hancl, a steady, good-natured mulatto, named Joaquim. My boy Luco was to assist in rowing and so forth. Penna was a timid middle-aged man, a white with a slight cross vi Indian; when he was surly and obstinate, he used to ask me to excuse him on accoun of the Tapuyo bluod in his veins. He tried to make me as comfortable as the circumstances ad_nitted, and provided a large stock of eatables and drinkables ; so that altogether the voyage promised tu be a lluase ant one.

On leaving the port of Obydos we crossed over to the right bank, and sailed with a light wind all day, passing numerous houses, each surrounded by its gruve of cacao trees. On the 20 th we made sluw progress. After passing the high land at the mouth of the Trombetis, the banks were low, clcyey, or earthy on both sides. The breadth of the river varies hereabout from two and a half to three miles, but neither coast is the true terra firma. On the not thern side a by-channel runs for a long distance inland, conmunicating with the extensive lake of Faro; on the south, three channels lead to the similar fresh water sea of Villa Frunca; these are in part arms of the river, so that the land they surround consists, properly speaking, of islands. When this description of land is not formed wholly of river deposit, as sometimes happens, or is raised above the level of the highest floods, it is called Yyapo alto, and is distinguished by the natives from the true islunds of mid-river, as well as from the terra firma. We landed at one of the cacao plantations. The house was sulstantially built; the walls formed of strong upright posts, lathed across, plastered with mud, and whitewashed, and the roof tiled. The family were mamelucos, and seemed to be un average sample of the poorer class of cacau-grow. ers. All were loosely dressed and barefooted A broad veranda extended along one sido of the house, the floor of which was simply the well-trodden earth : and here hammocks were slung between the bare upright supports, a large rush mat being spread on the ground, upa, which the stout matron-like mistress, with a tame parrot perched upon her shoulder, sat sewing with two pretty little mulatto girls. The master, coolly clad in shirt and draweis, the former loose about the neck, lay in his hammock smoking a long, gaudily-painted wooden pipe. The household utensils, earthenware jars, water-pots, and saucepans, lay at one end, near which was a wood fire, with the ever-ready coffeepot simmering on the top of a clay tripod. A large shed stood a short distance off, em. bowered in a grove of banana, papaw, and. mango trees; and under it were the oveus, troughs, sieves, and all other apparatus for the preparation of mandioca. The cleared space around the house was only a few yaids in extent; beyond it lay the cacao piantistions, which stretched on each sile parallel to the banks of the river. There was a path through the forest which led to the mandioca fields, and several miles beyord to other houses on the banks of an interior channel. We were kindly received, as is always the case when a stranger visits these out-of-theway habitations, the people being invariably civil and hospitable. We had a long chat, took coffee, and on departing one of the daughters sent a basketful of oranges for our use down to the canoe.

The cost of a cacao plantation in the Obydos district is after the rate of 240 ieis of: 
sixpence per tree, which is much higher than at Cameta. where I believe the yicld is not so great. The forest here is cleared before planting, and the trees were gruwn in rows. The smaller cultivators are all very poor. Labur is scarce; one fumily generally manarges its own small plantation of 10,000 to 15,000 trees, lout at the harvest time neigh. bors assist each other. It appeared to me tc be an easy, pleasant life; the work is all done under shade, anc occupies nuly a few weeks in the year. The incorrigible nonchslance and laziness of the people alone prevent them from surrounding themselves with all the luxuries of a tropical country. They might plant orchards of the choicest fruittrees around their houses, grow Indian corn, and rear cattle and hogs, us intelligent settlers from Europe would certainly do, instead of indolently relying solely on the produce of their small plantations, and living on a meagre diet of fish and farinha. In preparing the cacau they have not devised any means of separating the seed well from the pulp, or arying it in a systematic way ; the consequence is that, although naturally of guod quality, it moulds before reaching the merchants' stores, and does not fetch mure than half the price of the same article grown in other parts of tropical America. The Amazons regrion is the original home of the princ:pal species of chocolate tree, the Thenbroma cacuo ; and it grows in abundance in the forests of the upper river. The cultivated crop appears to be a precarious one ; little or no care, however, is bestowed on the trees, and even weeding is done very inefficiently. The plantations are generally old, and have been made on the low ground near the river, which renders them liable to inundation when this rises a few inches more than the average. There is plenty of higher land quite suitable to the tree, but it is un. cleared, and the want of labor and enterprise prevents the establishment of new plantations.

We passed the last houses in the Obydos district on the 20 th, and the river scenery then resumed its usual wild and solitary character, which the scattered human habitations relieved, although in a small degree. We soon fell into a regular inode of life on board our little ark. Penua would not travel by night ; indeed, our sinall crew, wearied by the day's labor, required rest, and we very rarely had wind in the night. We used to moor the vessel to a tree, giving out plenty of cable, so as to sleep at a distance frum the banks and free of mosquitues, which although swarming in the forest, rarely tame many yards out into the river at this season of the year. The strong current, at a distance of thirty or forty yards from the coast, steadied the cuberta head to stream, and kept us from drifting ashore. We all slept in the open air, as the heat of the cabins was stifling in the carly part of the night. Penna, Seuhora Katita, and I, slung out hammocks in triangle between the mainmast and two stout poles fixed in the ruised dock.
A sheet was the only covering requirea, be. sides our regular clothing; for the decrease of temperature at, night on the Amazons i uever so great as to be felt otherwise than as a delightful coolness, after the sweltering heat of the aiternoons. We used to rise when the first gleam of dawn slowed itself above the long dark line of forest. Our clothes and hammocks were then generally soaked with dew, but this was not felt to be un inconvenience. The Indian Manoel used to revive himself by a plunge in the river, under the bows of the vessel. It is the habit of all Iudians, male and female, to bathe early in the morning ; they do it sumetimes for warmth's sake, the temperature of the water being often considerably higher than that of the air. Penna and I lolled in our hammocks, while Katita prepared the indis. pensable cup of strong coffee, which she did with wonderful celerity, smoking mean while her early morning pipe of tobacco. Liberal owners of river craft allow a cup of coffee sweetened with molasses, or a ration of cashaça, to each man of their crews ; Penna gave them coffee. When all were served, the day's work begran. There was seldorn any wind at this early hour; so if there was still water along the shore the men rowed, if not, there was no wry of progressing but by espia. In some places the currents ran with great force close to the banks, especially where these receded to form long bays or enseadas, as they are called, and then we made very little headway. In such places the banks consist of loose earth, a rich crum. bly vegetable mould. supporting a growth of most luxuriant forest, of which the currents almost daily carry away large portions. so that the strearn for several yards out is incumbered with fallen trees. whose branches quiver in the current. When projecting puints of land were encountered, it was impossible, with our weak crew, to pull the cuberta against the whirling torrents which set round them; and in such cases we had to cross the river, driftiug often with the cur. rent, a mi or two lower down on the oppo. site shore. There generally sprung up a light wind as tho day advanced, and then we took down our hammocks, hoisted all sail, and bowled away merrily. Penna generally preferred to cook the dinner ashore, when there was little or no wind. About mid-day on these calm days we used to look out for a nice shady nook in the furest, with cleared space sufficient to make a tire upon. I then had an hour's hunting in the neighloning wilderness, and was always rewarded by tile discovery of some new species. During the greater part of our voyage, however, we stopped at the house of soine settler, and made our fire in the port. Just before dinner it was our habit to take a bath in the river, and then, according to the universal custom on the Amazons, where it seems to be suitable on account of the weak fish diet, we each took half a teacupful of neat cashaça, the " abre" or " opening," as it is. called, and set to on n" wess of stewed. 
pirarect, beans, and bacon. Once or twice za week we had fowls and rice; at supper, after sunset, we of ten had fresh fish caught by our men in the evening. The mornings were cool and pleasant until toward midday; but in the afternoons the lieat becume almost intolerable, especially in gleamy, ssqually weather, such as generally prevailed. We then cronched in the shade of the sails, or went dowu to our hanmocks in the cabin, achoosing to be half stifled rather than expose ourselves on deck to the sickening heat of the sun. We generally ceased travelling about nine o'clock, fixing upon a safe spot wherein to secure the vessel for the night. The cool evening hours were delicions; flocks of whistling ducks (Anas autumnalis), parrots, and hoarsely - screaming macaws, pair by pair, flew cver from their feeding to their resting places, as the glowing sun plunged abruptly beseath the horizon. The brief evening chorus of animals then began, the chief performers being the howling monkeys, whose friglitful unearthly roar deepened the feeling of solitude which crept on as darkness closed around us. Soon after, the fireflies in great diversity of species cume forth and flitted about the trees. $\Lambda$ s night advanced, ull became silent in the forest, save the occasional hooting of tree-frogs, or the monotonous chirping of wood-crickets zand grasshoppers.

We made but little progress on the 20th and two following days, on account of the unsteadiness of the wind. The dry season laad been of very brief duration this year; it generally lasts in this part of the Amazons from Jily to January, with a short interval of show ery wes. $r$ in November. The river ought to sink thirty or thirty-five feet below its highest point; this year it had declined only about twenty-five feet, and the November rains threatened to be continuous. The drier the weather, the stronger blows the east wind; it now failed us altogether, or blew gently for a few hours merely in the afternoons. I had hitherto scen the great river only in its sunniest aspect; I was now about to witness what it could furnish in the way of storms.

Gn the night of the 22d the moon appeared with a misty halo. As we went to rest, a fresh watery wind was blowing, und a dark piie of clouds gathering up river in a direction opposite to that of the wind. I thought this betokened nothing more than a heavy rain, which would serd us ull in a hurry to our cabins. The men moored the ressel to a tree alongside a laurd cluj ey bank, and efter supper all were soon fast asleep, iscattcred about the raised deck. About eleven o'clock I was awakened by a horrible uproar, as a hurricane of wind suddenly swept over from the opposite shore. The cuberta was hurled with force against the clayey hank; Penna shouted out, as he started to his legs, that a trovoada de cima, or a squall from up river, was upon us. We took down our hammocks, and then all bands were required to save the vessel from being dashed to pieces. The moon set, and a black pall of niouds spread itself over the dark forests and river ; a frigittful crack of thunder now bursts over our heads, and down fell the drenching rain. Jouquim leaped ashore through the drowning spray with a strong pole, and tried to pass the cuberta round a small projecting point, while we on deck aided in kreping her off and lengthened the calle. We succeeded in getting free, and the stout-built boat fell off into the strong current farther away from the shore, Joaquim swinging himself dexterously zboard by the bowsprit as it passed the point. It was foitunate for us that we happened to be on a sloping clayey bank, where there was no fear of falling trees; a few yards farther on, where the shore was perpendicular and formed of crumbly earth, large portions of loose soil, with all their superincum. bent mass of forest, were being washed away; the uproar thus occasioned adding to the horrors of the storm.

The violence of the wind abated in the course of an hour, but the deluge of ruin continued until about three o'r.lock in the morning; the sky being lighted up by almost incessant flashes of pallid lightning, and the thunder pealing from side to side without interruption. Our clothing, hammocks, and gnods were thoroughly soaked by the streams of water which trickled through het ween the planks. In the morning all was quiet ; hut an opaque, leaden mass of clouds overspread the sky, throwing a gloom over the wild landscape that had a most dispiriting effect. These squalls from the west are always pxpected about the time of the break. ing up of the dry season, in these central parts of the Lower Amazons. They generally take place about the beginning of $\mathrm{Feb}$. ruary, so that this year they had commenced much earlier than usual. The soil and climate are much drier in this part of the coun. try than in the region lying farther to the west, where the denser forests and more clayey, hunid soil produce a considerably cooler atmosiphere. The storms may be therefore uttributed to the rush of cold moist air from up river. when the regular tradewind coming from the sea has slackened or ceased to blow.

On the $26 \mathrm{th}$ we arrived at a large sandbank connected with an island in mid-river. in front of an inlet called Maracíuassí. Here we anchored and spent half $\mathbf{a}$ day ashore. Penna's object in stopping was $\leqslant \mathrm{m}$. ply to enjoy a ramble on the sands with the children, and give Senhora Katita an opportunity to wash the linen. The sund-kank was now fast going under water with the rise of the river; in the middle of the dry season iv is about a mile long and half a mile in width. The canoe-men delight in these open spaces, which are a great relief to the munotony of the forest that clothes the land in every other part of the river. Farther westward they are much more frequent, and of larger extent. They lie generally at the upper end of islauds; in fact, the latter originate in ac- 
sretions of vegetable matter, formed by plants and trees growing on a shoal. Thu island was wooded chiefly with the trumpettree (Cecropia peltata), which has a hollow stem and sinuoth pale bark. The leaves are similar in shape to those of the horse-chestnut, but immensely larger; beneath they are white, and when the welcome trade-wind blows they show their silvery under sides-a pleasant signal to the weary canoe traveller. The mode of growth of this tree is curious: the branches are emitted at nearly right angles with the stem, the branchlets in minor whorls around these, and so forth, the leaves growing at their extremities; so that the total appearance is that of a huge candelabrum. Cecropiæ of different species are charactoristic of Brazilian forest scenery ; the kind of which I am speaking grows in great numbers everywhere on the banks of the Amazons where the land is low. In the same places the curious monguba-tree (Bombax ceiba) is also plentiful ; the dark-green bark of its huge tapering trunk, scored with gray, forming a conspicuous object. The principal palm-tree on the lowlands is the Juuari (Astryocaryum Jauarí), whose stem, surrounded by whorls of spines, shoots up to a great height. On the borders of the island were large tracts of arrow-grass (Gynerium saccharoides), which bears elegant plumes of feathers, like those of the reed, and grows to a height of twenty feet, the leaves arranged in a fan-shaped figure near the middle of the stem. I was surprised to find on the higher parts of the sand bank the familiar foliage of a willow (Salix Humboldtiana). It is a dwarf species, and grows in patches resembling beds of osiers; as in the English willows, the leaves were peopled bysmall chrys. omelideous beetles. In wandering about, many features reminded me of the sea-shore. Flocks of white gulls were flying overhead, uttering their well-known cry, and sandpipers coursed along the edge of the water. Here and there loncly wading-birds were stalking about; one of these, the Curicáca (Ibis melanopis), flew up with a low cackling noise, and was soon joined by an unicornbird (Palamedea cornuta), which I startled up from amid the bushes, whose harsh screams, resembling the bray of a jackass, but shriller, disturbed unpleasantly the solitude of the place. Among the willow-bushes were flecks of a handsome bird belonging to the Icteridæ or troupial family, adorned with a rich plumage of black and saffron-yellow. I spent some time watching an assemblage of a species of bird called by the natives Tamburi-pari, on the cecropia-trees. It is the Monasa nigrifrons of ornitbologists, and has a plain slicie-colored plumage, with the beak of an orange hue. It belongs to the family of Barbets, most of whose members are re. markable for their dull, inactive temperament. Those species which are arranged by orni. thologists under the genus Bucco are called by the Indians, in the Tupi language, Taiessú uirá, or pig-birds. They remain seated cometimes for hours together on low brauches in the shade, and are stimulated to exertion only when attracted by passing insects. This flock of Tamburi-para were the reverse of dull ; they were gamboling and chasing each other among the branches. As they sported about, each emitted a few short tune. ful notes, which altogether produced a ring. ing, musical chorus that quite surprised me.

On the 27th we reached an elevated wood. en promontory, cailed Parentins, which now forms the boundary between the provinces of Pará and the Amazons. Here we met $u$ small canoe descending to Santarem. The owner was a free negro named Lima, who, with his wife, was going down the river to exchange his year's crop of tobacco for European merchaudise. The long shallow canoe was laden nearly to the water level. He resided on the banks of the Abacaxi, a river which discharges its waters into the Canomá, a broad interior channel which extends from the river Madeira to the Parentins, a distance of 180 miles. Penna offered him advantage. ous terms, so a bargain was struck, and the man saved his long journey. 'T'he neyro seemed a frank, straightforward fellow; he was a native of Pernambuco, but had settled many years ago in this part of the country. He had with him a little Indian girl belong. ing to the Mauhés tribe, whose native seat is the district of country lying in the rear of the Canomá, between the Madeira and the Tapajos. The Mauhés are considered, I think with truth, to be a branch of the great Mundurucú nation, having segregated from them at a remote period, and by long isolation acquired different customs and a totally different language, in a manner which seems to have been general with the Brazilinn aborigines. The Mundurucús seem to have retained more of the general characteristics of the original Tupí stock than the Mauhes. Senhor Lima told me, what I afterward found to be correct, that there were scarcely two words alike in the languages of the two people, although there are words closely allied to Tupi in both. The little girl had not the slightest trace of the savage in her appearance. Her features were finely shaped, the cheek-bones not at all prominent, the lips thin, and the expression of ber countenunce frank and smiling. She had been brought only a few weeks previously from a remote settlement of her tribe on the banks of the Abacaxí, and did not yet know five words of Portuguese. The Indians, as a general rule, are very manageable when they are young, but it is a frequent complaint that when they reach the age of puberty they become restless and discontented. The rooted impatience of all restraint then shows itself, and the kindest treatment will not prevent them running away from their masters; they do not return to the malocas of their tribes, but join parties who gu out to collect the prod. uce of the forests and rivers, and lead a wandering, semi-savage kind of life.

We remained under the Serra dos Parentins all night. Early the next morning a light mist liung about the tree-tops, and the forest. 
resounded with the yelping of Whaiápu-sai monizeys. I went ashore with my gun and yot a glimpse of the fl sck, but did not succeed in nbtaining a specinen. They were of small sime and covered with long fur of a uniform gray color. I think the species was the Callithrix donacophilus. The rock composing the elevated ridge of the Parentius is the silme coarse iron-cemented eonglomerate which I have often spoken of as occurring zucar Purú and in several other places. Many Jouse blocks were scattered about. The forest was extremely viried, and inextricable coils of woody climbers stretched from tree to tree. Thongs of cacti were spread over the rocks and trec-trunks. The variety of small, beautifully-sinaped ferus, lichens, and buleti made the place quite a museum of eryptogamic plants. I found here two exquisite species of Longicorn beetles, and a lurge kind of grasshopper (Pterochroza), wliose broad fore-wings resembier the leaf of a plant, providing the insect with a perfect disguise when they were closed; while the hind wings were decorated with gaylyculored eye-lıke spots.

The negro left us and turued up a narrow channel, the Parana-mirim dos Ramos (the little river of the branches, i.e., having many ramifications), on the road to his home, 130 iniles distant. We then continued uur voy: age, and in the evening arrived at Villa Nova, a straggling village containing about seventy houses, miany of which scarcely deserve the name, being mere mud-huts roofed with palm-leaves. We stayed here four days. The village is built on a rocky bank, cumposed of the same coarse conglomerate as that already so often mentioned. In some places a bed of Tabatinga clay rests on the conglomerate. The soil in the neighbor hood is sandy, and the forest, most of which appears to be of second growth, is traversed by broad alleys which terminate to the south and east on the banks of pouls and lakes, a chain of which extends through the interior of the land. As sosn as we anchored I set off with Luco to explore the district. We walked about a mile along the marly shore, on which was a thick carpet of flowering shrubs, enlivened by a great variety of lovely little butterflies, and then entered the forest iy a dry water-course. About a furlong inland this opened on a broad placid pool, whose banks, clothed with grass of the softest green hue, sloped gently from the water's vilge to the compact wall of forest which encompassed the whole. The pool swarmed with water-fowl-snowy egrets, dark-colored striped herons, and storks uf various species standing in rows around its margins. Small flocks of macaws were stirring about the topmost brenches of the trees. Long-legged piosócas (Parra Jacana) stalked over the Water-plants on the surface of the pooi, and in the bushes on its margin were great num. bers of a kind of canary (Sycalis brasiliensis) of a greenish-yellow color, which has a short and not very melodious song. We had advanced but a few steps when we startited a. pair of the Jaburú-moleque (Mycteria americana), a powerful bird of the stork family, four and it half feet in height, which flew us and alarmed the rest, so that I got only one bird out of the tumultuous flocks which passed over our heads. Passing toward the farther end of the pool, I saw, resting on the surface of the water, a number of large round leaves, turned up at their edges; they belonged to the Victoria water-lily. The leaves were just beginning to expand (December $3 d)$, sume were still under water, aud the largest of those which had reached the surface measurerl not quite three feet in diameter. We found a montaria with a paddle in it, drawn up on the bank, which I took leare to borrow of the unknown owner, and Laco paddled nie amung the noble plants to search for flowers, meeting, however, with no success. I learned afterward that the plant is common in nearly all the lakes of this neigh. borbood. The natives call it the furno do Piosoca, or oven of the Jacana, the shape of the leaves being like that of the ovens on which nandioca-meal is roasted. We saw many kinds of hawks and eagles, one of which, a black species, the C'aracára-í (Mil. vago nudicollis), sat on the top of a tall naked stump, uttering its hypocritical whining notes. This eagle is considered a bird of ill omen by the Indians; it often perches on the tops of trees in the neighborhuod of their huts, and is then said to bring a warning of death to some member of the household. Others say that its whining cry is intended to attract other defenceless birds within its reach. The little courageous flycatcher Bem-ti-vi (Sauroplaagus sulphuratus) assem. bles in companies of four or five, and attacks it boldly, driving it from the perch where it would otherwise sit for hours. I shot three hawks of as many different species; and these, with a Magoary stork, two beautiful gilded-green jacamars (Albula chalcocephala), and half a dozen leaves of the water-lily, made a heary load, with which we trudged off back to the canoe.

A few years after this visit, namely, in 1854-5, I passed eight months at Villa Nova. The district of which it is the chief town is very extensive, for it has about forty miles of linear extent along the banks of the river ; but the whole does not contain more than 4000 inhabitants. More than half of these are pure-blood Indians, who live in a sem. civilized condition on the banks of the numerous chanuels and lakes. The trade of the place is chiefly in india-rubber, balsam of copaiba (which are collected on the banks of the Madeira and the numerous rivers that enter the Canomá channel), and salt fish prepared in the dry season, nearer lome. These articles are seut to Pará in exchange for European goods. The few Indian and halfbreed families who reside in the town aro many shades inferior in personal qualitics and sucial condition to those I lived among near Pará and C'rmetá. They live in wretched dilapidated mud-hovels; the women cultivate small patches of mandioca. the 
men spend most of their time in fishing, selling what they do not require thenselves, and getting drunk with the most exemplary regularity on cushaça, purchased with the proceeds.

I made, in this second visit to Tilla Nova, an extensive collection of the natural productions of the neighborhood. A few remarks on some of the more interesting of these must suffice. The forests are very different in their general character from those of Para, and in fact those of luumid districts. generally throughout the Amazons. The same scarcity of large-leaved Musaceous and Murantaceous plants was noticeuble here as at Obydos. The low-lying areas of forest or Ygapos, which alternate everywhere with the more elevated districts, did not furnish the same luxuriant vegetation as they do in the Dolta region of the Amazons. They are flooded during three or four months in the year, and when the waters retire, the soil-to which the very thin coating of alluvial deposit imparts little fertility-remains bare, or covered with a matted bed of dead leaves, until the next flood season. These tracts have then a barren appearance; the trunks and lower branches of the trees are coated with dried slime, and disfigured by rounded masses of fresli-water sponges, whose long horny spicula and dingy colors give them the appearance of hedgehogs. Dense bushes of a harsli, cutting grass, called Tiriríca, form almost the only fresh vegetation in tho dry seuson. Perhaps the dense shade, the loug period during which the land remains under water, and the excessively rapid desiccation when the waters retire, all contribute to the barrenness of these Ygapos. The higher and drier land is everywhere sandy, and tall coarse yrasses line the borders of the broad alleys which have been cut through the second-growth woods. These places swarm with carapitos, ugly ticks belonging to the genus Ixodes, which mount to the tips of blades of grass, and attach themselves to the clothes of passers-by. They are a yreat annoyance. It occupied me a full lour daily to pick them off my flesh atter my diur. nal ramble. There are two species; both are much flattened in shape, have four pairs of legs, a thick, short proboscis, and a horny integument. Their habit is to attach them. selves to the skin by plunging their proboscides into it, and then suck the blood until their flat bodies are distended into a globular form. The whole proceeding, however, is very slow, und it takes them several duys to pump their fill. No pain or itching is felt, but serious sores are caused if care is not taken in remuving them, as the proboscis is liable o break off and remain in the wound. A little tobacco-juice is generally applied to make them loosen their hold. They do not cling firmly to the skin by their iegs, ulthough each of these has a pair of shmrp and fine claws, connected with the tips of the member by means of a flexible pedicle. When they mount to the summits of slender liludes of grass, or the tips of leaves, they hold on, by their fore-legs only, the other three pairs being stretched out so as to fasten on any animal which comes in their way. The smaller of the two species is of a yellowish color ; it is much the most abundant, and sometimes falls upon one by scores. When distended, it is about the size of a No. 8 . shot; the larger kind, which fortunately comes only singly to the work, swells to the size of a per.

In some parts of the interior the soil is composed of very coarse sand and small frag ments of quartz; in these places no trees grow. I visited, in company with the priest, Padre Turquato, one of these treeless spaces. or campos, as they are called, situated five miles from the village. The road thither led. through a varied and beautiful forest, containing many gigantic trees. I missed the Assai, Mirití, Paxiúba, and other palms. which are all found ouly on rich inoist soils, but the noble Bacába was not uncommon, and there was a great diversity of dwarf species of Marajá palms (Bactris), one of which. called the Peuririma, was very elegant, growing to a height of twelve or fifteen feet, with a stem no thicker than a man's finger. On arriving at the cumpo, all this beautiful forest abruptly ceased, and we saw before us. an oval tract of land, three or fuur wiles in. circumference, destitute even of the smallest. bush. The only vegetation was a crop of coarse hairy grass growing in patches. The. forest formed a hedge all round the isolated field, and its borders were composed in great. part of trees which do not grow in the dense: virgin forest, such as a great varicty of bushy Melastomas, low Byrsumiua trees, myrtles, and Lacre trees, whose beriies exude globules of wax resembling gamboge. On the margins of the campo wild piueapples also grew in great quantity. The fruit was of the same: shape as out cultivated kind, but mucle. smaller, the size being that of a nutlerately large apple. We gatherel severul quite ripe; they were pleasant to the taste, of the true pineapple flitvor, but had an abundance of fully developed seeds, and only a small quantity of eatable pulp. There was no path beyond this campo ; in fact, all beyond is terra. incognita to the inhabitants of Villa Nova.

The only interesting mammalian animal which I saw at Villa Nova was a monkey of a species new to me : it was not, however, a native of the district, having been brought: by a trader from the river Nadeira, a fen miles above Borba. It was a howler, proba bly the Mycetes stramineus of Geoffroy St Hilaire. The howlers are the only kinds $\mathrm{O}_{2}$. monkey which the natives have uot succeed. ed in taming. They are often cauglit, but: they do not survive captivity many weeks. The one of which I am speaking was not: quite full grown. It measured sixteen inches. in length, exclusive of the tail; the whole. body was covered with rather long and shin. ing dingy-white hair, the whiskers and beard: only being of a tawny hue. It was kept in a. house, together with a Coaita und a Caiarára. mouliey (Cebus albifrons). Both these lively. 
meminers of the monkey order seemed rather (1) co:irt attention, but the Mycetes slunk uway when any one approached it. When it fiist arrived, it occusionally made a gruff subdieil howling noise early in the morning. The dere vrilume of sound in the voice of the howliner raiskeys, as is well known, is prolucel by a drum-shaped expansion of the lary'nx. It was curious to wateh the animal while renting its hullow cavernous roar, and observe how small was the muscular exertion (mpl,yel. When howlers are seen in the folest, there are generally three or four of them mounted on the topmost branches of a tree. It does not appear that their harrowing roar is emitted from sudden alarm; at least, it was not so in captive individuals. It is probable, however, that the noise serves to intimidate their enemies. I did not meet with the Mycetes stramineus in any other part of the Amazons region; in the neighborhood of Pará a reddish-colored species prevails (M. Belzebutlı) ; in the narrow chan nels near Breves I shot a large, entirely black kind ; anotler yellow-handed species, accolding (1) the report, of the natives, inhabits the island of Macajo, which is probably the $M$. flivimanus of Kuhl: some distance up the Taprijos the only howler found is a brownish black species; and on the Upper Amazons the sole species scen was the Mycetes ursiuus, whose fur is of a shining yellowish-red color.

In the dry forests of Villa Nova I saw a rattlesnake for the first time. I was return. ing home one day through a narrow alley, when I heard a pattering noise close to me. Hard hy was a talm palm-tree, whose head wus hcavily weighted with parusitic plauts, and I thought the noise was a warning that it was about to fall. The wind lulli $d$ for a few moments, and then there was no doubt that the noise proceeded from the ground. On turning my head in that direction, a sud. -den plunge startled me, and a heavy gliding motion betrayed a large serpent making off almost from beneath my feet. The ground is ulways so incumbered with rotting leaves ond branches that one only discovers snakes when they are in the act of moving awuy. The r esidents of Villa Nova would not believe that I had seen a rattlesnake in their neighboshood ; in fact, it is not known to occur in the furests at all, its place being the open cimpos, where, near Santarem, I killed several. On my recond visit to Villa Nova I saw anuther. I had then a favorite little dog, nilmed Diamante, who used to accompany me in siy lanubles. One day he rushed into the thicket, and made $u$ dead set at a large snalie, whose head I saw raised abuve the herbage. The foolish little brute approached quite cluse, and then the serpent reared its tail slightly in a horizontal position and shook its terrible rattle. it was many minutes before I could get the dog away and this incident, as well as the one already related, shows how slow the reptile is tu make the fatal spring.

I was much annoyed, and at the same time amused, with the Urubú vultures. The Por- tuguese call them corvos or crowe - In cotor and general appearance they somewhat resemble rooks, but they are much larger, and have naked, black, wrinkled skin about their face and throat. They assemble in great numbers in the villages about the end of the wet season, und are then ravenons with bun. ger. My cook could not leave the upen kitchen at the back of the house for a moment, while the dinner was cooking, on ac count of their thievish propensities. Some of them were always lvilering about, watch ing their opporlunity, and the instant the kitcher was left unguarled the bold marauders marched in and lifted the licls of the saucepuns with their heaks to rob them of their contents. The boys of the village lie in wait and shoot them with bow and arrow; and vultures have consequently acquired such a dread of these weapons that they may be often kept uff by hanging a bow from the rafters of the kitchen. As the dry season advances the hosts of Urubús follow the fishermen to the lakes, where they gorge themselves with the offal of the fisheries. Toward February they return to the villages, and wre then not nearly so ravenums as before their summer trips.

The insects of Villa Nova are, to a grent ixtent, the sume as those of Santarem and the Tapajos. A few species o: all orders, how. ever, ure found here, which occurred no. where else on the Amazons, besides several others which are propesly considered local varieties or races of others found at Pará, on the northern shore of the Amazons, or in other parts of tropical America. The Hymenoptera were especially numerous, as they always are in districts which possess a sandy soil ; but the many interesting facts which 1 gleaned re!ative to their habits will be more conveniently introduced when I treat. of the same or similar species found in the lccalities above named. In the liroad alleys of the forest several species of Morpho were common. One of these is a sister form to the Morpho Hecuba, which I have mentioned as occurring at Obydos. 'The Villa Nova kind differs from Hecuba sutficiently to be considered a distinct species, aud has been described under the name of M. Cisseis; but it is clearly only a local variety of it, the range of the two being limited by the burrier of the broad Amazons. It is a grand sight to see these colossal butterflies by twos and threes floating at a great height in the still air of a tropical morning. They flap their wings only at long inter-als, for I have noticed them to sail u very considerable distance without a stroke. Their wing-muscles, and the thorax to which they are attached, are very feeble in comfr.iuson with the wile extent and wi ight of the wings; but the large expanse of these nembers doubtless assists the insects in maintaining their aerria' course. Morphos are among the most conspicuous of the insect denizens of tropical American forests, and the broad glades of the Villa Nova tvrods se mmed especially suited to them, for I noticed $b$ re s'x species. The largest speci- 
mens of Morpho Cisseis measure seven inches and a half in expanse. Another smaller kind, which I could not capture, was of a pale silvery-blue color, and the polished surface of its wings flashed like a silver specuJum, as the insect flapped its wings at a great elevation in the sunligbt.

To resume our voyage. We left Villa Nova on the 4 th of December. A light wind on the 5th carried us across to the opposite shore and past the mouth of the Paranámirim do arco, or the little river of the bow, so called on account of its being a short arm of the main river, of a curved shape, rejoining the Amazons a little below Villa Nova. On the 6th, after passing a large island in mid-river, we arrived ut a place where a line of perpendicular clay cliffs, called the Barreiros de Cararaucú, diverts slightly the course of the main stream, as at Obydos. A little below these clitis were a few settlers' houses: here Penua remained ten days to trade, a delay which I turned to good account in augmenting very considerably my collections.

At the first house a festival was going forward. We anchured at some distance from the shore, on account of the water being shoaly, and early in the morning three canoes put off, laden with salt fish, oil of manatee, fowls, and bananas, wares which the owners wished to exchange for different articles required for the festa. Soon after I went ushore. The head man was a tall, wellmade civilized 'Tapuyo, named Marcellino, who, with his wife, a thin, active, wiry old aquaw, did the honors of their house, I thought, admirably. The company consisted of fifty oc sixty Indians and mamelucos; some of them knew Portuguese, but the Tupí language was the nnly one used among themselves. The festival was in honur of our Lady of Conception; and when the people learned that Penna had on board an image of the saint handsomer than their own, they put off in their canoes to borrow it ; Marcellino taking charge of the dull, covering it carefully with a neatly-bordered white towel. On landing with the image, a procession was formed from the port to the house, and salutes fired from a couple of lazarino guns, the saint being afterward carefully deposited in the family oratorlo. After a litany and hymu were sung in the evening, all assem. bled to supper around a large mat spread on a smooth terrace-like space in front of the house. The meal consisterl of a large boiled Pirarecú, which had heeu harpooned for the purpose in the morning, stewed and roasted turtle, piles of inaudioca-meal, and bananas. The old lady, with two young girls, showed the greatest activity in waiting on the guests, Marcellino standing gravely by, observing what was wanted, and giving the necessary orders to his wife. When all was done, hard drinking began, and soon after there was a dance, to whieh Penna and I were invited. The liquor served was chiefly a spirit distilled by the people themselves from mandioca cakes. The dances were all of the same class, namely, different varieties of the "landum," an erotic dance similar to the fandangn, originally learned from the Portu. guese. The inusic was supplied by a couple of wire-stringed guitars, played alternately by the young men. All passed off very quietly, considering the amount of strong liquor drunk, and the ball was kept up until sunrise the next morning.

We visited all the houses one after the other. One of them was sicuated in a charm. ing spot, with a broad sandy beach before it, at the entrance to the Paruná-mirím do Mucámbo, a channel leading to an interior lake, peopied by savages of the Múra tribe. This seemerl to be the abode of an industrions family, but all the men were absent, salting Pirarecú on the lakes. The house, like its neighbors, was simply a framework of poles thatched with palm-leaves, the walls roughly latticed and plastered with mud; but it was larger, and much cleaner inside than the others. It was full of women and children, who were busy all day with their various empioyments : some weaving hammocks in a large clumsy frame, which held the warp. while the shuttle was passed by the hand slowly across the six feet breadth of web: others spinning cotton, and others again scraping, pressing, and roasting mandioca. The family had cleared and cultivated a large piece of ground; the soil was of extraordinary richuess, the perpendicular banks of the river, near the house, reveuling a depth of many feet of crumbling vegetablu mould. There was a large plantation of tobacco, besides the usual patches of Indian corn, sugar-cane, and mandioca; and a grove of cutton, cacao, cuffee and fruit trees surrounded the house. We passed two. nights at anchor in shoaly water off the beach. The weather was most beautiful, and scores of dolphins rolled and snorted about the canoe all night.

We crossed the river at this point, and entered a narrow channel which penetrates the interior of the island of Tupinambarána, and leads to a chuin of lakes called the Lagos de Cararaucú. A furious current swept along the coast, eating into the crumbling earthy banks, and strewing the river with dábris of the forest. The mouth of the channel lies about twenty-five miles from Villa Nova; the entrance is only about forty yurds broad, but it expands, a short distance inland, into a large sheet of water. We suffered ter ${ }^{* i b l y}$ from insect pests during the twenty-four hours we remained liere. At night it $p^{*}$ is quite impossible to sleep for mosquitotes; they fell upon us by myriuds, and without much piping came straiglit at our faces as. thick as raindrops in a slower. The men crowded into the cabins, and then tried to expel the pests by the smoke from burned. rags, but it was of little avail, although we. were half suffocated luring the operation. In the daytime the Motúca, a much larger and more formidable fly than the mosquito, Insisted upon lerying his tax of block. We liad been tormepted by it for many days past. . 
A) this p ace seemed to be its metropolss. The species has been described by Perty, the authur of the Entomolugical portion of Spix and Martius' travels, under the name of Harlrus lepidotus. It is a member of the Tabanidx family, and indeed is closely related to the Hæmatopota pluvialis, a brown ffy which haunts the borders of wouds in - summer time in England. The Motáca is of a brunzed-black color; its probeseis is forwed of a bundle of horny lancets, which are shorter and broader than is usually the case in the family to which it belongs. Its puncture does not produce much pain, but it makes such a large gash in the flesh that the blood trickles forth in little streams. Many scores of them were flying about the canoe all day, and sometimes eight or ten would settle on onc's ankles at the same time. It is sluggish in its motions, and may be easily killed with the fingers when it settles. Penna went forward in the montaria to the Pirarecú fishing stations, on a lake lying further inland; but he did not succeed in reaching them on account of the length and intricacy (f the channels ; so after wasting a day, dising which, however, I had a protitable ramble in the furest, we again crossed the river, and on the 16 th continued our voyage alnng the northern shore.

The clay clitfs of Cararaucu are several miles in length. The hard pink-and-redcolored beds are here extremely thick, and in some places present a compact stony texture. The total height of the cliff is from thirty to :sixty feet above the mean level of the river, and the clay rests on strata of the same coarse iron-cemented conglomerate which has - already been so often mentioned. Large blocks of this latter bave been detaclsed and rolled by the force of currents up parts of the riff, where they are seen resting on terraces of the clay. On the top of all lies a bed of sand and regetable mould, which supports a lofty forest, growing up to the very brink of the precipice. After passing ther $\theta$ barreiros we continued our way along a low uniuhabited coast, clothed, wherever it was elevated above high-water murk, with the usual vividly-colored forests of the higher Ygapó lands, to which the broad and regular fronds of the Murumura palm, here ex. tremely abundant, served as a great decoration. Wherever the land was lower than the flood height of the Amazons, Cecropia trees prevailed, sometimes scattered over meadows of tall b. vid leaved grasses, which surrounded shelluw pools swarming with water-fowl. Alligat $)$ we we common on most parts of the coust ; in scine places we saw also small herds of Capybaras (a large Rodent animal, like a colussal Guinea-pig) among the rank herbage on muddy banks, and now and then flocks of the graceful squirrel monkey (Chrysothrix sciureus), and the vivacious Caiarára (Cebus albifrons) were seen taking flying leaps frcm tree to tree. On the $22 \mathrm{~d}$ W'e passed the mouth of the most easterly of the numerous channels which lead to the large inatterior lake of Saracá, aud on the 23d threaded a series of passages between islands, where we again saw human habitations, ninety miles distant from the last house at Cararaucú. On the 24th we arrived at Serpa.

Serpa is a small village, consisting of about eighty houses, built on a bank elevated twenty-five feet above the level of the river. The beds of Tabatinga clay, which are here intermingled with scoria-looking conglomerate, are in some parts of the declivity prettily variegated in color; the name of the town iu the Tupí language, Ita-coatiára, takes its origin from this circumstance, signifying striped or painted rock. It is an old settlement, and was once the seat of the district government, which had authority over the Barra of the Rio Negro. It was in 1849 a wretchedlooking village, but it has since revived, on account of having been chosen by the steamboat Company of the Amazons as a station for steam saw-mills and tile manufactories. We arrived on Christmas-eve, when the village presented an animated appearance from the number of people congregated for the holidays. The port was full of canoes, large and small-from the montaria, with its arched awning of woven lianas and aranta. leaves, to the two-masted cuberta of the peddling trader, who had resorted to the place in the hope of trafficking with settlers coming from remote sitios to attend the festival. We anchored close to an igarité, whose owner was au old Jurí Indian, disfigured by a large black tattooed patch in the middle of his face, and by his hair being close cropped, except a fringe in front of the head. In the afternoon we went ashore. The population seemed to consist chiefly of semi-civilized In. dians, living as usual in half-finished mud hovels. The streets were irregulariy laid out, and overrun with weeds and bushes swarming with " mocuim," a very minute scarlet acarus, which sweeps off to one's cluthes in passing, and attaching itself in great numbers to the skin causes a most disagreeable itching. The few whites and better class of mameluco residents live in more substantial dwellings, whitewashed and tiled. All, both men and women, seemed to me much more cordial, and at the same time more brusque in their manners than any Brazilians I had yet met with. One of them, Captain Manoel Joaquim, I knew for a long time afterward; a lively, intelligent, and thoroughly good-hearted man, who had quite a reputation throughout the interior of the country for generosity, and for being $u$ firm friend of foreign residents and stray travellers. Some of these excellent people were men of substance, being owners of trading vessels, slaves, and extensive plantations of cacao and tobacco.

We stayed at Serpa five days. Some of the ceremonies ohserved at Christmas were interesting, inasmuch as they were the same, with little modification, as those taught by the Jesuit missionaries more than a century ago, to the aboriginal tribes whom they had induced to settle on this spot. In the morning all the women and girls, dressed in white 
gauze chemises and showy calico print pettlcoats, went in procession to church, first yoing the round of the town to take up the ditterent " mordomos," or stewards, whose oftice is to assist the Juiz of the festa. These : stewards carried each a long white reed, decorated with colored ribbons ; several children also accompanied, grotesquely decked with finery. Three old squaws went in front, holding the "sairé," a larye semicircular frame, clothed with cotton and studded with ornaments, bits of looking-glass, and so forth. This they danced up and down, singing all the time a monotonous whining hymn in the 'Tupí language, and at frequent intervals turning ruund to face the followers, who then all stupped for a few moments. I was told that this sairé was a device adopted by the Jesuits to attract the savages to church, for these everywhere followed the mirrors, in which they saw as it were magically reflected their own persons. In the evening good-humored revelry prevailed on all sides. 'The negroes, who had a saint of their own color-St. Benedito-had their holiday apart from the rest, and spent the whole night singing and dancing, to the music of a long druin ( (gambá) and the caracashí. The drum was - a hollow log, having out end covered with skin, and was played by the performer sitting - astride upon it and drumming with his knuckles. The caracasha is a notched bamboo tube, which produces a harsh rattling noise by passing a hard stick over the notches. Nothing could exceed in dreary monotony this music and the singing and - dancing, which were kept up with unflagging vigor all night long. The Indians did not get up a dance ; for the whites and mam- elucos had monopolized all the pretty colored girls for their own ball, and the older squaws preferred looking on to taking a part themselves. Some of their hushands joined the negrues, and got drunk very quickly. It was amusing to n'tice how voluble the usually tacituru red-skins became under the influence of liquor. The negroes and Indians excused their own intemperance by saying the whites were getting drunk at the other end of the town, which was quite true.

We left Serpa on the 29th of December, in company of an old plunter named Senhor Joaō (John) Trinidade; at wlose sitio, situated oppusite the mouth of the Madeira, Penna intended to spend a few days. Our course on the 29th and 30 th lay through nar. row channels between islands. On the 31st we passerl the last of these, and then beheld to the siruth a sca-like expanse of water, iwhere the Madeira, the greatest tributary of the Am:zons, after 2000 miles of course, blends its waters with those of the king of rivors. I was hardly prepared for a junction of waters on so vast a scale as this, now nearly 900 miles from the sea. While travel. ling week after week along the somewhut monotonous stream, often hemmed in between islands, and becoming thoroughly familiar with it, my sense of the magnitude of this vast wuter system had become gradu- ally deudened ; but this noble sight renewed the first feelings of wonder. One is inclined, in such places as these, to think the Paraenses do not exaggerate much when they call the Amazons the Mediterranean of Suuth Ameri. ca. Beyond the mouth of the Madeira, the Amazons sweeps down in a majestic reach, to all appearance not a whit less in breadtb before, than after, this enurmous addition to its waters. The Madeira does not ebb and flow simultaneously with the Amazons; if rises and sinks about two months earlier, so that it was now fuller than the main river. Its current therefore poured forth freely from its mouth, carrying with it a long line of floatiug trees and patches of grass, which had been toin from its crumbly banks in the lower part of its course. The current, how. ever, did not reach the middls of the main stream, but swept along nearer to the south. ern shore.

A few items of information which I gleaned relative to this river may find a place here. The Madeira is navigable for about 480 miles from its mouth; a series of cataracts und rapids then commences, which extends, with some intervals of quiet water, about 160 miles, beyond which is another long stretch of navigable stream. Canoes sometimes descend from Villa Bella, in the interior province of Matto Grosso, but not so frequently as fcrmerly, and I could hear of very few persons who had attempted of late years to ascend the river to that point. It was explored by the Portuguese in the early part of the eighteenth century ; the chief and now the only town on is banks, Borba, 150 miles from its mouth, being founded in 1756. Up to the year 1853, the lower part of the river, as far as about 100 miles beyond Borba, was regularly visited by traders from Villa Nova, Serpa, and Barra, to collect sarsaparilla, copaiba balsam, turtle oil, and to Irade with the Indians, with whom their relations were generally ou a friendly footing. In that year many india-rubber collectors resorted to this region, stimulated by the high price $(2 s, 6 d$. per pound) which the article was at that time fetching at Pará ; and then the Aráras, a fierce and intractable trihe of Indians, began to be troublesome. They attacked several canoes and massacred every one on board, the Indian crews as well as the white traders. Theil plan was to lurk in arnbush near the sandy beaches, where canoes stop for the night. and then fall upon the people while asleep. Sometimes they came under pretence of wishing to trade, and then as soon as they could get the trader at a disadvantage shot him and his (rew from belind trees. Their arms were clubs, bows, and Taquára arrows, the latter a tormiduble weapon tipped with a piece of flinty hamboo shaped like a spear. head ; they could propel it with such force as to pierce a man completely through the body. The whites of Borba made reprisals, induc. ing the warlike Mundurucús, who had an old feud with the Aráras, to assist them. This state of thiugs lasted two or three years, and made a juurney up the Madeira a risky un. 


\section{- THE NATURALIST ON T HE RIVER AMAZONS.}

dertuklng, as the savages attacked all comers. Besides the Aráras and the Mundurucús, the istter a tribe friendly to the whites, attached to agriculture, und inhabiting the interior of the country from the Madeira to beyond the Tapajos, two other tribes of Indians now inhabit the lower Madeira, namely, the Parentintins and the Muras. Of the former I did not hear : nuch ; the Muras lead a lazy quiet life on the banks of the labyrinths of lakes and channels which intersect the low country on buth sides of the river below Burba. The Aráras are one of those tribes which do not plant mandioca, and indeed have no settled habitations. They are very similar in stature and other physical features to the Muudurucús, although differing from them so widely in habits and social condition. They paint their chins red with Urucú (auatto), and have usually a black tattooed streak on each side of the face, running from the corner of the mouth to the temple. They have not yet learned the use of firearms, have no canoes, and spend their lives roaming over the interior of the country, living on game and wild fruits. When they wish to cross a river they make a temporary canoe with the thick bark of trees, which they secure in the required shape of a boat by means of lianas. I heard it stated by a trader of Santarem, who narrowly escuped being butchered by them in 1854 , lluat the Aráras numbered two thousand fighting men. The number I think must be exaggerated, as it generally is with regard to Brazilian tribes. When the Indians show a hostile disposition to the whites, I believe it is most frequently owing to some provocation they have received at their hands; for the first impulse of the Braziliau red-man is to respect Euro. peans ; they have a strong dislike to be forced into their service, but if strungers visit them with a friendly intention they are well treated. It is related, however, that the Indians of the Madeira were hostile to the Portuguese frum the first; it was then the tuibes of Muras and Torazes who attacked travellers. In 1855 I met with an American, an odd character, named Kemp, who had lived for many years among the Indians on the Madeira, near the ubandoned settlement of Crato. He tull me his neighbors were a kindly-disposed and cheerful pecple, and that the onslaught of the Aráras was provoked by a trader from Barra, who wantonly tired into a fumily of them, killing the parents, and carrying off their children to be employed as domestic servants.

We remained nine days at the sitio of Senhor John Trinidade. It is situated on a tract of high $Y$ gapó land, which is suised, however, only a few inches alove high-water mark. This skirts the northein shoie for a long distance ; the soil consisting of alluvium and $t$ ich vegetable mould, and exhibiting the most exuberant 1ertility. Such districts are the first to be settled on in this comntry, and the whole coast for many miles was dottin with pleasant-looking sitios like that of vus friend. The establishment was a large one the house and out-buildings covering a large space of ground. The industrious propilietor seemed to be jack-of-all-trades; he was planter, trader, fisherman, and canoe-builder, and a large igarité was now on the stocks. under a large shed. There was great pleasure in contemplating this prosperous faim, from its being worked almost entirely by freelabor ; in fact, by one family und its dependants. Jolin Trinidade had only one female slave; his other workpeuple were a. brother and sister-in-law,"two godsons, a free negro, one or two Indians, and a family of Muras. Butl he and his wife were maneJucos; the negro children called them always father and mother. The urder, abundance, and comfort ahout the place showed what industry and good management could effect in this country without slave-labor. But the surplus produce of such small plantations is very trifling. All we saw had been done since the disorders of 1835-6, during which John Trinidade was a great sufferer; he was obliged to fly, and the Mura Indians destroyed his house and plantations. There was a large, well. weeded grove of cacao along itue banks of the river, comprising about 8000 trees, and farther inland considerable plantations of tobacco, mandioca, Indian corn, fields of rice, melons, and water-melons. Near the house was a kitchen-garden, in which grew cabbages and onions introduced from Europe, besides a wonderful variety of tropical vegetables. It inust not be supposed that these plantations and gardens were incloser or neatly kept ; such is never the case in this country, wliere labor is so scarce ; but it was an unusual thing to see vegetables grown at all, and the ground tolerably well weeded. The space around the house was plentifully planted with fruit-trees, some, belonging to the Anonaceous order, yielding delicicus fruits large as a child's head, and full of cus. tardy pulp which it is necessary to eat with a spoon; besides oranges, lemons, guavas, alligator pears, Abíus (Achras cainito), Genipapas, and bananas. In the shade of these, coffee-trees grew in great luxuriance. The table was always well supplied with fish. which the Mura, who was attached to the household as fisherman, caught every morning a few liundred yards from the port. The chief kinds were the Surubim, Pira-peëua, and Piranutába, three species of Silurilie, belonging to the genus Pimelodis. To these we used a sauce in the form of a jelluw paste, quite new to me, called Arubé, whick. is made of the poisunous juice of the mandioca root, boiled down before the starch or tapioca is precipitated, und seasoned with capsicum peppers. It is $\mathrm{kept}$ in stons bottles several weeks before using, and is a most appetizing relish to fish. Tucupi, unother sauco male aisa from mandioca juice, is mucb more cisumon in the interior of the countr, than Arubé. This is made by boiling or heatiug the pure liquid, after the tapioca has ber" " par at daily for several days in suc-

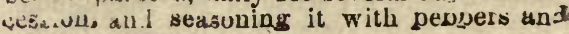


small folies; when old it has the taste of essence of anchovies. It is generally made as a liquid, but the Jurí and Miranlia tribes on the Japura, make it up in the form of a black paste, by a mode of preparation I could not learn : it is then called Tucupípixúna, or black 'Tucupi. I have seen the Indians on the Tapajos, where fish is scarce, season Tucupi with Saübu ants. It is there used chiefly as a sauce to 'Tacacá, another preparation from mandioca, consisting of the statch beaten up in boiling water.

I thoroughly enjoyed the nine days we spent at this place. Our host and lostess took an interest in my pursuit; one of the best chambers in the house was given up to me, and the young men took me long rambles in the neighboring forests. I saw very little hard work yoing forward. Every one rose with the dawn, and went down to the river to bathe; then came the never-failing cup of rich and strong coffee, after which all proceeded to their avocations. At this time nothing was being done at the plantations; the cacuo and tobacco crops were not ripe weeding time was over, and the only work on foot was the preparation of a little furinha by the women. The men dawdled about : went shooting and fishing, or did trifling jobs about the bouse. The only laborious work doue during the year in these establishments is the felling of timber for new clearings; this happens at the beginning of the dry season, namely, from July to September. What ever empluyment the peuple were engaged in, they did not intermit it during the hot hours of the day. Those whu went into the woods took their dinners with them-r small bag of farinha and a slice of salt fish. About sunset all returned to the house; they then had their frugal suppers, and toward eight o'clock, after coming to ask a blessing of the patriarchal head of the household, went off to their hammocks to sleep.

John Trinidade was famous for his tobacco and cigarettes, as he took great pains in preparing the Tauari, or envelope, which is formed of the inner bark of a tree, separated into thin papery layers. Many trees yield it, among them the Courataria Guianensis and the Sapucaya nut-tree, both belunging to the same natural order. The bark is cut in long strips, of a breadth suitable for folding the tobacco; the inner portion is then separated, boiled, hammered with a wooden mallet, and exposed to the air for a few hourz. Some kinds have a reddish color and an astringent taste, but the sort prepared by our host was of a beautiful satiny-white hue, and perfectly tasteless. He obtained sixty, eighty, and sometimes a hundred layers from the same strip of bark. The best tobacen in Brazil is grown in the neighborhood of $\mathrm{B}$ orba, on the Madeira, where the soil is a rich black lesm; but tobacco of very good quality was grown by John Triuidade and his neiglıbors al ung this coast, on similar soil. It is mar? "1p? into slender rolls, an inch and a hul: in diameter and six feet in length, tapering : each end. When the leaves are suthered surt partially dried, layers of them, after the mid ribs are plucked out, are placed ou a mat and rolled up into the required shape. This is done by the women and children, who also manage the planting, weeding, and gathering of the tobacco. The process of tightening the rolls is a long and heavy task, and can be done only by men. The cords used for this purpose are of very great strength. They are made of the inner bark of a peculiar light-wooded and slender tree, called Uais síma, which yields, when beaten out, a great quantity of most beutiful silky fibre, many feet in length. I think this might be turned to some use by English manuiacturers, if they could obtain it in large quantity. The tree is abundant on light soils on the southern side of the Lower Amazons, and grows very rapidly. When the rolls are sufficiently well pressed, they are bound round with narrow thougs of remarkable toughness, cut from the bark of the climbing Jacitára palmtree (Desmoncus macrancathus), and are then ready for sale or use.

It was very pleasant to roam in our host's cacanal. The ground was clear of underwood, the trees were about thirty feet in height, and formed, a dense shade. Two species of munkey frequented the trees, and, I was tuld, committed great depredations when the fruit was ripe. One of these, the macaco prego (Cebus cirrhifer ?), is a must impudent thief ; it destroys more than it eats, by its random, hasty way of plucking and breaking the fruits, and when about to return to the forest carries away all it can in its hands or under its arms. The other species, the pretty little Chrysothrix sciureus, contents itself with devouring what it can on the spot. A variety of beautiful iusects basked on the foliage, where stray gleams of sunlight glanced through the canopy of broad soft-green leaves, and numbers of an elegaut long-legged tiger-beetle (Odontucheila egregia) ran and flew about over the herbuge.

We left this place on the 8 th of January, and on the afternoon of the 9 th arrived at Maturí, a miserable little settlement of Múru Indians. Here we again anchored and wen. ashore. The place consisted of about twenty slightly-built mud hovels, and had a most forlorn appearance, notwithstanding the lux. uriant forest in its rear. A borde of these Indians settled here many years ago, on the site of an abanduned missionary station, and the Givvernment had lately placed a resident director over them, with the intention of bringing the hitherto intractable savages un. der authority. This, however, seemed to promise no other result than that cf driving them to their old solitary haunts, on the hanks of the interior waters, for many fam. ilies had already withdrawn themselves. The absence of the usual cultivated trees und plants gave the place a naked und povertystricken aspect. I entered one of the hovels, where several women were employed cooking a meal. Portions of a large fish were ronsting over a file made in the midd!e of the low ihanlier, and the entrails were scattered 
about the floor, on which the women winn their children were squatted. These had a timid, distrnstful expression of countenance, und their bodies were begrimed with black mud, which is smeared over the skin as a protection agaiust mosquitoes. The children were naked, the women wore petticoats of coarse cluth, ragged round the edges, and stained in blotches with murixí. a dye made from the bark of a tree. One of them wore a necklace of monkey's teeth. There were scarcely any household utensils; the place was bare with the exception of two dirty grass hammocks hung in the corners. I missed the usual mandioca sheds behind the house, with their surrounding cotton, cacao, coffee, and lemon trees. Two or three young men of the tribe were lounging about the low open doorway. They were stoutly-built fellows, but less well-propurtioned than the semi-civilized Indians of the Lower Amazons generally are. Their breadth of chest was remarkable, and their arms were wonderfully thick and muscular. The legs appeared short in proportion to the trunk; the expression of their cuuntenances was unmistakably more sullen and brutal, and the skin of a darker hue, shan is common in the Brazilian red man. Before we left the hut an old couple came in; the husband carrying his paddle, bow, arrows, and harpoun, the woman hent beneath the weight of a large basket filled with palm fiuits. The man was of low stature and had a wild appearance frum the long coarse hair which hung over his forehead. Both his lips were pierced with holes, as is usual with the older Múras seen on the river. They used formerly to wear tusks of the wild hog in these boles whenever they went out to encounter strangers or their enemies in war. The gloomy savagery, filth, and poverty of the people in this place made me feel quite melancholy, and I was glad to return to the canoe. They offered us no civilities; they did not even pass the ordinury salutes, which all the semicivilized and many savage Indians proffer on a first meeting. The men persecuted Penna for casliaça, which they scemed to consider the only good thing the white man brings with him. As they had nothing whatever to give in exchange, Penna declined to supply them. They fullowed us as we descended to the port, becuming very troublesome when about a dozen had collected together. They brought their empty bottles wita them, and promised tish and turtle, if we would only trust them first with the coreted aguardente, or vau-im, as they called 1t. Penua was inexorable: he ordered the crew 10 weigh anchor, and the disappointed savages remained hooting ufter us with all their might, from the top of the bank, as we glided away.

After leaving Matari we continued our voyage along the northern shore. The banks of the river were of moderate elevaticn during several days' journey; the terla firms lying tar in the interior, and the coast being either low land, or masked with islands of alluvial formation. On the 14th we nassed the upper mouth of the Parana-mirim de Eva, an arm of the river of small breadth, formed by is straggling island some ten miles in length, lying parallel to the northern bank. On passing the western end of this the main. land again appeared, a rather high rocky coast, cluthed with a magnificent forest of rounded outline which continues hence for twenty miles to the muuch of the Ric Negro, and forms the eastern shore of that river. Many houses of settlers, built at a considerable elevation on the wooded heights, now enlivened the river banks. One of the first. objects which here greeted us was a beauliful bird we had not hitherto met with, namely, the scarlet and black tanager (Ramphocœlus nigrogularis), flocks of which were seen sporting about the trees on the edge of the water, their flame-colored liveries lighting up the masses of dark-green foliage.

The weather, from the 14 th to the $18 \mathrm{th}$, Wиs wretched; it rained sometimes for twelve hours in succession, not heavily, but in a steady drizzle, such as we are familiar with in our English climate. We lauded at several places on the coast, Penna to trade as usual, and I to ramble in the furest in search of birds and insects. In one spot the wooded slope inclosed a very picturesque scene : a brook, flowing through a ravine in the high bank, fell in many little cascades to the broad river beneath, its margins decked out. with an infinite variely of beautiful plants. Wild bananas arched over the water-course, and the trunks of the trees in its vicinity were clothed with ferns, large-leaved species belonging to the genus Lygodium, which, like Osmunda, have their spore-cases collected together on contructed !eaves. On the 18th we arrived at a large fazenda (plantation and cattle farm), called Jutuarána. A rocky point here projects into the stream, and as we found it impossible to stem the strong current which whirled round it, we crossed over to the southern shore. Canoes in approaching the Rio Negro generally prefer the southern side on account of the slackness of the current near the banks. Our progress, however, was most tediously sluw, for the regular east wind had now entirely ceused, and the vento de cima or wind from up river, having taken its place, blew daily for a few hours dead against us. The weather was. oppressively ciose, and every afternoon a squall arose, which, however, as it came from the right quarter and blew fur an hour or two, was very welcome. We marle acquaintance on this cuast with a new insect. pest, the Piúm, a minute fly, two thirds of a. line in length, which here commences its reign, and continues henceforward as a terrible scourge along the upper river, or Solimoens, to the end of the navigation on the Amazons. It comes forth only by day, relieving the mosquitu at sunrise, with the greatest punctuality, and occurs ouly near the muddy shores of the stream, not one ever being found in the shade of the forest. In places where it is abundant, it accompanies canves in such dense swarnas as to resemble. 
wil. vavus of smoke. It made its appearance in this way the first day after we crossed the river. Before I was aware of the presence of flies I felt a slight itching on my neck, wrist, and ankles, and on looking for the cause saw a number of tiny objects having a disgusting resemblance to lice, adhering to the skin. This was my introduction to the much-talked-of Piúm. On close examination they are seen to be minute twowinged insects, with dark-colored body and pale legs and wings, the latter closed lengthwise over the back. They alight imperceptibly, and squatting close, fall at once to work, stretching forward their long front legs, which are in constant motion and seem to act as feelers, and then applying their short, broad snouts to the skin. Their abdomens soon become distended and red with blood, and then, their thirst sutisfied, they slowly more off, sometimes so stupefied with their potations that they can scarcely fly. No pain is felt while they are at work, but they each leave a small circular raised spot on the skin and a disagreeable irritation. The latter may be avoided in great measure by pressing out the bluod which remuins in the spot ; but this is a troublesome task, when one has several hundred punctures in the course of a day. I touk the trouble to dissect spectmeus to ascertain the way in which the little pests operate. The muuth consists of a pair of thick fleshy lips, and two triangular horny lancets, answering to the upper lip and tongue of other insects. This is applied glusely to the skin, a puncture is made with he lancets, and the blood then sucked through between these into the œsophagus, the circular spot which results coinciding with the shape of the lips. In the course of a few days the red spots dry up, and the skin in time becomes blackened with the endless number of discolored punctures that are crowded together. The irritation they produce is more acutely felt by some persons than others. I once travelled with a middleaged Portıguese, who was laid up for three weeks from the attacks of Piúm, his legs being swollen to an enormous size, and the punctures aggravated into spreading sores.

A brisk wind from the east sprang up early in the morning of the $22 \mathrm{~d}$; we then hoisted all sail, and made for the mouth of the Rio Negro. This noble stream at its junction with the Amazons seems, from its position, to be a direct continuation of the main river, while the Solimoens, which joins at an angle and is somewhat narrower than its tributary, appears to be a branch instead of the main trunk of the vast water-system. One sees therefore at once how the early explorers came to give a separate name to this upper part of the Amazons. The Brazilians have lately taken to applying the convenient term Alto Amazonas (High or Upper Amuzons) to the Soliomeus, and it is probable that this will gradually prevail over the old name. the Rio Negro broadens considerably from its mouth upward, and presents the appenrance of a great lake; its black-dyed waterş having no current and seeming to be dammed up by the impetuous flow of the yellow, turbid Solimoens, which here belches forth a continuous line of uprooted trees and patches of grass, and forms a striking cuntrast with its tributary. In crossing we passed the line, a little more thun half way over, where the waters of the twu rivers meet and are sharply demarcated from each other. On reaching the opposite shore we found a remarkable change. All our insect pests had disappeared, as if by magic, even from the hold of the canoe : the turmoil of an agitated, swiftly flowing river, and its turn, perpendicular, earthy banks, had given place to tranquil water and a coast indented with snug little bays, fringed with sloping sandy beaches. The low shore and vivid light green endlessly-varied foliage, which prevailed on the south side of the Amazons, were exchanged for a hilly country, clothed with a sombre, rounded, und monutonous forest. Our tedious voyage now approached its termination; a light wind carried us gently along the coast to the city of Barra, which lies about seven or eight miles within the mouth of the river. We stopped fur an hour in a clean little bay, to bathe and dress, before showing ourselves again among civilized people. The bottom was visible at a depth of six feet, the white sand taking a brownish tinge from the stained but clear water. In the evening I went ashure, and was kindly received by Senhor Henriques Antony, a warm-hearted Italian, established here in a high position as merchant, who was the never failing friend of stray travellers. He placed a couple of roous at my disposal, and in a few hours I was comfortably settled in my new quarters, sixty-four days after leaving Obydos.

I found at Barra my companion, Mr. Wallace, who, siuce our joint Tocantins expcdition, had been expluring, paitly with his brother, lately arrived from Enyland, the north - eastern coast of Marajó, the river Capim (a branch of the Guamá, near Pasá), Monte Alegre, and Santarem. He had passed us by night below Serpa, on his way to Barra, and so had arrived about three weeks before me. Besides ourselves there were half a dozen other foreigners here congregated - Englishmen, Germans, and Ameı. cans-one of them a natural-history collect. or, the rest traders on the rivers. In the pleasant society of these, and of the fumily of Seuhur Henriques, we passed a delightful time ; the miseries of our long river voyages were suon forgotten, and in two or thice we ks we began to talk of further explora. tions. Meantime we had almost daily rambles in the neighboring forest. The whole surface of the land, down to the water's edge, is covered by the uniform dark green rolling forest, the caá-apoam (convex woods) of the Indians, characteristic of the Rio Negro. This clothes also the extensive artus of low land, which are flooded by the iver in the rainy seasun. The ulive-brown 
tinge of the water seems to be derived from the saturation in it of the durk green foliage during these annual inundations. The great contrast in form and color between the forests of the Rio Neyro and those of the Amazous arises from the predominance in each of different families of plants. On the main river palms of twenty or thirty different species form a great proportion of the mass of trees, while on the Rio Negro they play a very subordinate part. The characteristic kind in the latter region is the Jara (Leopoldinia pulchra), a species not found on the margins of the Amazons, which has a scunty head of fronds, with narrow leaflets of the sarne dark green hue as the rest of the forest. The stem is smooth, and about two inches in diameter; its height is not more than twelve to fifteen feet; it does not, therefure, rise among the masses of foliage of the exugenous trees, so as to form a feature in the landscape, like the broad-leaved Mura. murú and Urucrui, the slender Assai, the tall Jauari, and the fan-leaved Muriti of the banks of the Amazons. On the shores of the main tiver the mass of the forest is composed, lesides palms, of Leguminosæ, or trees of the bean fumily, in endless variety as to height, shape of foliage, flowers, and fruit ; of silkcotton-tr ees, colossal nut-trees (Lecythideæ), and Cecropix; the underwood and waterfrontage consisting in great part of broad. J'aved Musaceæ, Marantaceæ, and succulent grasses : all of which are of light shades of green. The forests of the Rio Negro are al. most destitute of these large-leaved plants and grasses, which give so rich an appearance 10 the vegetation wherever they grow ; the margins of the stream being clothed with bushes or low trees, having the same gloomy monotonous aspect as the mangroves of the shores of creeks near the Atlantic. The uniformly small but elegantly-leaved exogenous trees, which constitute the mass of the forest, consist in great part of members of the Laurel, Myrtle, IBignoniaceous, and Rubiaceous orders. The soil is generally a stitf loam whuse chief component part is the Tabatinga clay, which also forms low cliffs on the coast in some places, where it ovcrlies strata of coarse sandstone. This kind of soil and the same geological formation prevail, us we have seen, in many places on the banks of the Amazons, so that the great contrast in the forest clothing of the two rivers cannot arise from this cause.

The forest was rery pleasant for rambling. fn some directions bioad pathways led down gentle slopes, through what one might fancy were interminable shrubberies of evergreens, to moist hollows where springs of water bubbled up, or shalluw brooks ran over their beds of clean white sund. But the most beautiful road was one that ran through the heart of the forest to a waterfall, which the eitizens of Barra consider as the chief natural curiosity of their neighborhood. The waters of one of the larger rivulets which traverse the gloomy wilderness here fall over in ledige of rock aoout ten feet bish. It is cus cascade itself, but the noiseless solitude, ant the marvellous diversity and richness of trees, foliage, and flowers, encircling the water basin, that form the attraction of the place Families make picnic excursions to this spot; and the gentlemen-it is said the ladies also -spend the sultry hours of mid-day buthing in the cold and bracing waters. The place is classic ground to the naturalist, from having been a favorite spot with the celebrated travellers Spix and Martius, during their stay at Barra in 1820. Von Martius wus so much impressed by its magical beauty that he commemurated the visit by making a sketch of the scenery serve as background in one of the plates of his great work on the palms.

Birds and insects, however, were scarce amid these charming sylvan scenes. I have often traversed the whole distance from Barra to the waterfall, about two miies by the forest road, without seeing or hearing a bird, ur meeting with so many as a score of Lepidopterous and Coleopterous insects. In the thinner woods near the borders of the forest many pretty little blue and green creepers of the Dacnidæ group were daily seen feeding on berries, and u few very hundsome birds occurred in the forest. But the latter were so rare that we could obtain them only by employing a native hunter, who used to spend a whole day and go a great distance to obtain two or three specimens. In this way I obtained, among others, specimens of the Trogon pavoninus (the Suruqua graude of the natives), a most beautiful creature, having soft golden-green plumage, red breast, and an orange-colored beak; also the Ampelis Pompadoura, a rich glossy-purple chatterer with wings of a snowy-white hue.

After we had rested some weeks in Barra, we arranged our plans for further explorations in the interior of the country. Mr. Wallace chose the Rio Negro for his next trip, and I agreed to take the Solimoens. My colleague has already given to the world an account of his journey on the Rio Negro, and bis adventuruus ascent of its great tributary the Uapés. I left Barra for Ega, the first town of any importance on the Solimoens, on the 26th of March, 1850. The distance is nearly 400 miles, which we accomplished in a small cuberta, manned by ten stout Cucama Indians, in thirty-five days. On this occasion I spent twelve months in the upper region of the Amazons; circumstunces then compelled me to return to Pará. I revisited the same country in 1855, and devoted threa years and a half to a fuller exploration of its natural productions. The results of buth journeys will be given together in subsequent chapters of this work ; in the meantime I will proceed to give an account of Santarem and the river Tapajos, whose neighborhoods I investigated in the years $1851-4$.

A few words on my visit to Pará in 1851 may be here introduced. I descended the river from Ega to the capital, u distance of 1400 miles, in a heavily-laden schooner belonging to a tader of the former place. The 
voyage occupsed no less than twenty-nine days, although we were favored by the powerful currents of the rainy seasun. The hold of the vessel was tilled with turtle oil contained in large jars, the cubin was crammed with Brazil-nuts, and $u$ great pile of sarsaparilla, covered with a thutch of palm-leaves, uccupied the middle of the deck. We had therefore (the master and two passengers) but rough accommudation, having to sleep on deck, exposed to the wet and stormy weather, under little toldos or arched shelters, arranged with mats of woven lianas and maranta-leaves. I awoke many a morning with clothes and bedding soaked through with the rain. With the exception, however, of a slight cold at the commencement, I never enjoyed better health than during this juurney. When the wind blew/ from up river or off the land, we sped away at a great rate; but it was often squally from those quarters, and then it was not safe to hoist the sails. The weather was generally calm, a motionless mass of leaden clouds covering the sky, and the broad expanse of waters flowing smoothly down with no other motion than the ripple of the current. When the wind cume from below, we tacked down the stream; sometimes it blew very strong, and then the schooner, having the wind abeam, labored through the waves, shipping often heavy seas which washed everything that was loose from one side of the deck to the other.

On urriving at Pará, I found the once cheerful and healthful city desolated by two terrible epidemics. The yellow fever, which visited the place the previous year $(1850)$ for the first time since the discovery of the country, still lingered, after having carried off neariy five per cent of the population. The number of persons who were attacked, namely, threefourths of the entire population, showed how general is the onslaught of an epidemic on its first appearance in a place. At the heels of this plague came the small-pox. The yellow fever had fallen most severely on the whites and mamelucos, the negroes wholly escaping ; but the small-pox attacked more especially the Indians, negroes, and people of mixed color, sparing the whites alnost entirely, and taking off about a $t$ wentieth part of the population in the course of the four months of its stay. I heard many strange accounts of the yellow fever. I believe Parí was the second port in Brazil attacked by it. The uews of its ravages in Bahia, where the epidemic first appeared, arrived some few days before the disease broke out. The Government took all the sanitary precautions that could be thought of ; among the rest was the singular one of firing cannon at the street corners, to purify the air. Mr. Norris, the American consul, told me the first cases $u f$ fever occurred near the port, and that it spread rapidly and regularly from house to house, along the streets which run from the waterside to the suburbs, taking about Iwenty-four hours to reach the end. Somo persons related that for several successive erenings befure the fever broke out the at- mosphere was thick, and that a body of murky vapor, accompanied by a strung stench, travelled from street to street. This moving vapor was called the "Maî da pcste" (" the mother or spirit of the plague") ; and it was useless to attempt to reason them out of the belief that this was the forerunner of the pestilence. The progress of the disease was very rapid. It commenced in April, in the midale of the wet season. In a few days, thousands of persons lay sick, dying, or dead. The state of the city during the time the fever lasted may be easily inagined. Toward the end of June it alsated, and very few cases occurred during the dry season from July to December.

As I said befure, the yellow fever still lin. gered in the place when I arrived from the interior in April. I was in hopes I should escape it, but was not so fortuuate ; it seemed to spare no new-cumer. At the time I fell ill, every medical man in the place was worked to the utmost in attending the victims of the other epidemic ; it was quite useless to think of obtaining their aid, so I was obliged to bo my own doctor, as I had been in many former smart attacks of fever. I was seized with shivering and vomit at nine o'clock in the moruing. While the people of the house went down to the town for the medicines I urdered, I wrapped myself in $a$ blanket and walked sharply to and fro along the veranda, drinking at intervals a cup of warm tea, made of a bitter herb in use among the natives, called Pajémarióba, a leguminous plant growing in all waste places. About un hour afterward I took a good draught of a decoction of elder-blossoms as a sudorific, and soon after fell insensible into my hammock. Mr: Phillips, an English resident with whom I was then lodging, came home in the afternoon and found me sound asleep and perspiring famously. I did not wake till toward midnight, when I felt very weak and aching in every bone of my body. I theu took as a purgative a small rose of Epsum Silts and manna. In furty-eight hours the fever left me, and in eight days from the first attack I was able to get about my work. Little else happened during my stay, which need be recorded here. I shipped uff all my collections to England, and received thence a fresh supply of funds. It took me several weeks to prepare for my second and longest journey into the interior. Mv plan now was first to make Santarem headquarters for some time, and ascend from that place the river Tapajos, as far as practicable. Afterward I iutended to revisit the marvellous cnuntry of the Upper Amazons, and work well its natural history at various stations I had fixed upon, from Ega to the fout of the Andes.

\section{CHAPTER VIII.}

\section{SANTAREM.}

Situation of Santarem-Manners and Customs of the Inhabitants-Climute-Grassy Campos and Woods -Excursions to Mapirí. Mahicá, and Irurá, with Sketches of their Natural History; Palms, wild Fruit-treee, Mining Wasps, Masen 'Wasp8, Bees, and Sloths. 
I HAVi already given a short account of the size, situation, and general appearance of Santarem. Although contuining not more than 2500 inhabitants, it is the most civilized and important settlement on the banks of the main river from Peru to the Atlantic. The pretty little town, or city as it is called, with its rows of tolerably uniform whitewashed and red-tiled houses, surrounded by green gardens and woods, stands un gently sloping ground on the eastern side of the Tapajos, close to its point of junction with the Amazons. A small eminence on which a fort has been erected, but which is now in a dilapidat. ed condition, overlooks the streets, and forms the eastern limit of the mouth of the tributary. The Tapajos at Santarem is contractct to a breadth of about a mile and a half by sn accretion of low alluvial land, which f rms a kind of delta on the western side ; fifteen miles further up the river is seen at its full width of ten or a dozen miles, and the magnificent hilly country through which it flows from the south, is then visible on both sluores. This high land, which uppears to be a continuation of the central table-lands of Brazil, stretches almost without interruption on the eastern side of the river down to its mouth at Santarem. The scenery, as well is the soil, vegetation, and animal tenants of this region, are widely different from those of the flat and uniform country which borders the Amuzons along most part of its course. After travelling week after week on the main river, the aspect of Santarem, with its broad white sandy beach, limpid lark-green waters, and line of picturesque Thills rising behind over the fringe of green forest, affords an agreeable surprise. On the inain Amazons the prospect is monotonous unless the vessel runs near the sliore, when the wonderful diversity and beauty of the vegetation afford constant entertainment. Otherwise, the unvaried, bruad yellow stream, and the long low line of furest, which dwindles away in a bruken line of trees on the sea-like horizon, and is renewed reach after reach, as the voyager advances, weary by their uniformity.

I arrived ut Santarem on my second jour. ney into the interior, in November, 1851, and made it my head-quarters for a period, as it tuıned out, of three years and a half. During this time I made, in pursuance of the plan I bad framed, many excursions up the Tapajus, sind to other places of interest in the surinanding region. On landing, I found no d fticuliy in hiring a suitable house on the outskirts of the place. It was pleusantly situaled near the beach, going toward the ildeia or Indian part of the town. The ground sloped from the back premises down to the waterside, and my little raised veranda overlooked a beautiful flower-garden, a great rarity in this country, which belonged to the neighbors. The house contained only three rnoms, one with brick and two with boarded flours. It was substantially built, like all the better sort of houses in santa- rem, and had a stuccoed front. The kitchen, as is usual, formed an outhouse placed a few yards distant from the other rooms. The rent was 12,000 reis, or about twenty. seven shillings a munth. In this country a tenant has no extra payments to make; the owners of house pruperty pay a dizimo or tithe, to the " collectoria geral," or general treasury, but with this the occupier of course has nothing to do. In engaging servants I had the good furtune to meet with a freo mulatto, an industrious and trustworthy young fellow, named José, willing to arrange with me ; the people of his family cooking for us, while he assisted ue in collecting ; he proved of the greatest service in the different excursions we subsequently made. Servants of any kind were almost impossible to be obtained at Santarem, free people being too proud to hire themselres, and slaves too few and valuable to their masters, to be let out to others. These malters arranged, the house put in order, and a rude table, with a few chairs, bought or borrowed to furnish the house with, I was ready in three or four days to commence my natural-history explorations in the neighborhood.

Santarem is a pleasant place to live in, irrespective of its society. There are no insect pests, mosquito, piúm, sand-fly, or motuca. The climate is glorious; during six months of the year, frum August to February, very little rain falls, and the sky is cloudless for weeks together, the fresh breezes from the sea, nearly 400 miles distant, moderating the great heat of the sun. The wind is sometimes so strong for days together that it is difficult to make way against it in walking along the streets, and it enters the open windows and doors of houses, scattering loose clothing and papers in all directions. The place is considered healthy, but at the changes of season severe colds and ophthalmia are prevalent. I found three Englishmen living here, who had resided many years in the town or its neighborhood, and who still retained their flurid complexions ; the plump and fresn uppearance of many of the middle-aged Santarem ladies also bory testimony to the healthfulness of the climate. The streets ure always clean and dry, even in the height of the wet season; good urder is always kept, and the place pretty well supplied with provisiuns. Very good bread was hawked round the town every morning, with milk, and a great varisty of fruits and vegetables. Among the fruits there was a kind called atta, which I did not see in any other part of the country. It belongs to the Anonaceous order, and the tree which pro duces it grows apparently wild in the neighborhood of Santarem. It is a little larger than a good-sized orange, and the rind, which incloses a mass of rich custardy pulp, is scaled like the pineapple, but green when ripe, and incrusted on the inside with sugar. To finish this account of the advantages of Santarem, the delicious bathing in the clear waters of the Tapajos may be mentioned 
There is here no fear of alligators. When the east wind blows, a long swell rolls in on the clean sandy beach, and the bath is most exhilarating.

The country uround Santarem is not clothed with dense and lof ty forest, like the rest of the great humid river plain of the Amazons. It is a cumpo region; a slightly elevated and undulating tract of land, wooded only in patches, or with single scattered trees. A good deal of the country on the borders of the Tapajos, which flows from the great campo area of Interior Brazil, is of this description. It is un this account that I consider the eastern side of the river, toward its mouth, to be a northern prolongation of the continental land, and not a purtion of the alluvial flats of the Amazons. The soil is a coarse gritty sand ; the substratum, which is visible in sorne places, consisting of sadstone - conglomerate probably of the same formation as that which underlies the Tabatinga clay in other parts of the river valley. The surface is carpeted with sleuder hairy grasses, untit for pasture, growing to a uniform height of about a foot. The patches of wood look like copses in the middle of green meadows ; they are called by the natives " ilhas de mato," or islands of jungle; the name being, no doubt, : suggested by their compactness of outline, neatly demarcated in insular form from the smooth curpet of grass around them. They are composed of a great variety of trees. loaded with succulent parasites, and lashed together by woody climbers like the forest in other parts. A narrow belt of dense wood, similar in character to these ilhas, and like them sharply limited along its borders, runs - everywhere parallel and close to the river. In crossing the campo, the path from the town ascends a little for a mile or two, passing through this marginal strip of wood; the grassy land then slopes gradually to a broad valley, watered by rivulets. whose banks are clothed with lofty and luxuriant forest. Beyond this, a range of hills extends : as far as the eye can reach toward the yet untrodden interior. Some of these hills are long ridges, wooded or bare; others are isulated conical peaks, rising abruptly from the valley. The highest are probably not more than a thousand feet above the level of the river. One remarkable hill, the Serra de Muruarú, about fifteen miles from Santarem, which terminates the prospect to the south, is of the sume truncated pyramidal form as the range of hi'ls near Almeyrim. Complete solitude reigns over the whole of this stretch of beautiful country. The inhabitants of Santarem. know nothing of the interior, and - seem to feel little curiosity concerning it. A few tracks from the town across the campo lead to some small clearings four or five miles off, belonging to the poorer inhabitants . of the place; but, excepting these, there are no roads, or signs of the proximity of a civilized settlement.

The appearance of the campos changes very much according to the season. There is not that grand uniformity of aspect tnroughout the year which is observed in the virgin furest, and which makes a deeper impression on the naturalist the longer he re. mains in this country. The seasons in this part of the Amazons region are sharply con. trasted, but the difference is not so great as in some tropical countries, where, during the dry monsoon, insects and reptiles go into a summer sleep, and the trees simultaneously shed their leaves. As the dry season ad. vances (August, September), the grass on the campos withers, and the shrubby vegetation near the town becomes a mass of parched yellow stubble. The period, however, is not one of general orpidity or repose for animal or vegetable life. Birds certainly are not so numerous as in the wet season, but some kiuds remain and lay their eggs at this time -for instance, the ground doves (Chamæpelia). The trees retain their verdure through. out, and many of them flower in the dry months. Lizards do not become torpid, and insects are seen both in the larva and the perfect states, showing that the aridity of the climate has not a general influence on the de. velopment of the species. Some kinds of butterflies, especially the little hair-streaks (Theclæ), whose caterpillars feed on the trees, make their appearance only when the dry season is at its height. The land molluses of the district are the only animals which æstivate; they are found in clusters, Bulimi and Helices, concealed in hollow trees, the mouths of their shells closed by a film of mucus. The fine weather breaks up often with great suddenness about the beginning of February. Violent squalls from the west, or the opposite direction to the trade-wind, then occur. They give very little warning, ana the first generally catches the people unprepared. They fall in the night, and klow. ing directly into the harbor, with the first gust sweep all vessels from their anchorage ; in a few minutes a mass of canoes, large and small, including schooners of fifty tons burden, are clashing together, pell-mell, on the beach. I have reason to remember these storms, for I was once caught in one myself, while crossing the river in an undecked boat, about a day's journey from Santarem. They are accompanied with terrific electric explo. sions, the sharp claps of thunder falling almost simultaneously with the blinding flashes of lightning. Torrents of rain follow the first outbreak ; the wind then gradually abates, and the rain subsides into a steady drizzle, which continues often for the greater part of the succeeding day. After a week or two of showery weather the uspect of the country is completely changed. The parched ground in the neighborhood of Santarem breaks out, so to speak, in a rasl of greenery : the dusty, languishing trees gain, without having shed their old leaves, a new clothing of tender green foliage; a wonderful variety of quick growing leguminous plants spring up, and leafy creepers overrun the ground, the bushes. and the trunks of trees. One is reminded of the sudden adrent of spring after a few warm showers in northern climates; I was 
the more struck by it as nothing similar is witnessed in the virgin forests among which I had passed the four years previous to my stay in this part. The grass on the campos is renewed, and many of the campo trees, especially the myrtles, which grow abun. dantly in one portion of the district, begin to flower, attracting by the fragrance of their blossoms a great number and variety of insects, more particularly Coleoptera. Many kinds of birds, parrots, toucans, and barbets, which live habitually in the forest, then visit the open places. A few weeks of comparytively dry weather generally intervene in March, after a month or two of rain. The heaviest rains fall in April, May, and June; they come in a succession of showers, with sunny gleamy weather in the intervals. June and July are the months when the leafy luxuriance of the campos, and the activity of life, are at their highest. Most birds have then completed their moulting, which ex tends over the period from February to May. The flowering shrubs are then mostly in bloom, and numberless kinds of Dipterous and Hymenopterous insects appear sinultaneously with the flowers. This season might be considered the equivalent of sum. mer in temperate climates, as the bursting. forth of the foliage in February represents the spring ; but under the equator there is not that simultaneous march in the annual life of animals and plants which we see in high latitudes ; some species, it is true, are dependent upon others in their periodical acts of life, and go hand-in-hand with them, but they are not all simultaneously and similarly affected by the physical changes of the seasons.

I will now give an account of some of my favorite collecting places in the neighborhood of Santarem, incorporating with the description a few of the more interesting observations made on the natural history of the localities. To the west of the town there was a pleasant path along the beach to a little bay, callled Mapirí, uhout five miles within the rnouth of the Tapajos. The road was practicable only in the dry season. The river at Santarem rises on the average abuut thirty feet, varying in different years about ten feet; so that in the four months, from April to July, the water comes up to the edge of the marginal belt of wood already spoken of. This Mapirí excursion was most pleasant and profituble in the months from January to Niarch, before the rains became too continuous. The sandy beach beyond the town is very irregular; in some places forming long spits on which, when the east wind is blowing, the waves break in a line of foam; at others receding to shape out quiet little bays and pools. On the outskirts of the town a few scattered huts of Indians and colored people are passed, prettily situated on the margin of the wiite beach, witls a background of glorious foliage ; the cabin of the pure-blood Indian being distinguished from the mud hovels of the tre. negroes and mulattoes by its light consisuve tion, half of it being an open shed, where the dusky tenants are seen at all hours of the day lounging in their open-meshed grass. hammocks. About two miles on the road we come to a series of shallow pools, culicd the Laguinhos, which are connected with th: river in the wet season, but separaterl from it at other times by a high bank of sayl topped with bushes. There is a break here in the fringe of wood, and a glimipse is obtained of the grassy campo. When th? waters have risen to the level of the pools, this place is frequented by many kinds of wading birds. Snow-white egrets of two species stand about the maryins of the watcr, and dusky-striped herons may be seen lialt hidden under the shade of the bushes. Tlie pools are covered with a small kind of waterlily, and surrounded by a dense thicket. Among the birds which inhabit this spot is the rosy-breasted Troupial (Trupialis Guianensis), a bird resembling our starling in size and habits, and not unlike it in color, with the exception of the rich rosy vest. The water at this time of the year overflows a large level tract of campo burdering the pools, and the Troupials come to feed on the larvæ of insects which then abound in the moist soil.

Beyond the Laguinhos there succeeds a tract of level beach, covered with trees which form a beautiful grove. About the month of April, when the water rises to this level, the trees are covered with blossom and a handsome orchid, an Epidendron, with large white flowers, which clothes thickly the trunks is profusely in bloom. Several kinds of kingfisher res.rt to the place : four species may be seen within a small space: the largest as big as a crow, of a mottled.gray hue. and with an enormous beak ; the smallest not larger than a sparrof:. The large one makes its nest in clay cliffs, three or four miles distant from this place. None of the kingfishers are so brilliant in color as our English species. The blossoms on the trees attract two or three species of humming-birds. the mast cunspicuous of which is a iarge swallow-tailed kind (Eupetomena macroura), with a briliiant livery of emerald green an: 1 steel blue. I noticud that it did not remain so long poised in the air before the fluwers as the other smaller species; it perche I more frequently, and sometimes darted aiter small insects on the wing. Emerging from the grove there is a long stretch of sandy beach ; the land is bigh and rocky, and the belt, of wood which skirts the river banks is mucn broader than it is elsewhere. At length. after rounding a projecting bluff, the biay of Mapiri is reached. The river view is characteristic of the Tapajos: the shores are wooded, and on the opposite side is a line of clay cliffs, with hills in the background clothed with a rolling forest. A long spit of sand extends into mid-river, beyond which is an iminense expanse of dark water, the further shore of the Tapajus being barely visible as a thin gray line of trees on the borizun The trausparency of air and water 
In the dry season when the brisk east wind is blowing, and the sharpness of outline of hills, woods, and sandy beaches, give a great charm to this spot.

While resting in the shade during the great heat of the early hours of afternoon, I used to find amusement in watching the proceedings of the sund wasps. A small pale green kind of Bembex (Bembex ciliata) was plentiful near the bay of Mapiri. When they are at work a number of little jets of sand are geen shouting over the surface of the sloping banks. The little miners excavate with their fore feet, which are strongly built and furnished with a fringe of stiff bristles; they work with wonderful rapidity, and the sand thrown out beneath their bodies issues in continuous streams. They are solitary wasps, each female working on her own account. After making a gallery two or three inches in length, in a slanting direction from the surface, the owner backs out and takes a few turns round the orifice, apparently to see whether it is well made, but in reality, $I$ believe, to take note of the locality, that she may find it again. This done the busy workwoman flies away; but returns, after an ab- sence varying in different cases from a few minutes to un hour or more, with a fly in her grasp, with which she re-enters her mine. On again emerging the entrance is carefully closed with sand. During this interval she has laid an egg on the body of the fly, which she had previously benumbed with her sting, and which is to serve as food for the soft footless grub soon to be hatched frum the egg. From what I could make out the Bembex makes a fresh excavation for every - egg to be deposited; a. least, in two or three of the galleries which I opened there was only one fly inclosed.

I have said that the Bembes on leaving her mine took note of the locality : this seemed to be the explanation of the short delay previous to her taking flight; on rising in the air, also, the insects generally flew ruund over the place before making straight off. Another nearly allied but much larger species, the Monedula signata, whose habits I observed on the banks of the Upper Amazons, sometimes excavates its mine solitarily on sand-banks recently laid bare in the mid. dle of the river, and closes the orifice before going in search of prey. In these cases the insect has to inake a juurney of at least half a mile to procure the kind of thy, the Motúca (Madrus lepidotus), with which it provisions its cell. I often nuticed it to take a few turns in the air round the place before starting ; on its return it made without hesitation struight for the closed mouth of the mine. I I was convinced that the insects noted the bearings of their nests, and the direction they took in flying from them. The proceeding in this and similar cases (I have read of something analogous having been noticed in hive bees) seems to be a mental uct of the same mature as that which takes place in ourselves when recognizing a locality. The senses, however, must be immeasurably more keen, and the mental operation much more certain, in them than they ure in man; for to my eye there was absolutely no land-mark on the even surface of sand which could serve as guide, and the borders of the forest were not nearer than half a mile. The action of the wasp would be suid tu be instinctive; but it seems plain that the instinct is no mysterious and unintelligible agent, but a mental process in each individual, differing from the same in man only by its unerring certainty. The mind of the insect appears to be so constituted that the impression of external objects, or the want felt, causes it to act with a precision which seems to us like that of a machine constructed to move in a cortain given away. I have noticed in Indian boys a sense of locality almost as keen as that possessed by the sund-wasp. An old Portuguese and my. self, accompanied by a young lad about ten years of age, were once lost in the forest in a most solitary place on the banks of the main river. Our case seemed hopeless, and it did not for some time occur to us to consult our little companion, who had been playing with his bow and arrow all the way while we were hunting, apparently taking no note of the route. When asked, however, he pointed out, in a moment, the right direction of our canoe. He could not explaun how he knew ; I believe he had noted the course we had taken almost unconsciously. The sense of locality in his case seemed instinctive. The Monedula signata is a good friend to travellers in those parts of the Amazons which are infested by the bloodthirsty Motùra. I first noticed its habit of preying on this fly one day when we landed to make our fire and dine on the horders of the forest adjoining a saud-bank. The iusect is as large as a hornet, and has a most waspish appear. ance. I was rather startled when one out of the flock which was hovering about us flew straight at my face : it had espied a Motúca on my neck, and was thus pouncing upon it. It seizes the tly not with its jaws, but with its fore and middle feet, and carries it off tightly held to its breast. Wherever the traveller lands on the Upper Amazons in the neighborhood of a sand-bank he is sure to be attended by one or more of these useful vermin-killers.

The bay of Mapiri was the limit of my day excursions by the river-side, to the west of Santarem. A persun may travel, however, on foot, as Indians frequently do, in the dry season for fifty or sixty miles alnng the broad clean sanily beaches of the Tupajos. The only obstacles are the rivulets, most of which are fordable when the waters are low To the east my rambles extended to the banks of the Mahicá inlet. This enters the Amazons about three miles below Suntarem, where the cleur stream of the Tapajos begius to be dis. colored by the turbid waters of the main river. The Mahicá has a broad margin of , rich level pasture, limited on each side by the 
struight, tull hedge of forest. On the Santarem side it is skirted by high wooded ridges. A landscape of this description always produced in une an impression of sadness and loneliness; which the giant virgin forests that closely hedge in most of the by-waters of the Amazons never creuted. The pastures are destitute of flowers, and also of animal life, with the exception of a few small plaincolored birds and solitary Caracíra eagles, whining from the topmost branches of dead trees on the forest burders. A few settlers have built their palm-thatched and mudwalled huts on the banks of the Mahica, and occupy themselves chiefly in tending small herds of cattle. They seemed to be all wretchedly poor. The oxen, however, though small, were sleek and fat, and the district was most promising for agricultural and pastoral employments. In the wet season the waters gradually rise and cover the meadows, but there is plenty of room for the removal of the cattle to higher yround. The lazy and ignorant people seem totally unable to profit by these advantages. The houses have no yardens or plantations near them. I was told it was useltss to plant anything, because the cattle devoured the young shoots. In this country grazing and planting are very rarely carried on together, for the people seem to have no notion of inclosing patches of ground for cultivation. They say it is too much truuble to make inclosures. The construction of a durable fence is certainly $?$ difficult matter, for it is only two or three kinds of tree which will serve the purpose in being free from the attacks of insects, and these are scattered far and wide through the woods.

Although the meadows were unprodurtive ground to 9 naturalist, the woods on their borders teemed with life; the number and variety of curious insects of all orders which occurred here was quite wonderful. The belt of forest was intersected by numerous pathways leading from one settler's house to another. The ground was moist, but the trees were not so lofty or their crowns so densely packed together as in other parts; the sun's light and heat therefore had freer access to the soil, and the underwood was much more diversified than in the virgin forest. I never saw so many kinds of dwarf palms together us here; pretty miniature species; some not more than five feet high, and bearing little clusters of round fruit not larger than a good bunch of currants. A few of the forest trees had the size and strongly-branched figures of our oaks, and a similar burk. One noble palm grew here in great abundance, und yave a distinctive character to the district. This was tho Enocarpus distichus, one of the kinds called Bacába by the natives. It grows to a height of forty to fifty feet. The crovrn is of a lustrous dark-green color, and of a singularly flattened or compressed shape; the leaves being ar. ranged on each side in nearly the same plane. When $i$ first saw this tree on the campus, where the east wind blows with great Iuice right and day for several months, 1 thought: the shape of the crown was due to the leuves: being prerented from radiating equally by the constant action of the breezes. But the plane of growth is not always in the direction. of the wind, and the crown has the same shape when the tree grows in the sheltered Woods. The fruit of this fine palm ripens toward the end of the year, and is much esteemed by the natives, who manufacture a. pleasant drink from it similar to the assai de. scribed in a former chapter, by rubbing wff the coat of pulp from the nuts, and mixing it with water. A bunch of fruit weighs. thirty or forty pounds. The beverage has a. milky appearance, and an agreeable nutty fluvor. The tree is very difficult to climb, on account of the smoothness of its stem; consequently the natives, whenever they want a bunch $\mathrm{c} f$ fruit for a bowl of Bacálua, cut down and thus destroy a tree which has taken a scure or two of years to $\mathrm{grc} \mathrm{r}^{-\cdots}$, in order to get at it.

In the lower part of the Mahica wnods, toward the river, there is a bed of stiff waite clay, which supplies the people of Santarem with material for the manufacture of coarse pottery und cooking utensils ; all the kettles, saucepaus, mandioca ovens, coffee-pots, washing-vessels, and so forth, of the poorer classes throughout the country, are made of this same plastic clay, which occurs at short intervals over the whole surface of the Amazons valley, from the neighhorhoud of Pará to within the Peruvian borders, and forms part of the great Tabatinga marl deposit. To enable the vessels to stand the fire the bark of a certain tree, called Caraipé, is burned and mixed with the clay, which gives tenacity to the ware. Caraipe is an article of commerce, being sold, packed in baskets, at he shops in most of the towns. The shallow pits, excavated in the marly soil at Mahicá, were very attractive to many kinds of mason bees and wasps, who made use of the clay to build their nests with. So that we have here another example of the curious aualogy that exists between the arts of insects and tliose of man. I spent many an hour watching their proceedings : a short account of the habits of some of these busy creatures may be interesting.

The most conspicuous was a large yellow and black wasp, with a remarkably long and narrow waist, the Pelopæus tistularis. This species collected the clay in little round pellets, which it curried off, after rolling them into a convenient shape, in its mouth. It came straight to the pit with a loud lium, and on alighting lost not a moment in be. ginning to work; finishing the kneading of its little load in two or three minutes. The nest of this wasp is shaped like a puuch, two inches in length and is attached to a branch or uther prujecting object. One of lhese restless artificers once began to build on the handle of a chest in the cabin of my cauoe, when we were stationary at a place for several days. It was so intent on its work that it allowed me to inspect the invements of 
Its mouth with a lens whlle it was lylng on the mortar. Every fresh pellet was brought in with a triumphant song, which changed to a rheerful busy hum when it alighted and began to work. The little bull of moist clay whs laid on the edge of the cell, and then spread out around the circular rim, by means of the lower lip guided by the mandibles. The insect placed itself astride over the rim t) work, and, on finishing each addition to the structure, took a turn round, putting the sides with its feet inside and out before $f$ y. ing off to gather a fresh pellet. It worked only in sunny weather, and the previous layer was sometimes not quite dry when the new coating was added. The whole structure takes about a week to complete. I left the place before the gay little builder had quite finished her task; she did not accompany the canoe, although we moved along the bank of the river very slowly. On open. ing closed nests of this species, which are common in the neighborhood of Mahicá, I always found them to be stocked with small spiders of the genus Gustracanthu, in the usual half-dead state to which the mother wasps reduce the insects which are to serve as food for their progeny.

Besides the Pelupæus there were three or four kinds of Trypoxylon, a genus also found in Europe, and which some nuturalists have supposed to be parusitic, because the legs are not furnished with the usual row of strong bristles for digging, characteristic of the family to which it belongs. The species of Trypoxylon, however, are all building wasps ; two of them which I observed (T. albitarse and an undescribed species) provision their nests with spiders, a third (T. aurifrons) with small caterpillars. Their habits are similar to those of the Pelopæus: namely, they carry off the clay in their mandibles, and have a different song when they hasten uway with the burden from that which they sing while at work. Trypoxylon albitarse, which is a large black kind, three quarters of an inch in length, makes a tremendous fuss while building its cell. It of ten chooses the walls or doors of chambers for this purpose, and when two or three are at work in the same place their loud humming keeps the house in an uproar. The cell is a tubular structure about three inches in length. T. aurifrons, a much smaller species, makes a neat little nest shaped like a carafe; building rows of them together in the corners of verandas.

But the most numerous and interesting of the clay artificers ure the workers of a species of social bee, the Melipona fasciculata. The Meliponæ in tropical America take the place of the true Apides to which the European hive-bee belongs, and which are here unknown; they are generally much smaller insects than the hive-bees and have no sting. The M. fasciculats is about a third shorte: than the Apis mellifica ; its colonies are com. posed of an immense number of individuals. The workers are generally seen collecting pollen in the same way us other bees but great numbers are employed gathering clay. The rapidity and precision of their movements while thus engraged are wonderful. They first scrape the clay with their jaws the small portions gathered are then cleared by the anterior paws and passed to the second pair of feet, which in their turn, convey them to the large foliated expansions of the hind shauks, which are adapted normally in bees, as every one knows, for the collection of pollen. The middle feet pat the growing pellets of mortar on the hind legs to kcep them in a compact shape as the particles are successively adder. The little hodsmen suon have as much as they can carry, and they soon fly off. I was for some time puzzled to know what the bees did with the clay; but I hud afterward plenty of opportunity for as. certaining. They construct their combs in any suitable crevice in trunks of trees or perpendicular banks, and the clay is required to build up a wall so as to close the gap, with the exception of a small orifice for their swn entrance and exit. Most kiuds of Meliponæ are in this way masons as well as workers in wax and pollen-gatherers. One little species (undescribed), nut more than two lines long, builds a neat tubular gallery of clay, kneaded with some viscid substance, outside the entrunce to its hive, besides blocking up the crevice in the tree within which it is situated. The mouth of the tube is trumpet-shaped, and at the entrance a number of the pigmy bees are always stationed, apparentlv acting as seutinels.

A hive of the Mellipona fasciculata which I saw opened, contained about two quarts of pleasantly-tasted liquid honey. The bees, as already renarker, have no sting, but they bite furiously when their colonies are disturbed. The Indian who plundered the hive was completely covered by them, they took a particular fancy to the hair of his head, and fastened on it by hundreds. I found forty. five species of these bees in different parts of the country; the largest was half an inch in length; the smallest were extremely minute, some kinds being not more than one twelfth of an inch in size. These tiny follows are often very troublesome in the woods. on uccount of their familiarity; for they settle on onc's face and hands, and, in crawling about, get into the eyes and mouth or up the nostrils.

The broad expansion of the hind shanks of bees is applied in some species to other uses besides the conveyance of clay and pollen. The femule of the handsome golden and black Euglossa Surinamensis has this palette of very large size. This species builds its solitary nest also in crevices of walls or trees; but it closes up the chinis with fragments of dried leaves and sticks, cemented together, instead of clay. It visits the caju-trees, and gathers with its hind legs a smull quantity of the gum which exudes from their trunks. To this it adds the other materials required from the neighboring bushes, and when laden flies off to its nete. 
To the south my rambles never extended further than the banks of the Irura, a stream which rises among the hills already spoken of, and running through a bruad valley, wooded along the margins of the watercourses, falls into the Tapajos at the head of the bay of Mapirí. All beyond, as before remarked, is terra incognita to the inhabitants of Santarem. The Brazilian settlers on the banks of the Amazons seem to have no tuste for explorations by land, and I could find no person willing to accompany me ou an excursion further toward the interior. Such a journey would be exceedingly diffcult in this country, even if men could be obtained willing to undertake it. Besides, there were reports of $a$ settlement of fierce runaway neyroes on the Serra de Mururarú, and it was considered unsafe to go far in that direction, except with a large armed party. I visited the banks of the Irurá and the rich woods accompanying it, and two other streams in the same neighborhood, one culled the Panéma, and the other the Urumarí, once or twice a week during the whole time of my residence in Santarem, and made large collections of their natural productions. These forest brooks, with their clear cold waters brawling over their sandy or pebbly beds, through wild tropical glens, always had a great charm for me. The beauty of the moist, cool, and luxuriant glades was heightened by the contrast they afforded to the sterile country around them. The bare or scantily wooded hills which surround the valley are parched by the rays of the vertical sun. One of them, the Pico do Irurá, forms a nearly perfect cone, rising from a small grassy plain to a height of 500 or 600 feet, and its ascent is excessively fatiguing after the long walk from Santarem over the campos. I tried it une day, but did not reach the summit. A dense growth of coarse grusses clothed the steep sides of the hill, with here and there a stunted tree of kinds found in the plain beneath. In bared places, a red crumbly soil is exposed; and in une part a mass of rock, which appeared to me, from its compact texture and the absence of stratification, to be porphyritic; but I am not geologist sufficient to pronounce on such questions. Mr. Wallace states that he found fragments of scoriæ, and believes the hill to be a volcanic cone. To the south and east of this isolated peak the elongated ridges or table-topped hills attain a somewhat greater elevation.

The forest in the valley is limiten to a tract a few hundred yards in width on each side of the different streams; in places where these run along the bases of the hills, the hill-sides facing the water are also richly wooded, although their opposite declivities ure bare, or nearly so. The trees are lofty and of great variety ; among them are colussal examples of the Brazil-nut-tree (BertholIetia ex(elsu), and the Pikia. This latter bears a large eatable fruit, curious in having a hollow chamber hetween the pu!p and the kernel, beset with hard spines, which bro duce serious wounds if they enter the skin. The eatable part appeared to me not much. more palatable than a raw potato; but the inhabitants of Santarem are very fond of it, and undertaize the mast toilsome joúrneys on foot to gather a basketful. The tree which yields the tonka bean (Dipteryx odorata), used in Europe for scenting snuff, is also of frequeut occurrence here. It grows to an immense height, and the fruit, which, although a legume, is of a rounded shape, and has but one seed, can be yathered only when it falls to the ground. A considerable quantity (from 1000 to 3000 pounds) is exported annually from Santarem, the produce of the whole region of the Tapajos. An endless diversity of trees and slurubs, some beautiful in flower and foliage, others bearing curious fruits, grow in this matted wilderness. It would be tedious to enumerate many of them. I was much struck with the variety of trees with large and diversely shaped fruits growing out of the trunk and branches, some within a few inches of the ground, like the cacao. Most of them are called by the natires Cupú, and the trees. are of inconsiderable height. One of them, called Cupú-uí, bears a fruit of elliptical shape and of a dingy earthen color, six or seven inches long, the shell of which is. woody and thin, und contains a small number of seeds loosely enveloped in a juicy pulp. of very pleasant flavor. The fruits hang. like clayey ants' nests from the branches. Another kind more nearly resembles the cacao; this is shaped something like the cucumier, and has a yreen ribbed husk. It . bears the name of Cacao de macaco, or monkey's chocolate, but the seeds are smallerthan those of the common cacao. I tried once or twice to make chocolate from them. They contain plenty of oil of similar fragrance to that of the ordinary cacao-nut, and make up very well into paste ; but the bever. age has a repulsive clayey crlor and an in. ferior flavor.

My excursions to the Irur sad always a picnic character. A few rude huts are scattered through the valley, but they are tenanted only for a few days in the year, when thcir owners come to gather and roast the mandioca of their smali clearings. We used. generally to take with us two boys-one negro. the other Indian-to carry our provisions for the day ; a few pounds of beef or fried fish farinha, and bananas, with plates, and kettle for cooking. José carried the guns, ammunition, and game-bags, and $I$ the appa. ratus for entomologizing - the insect net, a large leathern bag with compart ments for corked boxes, phials, glass tubes, and so. forth. It was our custom to start snon after sunrise, when the walk over the campos was. cool and pleasant, the sky without a cluud, and the grass wet with dew. The paths are mere faint tracks ; in our early excursions it. was difficult to avoid missing our way. We were unce completely lust, und wandered about for several hours over the scurching soil without recovering the road. A fine: 
Vlew is obtained of the country, from the rising ground about half way across the waste. -Thence to the bottom of the valley is a long, gentle, grassy slope, bare of trees. The strangely-shaped hills; the forest at their feet, richly varied with palms; the bay of Mapiri on the right, with the dark waters of the Tapajos and its white glistening shores, are all spread out before one, as if depicted on canvas. The extreme transparency of the atmosphere gives to all parts of the landscape such clearness of outline that the idea of distance is destroyed, and one fancies the whole to be almost within reach of the hand. Descending into the valley, a small brook has to be crossed, and then half a mile of sandy plain, whose vegetation wears a pecu. liar aspect, owing to the predominance of a stemless pulm, the Curuá (Attalea spectabilis), whose large, beautifully pinnated, rigid leaves rise directly from the soil. The fruit of this species is similar to the cocoanut, con. taining milk in the interior of the kernel, but it is much inferior to it in size. Here, and indeed all along the road, we saw on most days in the wet season tracks of the jaguar. We never, however, met with the animal, although we sumetimes heard his loud "hough" in the night, while lying in our hammocks at home, in Santarem, and knew he must be lurking somewhere near us.

My best huntiug ground was a.part of the valley sheltered on one side by a steep hill, whose declivity, like the swampy valley beweath, was clothed with magniticent forest. We used to make our, halt in a small cleared place, tolerably free from ants and close to the water. Here we assembled after our toilsome morning's hunt in different direc. tiuns through the woods, took our well-earued meal on the ground-two broad leaves of the wild banana serving us for a tablecloth-and rested for a couple of hours during the great heat of the afternoon. The diversity of animal productions was as wonderful as that of the vegetable forms in this rich loculity. It was pleasant to lie down during the hottest part of the day, when my people lay asleep, and watch the movements of unimals. Sometimes a troop of Aanús (Crotuphaga), a glossy black-plumaged bird, whish lives in suall societies in grassy places, would come in from the campus, one by one, calling to each other as they moved from tree to tree. Or a Tuucan (Rhamphastos ariel) silently hopped or ran along and up the branches, peeping iato chinks and crevices. Notes of solitary birds resounded from a distance through the wilderness. Occasionally a sulky Trogon would be seen, with its brilliant green back and rose-colored breast, perched for an hour without moving on a low branch. A number of large fut lizards, two feet long, of a kind called by the natives Jacuara (Teius teguexim) were always observed in the still hours of mid-day scampering with great clatter over the dead leaves, apparently in chase of each other. The fat of this bulky lizard is much prized by the natives, who apply it as a poultice to draw palm spines or eren yrains of shot from the flesh. Other !izards of repulsive aspect, about three feet in length when full grown, splashed about and swam in the water: sometimes emerging to crawl intu hollow trees on the banks of the stream, where I once found a female and a nest of eggs. The lazy flupping ti'ght of large blue and black morpho butterflies high in the air, the hum of insects, and many inanimate sounds, contributed their share to the totai impression this strange solitude prodused. Heavy fruits from the crowns of trees which were mingled together at $r$ giddy height overheud, fell now and then with a startling "plop" into the water. The breeze, not felt below, stirred in the topmost branches, setting the twisted and looped sipós in motion, which creaked and groaned in a great variety of notes. To these noises was added the monotowous ripple of the brook, which had its little cascade at every score or two yards of its course.

I seldom met with uny of the larger uni. mals in these excuirsions. We never saw a muminal of any kind on the cumpos; but tracks of three species were seen occusionally besides those of the jaguar; these belonged to a small tiger-cat, a deer, and an opossum ; all of which animais must have been very rare, and probably nocturnal in their habits, with the exception of the deer. I saw in the woods, on one nccasion, a small flock of monkeys, and once had an opportunity of watching the movements of a sloth. The latter was of the kind called by Cuvier Bradypus tridactylus, which is clothed with shagyy gray hair. The natives call it, in the Tupí language. Ar ybyreté (in Portuguese, Preguiça da terra firme), or sloth of the mainlund, to distinguish it from the Bradypus infuscatus, which has a long black and tawny stripe between the shoulders, and is called Arygupó (Preguiça das vargens), or sloth of the flooded lasds. Some travellers in South America have described the sloth as very nimble in its native woods, and have disputed the justness of the name which has been bestowed npon it. The inhabitants of the Amurzons region, however, both Indians and descendants of the Purtuguese, hold to the common opinion, and consider the sloth as the type of laziness. It is very common for one native to call another, in reproaching him for idleness, "bicho de Embauba" (beast of the Cerropia tree); the leavas of the (ecropia being the foud of the sloth. It is a strange sight to watch the uncouth creature, fit production of these silent shades, lazily muving from branch to hranch. Every movement botrays, not indolence exactly, but extreme caution. He never luses his hold from one branch without first securing himself to the next, and when he does not immediately find a bough to grasp with the rigid hooks inte which his paws are so curiously transformed. he raises his body, supported on his hind legs, and claws around in search of a fresh foothold. After watching the animal foc about half an hour I gave him a charge of shut : he fell with a terrific crash, but 
caught a bough, in his descent, with his powerful claws, and remained suspencled. Our Indian lad tried to climb the tree, but was driven back by swarms of stinging unts; the poor little fellow slid down in a sad predicament, and plunged into the brook to) free himself. Two days afterward I found the body of the sloth on the ground: the azimal having dropped on the relaxation of the muscles u few hours after death. In one of our voyages Mr. Wallace and I saw a sloth (B. infuscatus) swimming across a river, at a place where it was probably 300 yards broal. I believe it is not generally known that this animal takes to the water. Our men caught the beast, cooked, and ate him.

In returning from these trips we were sumetimes benighted on the campos. We did not care for this on mounlit nights, when there was no danger of losing the path. The great heal felt in the middle hours of the day is much mitigated by four o'clock in the aftermon ; a few birds then make their apnearance; small tlocks of ground duves run about the stony hillucks; parrots pass over and sometimes settle in the ilhas; pretty little finches of several species, especially one kind, streaked with olive-brown and yellow, and somewhat resembling our yellow-hammer, but, I believe, not belonging to the same genus, hop about the gruss, enlivening the place with a few musical notes. The Carashué (Mimus) also then resumes its mellow hlackbird-like song; and two or three species of humming-bird, none of which, however, are peculiar to the district, flit about from tree to tree. On the other hand, the little blue and yellow-striped lizards, which abound among the herbage during the scorching heats of mid-day, retreat toward this buur to their hiding-places; together with the day-tlying insects and the numerous campo-butterflies. Some of these latter resemble greatly our English species found in healthy places, namely, a fritillary, Argynuis (Euptoieta) Hegesia, und two smaller kinds, which are deceptively like the little Nemeobius Luciua. After sunset the air becomes delightfully cool and fragrant with the aroma of fruits and flowers. The nocturnal animals then come forth. A monstrous hairy spider, tive inches in expanse, of a brown color, with yellowish lines along its stout legs - which is very common here, inhabiting broad tubular galleries smoothly lined with silken web-may be then caught on the watch ot the mouth of its burrow. It is only seen at night, and I think does not wander far from its den ; the gallery is about two inches in diameter, and runs in a sianting direction, about two feet from the surface of the soil. As soon as it is night, swarms of youat-suckers suddenly make their appearance, wbeeling about in a nuiseless, ghostly mauner, in chase of night-flying insects. They sunietimes descend and settle on a low brauch, or even on the pathway close to where one is walking. and then, Eyuating down on their heels, are difficult to distinguish from the surrounding soil. One: kind lias a long forked tail. In the day-timethey are concealed in the wooded ilhas, where I very often saw them crouched and sleeping. on the ground in the dense shade. They make no uest, but lay their eggs on the bare ground. Their brecding time is in the raicy season, and fresh eggs are found from De. cember to June. Later in the evening tho singular notes of the goat-suckers are heard. one species crying Quao, Quao, unother Chuck-co-co-cro ; and these are repeatert ut intervals far into the night in the most mo notonous manner. A great number of toads are seen on the bare sandy pathways sook after sunset. One of them was quite a colng sus, about seven inches in length and three ir height. This big fellow would never miove out, of the way until we were cluse to him. If we jerked him out of the path with a stick, he would slowly recover himself, and then turn round (1) have a good impudent stare. I have counted as many as thirty of ihese monsters within a distance of half a mile.

\section{CHAPTER IX.}

VOYAGE UP THE TAPAJOS.

Preparations for voyuge-First day's sail-Loss of boat-Altar do Chuo-Modes of obtaining fish-Difficulties with crew-Arrival at Aveyros-Excursionsin the neighborhood-White Cebus and habits und dispusitions of Cebi monkeys-Tame parrot-Missionary s:ttlement-Enter the River Cuparí-Adven. ture with an anacondn-Smoke-drled monkey-Bos constric'ur-Villare of Mnnclurncé Indians, and in. cursion of a wild tribe-Fulls of the Cuparí-Hia cinthine macaw-Ke-emerge into the broad Tapajo -Descent of river to Santarem.

June, 1852.- I will now proceed to re late the incillents of iny principal excursion up the Tapajus. which I began to prepare for after residing about six months at Santarem.

I was obligeci, this time, to travel in a vessel of my own : partly because trading. canuts large enorgh to accommodute a naturalist very seldım pass between Santarem and the thinly-peopled settlements on the. river. and paitly because I wished to explore districts at my ease far out of the ordinary truck of traders. I soun found $a$. suitable canoc-a two-masted cuberta, of abrut six tons' burden, strongly built of Itaübu or stonewood, a timber of which all the best vessels in the Amazons country are constructed, anil said to be more durablia than teak. This I hired of a merchant at the cheap rate of 500 reis, or about one shilling and twopence per day. I fitted up the. cabin, which, as usual in canoes of this class, was a square structure with its floor above the water-line, as $m y$ sleeping and working apartments. My chests, filled with sture-boxes and trays for specimens, were arranged on each side, and abuve them were shelves and pegs to hold my little stock of useful books, guns, and game bags, boasds. and materials for skinning and preserving animals, botanical pross and papers, drying. rages for insects und birls, und su forth. $\AA$ rinsh init was spread on the floor aud my idi-uj hummock, to be uted only when. 


\section{THE NATURALIST ON THE RIVER AMAZONS.}

sleeping ashore. served for a pillow. The srched covering over the hold in the forepart of the vessel contained, besides a sleeping place for the crew, my hency chests, stock of salt provisinns anil groceries, and an assortment of gonds wherewith to pay $m$ - way among the half-civilized or savage 1 - iabit. ants of the interinr. The goods consisted of easchaça powder and shnt, a few pieces of coarse checked-rotton ciotl and prints, fish-liooks, axes, large knives, harpoons, arrow heads, looking.glasses, bends, and other small wares. José and myself were busy for many days arranging these matters. We had to salt the ineat and grind a supply of coffee ourselves. Cooking utensils, crockery, water jars, a set of useful carpenter's tools, and many other things had to be provided. We put all the givecises and other perishable articles $i$, tin cuuisters and hoxes, having found that this was the nnly way of preserving them from $\mathrm{d} \mathrm{mp}$ and insects in this climite. When all was done, our canoe looked like a little flouting workshop.

I coulc? get little information about the river, except vague accounts of the difficulty of the navigation and the famito or hunger which reigned on its banks. As I have before mentioned. it is aliout a lhousand miles in length, and flows from south to north ; in magnitude it stands the sixth among the tributaries of the Am:ıons. It is navigable, however, by suling vessels only for alout 160) miles ahove Santarem. The hiring of men to navigate the vessel was our greatest trouble. José was to be my helmsman, and we thought three other hands would be the fewest with which we conld venture. But all our endeavors to procure these were funitless. Sintarem is worse provided with Indian canoemen than any other town on the river. I found on applying to the tradesmen to whoin I hal brought letters nf introduction, and to the Brazilian authorities, that almost any favor would be sooner granted than the loun of hands. A stranger, liowever, is obliged to depent on them ; for it is impossible $t$, tin 1 an Indian or half caste whom some one or other of the headmen do not clatm as owing him money or labor. I was africl at one time I should have been forcerl to abardion my project on this account. At length, after many rebuffs and disappointments, José contrived to engage one mau, a mulatto, named Pinto. a nutive of the mining country of Interior Brazil, who knew the river well; and will these two I resolved to start, hoping to meet with others at the first village on the rond.

We left Santarem on the $8 \mathrm{th}$ of June. The waiers were then ut their highest point, and $\mathrm{my}$ c:anoe had been anchored close to the back door of our house. The murning was cool, and a bisk wind blew, with which we sped rapidly past the whitewasheil houses and thatched Indian huts of the suburbs. The charming little bav of Mapiré was soon left behind: we then doubled Point Maria Jusepha, a headland formed of high cliffs of Tabatinga clus, cappect with forest.
This forms the limit of the rive: view from Santarem, an? here we hat our last glimpse, at a distance of seven or eight miles, of tho city, a bright line of tiny white buildings resting on the dark water. A stretch of wild, rocky, uninhabited coast was before us, and we were fairly within the Tapajos.

Our course lay due west for ubout twenty miles. The wind increased as we neare! Point Cururú, where the river bends from its northern course. A vast expanse of water here stretches to the west and soutb. and the waves with a strong breeze run very high. As we were doubling the point the cable which held our montari: in tow astern parted, and in endeavoring to recover the boat, without which we knew it would be diflicult to get ashore on many parts of the coast, we werc very near capsizing. $\mathrm{W}_{3}$ tried to tack down the river, a vain attempt with a strong breeze and no current. Ou* ropes snapped, the sails flew to rags, and the ressel, which we now found was deficient in hallast, hecled over frightfully. Con. trary to José's advice, I ran the cuberta into a little bay, thinking to cast anchor there an? wait for the bnat cuming up with the wind but the anchor diagged on the smooth sandy bottom, and the vessel went broadside on $t$. the rocky bcach. With a little dexterous management, but not until after we had sus tainey snrye scvere bumps, we manuged to get out of this difliculty, elearing the rocky point at a close shave with our jib-sail. Soon ufter we difted isto the smooth wate of a sheltered bay, which leads to the charmingly situated village of Altar do Chao ; anil we were obligred to give up our attempt $t$, reciver the montaria.

The little settlement, Altar do Chao (Altar of the ground, or Earth altar), owes its singular name to the existence, at the entranco to the harbor, of one of those strange flat. topped hills which are so common in this part of the Amazons country, shaped lik's the high altar in Ruman Catholic churches. It is an isulated one, and much lower 1:? beight than the similarly truncated hills an I ridges near Aineyrim. being elevated prol,ably not inore than 300 teet above the lev. of the river. It is bare of trees, but coverc I in places with a species of fern. At the hea of the bay is an inner harbor, which cons. municates by a channel with a series of laks s tying in the valleys between hills, an stretching far into the interior of the land. The village is peopled almost entirely $b_{y}$ semi-civilized Indians, to the number of sixt ? or seventy fumilies ; and the scattered housi y are arrunged in bruad streets on a strip ot greenswarn, at the foot of a high, glorious! $f$ wooded ridge.

I was so much pleased with the situation nf this settlement, and the number of ra!c: birds and inseets which tenanted the forcst, that I revisited it in the following year, an. $l$ spent four months making collections. $\mathrm{Tl}$ : houses in the village swarmed with vermin : bats in the thatch ; fre-ants (formigu de fog (1) undser the floors; cockroaches and spidess 
on the wirs. Very few of them had wooden doors and locks. Altar do Chao was originally a settlement of the aborigines, and was called Burari. As in all the semi-civil. ized villages, where the original orderly and industrious habits of the Indian have been lost without anything being learned from the whites to make amends, the inhabitants live in the greatest poverty. The scurcity of fish in the clear waters and rocky bays of the neighborhood is no doubt purtly the cause of the poverty and perennial hunger which reign here. When we arrived in the port our cunoe was crowded with the half-naked villagers-men, women, and children-who came to beg each a piece of salt pirarucu "for the love of God." They are rot quite so badly off in the dry season. The shallow lakes and bays then contain plenty of fish, and the boys and women go out at night to spear them by torchlight. the torches being made of thin strips of green bark from the leaf-stalks of palms, tied in bundles. Many excellent kinds of fish are thus obtained, among them the Pescada, whose white and flaky flesh, when boiled, has the appearance and flavor of codfish; and the Tucunare (Cichly temensis), a handsonie species with a large prettily-colored eye-like spot on its tail. Many small Salmonidæ are also met with, and a kind of solc, called Aramussá, which moves alung the clear sandy bottom of the bay. At these times a species of sting-ray is common on the sloping beach, and bathers are frequently stung most severely by it. The weapon of this fish is a strong blade with jagged edges, abuut three inches long, growing from the side of the long fleshy tail. I once saw a woman wounded by it while bathing ; she shrieked frightfully, and was obliged to be carried to her hammock, where she lay for a week in great pain. I have known strong men to be lamed for many months by the sting.

There was a mode of taking fish here which I had not before seen employed, but found afterward to be very common on the Tapajos. This is by using a poisonous liana culled Timbó (Paullinia pinuata). It will act unly in the still waters of. creeks and pools. A few rods, a yard in length, are mashed and soaked in the water, which quickly becomes discolored with the milky, deleterious juice of the plant. In about half an hour all the smaller fishes over a ruther wide space around the spot rise to the surface, tloating on their sides, and with the gills wide open. The poisun acts evidently by suffocuting the fishes; it spreads slowly in the water, and a very slight mixture seems sufficient to stupefy them. I was surprised, on beating the water in places where no fighes were visible in the clear depths, for many yards round, to find, sooner or later, sometimes twenty-four hours ufterward, a considerable number fluating dead on the surface.

The climate is rather more humid than that of Santarem. I suppose this is to be attriubted to the neighboring country being densely wooded, instead of an open campo. In no part of the country did I enjoy more the moonlit nights than here in the dry season. After the day's work was done I used to go down to the shores of the bay and lie fnli length on the cool sand for two or three hours before bedtime. The soft pale light, resting on broad sandy beaches and palmthatched huts, reproduced the effect of a midwinter scene in the ccid north when a roating of snow lies on the landscape. A heavy shower falls about once a week, and the shrubby regetation never becomes parched up as at Santarem. Between the rains the heat and dryness increase from day to day : the weather on the first day after the rain is gleamy, with intervals of melting sunshine and passing clouds; the next day is rather drier, and the east wind begins to blow ; then follow days of cluudless sky, with gradually increasing strength of breeze. When this has continued about a week a light mistiness begins to gather about the horizon, clouds are formed, yrumbling thunder is heard, and then, generally in the nighttime, down falls the refreshing rain. The sudden chill caused by the rains produces colds, which ure accompanied by the same symptoms as in our ow'n climate; with this exceptinr, the place is very healthy.

June 17th. - The two young men returned without meeting with my montaria, and I found it impossible here to buy a new one. The lead-man could find me only one hand. This was a blunt-spoken but willing young Indian, named Manoel. He came on board this morning at eight o'clock, and we then got up our anchor and resumed our voyage.

The wind was light and variable all duy, and we made only about fifteen miles by seven v'clock in the evening. The coust formed a succession of long shallow bays with sandy beaches, on which the waves broke in a long line of surf. Ten miles above Altar do Chao is a conspicuous head. land, called Point Cajetaba. During a lull of the wind, toward mid-day, we ran the cuberta aground in shalluw water and waded ashore, but the woods were scarcely penetrable, and not a bird was to be seen. The only thing observed worthy of note was the quantity of drowned winged ants along the beach : they were all of one species, the terrible formiga de fogo (Myrmica sævissima); the dead or half-dead bodies of which were heaped up in a line an inch or two in height and breadth, the line continuing without in. terruption for miles at the edge of the water. The countless thousands had been doubtless cast into the river while flying during a sudden squall the night hefure, and afterward cast ashore by the waves. We found our. selves at seren 0 clock near the mouth of a creek leading to a small lake, called Aramána-í and the wind having died away, we anchored, guided by the lights ashore, near the house of a settler named Jeronymo, whom I knew, and who soon after showed us a snug little harbor where wo could re- main in safety for the night. The river here 
eannot be less than ten miles broad; it is quite clear of islands, and free from shoals at this season of the year. The opposite coast appeared in the caytime as a long thin line of forest, with dim gray hills in the background.

June 20th.-We had a light baffling wind off shore all day on the $20 \mathrm{th}$, and mude but fourteen or fifteen miles by six P.M., when, the wind failing us, we anchored at the mouth of a narrow channel, called Tapaiúna, which runs between a large island and the mainland. About three o'clock we passed in front of Buim, a village on the opposite (western) cuast. The breadth of the river is here six or seven miles : a confused patch of white on the high lund opposite was all we saw of the village, the separate houses being undistinguishable on account of the distance. The coast along which we sailed to-day is a continuation of the low and flooded land of Paquiatúba.

June 21st.- The next morning we suiled along the Tapaiúna channel, which is from 400 to 600 yards in breadth. We advanced but slowly, as the wind was generully dead against us, and stopped frequently to ramble ashore. Wherever the landing place was sandy it was impossible to 'walk about on account of the swarms of the terrible fire-ant, whose sting is likened by the Brazilians to the puncture of a red-hot needle. There was scurcely a square inch of ground free from them. About three P.M. we glided into a quiet, shady creek, on whose banks an industrious white settler had located himself. I resolved to pass the rest of the day and night here, and endeavor to obtain a fresin supply of provisions, our stock of salt beef being now nearly exhausted. The situation of the house was beautiful, the little harbor being gay with water plants, Pontederiæ, now full of purple blossom, from which flocks of stilt-legged water-fowl started up screaming as we entered. The owner sent a boy with my men to show them the lest place for fish up the creek, and in the course of the evening sold me a number of fowls, besides baskets of beans and farinha. The result of the fishing was a good supply of Jandiá, a hundsome spotted Siluride fish, and Piránha, a kind of salmon. Piránhas are of several kinds, muny of which ahound in the waters of the Tapajos. They ure caught with almost any kind of bait,for their taste is indiscriminate and their appetite most ravenous. They often attuck the legs of bathers near the shore, inflicting severe wounds with their strong triungular teeth. At Paquiatúbu und this pluce I added about twenty species of small fishes to my collection, caught by hook and line, or with the hand in shallow pools under the shade of the forest.

My men slept ashore, and on the coming aboard in the morning Pinto was drunk and insolent. According to José, who had kept himself sober, and wus alarmed at the other's violent conduct, the owner of the house and Pinto had spent the greater part of the night together, drinking aguardente de beijú, и spirit distilled from the mandioca root. We knew nothing of the antecedents of this man, who was a tall, strong, self-willed fellow, and it beyan to dawn on us that this was net a very safe travelling companion in a wild country like this. I thrught it better now to make the best of our way to the next settlement, Aveyros, and get rià of him. Ourr course to-day lay along a high rocky coast, which extended without a hreak fur about eight miles. The height of the perpendicular rocks was from 100 to 150 feet ferus and flowering shrubs grew in the crevices, and the summit supported a luxuriant growti of forest, like the rest of the river banks. The waves beat with loud roar at the fuot c.f these inhospitable barriers. At two P.M. W 3 passed the mouth of a small picturesque har. bor, formed by a gap in the precipitous coast. Several families have here settled; the place is called Itá-puáma, or " standing rock," from a remarkable isolated cliff which stands erect at the entrance to the little haven. A short distance beyond ltá-puáma we found ourselves opposite to the village of Pinhel, which is perched, like Boim, on high ground, on the western side of the river. The stream is here from six to seven miles wide. A line of low islets extends in front of Pinhel, and a little farther to th? south is a larger island, called Capitari, which lies nearly in the middle of the river.

June $23 d$ - The wind freshened at $t \in \mathrm{n}$ o'ciock in the morning of the 23d. A thick black cloud then began to spread itself ove: the sky along way down the river; the storn which it portended, however, did not reach us, as the dark threatening mass crossel from east to west, and the only effect it ha I was to impel a column of cold air up the river, creating a breeze with which we bounded rapidly forward. The wind in th: afternoon strengthened to a gale; we carried on with one foresail only, two of the men holding on to the boom to prevent the whole thing from flying to pieces. The rocky coast continued for about twelve miles above Itá-puáma, then succeeded a tract of low marshy land, which had evidentiy becn on:e an islund whose channel of separation from the mainland had become silted up. The island of Capitarí, and another group i $f$ islets succeeding it, called Jacaré, on the opposite side, helped also to contract at this point the breadth of the river, which wis now not more than ubout three miles. The little cuberta almust flew along this coast, there being no perceptible current, past extensive swamps, margined with thick flonting grasses. At length, on rounding a low puint, higher land again appeared on the right bank of the river, aud the village of Aveyros hove in sight, in the port of which we cast anchor late in the afternoon.

Aveyros is a small settlement, containing only fuurteen or fifteen houses besides the church; but it is the place of residence uf the authorities of a large district-the priest Juiz, de Paz, the subdelegado of police aL 1 
the Captain of the Trabalhadores. The district includes Pinhel, which we passed about twenty miles lower down on the left bank of the river. Five miles beyoud Aveyros, and aiso on the left bank, is the missionary village of Sunta Cruz, comprising thirty or forty families of baptized Mundurucú Indiaus, who are at present under the management of a Capuchin Friar, and are independent of the Captain of Trabalhadores of Aveyros. The river view from this point toward the south was very grand; the stream is from two to three miles broad, with green islets resting on its surface, and on each side a chain of hills stretches away in long perspective. I resolved to stay here for a few weeks to muke collections.

On landing, my first care was to obtain a house or rooin, that I might live ashore. This was soon arranged, the head man of the place, Captain Antonio, having received notice of my coming, so that before night all the chests and apparatus I required were housed and put in order for working.

I here dismissed Pinto, who again got drunk and quarrelsome a few hours after he came ashore. He left the nexi day, to my great relief, in a small trading canoe that touched at the place on its way to Suntarem. The Indian Manoel took his leave at the same time, having engaged to accompany me only as far as Aveyros; I was then dependent on Captain $\Lambda$ ntonio for fresh hands. The captains of Trabalhadores are appointed by the Brazilian Government, to embody the scattered Indian laborers and canoe-men of their respective districts, to the end that they may supply passing travellers with me' when required. A semi-military organization is given to the bodies, some of the steadiest among the Indians themselves being nominated as sergeants, and all the members mustered at the principal village of their district twice a year. The captains, however, universally abuse their authority, monopo. lizing the service of the men for their own purposes, so that it is only by favor that the loan of a cuno-hand can be wrung from them. I was treated by Captain Antonio with great consideration, and promised two good Indians when I should be ready to con. tinue my voyage.

Little happened worth narrating during my forty days' stay at Aveyros. The time was spent in the quiet, regular pursuit of natural history ; every morning I had my long ramble in the forest, which extended to the back-doors of the houses, and the afternoons were occupied in preserving and studying the objects collected. The priest wus a lively old man, but rather a bore from being able to talk of scarcely anything except homoepathy, having been smitten with che mania during a recent visit to Santarem. He had a Portuguese Homcupethic Diction. ary, and a little leather case containing glass tuves filled with globules, with which he was doctoring the whole village. The weather, during the month of July, was un. interruptedly fine; not a drop of rain fell, and the river sank rapidly. The mornings, for two hours after sunrise, were very cold? we were glad to wrap ourselves in blankets on turning out of our hammocks, and walk about at a quick pace in the early sunshine. But in the afternoons the heat was sickening, for the glowing sun then shone full on the front of the row of whitewashed houses, and there was seldom any wind to moderate its effects. I began now to understand why the branch rivers of the Amazons were so unhealthy while the main strearn was pretty nearly free from diseases arising from mala. ria. The cause lies, without doubt, in the slack currents of the tributaries in the dry season, and the absence of the cooling A mazonian trade-wind, which purifies the air along the banks of the main river. The trade-wind does not deviute from its nearly straight westerly course, so that the branch. streams, which run generally at right angles to the Amazons, and have a slack current for a long distance from their mouths, are left to the horrors of nearly stagnant air and water.

Aveyros may be called the headquarters of the fire-ant, which might be fittingly termed the scourge of this fine river. The Tapajos is nearly free from the insect pests of otlier parts, mosquitoes, sand-flies, motúcas, and piums ; but the formiga de fogo is perhaps a greater $p^{\prime}$ ague than all the others put together. It is found ouly cn sandy soils in open places, and seems to thrive most in the Leighborhoud of houses and weedy villages such as Aveyros : it does not occur at all in the shades of the forest. I noticed it in most places on the hanks of the Amazuns, but the species is not very common on the main river, and is presence is there scarcely noticed, because it dnes not attack man, and the sting is not so virulent as it is in the same species on the banks of the Tapajos. Aveyros was deserted a few years before my visit on account of this little tormentor, and the inhubitants had only recently returned to their houses, thinking its numbers had decreased. It is a small species, of a shining reddish color not greatly differing from the common red stinging ant of our own country (Myrmica rubra), except that the pain and irritation caused by its sting are much greater. The soil of the whole village is undermined by it : the ground is perforated with the entrances to their subterranean galleries, and a little sandy dome occurs here und there, where the insects bring their young to receive warmth near the surface. The houses are overrun with them; they dispute every fragment of food with the inhabitants, and destroy clothing for the sake of the starch. All eatables are obliged to be suspended in baskets from the rafters, and the cords well soaked with copaüba baisam, which is the only means known of preventing them from climbing. They seem to attack persons out of sheer malice: if we stood for a few moments in the street,even at a distance from their nests, we were sure to be overrun and severely punished. for the moment an ant t,uched the 
rlesh he secured himself with his jaws, doubled in his tail, and stung with ull his might. When we were seated on chairs in the evenings in front of the house to enjoy a chat with our neighbors, we had stools to support our feet, the legs of which, as well as those of the chairs, were well anointed with the balsam. The cords of hammicks - sre ohliged to be smeared in the same way to prevent the ants from paying sleepers a visit.

The inhabitants declare that the fire-ant was unknown on the Tapajos before the dis. orders of 1835-6, and believe that the hosts sprang up from the blood of the slanghtered Cabanus or rebels. They have, duubtless, increased since that tine, but the cause lies in the depopulation of the villages and the rank growth of weeds in the previouslycleared, well-kept spaces. I have already described the line of sediment formed, on the sandy shores lower down the river, by the dead bodies of the winged individuals of this species. The exodus from their nests of the males and females takes place at the end of the rainy season (June), when the swarms are blown into the river by squalls of wind, and subsequently cast ashore by the waves. I was told that this wholesale destruction of ant-life takes place unnually, and that the same compact heap of dead bodies, which I saw only in part, extends along the banks of the river for $t w f l v e$ or fifteen miles.

The forest behind Aveyros yielded me little except insects, but in these it was very rich. It is not too dense, and broad sunny paths, skirted by luxuriant beds of Lycopodiums, which form attractive sporting places for insects, extend from the village to a swampy hollow or ygapó, which lies about a mile inlund. Of butterflies alone I enumerated fully 305 species, captured or seen in the course of forty days, within a half-hour's walk of the village. This is a greater number than is found in the whole of Eurupe. The only monkey I observed was the Callithrix moloch, one of the kinds called by the Indians Whaiápu-saí. It is a moderate-sized species, clothed with long brown hair, and liaving hands of a whitish hue. Although near?y allied to the Cebi, it has none of their resiless vivacity, but is a dull, listless animal. it goes in small flocks of five or six individli:ts, running along the main boughs of the Irees. One of the specimens which I obtained here wis caught on a low fruit-tree at the back of our house at sunrise one mornin:s. This was the only instance of a in'snkey being captured in such a position that I ever heard of. As the tree was isolated, it raust huve descended to the ground from the neighburing forest, and walked somo dis. tance to get at it. The species is sometimes kept in a tame state by the natives : it does not make a very aınusing pet, und survives captivity only a short time.

I heard that the white Cehus, the Caiarára branca, a kind of monkey I had not yet seen, and wished very much to obtain, inhabited the forests on the opposite side of the river; so one diy, on an opportunity being affurded by our host going over in a large boat, I crossed to go in search of it. We were about twenty persons in all, sad the boat was an old rickety affuir, with the gaping seams rudely stuffed with tow and pitch. In addition to the human freight we took three sheer with us, which Captain Antonio had just re. ccived frow Santarem, and was going to add to his new cattle farm on the other side. Ten Indian paddlers carried us quickly across. The breadth of the river could not be less than three iniles, and the current was scarcely perceptible. When a bout has to cross the main Amazons it is ubliged to ascend along the banks for half a mile or mure to allow for drifting by the current; in this lower part of the Tapajos this is not necessary. When about halt way, the sheep, in moving about, kicked a hole in the bottom of the boat. The passengers took the matter very coolly, although the water spouted up alarnı. ingly, and I thought we should inevitubly be swamped. Captain Antonio took off bis socks to stop the leak, inviting me and the Juiz de Paz, who was one of 'he party, to do thc same, while two Indiaus baled ort the water with large cuyas. We thus managed to keep afloat until we reached our destination, when the men putched up the leak for our return journey.

The lunding-place lay a short distance within the mouth of a shady inlet, on whose banks, hidden among the dense woods, were the houses of a few Indian and mumeluco settlers. The path to the cattle farm led first through a tract of swampy forest : it then ascended a slope and emerged on a fine sweer of prairie, varied with patches of timber. The wnoded portion occupied the hollows where the soil was of a rich chocolate-bruwr color, and of a peaty nature. The higher grassy, undulating purts of the campo had 8 lighter and more sandy soil. Leaving ous friends, I and José took our guns and dived into the woods in search of the monkeys. As we walked rapidly along I was very neas treading on a rattlesnuke, which lay stretchea out nearly in a straight line on the bare sandy pathway. It made no movement to get out of the way, and I escaped the danger by a timely and sudden leap, being unable ts check my steps in the hurried walk. W6 tried to excite the sluggish reptile by throw. ing handfuls of sand and sticks at it, but the only notice it took was to raise its ugly horny tail and shake its rattle. At length it began to move rather nimbly, when we dispatched it by $a$ blow on the head with a pole, not wishing to fire on account of alarming our ganie.

We saw nothing of the white Caiarára we met, however, with y flock of the common light-hrown allied species (Cebus albifrons?), and killed one as a specimen. A resident on this side of the river told us that the white kind was found farther to the south, beyond Sauta Cruz. The light-brows. Caiarára is pretty generally distributed ovel the forests of the level country. I saw it very frequently on the banks of the Ipper Ama. 
zinns, where it was always a treat to watch a Hock leaping among the trees, for it is the most wonderful performer in this line of the whule tribe. The troops consist of thirty or more individuals, which travel in single file. When the foremost of the flock reaches the outermost branch of an unusually lofty tree he snrings forth into the air without a moment's hesitation, and alights on the dome of yielding foliage belonging to the neighboring tree, maybe fifty feet beneath, all the rest following the example. They grasp, on falling, with hands and tail, right themselves in a moment, and then away they go along branch and bough to the next tree. The Caiarára owes its name in the Tupí language, macaw or large-headed (Acain, head, and Arára macaw), to the disproportionate size of the head compared with the rest of the body. It is very frequently kept as a pet in houses of natives. I kept one myself for about a year, which accompanied me in $\mathrm{my}$ voyages and became very familiar, coming to me always on wet nights to share my blanket. Lt is a most restless creature, but is not playful like most of the American monkevs, the restlessness of its disposition seeming to arise from great nervous irritability and discontent. The anxious, pain. ful, and changeable expression of its countenance, and the want of purpose in its movements, betray this. Its actions are like those of a wayward child; it does not seem happy even when it has plenty of its favorite food, bananas; but will leave its own meal to snatch the morsels out of the hands of its companions It differs in these mental traits from its nearest kindred, for unother commou Cebus, fuund in the same parts of the forest, the Prego monkey (Cebus cirrhifer ?), is a much quieter and better-tempered ani$\mathrm{mal}$; it is full of tricks, but these are generally of a playful character.

The Cuiurára keeps the house in a perpetual uproar where it is kept. When alaımed, or hungry, or excited by envy, it screams piteously, it is always, however, making some noise or other, often screwing up its mouth and uttering a succession of loud notes resembling a whistle. My little pet, when loose, used to run after me, supporting itself for sume distance on its hind legs, without, however, having been taught to do it. He offended me greatly one day by killing, in ne of his jealous fits, another and much thoicer pet-the nocturnal owl-faced monkey (Nyctipithecus trivirgatus) Some one had given this a fruit, which the other coveted, so the two got to quarrelling. The Nyctipithecus fought only with its paws, clawing uut and hissing like a cat; the other soon obtained the mastery, and before I could interfere tinished his rival by cracking its skull with his teeth. Upon this I got rid of him.

difter I had obtained the two men promsard, stout young Indians, 17 or 18 yeurs of ige, cne numed Ricardo and the other Alberto, I paid a second visit to the western side of the rirer in my own cunoe, being determined, if nossible, to obtain specimeus of the wite Cebus. We crossed over first tc. the mission village, Santa Cruz, which consists of 30 or 40 wretchtd-looking mud huts. closely built together in three straight ugiv rows on a high gravelly bank. The place was: deserted, with the exception of two or three old men and women anc' a few children. h narrow belt of wood runs behind the village : beyond this is an elevated barren campo. with a clayey and gravelly soil. To the south the coast country is of a similar description; a succession of scantily-wooded hills, bare grassy spaces, and richly-timbered hollows. We traversed forest and campo in various directions during three days without meeting with monkeys, or indeed with anything that repaid us the time and trouble. The soil of the district appeared too dry; at this season of the year 1 had noticed, in otlier parts of the country, that mammals and birds resorted to the more humid areas of forest ; we therefore proceeded to explore carefully the low and partly swampy tract, along the coast to the north of Santa Cruz. We spent two days in this way, landing at many places, and penetrating a good clistance i: the interior. Although unsuccessful with regard to the white Cebus, the time was not who!ly lost, as I added several small birds of species new to my collection. On the second evering we surprised a lar ge flock, composed of sibout fifty iudividuals, of a curious eagle with a very long and slender hooked beak, the Rostrhamus hamatus. The were perched on the bushes winich surrounder a shallow lageon, separated from the river by a belt of floaing grass ; my men said they fed on toads : and lizards found at the margins of pools. They formed a beautiful sight as they flew up and wheeled about at a gieat height in the air. We obtained only one specimen.

before returning to Aveyros we paid an other visit to the Jacaré inlet, leading to Cuytain Antonio's cattle farm, for the sake of securing further specimens of the many rure and handsome insects found there, land. ing at the port of one of the settlers. The owner of the house was not at home, and the wife, a buxom young woman, a dark mameluco, with clear though dark complexion and fine rosy cheeks, was preparing, in company with another stout-built Amazon, her rod and lines to go out fishing for the day's dinner. It was now the seuson for Tucunarés. an: Senhora Joaquina showed us the fly baits used to take this kind of fish, which she had made with ber own hands of parrots' feethers. The rods used are slender bambons, and the lines made from the fibres of pireapple leaves. It is not very comman for the Indian and half-caste women to pro. vide for themselves in the way these spirited dames were doing, although they are all ex. pert paddlers, and very frequently cross wide rivers in their frail boats without the aid of men. It is possible that parties of Indiar women, seen travelling alone in this manner, may have given rise to the fable of a natios of Amazons, invented by the first Spanisk. explorers of the country. Senhora J oaquinz. 
Znvited me and José to a Tucunaré ainner for the afternoon, and then, shouldering their paddles and tucking up their skirts, the two dusky fisherwomen marched down to their canoe. We sent the two Indians into the woods to cut palm leaves to mend the thatch of our cuberta, while I and José rambled through the woods which skirted the campo. On our return we found a most bountiful spread in the house of our hostess. A spotless white cloth was laid on the mat, with a plate for each guest, and a pile of fragrant newly-made farinha by the side of it. The boiled Tucunarés were soon taken from the kettles and set before us. I thought the men must be happy husbands who owned such wives as these. The lndian and mameluco women certuinly do make excellent managers; they are more industrious than the men, and most of them manufacture farinha for sale on their own account, their credit always standing higher with the traders on the river than that of their male connections. I was quite surprised at the quantity of fish they had taken, there being suffcient for the whole party, including several shildren, two old men from a neighboring hut, and my Indians. I made our goud-natured entertainers a small present of needles and sewing-cotton, articles very much prized, and soon after we re-embarked, and again crossed the river to Aveyros.

August 2d.-Left Aveyros, having resolved to ascend a branch river, the Cuparí, which enters the Tapajos about eight miles above this village, instead of going forward along the main stream. I should have liked to visit the settlements of the Mundurucú tribe, which lie beyond the first cataract of the Tapajos, if it had been compatible with the other objects I had in view. But to perform this journey a lighter canoe than mine would have been necessary, and six or eight Indian paddlers, which in my case it was utterly impossible to obtain. There would be, however, an opportunity of seeing this fine racc of peuple on the Cupari, as a horde was located toward the head-waters of this streum. The distance from Areyros to the last civilized settlement on the Tapajos, Itaitúba, is about forty miles. The falls com. mence a shurt distance beyond this place. Ten formidable cataracts or rapids then succeed each other at intervals of a few miles, the chief of which are the Coaitá, the Buburé, the Salto Grande (abnut thirty feet nigh), and the Montanha. The canoes of Cuyabá tradesmen which descend annually to Santarem are obliged to be unlouded at each of these, and the cargoes carried by land on the backs of Indians, while the empty vessels are dragged by ropes over the obstructions. The Cupari was described to me us flowing through a rich, moist, clayey valley, covered with forests, and abounding in game, while the banks of the Tapajos beyond Areyros were barren sandy campos, with ranges of naked or scantily-wooded hills, forming a kin 1 of country which I had always found very unproductive in Nakural
History objects in the dry season, which had now set in.

We entered the mouth of the Cupari on the evening of the following day (August 3d). It was not more than 100 yards wide, lut very deep; we found no bottom ic the middle with a line of eight fathoms. The banks were gloriously wooded, the familiar foliage of the cacao growing abundantly among the mass of other trees, remiuding me of the forests of the main Amazons. We rowed for five or six miles, generully in a southeasterly direction, although the river had many abrupt bends, and stopped for the night at a settler's house, situated on a high bank, and accessible only by a flight of rudo wooden steps fixed in the clayey slope. The owuers were two brothers, half-breeds, who with their families shared the large roomy dwelling ; one of them was a blacksmith, and we found him working with two Indian lads at his forge, in an open shed under the shade of mango trees. They were the sons of a । Portuguese irnmigrant, who had settled here furty years preziously, and married a Mun. durucú woman. He must have been a far , more industrious man than the majority of his countrymen who emigrate to Brazil nowa. 1 days, for there were signs of former extensive cultivation at the back of the house, in groves of orange, lemon, and cotfee trees, and a large plantation of cacau occupied the lower grounds.

The next morning one of the brothers brought me a beautiful opossum, which had been caught in the fowl-house a little before sunrise. It was not so large as a rat. and had soft brown fur, paler beneath and on the face, with a black stripe on each cheek. This made the third species of marsupial rat I had so far obtained : but the number of these animals is very considerable in Brazil, where they take the place of the shrews of Europe, shrew mice and, indeed, the criole of the in. sectivorous order of mammale being entirely absent from Tropical America One kind of these rat-like opossums is aquatic, and has webber feet. The terrestrial species are nocturnal in their habits, sleeping during the day in hollow trees, and coming forth at night to prey on birds in their roosting places. It is very difficult to rear poultry in this country, on account of these small opossums, scarcely a night passing, in some parts, in which the fowls are not attacked by them.

August 5th.-The river reminds me of some parts of the Juburí channel, being hemmed in by two walls of forest, rising to the height of at least 100 feet, and the outlines of the trees being concealed throughout by a dense curtain of leafy creepers. The impression of vegetable profusiun and orerwhelming luxuriance increases at every step; the deep and narrow valley of the Cupart! has a moister climate than the banks of the Tapajos. We have now frequent showers, whereas we left everything parched up by the sun at Aveyros.

After leaving the last sitio we adrsaced ahout eight miles, and then stopped at the 
house of Senhor Antonio Malagueita, a cation by the Indians, seeing that thiey som urameluco settler whom we had been recom- readily become tame. The obstacle cficed mended to visit. His house and outbuildings bv their not breeding in conninement, which were extensive, the grounds well weeded, is probably owing to their aibotcal habits, and the whole wore an air of comfort and might perhaps be overcome by repeated exwell-being which is very uncommon in this penment ; but for this the Indians probably country. A bank of indurated white clay had not sufficient patience or intelligence. sloped gently up from she tree-shaded port to The reuson cannot lie in their inscnsibility to the house, and beds of kitchen-herbs extended the value of such birds; for the commun on each side, with (rare sight !) rose and jus- turkey, which has been introduced inlu tie mine trees in full bloom. Senhor Antonio, a rather tall middle-uged man, with a countenance beaming with good nature, came down to the, port as soon as we auchored. I was quite a stranger to him, but he had heard of my coming, and seemed to have made preparations. I never met with a heartier welcome. On entering the house, the wife, who had more of the Indian tint and features than her husban l, was equally warm and frank in her greeting. I stayed here two days. We hac. together several long and successful rambles along a narrow pathway which extended several miles into the for est. $I$ here met with a new insect, pest, one which the natises may be tuankful is not spread more widely over the country ; it was a large brown fly of the Tabanidæ family (genus Pangonia) with a prohoscis half an inch long and sharper than the finest needle. It settled on our backs by twos and threes at a time, and pricked us through our thick cotton shirts. making us start and cry out with the sudden pain. I secured a dozen or two as specimens. As an instance of the extremely confined ranges of certain species, it may be mentioned that $I$ did not fiul this insect in any other part of the country, except along balf a mile or so of this gloomy forest road. We were anused at the excessive and almost absurd tameness of a fine Mutum or Curassow turkey that ran about the house. It was a large glossy-black species (the Mitu tuberosa), having an orange-colored beak, surmisuinté ivy a bean-shuped excrescence of the same hue. It seemed to consider itself as one of the family : attended at all the meals, passing from one person to another round the inat to be fed, and rubbing the sides of its head in a coaxing way against their cheeks or shoulders. At night it went to ronst on a chest in a sleeping-room beside the tammock of one of the little girls, to whom - it seemed particularly attached, following her wherever she went about the grounds. I found this kind of Currasow bird was very common in the forests of the Cuparí ; but it is rare un the . Upper Amazons, where an allied species," which has a round instead of a bean-shiaped waxen excrescence on the beak (Crux globicera), is the prevailing kind. These birds in their natural state never descend from the tops of the loftiest trees,

where they live in small flocks and build their

nests. The Mitu tuberosa lays two roughshelled white eggs; it is fully as large a bird

as the common turkey, but the flesh when cooked is drier and not so well flavored. It is difficult to find the reason why these suwerl) birds have not been teduccd to domesti-

We had an unwelcome visitor while at anchor in the port of Antonio MIaiagueitu. I was awoke a little after midnight, as I lay in my little cabin, by a heavy blow struck at the sides of the canoe close to my head, which was succeeded by the sound of a weighty body plunging in the water. I got up; but all was aguin quiet, except the cackle of fowls in our hen-coup, which hung over the side of the vessel, about three feet from the cabin door. I cculd find no explanation of the circumstance, and, my men being all ashore, I turned in again and slept till morning. I then found my pnultry locse about the canoe, and a lurge rent in the bottom of the ben-coop, which was about two feet from the suifuce of the water: a couple of fowls were nissing. Senhur Antonio said the depredatur was a Sucurujú (1he Indian name for the Anaconda, ur great water seipent, Eunectes murinus), which had for muntlis past been haunting this part of the tiver, and had carried off many ducks and fowls from the ports of various houses. I was incline! to duubt the fact of a serpent striking at its prey from the water, and thought an alligator more likely to be the culprit, although we had not yet met with alligators in the river. Some days afterward the young men belonging to the different sitios agreed together to go in search of the serpent. They began in a systematic manner, forming two parties, each emiarked in thiee or four canoes, and starting from points several miles apart, whence they gradualiy approximated, searching all the little inlets on both sides the river. The reptile was found at lust, sun ning itself on a log at the mouth of a muddy rivulet, and dispatched with harpoons. I saw it the day after it was killed : it was not a very large specimen, measuring only eighteen feet nine inches in length, and sixteen inches in circumference at the widest part of the body. I measured skins of the Anacon. da afterward, twenty-one feet in length and two feet in girth. The reptile has a mist hideous appearance, owing to its being very broad in the middle, and tapering abrupt:y at both ends. It is very abundant in some parts of the country, nowhere more so than in the Lago Grande, near Santarem, where it is often seen coiled up in the curners of farmyards, and is detested for its labit of carry. ing off poultry, young calves, or whatever animal it can get within reach of.

At Ega a large Anaconda was once near making a meal of a young lad abuui teu years of age, belonging to one of my neighbors. ine futher and his son went, as was their 
cust/n, a tew miles up the Teffè to gather wild fruit; landing on a sloping sandy shore, where the boy was left to mind the canoe wiile the man entered the forest. The beaches of the Teff' form groves of wild guava and myrtle trees, and during most months of the year ure partly overflown by the river. While the boy was playing in the water under the shade of these trees, a huge reptile of this spucies stealthily wound its coils around him, unperceived until it was too late to escape. His cries brought the futher quickly to the rescue, who rushed forward, and seizing the Anaconda boldly by the head, tore his jaws asunder. There appears to be no doubt that this formidable serpent grows to an enormous bulk, and lives to a great age, for I heard of specimens having been killed which measured forty-two feet in length, or double the size of the larg. est I had an opportunity of examining. The natives of the Amazons country universally believe in the existence of a monster waterserpent, said to be many score fathoms in length, which appears successively in different parts of the river. They call it the Mai d'ayoa-the mother, or spirit, of the water. This fable, which was duubtless suggested by the occasional appearance of Sucurujús of unusually large size, takes a great variety of forms, and the wild legends form the subject of conversation am ong old and young, over the wood fires in lonely settlements.

August 6th and 7th. - On leaving the sitio of Antunia Malagueita we continued our way along the windings of the river, generally in a south-east and south-south-east direction, but somatim's due north, for about fifteeu miles, when we stopped at the house of one Paulo Christo, a mameluco whose acquaintance I had made at Aveyros. Here we spent the night and part of the next day, doing in the morning a good five hours' work in the lorest, accompanied by the owner of the lace. In the ufternoon of the 7 th we were gain unjer woigh : the river makes a bend o the east-nurth-east for a short distance เbove Paulo Christo's esta' 'ishment, it then iurns abruptly to thie south-west, -unning from that direction about four miles. The hilly country of the interior then commences, the first token of it being a magnificently wooded bluff, rising nearly straight from the water to a height of aboit 2.50 feet. The breadth of the stream hereabout was not more than sixty yards, and the forest assumed a new appearance, from the abundance of the Urucuri palm, a species which has a noble crown of broad fronds, with symmetrical rigid leaflets.

Wr ceached, in the evening, the house of the lo.st civilized settler on the river, Senhor Joa's 'John) Aracú, a wiry, active felluw aud capiail hunter, whom I wislied to make a friend of and persuade to accompany me t? the Mundurucu village and the falls of ths Cupari, some forty miles furtier up the river.

I stayed at the sitio of John Alacu until

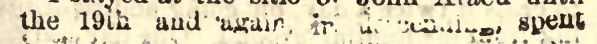

fourteen days at the same place. The situn. tiou was most favorable for collecting the natural products of the district. The forest was not crowded with underwood, and pathways fed through it for many miles and in various directicns. 1 could make no use, here of our two men us hunters, so, to keep them employed, while José und I worked duily in the woods, I set them to make a montaria under John Aracri's directions. The first day a suitable tree was found for the shell of the boat, of the kind called Itatiba amarello, the yellow variety of the stone-wood. They felled it, and shaped uut of the trunk a log nineteen feet in length : this they dragged from the forest with thit help of my host's men, over a road they hal previously made with cylindrical pieces of wood to act as rollers. The distance wits. about half a mile, and the rope used for drawing the heavy load was tough liavas cut from the surrounding trees. This part of the wori occupied about a week ; the log hail then to be hollowea out, which was done with strung chisels through a slit made down the whole length. 'The heavy portion of the task being then conipleted, Lothing remained but to widen the opening, fit two planks for the sides, and the same number of semicircular boards for the ends, make the benches, $c$ :d calk the seams.

The expanding of the $\log$ thus hollowed out is a critical operation, and not always successful, many a good shell being spoilnd by its splitting or expanding irregularly. It is first reared on trestle, with the slit downward, over a larye fire, which is kept up for seven or eight hours, the process requiring unremitting attention to avoid cracks and inake the plank bend with the proper dip at the two ends. Wooden straddlers, made hy cleaving pieces of tough elastic wood anil fixing them with wedges, are inserted into the opening, their compass being altered gradu. ally as the work goes on, but in different degree according to the part of the boat operateil upon. Our casca turnea sut a good one: it took a long rime to cool, $\varepsilon n d^{3} w^{2}$ as kept in shape while it did so by means of vrouden crosspieces. When the bout was fivished, it was launched with great merrinuent by the men, who hoisted colored handkerchiefs for flags, and paddled it up an 1 down the stream to try its capabilities. Mis people had suffered as much inconrenience. from the want of a montaria as myself, so this was a day of rejoicing to all of us.

I was very successful at this place witin regard to the objects of my journey. A bout twenty new species of fishes iud a considerabie number of small reptiles were adiled to niy collection; but very few birds were ulet with worth preserving. A great number of the most conspicuous insects of the locality were new to me, and turned out to 'be species peculiar to this part of the Amazons villey. The most interesting acquisition wus a large. and handsom monkey; of a spedies $t$ hil: not before net with-ilie white-ivliiskered. Couitá, or spilior-muakej (Atelés margíca- 
bus). I saw a pair one day in the forest mor. ing slowly along the branches of a lofty tree, and shot one of them; the next day John Aracú brought down another, possibly the companion. The species is of about the same size as the common black kind, of which I $h$ ave given an account in a former chapter, and has a similar lean body, with limbs cluthed with coarse black hair ; but it differs in having the whiskers and a triangular patch on the crown of the head of a white color. I thought the meat the best flavored I had ever tasted. It resembled beef, but had a richer and sweeter taste. During the time of our stay in this part of the Cupari we could get scarcely anything but fish to eat, and as this diet ill agreed with me, three suc- cessive days of it reducing me to a state of g reat weakness, I was obliged to make the most of our Coaitá meat. We smoke-dried the joints instead of salting them, placing them for several hours on a framework of sticks arranged over \& fire, a plan adopted by the natives to preserve fish when thes, have no salt, and which they cull " muquiar." Meat putrefies in this climate in less than twenty-four hours, and salting is of no use, unless the pieces are cut in thin slices and dried immediately in the sun. My monkeys lasted me about a fortnight, the last joint being an arm with the clinched fist, which I used with great economy, hanging it in the intervals between my frugal meals on a nail in the cabin. Nothing but the hardest necessity could have driven me so near to cannibalism as this, but we had the greatest difficulty in obtuining here a sufficient supply of animal food. About every three days the work on the montaria had to be suspended, and all hands turned out for the day to hunt and fish, in which they were often unsuccessful, for although there was plenty of game in the furest, it was too widely scat. tered to be available. Ricardo und Alberto occasionally brought in a tortoise or ant-eater, which served us for one day's consumption. We made acquaintance here with many strange dishes, among them lguana eggs; these are of oblong form, about an inch in length, and covered with a flexible shell. The lizard lays about two score of them in the hollows of trees. They have an oily taste; the men ate them raw, beaten up with farinlia, mixing a pinch of salt in the mess ; I could ouly do with them when mixed with Tucupi sauce, of which we had \& large jar. ful always ready for the tempering of unsavory morsels.

One day as I was entomologizing alone and unarmed, in a dry Ygupó, where the trees were rather wide apart and the ground coated to the depth of eight or ten inches witb dead leaves, I was near coming into collision with a boa-constrictor. I had just entered a little thicket to capture an insect, and while pinning it was rather startled by a rushing ? noise in the vicinity. I looked up to the sky, thinking a squall was coming on, but not a breath of wind stirred in the tree-tops. On stepping out of the bushes I met face to face a huge serpent coming down a slope, and making the dry twigs crack and fly with his weight as he moved over them. I had very frequently met with a smaller boa, the Cutim. boia, in a similar way, and knew from the habits of the family that there was no dan. ger, so I stood my ground. On seeing me the reptile suddenly turned, and glided ut an accelerated pace down the path. Wishing to take a note of his probable size and the culors and markings of his skin, I set off after him; but he increased his speed, and I was unable to get near enough for the purpose. There was very little of the serpentine movement in his course. The rapidly moving and shining body looked like a stream of brown liquid flowing over the thick bed of fallen leaves, rather than a serpent with skin of varied colors. He descended toward the lower and moister parts of the Ygapó. The huge trunk of an uprooted tree here lay across the roud; this he glided over in his undeviating coursc, and soon after penetrated a dense swampy thicket, where of course I did not choose to follow him.

I suffered terribly from heat and mosquitoes as the river sank with the increasing dryness of the seuson, although I made an awning of the sails to work under, and slept at night in the open air, with my hammock slung between the masts. But there was no rest in any part; the canoe descended deeper and deeper into the gully, through which the river flows between high clayey banks, as the water subsided, and with the glowing sun overhead we felt at midday as if in a furnace I could bear scarcely any clothes in the daytime, between eleven in the morning and five in the afternoon, wearing nothing but loose and thin cotton trousers and a light straw hat, and could not be accommodated in John Aracú's house, as it was a small oue and full of noisy children. One night we had a terrific storm. The heat in the afternoon had been greater than ever, and at sunset the sky had a brassy glare : the black patches of cloud which floated in it being lighted up now and then by flashes of sheet lightning. The inosquitoes at night were more than usually troublesome, and $I$ had just sunk exhausted into a doze, toward the early hours of morning, when the storm began ; a complete deluge of rain, with incessant lightning and rattling explosions of thunder. It lasted for eight hours ; the gray dawn opening amid the crash of the tempest. The rain trickled through the seams of the cabin roof on to my collections, the late hot weather having warped the boards, and it gave me immense trouble to secure them in the midst of the confusion. Altugether I had a bad night of it; but what with storms, heat, mosquitoes, hunger, and, toward the last, ill health, I seldom had a good night's rest on the Cuparí.

$\Lambda$ amall cruek traversed the forest behind John Aracú's houso, and entered the river a iow yards from our anchoring place; I used to cross it twice 2 day, on going and return. ing from my hunting-ground. One day eurly 
in September, I noticed that the water was two or three inclies higher in the afternoon than it had been in the murning This phenoinenon was repeated the next day, and in fact duily, until the creek became dry with the continued subsidence of the Cupari, the time of rising shifting a little froin day to duy. I pointed out the circumstance to John Arcaú, who had not noticed it before (it was only his second year of residence in the loculity), but agreed with me that it must be the "mare." "Yes, the tide ! the throb of the great oceanic pulse felt in this remote corner, 530 miles distant from the place where it first strikes the body of fresh water at the mouth of the Amazons. I hesitated at first at this conclusion, but on reflecting that the tide was known to be perceptible at Obydos, more than 400 miles from the sea; that at high water in the dry season a large flood from the Amazuns enters the muuth of the Tapajos, and that there is but a very smill difference of level between that point unil the Cupari, a fact shown by the absence of current in the dry season; I could have no doubt that this conclusion was a correct one.

The fact of the tide being felt 530 miles up the Amazons, passing from the main stream to one of its affluents 390 miles from its mouth, aud thence to a branch in the third degree, is a proof of the extreme flatness of the land which forms the lower part of the Amazunian valley. 'This uniformity of level is showr ulso in the broud lake-like expanses of water formed, near their mouths, by the principal affluents which cruss the valley to join tho main river.

Auguat 21st.-Tohn Aracú consented to accompany me to the falls, with one of his men, to hunt and fish for me. One of my objects was to obtain speciniens of the hyacinthine macaw, whose range cummences on all the branch rivers of the Amazons which flow froin the south through the interior of Brazil, with the first cataracts. We started on the 19th, our direction on that day being generally south-west. $\mathrm{On}$ the 20 th our course was southerly and south-easterly. This morning (August 21 st) we arrived ut the Indian settlement, the first house of which lies about thirty-one miles above the sitio of John Arucú. The river at this place is from sixty to seventy yards wide, and runs in a zigzag course between steep clayey bauks, twenty to fifty feet in height. The houses of the Mundurucús, to the number of about thirty, are scattered ulong the banks for a distance of six or seven miles. Tho owners appear to have chosen all the most picturesque sites-tracts of level ground at the foot of wooded heights, or little havens with bits of white sandy beach-as if they had an appro. ciation of natural beauty. Must of the dwellings are conical huts, with walls of framework filled in with mud and thatched with palm-leaves, the broad eaves reaching half way to the ground. Some are quadruigular, and do not differ in structure finm thuse of the semi-civi!ized settlers in other fiarts;

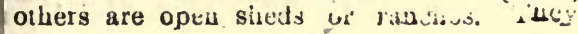

seem generally to contain not more than one or two families each.

At the first house we learned that ull the fighting men had this morning returned from a two days' pursuit of a wandering luorde of savages of the Parárauáte tribe, who had strayed this way from the interior lands and robbed the plantatious. A litile further on we came to the house of the Tushaúa, u: chief, situated on the top of a hig! bauk, which we had to ascend by wooden steps. There were four other houses in the neig!borhood, all filled with people. A fius cld fellow, with face, shoulders, and breast tattooed all over in a cross-bar pattern, was the first strange object that cuught my eye. Most of the nuen lay lounging or sleeping i: their hammocks. The women were employed in an adjoining shed making furinha, many of them being naked, and rushing off to the luuts to slip on their petticoats when they caught sight of us. Our extrance aroused the Tushaúa from a nap; after rub. bing his cyes he came forward and bade us welcome with the most formal polietness, and in very good Portuguese. He was a tall, broad-shouldered, well-made mun, upparently about thirty years of age, with handsome regular features, not tattoved, and a quiet, good-humored expression of countenance. He had been several times to Santarem and once to Pará, learning the Portuguese language during these jourueys. He was dressed in shirt and trousers made of blue. checked cottun clcth, and there was not the slightest trace of the savage in his appearance or demeanor. I was tuld that he had come into the chieftainship by inheritance, and that the Cuparí horde of Mundurucús, over which his fathers had ruled before him, was formerly much more numerous, furnishing 300 bows in time of war. They could now scarcely muster forty ; but the horde has no longer a close political connection with the muin body of the tribe, which inlabits the banks of the Tapajos, six days' jourucy from the Cupari settlement.

I spent the remainder of the day here, sending Aracu and the men to fish, while I amused myself with the Tushaúa and his people. A few words served to explain my errand on the river; he comprehenileil at once why white men should admire, aus travel to collect the beautiful birds and au:mals of his cuuntry, and neither he nor lis people spuke a single word about trading, $\omega^{\circ}$ gave us any trouble by coveting the things we had brought. He reluted to me tho erents of the preceding three days. $T_{2} e$ ¿Purárauátes were a tribe of intractable savages, with whom the Mundurucús have been ulways at war. They had no fixed abode, and of course made no plantations, but passed their lives like the wild beusts, roaming through the forest, guided by the sun : wherever they found themselves at nighttime, there they slept, slinging their bast hammocks, which are carried by the women, to the trees. They cross the streams which Iis is their course in bark cunves, which they 
make on reaching the water, and cast away -after lauding on the opposite side. The tribe is very nuinerous, but the different hordes ohey only their owu chieftains. The Mundurucús of the upper Tapajos have an expedition on font against them at the present time, and the T'ushaúa supposed that the horde which hal just been chased fium his maluca were fugitives from that direction. There were al) ut a hundred of them-including men, women, and children. Before they were discovered the hungry savages had upronted all the macasheira, sweet polatwes, and sugar-cane, whicu the industrious Mundurucús luad planted for the seasun, on the east side of the river. As soon as they were seen they made off, but the Tushaúa quickly got together all the young men of the settlemunt, about thirty in number, who armed themselves with guns, bows and arrows, und juvelins, and siarted in pursuit. They tracked them, as before related, for two days Ahrough the forest, but lost - their traces on the further bank of the Cuparitinga, a branch strearm flowing from the north-east. The puisuers thought, at one lime, they were close upon them, having found the inextinguished tire of their last encumpment. The fontmarks of the chief could be distinguished from the rest by their grcat size and the Aength of the stride. A small necklace made of scarlet beans was the only trophy of the expedition, aud this the Tushuúa yave to me.

I saw very little of the other male Indians, as they were aslecp in their huts all the ufternoon. There were two other tattooed men lying under an open shed, be sides the old man already mentiuned. One of $1 \mathrm{him}$ piesented z strange appearunce, having a semicurcular black patch in the middle of his face, covering the hottom of the nose and mouth ; crossed lines on his back and bicast, und stripes down his arms and legs. It is singular that the graceful curved patterns ust o by the South Sea 1slanders are quite unknuwn among the Brazilian red inen; they bring all $\checkmark$ attooed either in simple lines or palches. "The nearest approacls to elegance of diesign which I saw was among the Tucunac of the Upper Amazons, some of whicm have a scroll-like mark on each cheek, piscliding from the corner of the miuth. The liste, zis far as form is concerned, of the Americun Indian would scem to be far less refived than that of the Tahitian aud Now Z(r)lander.

To amuse the Tushaúa, I felched ficm the canoe the two volumes of Knight's "Pic. torial Museum of Animated Nalure." The engravings quite took his funcy, and he called his wives, of whom, as I aficiward Jearned from Aracú, he had three ot ti uı. to look at them; one of them was a linudi-. me girl, decorated with necklace and $b 1 \ldots+1,1 \mathrm{~s}$ (f blue beuds. In a short time cil : : 1t their work, and I then had a crowd, i w in. en and children around me, who all (ist) i. led unusual curiosity for Indinns. Ji n cs nol light task to go through the which (.. lie illustrations, but they would not allon 1 , to miss a page, making me turn lack whue f tried to skıp. The pictures of the elephant camels, orang-otangs, and tigers scemed most to astonish them; but they were inter. ested in almost everything, down even to the she!ls and insects. They recognized the portraits of the most striking birds and mam. puals which ate found in their own country; the jaguar, howling moukejs, parrols, troguns, und toucans. The elephant was settled to be $"$ large kind of Iapir; but they made but few remarks, and those in the Mundurucú language, of which I understood only two or three words. Their way of express. ing suıprise was a ciickilig sound made with the tieth, similar to the one we ourselves use, or a subdued exclamation, Hin ! lim ! Before I finished, from fifty to sixty had assembled ; there was no pushing or rudeness, tho grown-up women letting tlee young girls and children stand befure them, and all behaved in the most quiet and orderly manner possible.

The Mundurucús are perluaps the most numerous and formidable tribe of Indians now surviving in the $\Delta$ mazons region. They nhalit the shores of the Tapajos (chiefly the right lank), from $3^{\circ}$ to $7^{\circ}$ suuth latitude, and the interior of the country between that part of the river and the Madeira. On the Tapajos alone they can muster, I was told, 2000 fighting men; the total population of the tribe may he about 20,000. 'They were not heard of until about ninety years ago, when they murle war on the Poituguese settle. ments, their hosts crossing the interior of this country castward of the Tapajos, and at. tacking the establishments of the whites in the province of Matanhain. The Portuguese made peace with them in the beginning of the preseut $\cdot \mathrm{n}$ ury, the event being broight about by the common caluse of quarrel entertained liy the two peoples against the hated Múras. They have ever since been firm friends of the whites. It is remarkable how faithfully this friendly feeling ias been hsoded down among the Muudurucús, and spread to the remotest of the scattered hordes. Wherever a white man meets a famil:", or even un individual of the tribe, he is ulru ist sure to be reminded of this alliance. They are the must warlike of the Brazilian tribes, in 1 are cousidered also the most settle 1 an 1 in lustrious ; they are not, howerer, superior in this latter respect to the Juris and Passés, in the Upper Amuzons, or the Uapés Indians nsar the loead waters of the Ris Negro. They make very large plantations of inulioca, and sell the surplus pruduce, whirat am suats on the Tapajos to from 3000 (i) 50.0 baskets ( 60 lin. each) annially, to traders who ascend the iver from Sintalem between the inonths of Angust and Jannary. The also gather large quantities of Sals 1 parilla, in lia-rubber, nnd Touka beans, in the forests. The tradeis, on their arrival at the Caripinas (the scantily wosded region in. iabite 1 b the main body of Mundurucús beyon l lie cataricts) have first to distribats their whes-choap cottun cloths, irnn hach. ote. ery, snall warus, and cashaça- 
among the minor chiefs, and then wait three or four munths for repayment in produce.

A rapid change is taking place in the habits of these Indians through frequent intercourse with the whites, and those who dwell on the banks of the Tapajos now seldom tattoo their children. The principal Tushaúa of the whole tribe or nation, named Joaquim, was rewarded with a commission in the Brazilian army, in acknowledgment of the assistunce he gave to the legal authorities during the rebellion of $1835-6$. It would be a misnomer to call the Mundurucús of the $\mathrm{Cu}$ pari and many parts of the Tapajos, savages; their regular mode of life, agricultural habits. loyalty to their chiefs, fidelity to treaties, and gentleness of demeanor, give them a right to a better title. Yet they show no aptitude for the civilized life of towus, and, like the rest of the Brazilian tribes, seem incapable of any further advance in culture. In their former wars they exterminated two of the neighboring peoples, the Júmas and the Jacurés ; und make now an annual expedition against the Parárauátes, and ono or two other similar wild tribes who inhabit the interior of the land, but are sometimes driven by hunger toward the banks of the great rivers to rob the plantations of the agricultural Indians. These campaigns begin in July, and last throughout the dry months ; the women generally accompanying the warriors to carry, their arrows and javelins. They had the diabolical custom, in former days, of cutting off the heads of their slaiu enemies, and preserv. ing them as trophies around their houses. I believe this, together with other savage practices, has been relinquished in those parts where they have had long intercourse with the Brazilians, for I could neither see nor hear anything of these preserved heads. They used to sever the heads with knives made of broad bamboo, and then, after taking out the brain and fleshy parts, soak it in bitter vegetable oil (andiroba), and expose it for several days over the smoke of a fire or in the sun. In the tract of country between the Tapajos and the Madeira a deadly war has been for many yeurs carried on between the Mundurucús and the Aráras. I was told by a Frenchman at Santarem, who had visited that part, that all the settlements there have n military oryanization. A sepurate shed is built outside each village, where the fighting men sleep at night, sentinels being stutioned tu give the alarm with blasts of the Turé on the approach of the Aráras, who choose the night for their onslaughts.

Each horde of Mundurucús has its pajé or medicine man, who is the priest and doctor; fixes upon the time most propitious for attacking the enemy; exorcises evil spirits, and professes to cure the sick. All illness whose origin is not very apparent is supposed to be caused by a worm in the part affected. This the pajé pretends to extract; he blows on the seat of pain the smoke frum a large cigur, made with an nir of great mystery by rolling tobacco in folds of Tauari, and ther. sucks the place, drawing from his mouth. when he has finished, what he pretends to be the worm. It is a piece of very clumsy conjuring. One of these pajés was sent for by a woman in John Aracú's family, to. operate on a child who suffered much from pains in the head. Senhor John contrived to get possessiou of the supposed worm after the trick was performed in our presence, anil it turned out to be a long white air-ront of sonie plant. The paje was with difficulty persuaded to operate while Senhor John unil 1 were present. I cannot help thinking that he, as well as all others of the same profession, are conscious impostors, handing down the shallow secret of their divinutions and tricks from generation to generation. The institution seems to be common to all tribes of Indians, and to be held to more tenaciously than any other.

I bought of the Tushaúa two beautiful feather sceptres, with their bamboo cases. These are of cylindrical shape, about three feet in lenyth and three inches in diameter, and are made by gluing with wax the fine white and yellow feathers from the breast of the toucan on stout rods, the tops being ornamented with long plumes from the tails of parrots, trogons, and other birds. The Mun. durucús are considered to be the most expert workers in feathers of all the South American tribes. It is very difficult, however, to get them to part with the articles, as they seem to have a sort of superstitious regard for them. They manufacture head-dresses, sashes, and tunics, besides seeptres; the feathers being assorted with a good eye to the proper contrast of colors, and the quills worked into strong cotton webs woven with knitting sticks in the required shape. The-dresses are worn only during their festivals, which are celebrated, not at stated times, but whenever the $\mathrm{Tu}$ shafa thinks fit. Dancing, singing, sports, and drinking appear to be the sole objects of these occasional holidrys. When a day is fixed upon, the women prepare a great quantity of tarobá, and the monotonous jingle is: kept up, with little intermission, night unit day, until the stimulating beverage is tinished.

We left the Tushaúa's house early the next morning. The impression made upon me by the glimpse of Indian life in its natural state obtained here, and ut another cluster of houses visited higher up, was a pleasant one, notwithstanding the disagreeable ineident of the Parárauáte visit. The Indiaus ae he:e seen to the best advantage, having relinquished many of their must barbarous practices, without being corrupted by ton close contact with the inferior whites and halfbreeds of the civilized settlements. The manners are simpler, the demeanor more gentle, cheerful, and frank, thun among the Inlians who live near the towns. I could not help contrasting their well-fed condition, and tho signs of orderly, industrious habits, with the poverty and laziness of the semi-civilized ") vi)le of Altar de Chaó. I do not think that ine iutroduction of liquors has been the cause 
of much harm to the Brazilian Indian. $\mathrm{He}$ has his drinking bout now and then, like the common working people of other countries. It was his habit in his original state, before Europeans visited his country ; but he is always ashamed of it ufterward, and remains sober during the pretty long intervals. The harsh, slave-driving practices of the Portuguese and their descendants have been the greatest curses to the Indians ; the Mundurucús of the Cupari, however, have been now for many years protected against ill-treatment. This is one of the good services ren. dered by the missionaries, who take care that the Brazilian law in favor of the aborigines shall be respected by the brutal and unprincipled traders who go among them. I think no Indians could be in a happier position than these simple, peaceful, and friendly people on the banks of the Cupari. The members of each family live together, and seem to be much attached to each other; and the authority of the chief is exercised in the mild. est manner. Perpetual summer reigns uround them; the land is of the highest fertility, and a moderate amount of light work proAluces them all the necessuries of their simple Jife. It is difficult to get at their notions on subjects that require a little abstract thought; but the mind of the Indian is in a very primitive condition. I believe he thinks of nothing except the matters that immediately roncern bis daily material wants. There is an almost total absence of curiosity in his mental disposition, consequently he troubles himself very little concerning the causes of the natural phenomena around him. He has no idea of a Supreme Being; but, at the same time, he is free from revolting superstitions -his religious notions going no father than the belief in a evil spirit, regarded merely as a kind of hobgoblin, who is at the bottom of all his little failures, troubles in fishing, hunting, and so forth. With sv little mental activity and with feelings und passions slow of excitement, the life of these people is naturally monotonous and dull, and their virtues are, properly speaking, only negative; but the picture of hammless homely contentment they exhibit is very pleasing, compared with the state of savuge races in many ther parts of the world.

The men awoke me at four o'clock with th $e$ sound of their oars on leaving the port of the Tushaúa. I was surprised to find a dense fog veiling all surrounding objects, and the gir ouite cold. The lofty wall of forest, with the beautiful crowns of Assui palms standing jut from it on their slender, arching stems, looked dim and strange through the misty curtuin. The sudden change a little after sunrise had quite a magical effect ; for the mist rose up like the gauze veil before the transformation scene at a pantomime, and showed the glorious foliage in the bright glow of morning, glittering with dew-drops. Wt arrived at the falls about ten o'clcck. The siver here is nct more than forty yards broud, and falls over a low ledge of rock stretching

\section{in a nearly straight line across.}

We had now arrived at the end of the navi. gation for large vessels-a distance from the mouth of the river, according to a rough culculation, of a little over seventy miles. I found it the better course now to send Jesé and one of the men forward in the montaria with John Aracú, and remain myself with the cuberta and our other men, to collect in the neighboring for est. We stayed here four days ; one of the bcats returning each evening from the upper river with the produce of the day's chase of my huntsmen. I ob. tained six good specimens of the hyacinthine marcaw, besides a number of smaller birds, a species new to me of Guaríba, or howling monkey, and two large lizards. The Guarí. ba was an old male, with the hair much worn from his rump and breast, and his bedy disfigured with large tumors made by the grubs of a gad-fly (Astrus). The back and tail were of a ruddy-brown color; the limbs and under side of the body, black. The men as. ceniled to the second falls, which form a cataract several feet in height about fifteen miles beyond our anchorage. The macaws were found feeding in small flocks on fruit of the Tucumá palm (Astryocaryum Tucumá), the excessively hard nut of which is crusheã into pulp by the powerful beak of the bird. I found the craws of all the specimens filled with the sour paste to which the stone-like fruit had been reduced. Each bird tock me thrce hours to skin, and I was occupied with these and my other specimens every evening until midnight, after my own laborious day's hunt; working on the roof of my cabin by the light of a lamp.

The place where the cuberta was anchored formed a little rocky haven, with a sandy beach sloping to the forest, within which were the ruins of an Indian Maloca, and a large weed-grown plantation. The port swarmcd with fishes, whose movements it was amusing to watch in the deep, clear water. The must abundant were the Piı́nhas. One species, which raried in length, according to age, from two to six inches, but was recognizable by a black spot at the root of the tail, was always the quickest to seize any fragment of meat thrown into the water. When nothing was being given to them, a few only were seen scattered about, their heads all turned one way in an attitude of expectation; but as soon as any offal fell from the canoe the waier was liackened with the shoals that rushed instantaneously? to the spot. Thuse who did not succeed in securing a fragment fought with those who had been more successful, and many contrived ts steal the coreted morsels frum their mouths. When a bee or fly passed through the air near the water, they all simultaneously darted toward it as if ruused by an electric shock. Sometimes a larger fish approached. and then the hust of Piránhas took tle alarm and flashed out of sight. The population of the wa' er varied from day to day. Once a small shoal of a handsome black-banded fish.called by the natives Acará bundeira (Mesonauta 
insignis, of Gunther), came gliding through at a slow pace, forming a very pretty sight. At unother time. little troops of needle-fish, eellike animals with excessively long and slen. der-toothed jaws, suiled through the field, scattering before them the hosts of smaller fry ; and in the rear of the needle-fishes a strangcly-shaped kind called Sarapó came wriggling along, one by one, with a slow movement. We caught with hook and line, baited with pieces of bausna, several Curimatá (Anodus Amazonum) a most delicious fish, wrich, next to the Tucunare and the Pescuda, is most esteemed by the natives. The Curimata seemed to prefer the middle of the streum, where the waters were agitated beneath the little cascade.

The weather was now settled and dry, and the river sank rapidly - six inches iu twentyfour hours. In this remote and solitary spot I can say that I heard for the first and almost the only time the uproar of life at sunset, which Humboldt describes as having witnessed toward the sources of the Orinoco, but which is unknown on the banks of the larger rivers. The noises of animals began just as the sun sank behind the trees, after a swelterıng afternoon, leaving the sky above of the intensest shade of blue. Two tlocks of howling monkeys, one close to our canoe, the other about a furlong distaut, filled the echoing forest with their dismal roaring. Troops of parrots, including the hyacinthine macaw we were in search of, began then to pass over, the different styles of cawing and screaming of the various species making a terrible discord. Added to these noises were the sougs of strange Cicadas, one large kind perched high on the trees around our little haven setting up a most piercing chirp ; it began with the usual harsh jarring tone of its tribe, but this gradually and rapidly became shriller, until it ended in a long and loud note resembling the steam-whistle of a locomotive engine. Half a dozen of these wonderful performers made a considerable item in the evening concert. I had heard the same species before at Pará, but it was there very uncommou; we ubtained here one of them for my collection by a lucky blow with a stoue. The uproar of beasts, birds, and insects lasted but a short time : the sky quickly lost its intense hue, and the night set in. Then began the tree-frogs-quack-quack, drumdrum, hoo-hoo; these, accompanied by a melancholy night-jar, kept up their monotonous cries until very late.

My men encountered on the banks of the stream a Jaguar and a black Tiger, and were very much afraid of falling in with the Parárauátes, so that I could not, after their return on the fuurth day, induce them to undertake another journey. We began our descent of the river in the evening of the $26 \mathrm{th}$ of $\mathrm{Au}$ gust. At night forest and river were again enveloped in mist, and the air before sunrise was quite cold. There is a cunsiderable current from the falls to the house of John Aracú, and we accomplished the distance, with its aid and by rowing, in seventeen hours.

September 21st.-At five o'clock in the after. noon we emerged from the conflned and stifling gully through which the Cuparí flows, into the broad Tapajos, and breathed freely again. How I enjoyed the extensive view ufter being so long pent up : the mountainous: coasts, the gray distance, the dark waters. tossed by a refreshing breeze! Heat, mos. quitoes, insufficient and bad food, harl work and anxiety had brought me to a very low state of health; and I was now anxious to make all speed back to Santarem.

We touched at Aveyros, to embark some chests I had left there, and to settls accounts with Captain Antonio: finding nearly all the people sick with fever and vomit, against which the Padre's homœopathic giobules were of no avail. The Tapajos had been pretty free from epidemics for some years. past, although it was formerly a very unhealthy river. A sickly time appeared to be now returning ; in fact, the yeur following my visit (1853) was the most fatal one ever experienced in this part of the country. A kind of putrid fever broke out, which attacked people of all races alike. The uccounts we received at Santarem were most distressing : my Cuparí friends especially suffered very severely. John Aracú and his family all fell victims, with the exception of his wife: my kind friend Antonio Malagueita also died, and a great number of peciple in the Mundurucú village.

The descent of the Tapajos in the height of the dry season, which was now close at. hand, is very hazardous on account of the strong winds, absence of current, and shoaly water far away from the coasts. The river toward the end of september is about thirty feet shallower than in June; and in many places ledges of rock are laid bare, or covereil with only a small depth of water. I had betn warned of these circumstances by my Cupari friends, but did not form au aderuute idea of what we should hare to undergo. Canoes, in descending, only travel at night, when the terral, or light land breeze, blows off the eastern shore. In the daytime a. strung winl rages from down river, against which it is impossible to contend, as there is no current, and the swell raised by its sweeping over scores of miles of shallow water is dangerous to small vessels The coast for the greater part of the distance affords na shelter: there are, however, a number of little harbors, called esperas, which the canoe-men culculate upon, carefully arranging tach night voyage so as to reach one of them before the wind begins the next morning.

We left Aveyros in the evening of the 21st and sailed gently duwn with the soft landbreeze, keeping about a mile from the east. ern shore. It was a brilliant moonlit night, and the men worked cheerfully at the oars, when the wind was slack, the terral wafting from the furest a pleasant perfume like that of mignonette. At midnight wo made u fire and got a cup of coffee, and at three o'clock in the morning reached the sitio of Ricardo's 
lather, an Indian named André, where we anchored and slept.

September 22d.-Old André with his squaw came aboard this morning. They brought three Tracajás, a turtle, and a basketful of Tracají eggs, to exchange with me for cotton cloth and cashaça. Ricardo, who had been for some time very discontented, having now satisfied his longing to see his parents, cheerfully agreed to accompany me to Santarem. The luss of a man at this juncture would have been very annoying, with Captain Antonio ill at Aveyros, and nut a hand to be had anywhere in the neighborhood; but if we had not called at Audré's sitio we should not have been able to have kept Ricardo from running away at the first landing-place. He was a lively, restless lad, and although im. pudent and troublesome at first, had made a very good servant ; his companion, Alberto, was of quite a different disposition, being extremely taciturn, and going through all his duties with the quietest regularity.

We left at 11 A.M., and progressed a little before the wind began to. blow from down river, when we were obliged again to cast anchor. The terral began at six o'clock in the evening, and we sailed with it past the long line of rock-bound coast near Itapuáma. At ten o'clock a furious blast of wind came from a cleft between the hills, catching us with the sails close-hauled, and throwing the canoe nearly on its beam-ends, when we were about a mile frum the shore. Jose had the presence of mind to slacken the sheet 'of the mainsail, while I leaped forward and lowered the sprit of the foresail, the two Indiaus standing stupefied in the prow. It was what the canoe-men called a trovoada secca, or white squall. The river in a few minutes became a sheet of foam ; the wind ceased in about. half an hour, but the terral was over for the night, so we pulled toward the shore to find an anchoring place.

We reached Tapaiuna by midnight on the $23 \mathrm{~d}$, and on the morning of the 24th arrived at the Retiro, where we met a shrewd Santarem trader, whom I knew, Senhur Chico Honorio, who had a larger and much better provided canoe than our own. The wind was strong from beluw all day, so we remained at this place in his company. Ho had his wife with him, and a number of Indians, male and female. We slung our hammocks under the trees, and breakfasted and ined together, our cloth being spread on the andy leach in the shade, after killing a rargs quantity of fish with $t i m b \delta$, of which we had obtained a supply at Itapuáma. At night we were again under weigh with the land breeze. The water was shoaly to a great distance off the coast, and our canoe having the ilghter draught went ahead, our leadsman crying out the soundings to our companion : the depth was only one fathom, half a mile from the coast. We spent tho next day (25th) at the mouth of a creek called Pini, which is exactly opposite the village of Brim, and on the following night advanced about twelve miles. Everv point of land had long split of sand stretching one or two miles toward the middle of the river, which it was necessary to double by $a$ wide circuit. The terral failed us at midnight when we were near an espera, called Marai, the muuth of a shallow creek.

September 26th. - I did not like the prospect of spending the whole dreary day at Marai, where it was impossible to ramble ashore, the forest being utterly impervi.rus, and the land still partly under water. Besides, we had used up our last, stick of firewood to boil our coffee at sunrise, and could not get a fresh supply at this place. So there being a dead calm on the river in the morning, I gave orders at ten o'clock to move out of the harbor, and try with the oars to reach Paquiatúba, which was only five miles distant. We had doubled the shoaly point which stretches from the mouth of the creek, and were mak. ing way merrily across the bay, at the head of which was the port of the little settlement, when we beheld to our dismay, a few miles down the river, the signs of the violent day breeze coming down upon us - a long, rapidly advancing line of toam with the darkened water behind it. Our men strove in vain to gain the harbor: the wind overtook us, and we cast ancinor in three fathoms, with two miles of shoaly water between us and the land on our lee. It came with the force of a squall, the heavy billows washing over the vessel and drench. ing us with the spray. I did not expect that our anchor would hold; I gave out, how. ever, plenty of cable, and watched the result at the prow; José placing himself at the helm, and the men standing by the jib and foresail, so as to be ready if we dragged, to attempt the passage of the Maral spit, which was now almost dead to leeward. Our little bit of iron, however, held its place ; the bottom being fortunately not so sandy as in must other parts of the coast ; but uur weak cable then began to cause us anxiety. We remained in this position all day without food, for everything was tossing about in the hold; provision-cliests, baskets, kettles, and crockery. The breeze increased in strength toward the evening, wher the sun set fiery red behind the misty hills on the western shore, and the gloom of the siene was heightened by the strange contrasts of color, the inky water and the lurid gleam of the sky. Heavy seas beat now and then against the prow of our vessel with a fonce that made her shiver. If we had gone ashore in this race, all my precious collections would have been inevitably lust ; but we ourselves could have scrambled easily to land, and re-embarked with Senhor Honorio, who had remained behind in the Piní, and would pass in the course of two or three days. When night came, I lay down exhausted with watching and fatigue, and fell asleep, as my men had done some time before. About nine o'clock I was awoke by the montaria bumping against the sides of the vessel, which had veered suddenly round, and the full moon. -previously astern, then shone full in the 
cabin. The wind had abruptly ceased, giving place to light puffs from the eastern shre, and leaving a long swell rolling into the shoaly bay.

After this I resolved not to move a step be. youd Paquiatúba without an additional man, und une who understood the nuvigation of the river at this season. We reached the l:tuding place at ten o'clock, and anchored within the mouth of the creek. In the morning I walked through the beautiful shady alleys of the forest, whitch were water-paths in Juue when we touched here in ascending the river, to the house of Inspector Cypriano. After an infinite deal of trouble I succeeded i: persuading him to furnish me with another indian. There are about thirty families eslabished in this place, but the able-bodied men dad been nearly all drufted off within the last few weeks by the Government to accompany a military expedition against runaway negroes, settled in villages in the interior. Senhor Cypriano was a pleasant. lyoking und extremely civil young Mamelnco. He accompanied us, on the night of the $28 \mathrm{th}$, five miles down the river to Point Jaguarari, wisere the man lived whom he intended to send will me. I was glad to find my new Eand a steady, midale-aged and married In. diau ; his name was of very guod promise, Angelo Custodio (Guardian Angel).

Poiut Jaguarari forms at this season of the year a high sand-bank, which is prolongcd as a narrow spit, stretching about three miles $t$ oward the middle of the river. We rounded this with great difficulty in the night of the 29 th, reaching before daylight a grood shelter behind a similar sand-bank at Point Acarátingarí, a headland situated not more than five miles in a straight line from s,ur last anchoring place. We remained here all day: the men beating timbó in a quiet pool belind the sand-bank and the mainland, and olstining a great quantity of tish, from which I selected six species new to my col'ection. We made rather better progress the two following nights, but the terral now always blew strongly from the north-northeast after inidnight, and thus limited the hours during which we could navigate, forcing us to seek the nearest sheller to avoid being driven back faster thun we came.

On the 22d of October we reached Point Cajetúba, and had a pleasant day ashore. The river scenery in this neighborbund is of the greatest beauty. A few houses of set tlers ure seen at the bottom of the broad bay - of Aramána-i at the foot of a range of richly. timbered hills, the high beach of snow.white sand stretching in a bold curve from point to point. The opposite shores of the river are ten or eleven miles distant, but toward the north is a clear horizon of water and sky. Tae country near Point Cajetúba is similar to the neighborhood of Sanatarem : namely. campos with scattered trees. We gathered " large quantity of wild fruit : Cajú, Umiŕ, and Aápi: x́ng: The Umirí berry (Humi. rium tlo:ibuudum) is a black drupe similar in appeacauce to the Damascene olum and not greatly unlike it in taste. The Aápiráng is a bright vermilion-colored berry, with a hurd skin and a sweet viscid pulp inclosing the seeds. Betwen the point and Altar do Chao was a long stretch of sandy beach with moderately deep water; our men therefore took a rope ashore, and towed the cuberta at merry speed until we reached the village. A long, deeply-laden canoe with miners from the interior provinces here passed us. It was manned by ten Indians, who propelled the boat by poles, the men, five on each side, trotting one after the other along a plank arranged for the purpose from stem to stern.

It took us two nights to double Point Cururú, where, as already mentioned, the river bends from its northerly course beyund Altar do Chaõ. A confused pile of rocks, on which mauy a vessel heavily laden with farinha has been wrecked, extends at the scason of low water from the foot of a high bluff far into the stream. We were driven back on the first night (October 3d) by a squall. The light terral was carryingr us pleasautly round the spit, when as small black cloud which lay near tue rising monn sud. denly spread over the sky to the nortliward: the land breeze then ceused, and furious blasts began to blow across the river. We regained, with great difficulty, the shelter of the point. It blew alniost a hurricane for two hours, duriug the whole of wh ch time the sky over our heads was beautifully clear and starlit. Our shelter at first was nc $t$ very secure, for the wind blew away the lashings of our sails, and caused our anchor to drag. Angelo Custodio, however, seized a rope wbich was attachel to the foremast, and leaped ashore ; had he not done so we should probably have been driven miny miles back $\mathrm{k}$ ward up the storm-tossed river. After the cloud had passed, the regular east wind began to blow, and our further progress was effectually stopped for the night. The next day we all went ushore, ufter secusing well the canoe, anil slept from eleven v'clcck ti:! five, under the shade of trees.

The distance between Point Cururú and Santarem was accomplished in three days, aguinst the same difficulties of contrary and furious winds, shonly water, and rocky coasts. I was thunkful at length to be safely housed, with the whole of $\mathrm{my}$ collections, made under so many privatious and perils, landed withont the loss or damage of a specimen. The men, after unluading the canoe and delivering it to its owner, came to receive their payment. They took part in goods, and part in money, and after $r$ good supper. on the night of the 7th of October, shouldered their bundles and set off to walk by lund snme eighty miles to their homes. I was rather surprised at the good feeling exhibited by these pwor Indiuns at parting. Angelo Custodio said that whenever I shnuld wish to make another voyare up the Trpajos, he would be always realy to serve me as pilot. Alberto was undemonstrative as usual; hus Ricardo, with whum I hud had many sharp quarrels, actually shed lears when he shook hands and bid me the fival "arteos." 


\section{CHAPTER $\mathrm{X}$.}

THE UPPER AMAZONS-VOYAGE TO EAA.

Departure from Barra-First day and first night on the Upper Amazons-Desolate appearance of river in the flood season-Cucíma Indians-Mental condition of Indians - Squalls - Manatee - ForestFloatıng pumice-stones from the Andes-Falling banks-Ega and its inhabitants-Daily life of a naturallst at Ega-The four seasons of the Upper Amarons.

I MUST now take the reader from the picturesque, hilly country of the Tapajos, and its dark, streamless waters, to the boundless wooded plains and yellow turbid current of the Upper Amazons or Solimoens. I will resume the narrative of my first voyage up the river, which was interrupted at the Barla of the Rio Negro in the seventh chapter, to make way for the description of Santaiem und its neighborhood.

I embarked at Barru on the 26th of March, 1850 , three years before steamers were introduced on the upper river, in a cuberta which was returning to Ega, the first and only town of any importance in the vast solitudes of the Solimoens, from Santarem, whither it had been sent with a cargo of turtle-oil in earthenwure jurs. The owner, ar old white-haired Portuguese trader of Ega, named Daniel Cardozo, was then at Baira, attending the assizes as juryman, a public duly performed without remuneration, which took him six weeks away from his business. He was about to leave Barra himself, in a small boat, and recommended me to send forward my heavy baggage in the cuberta and make the journey with him. He would reach Ega, 370 miles distant from Barra, in twelve or fourteen days ! while the large vessel would be thirty or forty days on the road. I pieferred, however, to go in company with my luggage, looking forward to the many opportunities I should have of landing and making collections on the banks of the river.

I shipped the collections made between Pará and the Rio Negro in a large cutter which was about descending to the capital, and after a heavy days' work got all my chests aboard the Egu canoe by eight o'clock at night. The Indians were then all embarked, one of them being brought dead drunk by his companions and laid to sober himself all night on the wet boards of the tombadilha. The cabo, a spirited young white, named Estulano Alves Carnciro, who has since risen to be a distinguished citizen of the new province of the Upper Amazons, soon after gave orders to get up the anclıor. The men took to the oars, and in a few liours we crossed the broad mouth of the Rio Negro ; the night being clear, calm, and starlit, and the surface of the inky waters smooth us a lake.

When I awoke the next morning we were progressing by espia along the left bank of the Solimoens. The rainy season had now set in over the region through which the great river flows; the sund-banks and all ihe lower iands were already un ?er water, and the tearing current, two or three miles iv breadih, bore along a continuous line of up. rooted trees and islets of floating plants. The prospect was most melancholy; no sound was heard but the dull murmur of the. waters; the coast along which we traveled all duy was incumbered every step of the: way with fallen trees, some of which quiv.. ered in the currents which set around yrojecting points of land. Our old pest, the Motúca, began to torment us as suon as the: sun gained power in the morning. White: egrets were plentiful at the edge of the water, . and humming-birds, in some places, were: whirring about the flowers overhead. The: desolate appearauce of the lundscape ip. creased after sunset, when the moon rose $1 D$. mist.

This upper river, the Alto-Amazonas, or: Solimoens, is always spoken of by the Brazilians as a distinct stream. This is partly owing, as before remarked, to the direction it seems to take at the fork of the Rio Negro ; the inhabitants of the country, from their partial knowledge, not being able to compreliend the whole river system in one view. It has, however, many peculiarities to distinguish it from the lower course of the river. The trade wind, or sea breeze, which reaches, in the height of the dry season, as far as the mouth of the Rio Negro, 900 os 1000 miles from the Atlantic, never blows on the upper river. The atmosphere is therefore more stagnant and sultry, and the winds that do prevail are of irregular direction and short duration. A great part of the land on the borders of the Lower Amazons is hilly: there are extensive campos, or open plains, and long stretches of sandy soil clothed with thinner forests. The climate, in consequence, is comparatively dry, many months in succession during the fine season passing without rain. All this is changed on the Solimoens. A fortnight of clear sunuy reatlier is a rarity: the whole region through which the river and its affluents flow, after leaving the easternmost ridges of the Andes, which Pöppig describes as rising like a wall from the level country, 240 miles from the Pacific, is a vast plain, about 1000 miles in length, and 500 or 600 in breadth covered with owe uniform, lofty, impervious, and humid forest. The soil is nowhere sandy, but always either a stiff clay, alluvium, or vegetalibe mould. which latter, in many places, is sec $n$ in water-worn sections of the river banks $t$ 's be twenty or thirty feet in lepth. Will such a suil and climate, the luxuriancs of vegetation, and the abunclance and beauly c. $\hat{f}$ animal forms which are already s) great in. the regrion nearer the Atlantic, increase on the upper river. The fruits, both wild an.l cultivated, common to the two sections of the country, reach a progressively larger size in advancing west ward, and some trees whica blossom only once a year at Pará und Santarcm yield flower and fruit all the year raned at Ega. The climate is healihy, illough one lives here as in a permuneat. 
vapor bath. I must not, however, give here a loagthy description of the region, while we are yet on its threshold. I resided and traveled on the Solimoens altogether for four years and a half. The country on its borders is a magnificent wilderness where civilized man, as yet, has scurcely obtained a footing, the cultivated ground from the Rio Negro to the Andes amounting only to a few score acres. Man, indeed, in any condition, from his suall numbers, makes but an insignificant figure in these vast solitudes. It may be mentioned that the Solimoens is 2130 miles in length, if we reckon from the source of what is usually considered the main stream (Lake Lauricocha, near Lima); but 2500 miles hy the route of the Ucayali, the most rousiderable and practicable fork of the upper part of the river. It is navigable at all snasons by large steamers, for upward of 1400 miles from the mouth of the Rio Negro.

On the 28th we passed the mouth of Arianü, a narrow inlet which communicates with the Rio Negro, emerging iu frout of Barra. Our vessel was nearly drawn into this by the violent current which set from the Solimoens. The towing-cable was lashed to a strong tree about thirty yards ahead, and it took the whole strength of crew und passengers to pull across. We passed the Guariba, a second channel connecting the two rivers, on the $30 t h$, and on the 31 st sailed past a straggling settlement called Manacápurú, situated on a high rocky bank. Many citizens of Barra have sitios, or country-liouses, in this place, although it is eighty miles distant from the town by the nearest road. Beyond Manacápurú all traces of high land cease; both shores of the river, henceforward for many hundred iniles, are flat, except in places where the Tabatinga formation appears, in clayey elevatious of from twenty to forty feet above the line of highest water. The country is so completely destitute of rocky or gravelly beds that not a pebble is seeu during many weeks' juurney. Our voyage was now very monotonous. After leaving the last house at Manacápurú we travelled nineteen days without seeing a human habitation, the few settlers being located on the banks of inlets or lakes some - distance from the shores of the main river. We met only one vessel during.the whole of the time, and this did not come within hail, us it was drifting down in the middle of the current in a broad pait of the river, two miles from the bank along which we were laboriously warping our course upward.

After the first two ur three days we fell into a regular way of life aboard. Our crew was composed of ten Indians of the Cucáma luation, whose native cruntry is a portion of the borders of the upper river, in the neighborhoud of Nauta, in Peru. The Cucámas speak the Tupi language, using, however, a harsher accent than is common among the semi-civilized Indians from Ega dow uward. lhey are, a shrewd, hard-working people, and are the only Indians who willingly and in a body engage themselves to navigate the canoes of iraders. The pilot, a steady and faithful fellow named Vicente, told me that he and his companions hud now been fifteen months absent from their wives and families, and that on arriving at Ega they intended to take the first chance of a passage to Nauta. There was nothing in the appearance of these men to distinguish them from canoe-men in general. Some were tall and well built, others had squat figures with broad shoulders and excessively thick arms and legs. No two of them were at all similar in the shape of the head: Vicente had an oval visage, with fine regular features, while a little dumpy fellow, the way of the party, was quite a Mongolian in breadth and prominence of cheek, spread of nostrils, and obliquity of eyes; but these two formed the extremes as to face and figure. sone of them were tattooed or disfigured in any way; and they were all quite destitute of beard. The Cucáinas are notorious on the river for their provident habits. The desire of acquiring property is so rare a trait in Indians that the habits of these people ure remarked on with surprise by the Brazilians. The first posses. sion which they strive to acquire, on descending the river into Brazil, which all the Peruvian Indians look upon as a richer country than their own, is a wooden twieik with lock and key; in this tiey stow away carefully all their earnings converted into cluthing, hatchets, knives, harpoon heads, neelles and thread, and so forth. Their wages are only fourpence or sixpence a day. which is often paid in goods charged a hundred per cent above Paí prices, so that it takes them a long time tu fill their chest.

It would be difficult to find a better-behaved set of men ou a voyage than these poor Indians. During our thirty-five days' journey they lived and worked tugether in the most perfect good fellowship. I never heard au angry word pass among them. Senhor Estulano let them navigate the vessel in their own way, exerting his authority ouly now and then when they were inclined to be lazy. Vicente regulated the working bours. These depended on the darkness of the nights. In the first and second quarters of the moon they kept it up with espia, or oars, until toward midnight; in the third and fourth quarters they were allowed to go to sleep soon after sunset, aud aroused at threo or four o'cluck in the morning to resume their work. On cool, rainy days we all bore a hand at the espia, trotting with bare feet on the sloppy deck in Indian file, to the tune of some wild boutman's chorus. We had u favorable wind for two days only out of the thirty-five, by which we made about forty miles ; the rest of our long journey was uccomplished literally by pulling our way from tree to tree. When we encountered a remanso near the shoie, we got along very pleasantly for a few miles by rowing : but
this was a rare occurrence. During leisure 
Luurs the Indians employed themselves in sewing. Vicente was a good hand at cutting out shirts and trousers, and acted as master tailor to the whole party, each of whom had a thick steel thimble and a stock of needles and thread of his own. Vicente vade for me a set of blue-check cotton shirts uring the passage.

The goodness of these Indians, like that of most others among whom I lived, consisted jerhaps more in the absence of active bad qualities than in the possession of good ones; in other words, it was negative rather than positive. Their phlegmatic, apathetic emperament, coldness of desire and deadness if feeling, want of curiosity und slowness of intellect, make the Amazonian Indians very uninteresting companions anywhere. Their magination is of a dull, gloomy quality, and they seemed never to be stirred by the emotions-love, pity, admiration, fear, wonder, joy, enthusiasm. These are characteristics of the whole race. The good fellowship of our C'ucámas seemed to arise, not from warm sympatky, but simply from the absence of eager selfishness in small matters. On the morning when the favorable wind sprang up, one of the crew, a lad of about seventeen years of age was absent ashore at the time of starting, having gune aione in one of the montarius to gather wild fruit. TRe sails were spread, and we travelled for several bours at great speed, leaving the poor fellow vo paddle after us against the strong current. Vicente, who might have waited a few minutes at starting, and the otlers, only laughed when the hardship of their companion was alluded to. He overtouk us at night, having worked his way with frightful labnr the whole day without a morsel of food. He grinned when he came on board, and not a dozen words were said on either side.

Their want of curiosity is extreme. One day we had an unusually sharp thunder shower. The crew were lying about the deck, and after each explosion all set up a loud laugh ; the wag of the party exclaiming,

"There's my old uncle hunting again!" an expression showing the utter emptiness of mind of the spokesman. I asked Vicente what he thought was the cause of lightning und thunder. He said, "Timaá ichoqtiá," -I don't know. He had never given the subject a moment's thought! It was the same with other things. I asked him who made the sun, the stars, the trees ? He didn't know, and had never heard the suljject mentioned among his tribe. The Tup! language, at least as taight by the old Jesuits, has a word-Tupána-signifying God. Vicente sometimes used this word, but be showed by wis expressions that he did not attach the idea of a Creator to it. He seemed to think ic meant some deity, or visible image, which the whites worshipped in the churches he cad seen in the villages. None of the Indian iribes on the Upper Amazons have au idea cí a Supreme Being, and consequently have no word to express it in their own languages. Vicente thought the river on which we were 'travelling encircled the whole earth, and that the land was an island like those seen in the: stream, but larger. Here a gleam of curiosity and imagination in the Indian mind is: revealed: the necessity of a theory of the: earth and water has been felt, and a theory: has been suggested. In all other matters not? concerning the common wants of life the mind of Vicente was a blunk, und such I always found to be the case of the Indian in his natural state. Would a community of any race of men be otherwise, were they iso. lated for centuries in $a$ wilderness like tha. Amazonian Indians, associated in small num bers, wholly. occupied in procuring a mere: subsistence, and without a written language. or a leisured class to hand down acyuired. knowledge from generation to generation?

One day a smart squall gave us a good lift onward; it came with a cold, fine, driving rain, which enveloped the desulate landscape as with a mist : the forest $s$ wayed and roarer. with the force of the gale, and tlocks of ivirds. were driven about in alarm over the treetops. On another occasion a similar squa!l came from an unfavorable quarter : it fell upon us yuite unawares when we had all our salls out to dry, and blew us broadside foremust on the shore. The vessel was fairly lifted on to the tall bushes which lined the banks, but we sustained no injury beyond the entanglement of our rigging in the branches. The days and nights usually passed in a dead calm, or with light intermittent winds from up river, and consequently full against us. We landed twice a duy to give ourselves and the Indians a little rest aud change, and to cook our two meals-breakfast and dinner. There was unother passenger besides myself -a cautious middle-aged Portuguese, who was going to settle at Ega, where he had a brother long since established. He was accommodated in the fore-cabin or arched covering over the hold. I shares the cabin-proper with Senhoies Estulano anu Manuel, the latter a young half-caste, son-in-law to the owner of the vessel, under whose tuition I made good progress in leurning the Tupí language during the voyage.

Our men took it in turns, two at a time, to go out fishing, for which purpose we carried a spare munturia. The master had brought from Barra, as provisions, nothing but stale salt pirarecú -half-rotten fish, in large, thin, rusty slabs-furinha, coffee, and treacle. In these voyages passengers are expected to provide for themselves, as no charge is made except for freight of the heavy luggage or cargo they take with them. The Portuguese and myself had brought a few luxuries, such as beans, sugar, biscuits, tea, and so forth; but we found ourselves almost obliged to share them with our two companions und the pilot, so that before the royage was one third finished the small stock of most of these articles was exhausted. In return we shared in whatever the men brought. Sometimos they were quite unsuccessful, for fish is extremely difficult to procure in the season of high water, on account of the lower lands, lying. 
beinoen $t$. $e$ inlets and infinite chain of pools and lakes, being flouded from the main river, thus increasing tenfold the area over which the finny population has to range. On most days, huwever, they brought two or three fine fish, and once they harpooned a manatee, or Vacca marina. On this last-mentioned occusion we made quite a holiday ; the canoe was stopped for six or seven hours, and all turned out into the forest to help to skin and cook the animal. The meat was cut into cubical slabs, and each person skewered a dozen or so of these on a long stick. Fires were made, and the spits stuck in the ground and slanted over the flames to roust. A drizzling rain fell all the time, and the ground around the fires swarmed with stinging ants, attracted by the entrails and slime which were scattered about. The meat has somewhat the taste of very cuarse pork ; but the fat, which lies in thick layers between the lean parts, is of a greenish color, and of a disagreeable, fishy flavor. The animal was a large one, measuring nearly ten feet in leugth, and nine in girth at the broadest part The munatee is one of the few objects which excite the dull wonder and curiosity of the Indians, notwithstanding its commonness. The fact of its suckling its young at the breast, although an aquatic animal resembling a fish, seems to strike them as something very strange. The animal, as it lay on its back, with its broad ro:anded head and muzzle, taprring body, and smooth, thick, lead-colored skin, reminded me of those Egyptian tombs which are made of dark, smooth stone, and shaped to the human figure.

Notwithstanding the hard fare. the confinement of the cance, the trying weather, frequent and drenching rains, with gleans of fiery sunshine, and the woful desclation of the river scenery, I enjuyed the vsyage on the whole. We were not much troubled by mosquitoes, and therefore passed the nights very p'easantly, sleeping on deck, wrapped in blankcts or old sails. When the rains drove us below, we were less ccmfortable, as there was only just room in the small cabin for three of us to lie close together, and the confined air was stifling. I became inured to the Piums in the course of the first week; all the exposed parts of my body, by that time, being so clusely covered with black punctures that the little bloodsuckers could not very easily find an unoccupied place to operate upon. Poor Miguel, the Portuguese, suffered horribly from these pests, his ankles and wrists being so much influmed that ho was confined to his hammock, slung in the hold, fur weeks. At every landing place I had a rumble in the forest, while the redskins made the fire and cooked the meal. The result was a large daily addition to $\mathrm{my}$ collection of insects, reptiles, and shells. Sometimes the neighborhood of our gypsylike encampment was a tract of dry and spacious forest, pleasant to ramble in ; but more fiequently it was a rank - wilderness, into whicin it was impossible to penetrate many yards, on account of uprooted ices, entungled webs of monstrous woody climbers, thickets of spiny bamboos, swamps, or obstacles of one kind or other. The drier lands were sometimes beautified to the highest degree by groves of the Urucurí palm (Attalea excelsa), which grew by thousands under the crowns of the lofty ordinary forest trees; their smooth columnar stems being all of nearly equal height (forty or fifty feet), und their broad, finely-pinnuted leaves interlocking above to form arches und woven canopies of elegant and diversified slapes. The fruit of this palm ripens on the upper river in April, and during our voyage I saw immense quantities of it strewn about under the trees in places where we encamped. It is similar in size and shape to the date, and has a pleasantly-flavored juicy pulp. The Indians would not eat it ; I was surprised at this, as they greedily devoured many other kinds of palm fruit, whose sour and fibrous pulp was much less palatable. Vicente shook his head when he saw me one day eating a quautity of the Urucurí plums. I am not. sure they were not the cause of a severe indigestion under which I suffered fur manv da' s after. ward.

In passing slowly along the ir ${ }^{\circ}$ minable wooded bauks week after week, i observed that there were three tolerably distinct kinds of cuast and corresponding furest constantly recurring on this upper river. First, thero were the low and most recent alluvial deposits, a mixture of sand and mud, covered with tall, broad-leaved grasses, or with tho arrow-grass before described, whose featherytopped flower-stem rises to a height of fuurteen or fifteen feet. The only large trees which grow in these places are the Cecropia. Many of the smalier and newer islands were of this description. Secnndly, there were the moderately high banks, which are only partially overflowed when the flood seasun is at its height; these are wrodel with a magnificent varied forest, in which a great variety of palms and broad-leaved Maraniaceæ form a very large proportion of the veyeta. tion. The general foliags is of a vivid lightgreen hue; the water fruntage is soinetimes covered with a diversified mass if greenery ; but where the current sets strongly against the friable earthy banks, which at low water are twenty-five to thirty feet high, these are cut away, and expose a section of forest, where inc trunks of trees loaded witil epiphytes appear in massy colonnades. On might saiely say that thice fourths of the land bordering the Upper Amazous, for a thousand iniles, belong to this second cluss. The third description of coast is the higher. unduluting chiyey land which appears only "it lung intervals. but extends sometimes fır mauy miles along the borders of the river. The coust at these places is sloping, and composed of red or variegated clay. The fure't is of a different character frum that of th:c lower tracts: it is rounder in outline, mote uniform in its general aspect; palm.s are much less numerons and of peculiar speriis $\square^{*}$ destranire bulging-stemmed species, Iriar- 
tea ventricosa, and the slender glossy-leaved Bacába-1 (Énocarpus minor), being especially characteristic; and, in short, animal life, which imparts some cheerfulness to the other parts of the river, is seldom apparent. This "terra firme," as it is called, and a large portion of the fertile lower land, seemed well adapted for settlement; some parts were originally peopled by the aborigines, but these have long since become extinct or amalgamated with the white immigrants. I afterward learned that there were not more than eighteen or twenty families settled throughout the whole country from Manacápurú to Quary, a distance of 240 miles ; and these, as befure observed, do not live on the banks of the main stream, but on the shores of inlets and lakes.

The fishermen twice brought me small rounded pieces of very porous pumice-stone, which they had picked up floating on the surface of the main current of the river. They were to me objects of great curiosity, as being messengers from the distant volcanoes of the Andes: Cotopaxi, Llanganete, or Sungay, which rear their peaks among the rivulets that feed some of the early tributaries of the Amazons, such as the Macas, the Pastaza, and the Napo. The stones must have already travelled a distance of 1200 miles. I afterward found them rather com. mon; the Brazilians use them for cleaning rust from their guns, and firmly believe them to be solidified river foum. A friend once brought me, when I lived at Santarem, a large piece which had been found in the mid. dle of the stream below Monte Alegre, abuut 900 miles farther down the river; having reached this distance, pumice-stones would be pretty sure of being carriedout to sea, and flouted thence with the north-westerly Atluntic current to shores many thousand miles distant from the volcanoes which ejected them. They ure sometimes stranded on the banks in different parts of the river. Reflecting on this circumstance since I arrived in England, the probubility of these porous fragments serving as vehicles for the trans portation of seeds of plants, eggs of insects, spawn of fresh-water fish, and so forth, has suggested itself to me. Their rounded, -viter-worn appearance showed that they l.1ust have been rolled about for a long time in the shallow streums near the sources of the rivers at the feet of the volcanoes, before chey leaped the waterfulls and emburked on the currents which lead direct for the Ama$z$ ons. They may have been originally cast un the land aud afterward carried to the rivers by freshets; in which case the eggs und seeds of land insects and plants might be ccidentally introduced, and safely inclosed with particles of earth in their cavities. As tio speed of the current in the rainy season has been observed to be from three to five miles an hour, they might truvel an immense distance before the eggs or seeds were destroyed. I am ashamed to say that I neglectrd the opportunity, while on the spot, of ascertaining whether this was actually the case. The attention of naturalists has only lately been turned to the important subject of occasional means of wide dissemination of species of animals and plants. Unless such be shown to exist, it is impossible to solve sume of the most difficult problems connected with the distribution of plants and animals. Some species, with most limited powers of locomotion, are found in opposite parts of the earth, without existing in the intermedi. ate regions; unless it can be shown that these may have migrated or been accidentally trunsported from one point to the other, we shall have to come to the strange conclusion that the same species had been created in two separate districts.

Canoe-men on the Upper Amazons live in constant dread of the "terras chaidas," or landslips, which occasionally take place along the steep ear hy banks, especially when the waters are rısing. Large vessels are sometimes overwhelmed by these avalanches of earth and trees. I should have thought the accuunts of them exaggeruted if I had not had an opportunity during this voyage of seeing one on a large scale. One morning I was awoke before sunrise by an unusual sound resembling the roar of artillery. I was lying alone on the top of the cabin; it was very dark, and all my companious were asleep, so 1 lay listening. The sounds came from a considerable distance, und the crash which had aroused me was succeeded by others much less formidable. The first ex planation which occurred to me was that it was an earthquake ; for, although the night was breathlessly calm, the broad river was much agitated, and the vessel rolled heavily. Soon after, anuther loud explnsiun took place, apparently much nearer than the former one ; then followed others. The thundering peul rolled backward and forward, now seeming close at hand, now far off; the sudden crushes being often succeeded by a pause, or a long-continued dull rumbling. At the second explosion, Vicente, who lay snoring by the helm, awoke and told me it was a "terra cahida ;" but I could scarcely believe him. The day dawned after the uproar had lasted about an hour, and we then saw the work of destruction yoing forward on the uther side of the river, about three miles off. Large masses of forest, including trees of colossal size, probably 200 feet in height, were rocking to and fro, and falling headlong one after the other into the water. After each avalanche the wave which it caused returned on the crumbly bank with tremendous force, and caused the fall of other masses by under. mining them. The line of coast over which the landslip extended was a mile or two in length ; the end of it, huwever, was hid frum our view by an intervening island. It was a grand sight ; each downfall created a cluud of spray; the concussion in one place caus. ing other masses to give way a long distance from it, and thus the crashes continued, swaying tu and fro, with little prospect of a termination. When we glided out of sight 
two hours after sunrise, the destruction was still guing on.

On the 22d we threaded the Paraná-mirim of Aruuána-i, one of the numerous narrow by-waters which lie conveniently for canoes away from the main river, and often save a considerable circuit round a promontory or island. We rowed for half a mile through a magnificent bed of Victoria water-lilies, the flower-buds of which were just beginning to expand. Reyond the mouth of the Catua, a channel leading to one of the great lakes so numerous in the plains of the Amazons, which we passed on the 25th, the river appeared greatly increased in breadth. We travelled for three days along a broad reach, which both up and down river presented a blank horizon of water and sky : this clear view was owing to the absence of islunds, but it renewed one's impressions of the mugnitude of the stream, which here, 1200 miles from its mouth, showed so little diminution of width. Farther westward a series of large islands commences, which divides the river into two und sometimes three channels, each about a mile in breadth. We kept to the southernmost of these, travelling all day on the 30th of April along a high and rather sloping bank.

In the evening we arrived at a narrow opening, which would be taken, by a stranger naviguting the main channel, for the outlet of some insignificant stream: it was the mouth of the Teffé, on whose banks Ega is situated, the termination of our vuyage. After having struggled for thirty-five days with the muddy currents and insect pests of the Solimoens, it was unspeakably refreshing to find one' $\varepsilon$ self aguin in a durk-water river, smooth as a lake, and free from Pium and Motúca. The rounded outline, smali foliage, and sumbre-green of the woods, which seemed to rest on the glassy waters, made a pleasaut contrast to the tumultuous piles of rank, glaring, light-green vegetation, and torn, timber-strewn banks, to which we had been so long accustomed on the main river. The men rowed lazily until nightfall, when, huving done a laborious day's work, they discoutinued and went to sieep, intending to make for Ega in the mornng. It was not thought worth while to secure the vessel to the trees or cast ani:hor, as there was no current. I sat up for two or three hours after my companions had gone to rest, enjoying the solemn calm of the night. Not a breath of air stirred; the sky was of a deep blue, and the stars seemed to stand forth in sharp relief ; there was no sound of life in the woods, except the occasional melancholy note of some nocturnal bird. I reflected on my own wandering life : I had now reached the end of the third stage of my journey, and was now more than half way across the conti. nent. It was necessary for me, on many ac. counts, to find a rich locality for naturul history explorations, and settle myself in it for some mouths or years. Would the neigl. borhood of Ega turn out to be suitaivis and should I, a solitary stranger on a strange errand, find a welcume among its penple ?

Our Indians resumed their oars at sunrise the next morning (May 1st), and after an hour's rowing along the narrow channel, which varies in breadth from 100 to 500 yards, we doubled a low wooked point, and emerged sudulenly on the so-called Lake of Ega : a maynificent sheet of water, five miles broad-the expanded portion of the Teffé. It is quite clear of islands, and curves away to the west and south, so that its full extent is not visible from this side. To the left, on a gentle grassy slope at the point of junction of a broad tributary with the Teffe, lay the little settlement : a cluster of a hundred or so of palm-thatched cottages and whitewaslied red-tiled houses, each with its neatly. inclosed orchard of orange, lemon, banana, and guava trees. Groups of palms, with their tall slender shafts and feathery crowns, over. topped the buildings and lower trees. A. broad grass-carpeted street led from the narrow strip of white sundy beuch to the rudelybuilt barn-like church, with its wooden crucifix on the green before it, in the centre of the town. Cattle were grazing before the houses, and a number of dark-skinned natives were taking their morning bath among the canoes of various sizes which were anchored or moored to stakes in the port. We let off rockets and fired salutes, according to custom, in token of our safe arrival, and shortly afterward went ashore.

I made Ega my headquarters during the whole of the time I remained on the Upper Amasons (four years and a half). My excursions into the neighboring region extended sometimes as fur as 300 and 400 miles from the place. An account of these excursions will be given in subsequent chapters; in the intervals between them I led a quiet, uneventful life in the settlement; following my pursuit in the same peaceful, regular way us a naturalist might do in a European village. For many weeks in succession my journul records little more than the notes marle on my daily captures. I had a dry and spacious cottage, the principal room of which way made a workshop and study; bere a lai (ce table was placed, and my little library of reference arranged on shelves in rougl wooden boxes. Cages for drying specimena were suspended from the rafters by cords well anointed, to prevent ants from descending, with a bitter vegetable oil : rats and mice were kept from them by inverted cuyits, placed half way down the cords. I alwuys kept on hand a large portion of my privute collection, which contained a pair of ench species and variety, for the sake of compar. ing the old with the new acquisitions. My cottage was whitewushed inside and out about once a year by the proprietor, a native trader; the floor was of earth ; the ventiiation was perfect, for the outside air, und sometimes the rain as well, entered freely throingh gaps at the top of the walls under the cares, and through wide crevices in tho isorways. Rude as the dwelling was, I look 
back with pleasure on the many happy months I spent in it. I rose generally with the sun, when the grassy streets were wet with dew, and walked down to the river to bathe; five or six hours of every morning were spent in collecting in the forest, whose borders lay only five minutes' walk from my house ; the hot hours of the afternoon, between three and six o'clock, and the rainy days, were occupierl in preparing and ticketing the specimens, making notes, dissecting, and druwing. I frequently had short rambles by water in a small montaria, with an Indian lad to paddle. The neighborhood yielded me, up to the last day of my residence, an uninterrupted succession of new and different forms in the different classes of the animal kingdom, but especially insects.

There were, of course, many drawbacks to the umenities of the place as a residence for a Eurcpean; hut these were not of a nature that $\mathrm{my}$ readers would perhaps imugine. There was scarcely any danyer from wild animals : it seems almost ridiculous to refute the idea of danger from the natives, in a country where even incivility to an unoffending stranger is a rarity. A Juguar, however, paid us a visit one night. It was considered an extraordinary event, and so much uproar was made by the men who turned out with guns and bows and arrows that the animal scampered off and was heard of no more. Alligators were rather troublesome in the dry siason. During these months there was almost always one or two lying in wait near the bathing place for anything that might turn up at the edge of the water : dng, sheep. pig, child, or drunken Indian. When this visitor was about. every one took extra care while bathing. I used to imitate the natives in not advancing far from the bunk, and in keeping my eye fixed on that of the monster, which stares with a disgusting leer along the surface of the water; the body being submerged to the level of the eyes, and the top
of the head, with part of the dorsal crest, the of the head, with part of the dorsal crest, the was perceived in the water behind the rep. tive pentioned, of exploring in detail the whole quick retreat. I was never threatened my- Para, in the yeur 1851.

self, but I often saw the crowds of women During so long a residence I witnessed, and children scared while bathing, hy the of course, many changes iu the place. Some beast making a murement toward them; a of the good filends who made me welcome general scamper to the shore and peals of on my first arrival died, and I followed their linughter were always the result in these remains to their last resting-place in the lit(ases. The men can always destroy these tle rustic cemetery on the borders of the alligators when they like to take the trouble surrounding forest. I lived there long to set out with montarias and harpoons for enough, from first to last, to see the young the purpose; but they never do it unless one people grow up, attended their weddings, of the monsters, bolder than usual, puts some and the christenings of their children, and, one's life in dunger. This arouses them, and before I left, suw them old married folks they then track the enemy with the greatest with numerous families. In 1850 Ega was pertinacity; when half killed, they drag it only a village, dependent on Pará, 1400 ushore and dispateh it amid loud execra- miles distant, as the capital of the then un11ons. Another, however, is sure to appear divided province. In 1852, with the creation some days or weeks ufterward, and take the of the new pruvince of the Amazons, it bevacant place on the station. Besides alliga- carne a city; returned its members to the tors, the only animals to be feared are the provincial purliament at Barra ; had its aspoisonous serpents. These are certainly sizes, its resident judges, and rose to be the 
- chlef town of the comarca or county. A year :after this, namely, in 1853 , steumers werm in. troduced on the Solimoens; and from 1855 one ran regularly every two montlis between the Rio Negro and Nauta in Peru, touching at ali the villages, and accomplishing the distance in ascending, about 1200 miles, in cighteen days. The trade and population, however, did not increase with these (hanges. The people became more "civilized," that is, they began to dress according 1 ) the latest Parisian fashions, instead of y jing about in stockingless feet, wooden clogs, and shirt-sleeves; acquiled a taste for money-getting and office-holding; became divided into parties, and lost part of their former simplicity of manners. But the place remained, when I left in 1859 , pietty nearly what it was when I first arrived in 1850-a cemi-Indian village, with much in the ways :and notions of its people more like those of a small country towu in Northern Europe than a south American settlement. The place is healthy, and almost free from insect pests ; perpetual verdure surrounds it; the suil is of marvellous fertility, even for Brazil ; the endless rivers and labyrinths of chunnels iteem with fish and turtle; a tieet of steamers inight anchor at any season of the year in the lake, which has uninterrupted water com. munication straight to the Atlantic. What a future is in store for the sleepy little tropicul village !

After speaking of Ega as a city, it will have a ludicrous effect to mention that the cotal number of inhabitants is only about 1200 . It contains just 107 houses, about half of which are miserably built mud-walled cottages, thatched with palm-leaves. A fourth of the population are almost always -absent, trading or collecting produce on the sivers. The neighborhood within a radius of thirty miles, and including two other small villages, contains probably 2000 more people. - The settloment is one of the oldest in the country, having been founded in 1688 by Faher Sumuel Fritz, a Bohenian Jesuit, who induced several of tho ducile tribes of Indians, then scattered over the neighboring segion, to settle on the site. From 100 to 200 acres of sloping gruund around the place were afterward cleured of timber; but such is the encruaching vigor of vegetation in this - country that the site would quickly relapse into jungle if the inhubitanis neglected to pull up the young shoots as they arose. There is a striugent municipal law which - coinpels each resident $t_{\text {s }}$ weed a given space around his dwelling. Every mouth, wulle I - resided here, an inspector came round with , his wand of authority, and tined every one who had not complied with the regulation. "The Indians of the surrounding cuuntry have never been hostile to the European settlers. The rebels of Pará and the Lower Amazons, Iin 1835-6, did not succeed in rousing the natives of the Solimoens against the whites. -A party of forty of them uscencled the river for that purpose, but on arriving at Ega, insstead af meeting with sympultizess us in other places, they were surroundea by a small body of armed residents, and shot duwa without mercy. The military commandant at the time, who was the primu nuver in this orderly resistance to anarchy, was a courageous and lośal negro, numed 'Tosé Patricio, an officer knuwn throughout the Upper Amazons for his untlinciling honesty und love of ordur, whose acquantance I hud tho pleasure of making at St. Paulo in 1858. Ega was the healquarter's of the great scien. titic commission, which met in the years from 1781 to $1 \% 91$ to settle the boundaries between the Spanish and Portuguese territories in South America. The chief com. missioner for Spuiu, Don Francisco Requena, lived some time in the village with his family. I found only one person at Ega, my old friend Romaö de Oliveira, who recollected, or had any knowledge of this important time, when a numerous staff of astrono. mers, surveyors, and draughtsmen explored much of the surrounding country, with large bodies of suldiers and nutives.

Many of the Ega Indians, including all the domestic servants, are savages who have been brought from the neighboring rivers, the Japurá, the Issá, und the Solimoens. I saw here individuals of at least sixteen different tribes, most of whom had been bought, when children, of the native chiefs. This species of slave-dealing, although forbidden by the laws of Brazil, is winked at by the authorities, because without it there would be no means of obtaining servants. They all becume their own masters when they grow up, and never show the slightest inclination to return to utter savage life. But the boys generally run away and embark on the canves of traders; and the gurls are often badly treated by their mistresses, the jealous, passionate, and ill-educated Brazilian women. Nearly all the enmities which arise among residents at Ega and other places are caused by disputes about Indian servants. No one who has lived only in old settled countries, where service cun be readily bought, can imagine the difticulties aud annoyunces of a land where the servant class are iguorant of the value of money, and bands cannot be obtained except by coaxing them from the employ of other masters.

Great mortality takes place among the poor captive children on their arrival ut Ega. It is a siugular circumstance that the Indians residin's ou the Jupurí and other triby uries always fall ill on descending to the Solimoene, while the reverse takes place with the inhab. itants of the banks of the muin river, who never fuil of taking intermittent fever when they first ascend these branch rivers, and of getting well when they return. The tinest tribes of sarages who inhubit the country near Ega are the Juris aud Passés; these are now, however, nearly extinct, a few families only remaining on the banks of the retired creeks conuected with the Teffé, and on other liranch rivess between the Teffé and the Jutulí. They ure a peacerable. conthe and intusirious people, devided to ayrs. 
culture and fishing, and have always been friendly to the whites. I shall have occasion to speuk again of the Pussés, who are a slenderly-built and superior race of Indians,' distinguished by a large square tattooed patch in the middle of their faces. The principal cause of their decay in numbers seems to be a disease which always appears among them when a village is visited by people from the civilized settlements-a slow fever, accompanied by the symptoms of a common cold, "defluxo," us the Brazilians term it, ending probably in consumption. The disorder has been known to break out when the visitors were entirely free from it ; the simple con tact of civilized men, in some mysterious way, being sufficient to create it. It is generally fatal to the Jurís and Passés : the first question the poor patient Indians now put to an advancing canoe is, "Do you bring defluxo?"

My assistant, José, in the last year of our residence at Ega, "resgatou" (ransomed, the euphemism in use for purchased) two Indian children, a boy and a girl, through a Japurá trader. The boy was about twelve years of age, and of an unusually durk color of skin : he had, in fact, the tint of a Cafuzo, the offspring of Indian and negro. It wis thought he had belonged to some perfectly wild and houseless tribe, similar to the Parárauátes of the Tapajos, of which there are several in different parts of the interior of South America. His face was of regular oval shape, but his glistening black eyes had a wary, distrustful expression, like that of a wild animal; and his hands and feet were small and delicately formed. Soon after his arrival, finding that none of the Indian boys and girls in the houses of our neighbors un. derstood his language, he became sulky and reserved; not a word could be got fiom him until many weeks afterward, when he suddenly broke out with complete phrases of Portuguese. He was ill of swollen liver and spleen, the result of intermittent fever, for a long time after coming into our hands. We had found it difficult to cure him, owing to his almost invincible habit of eating earth, baked clay, pitch, wax, and other similar substances. Very many children on the upper parts of the Amazons have this strange habit; not only Indians, but negroes and whites. It is not, therefore, peculiar to the famous Otomacs of the Orinoco, described by Humboldt, or to Indians at all, und seems to originute in a morbid craving, the result of a meagre diet of tish, wild fruits, and mandioca meal. We gave our little savage the name of Sebastian. The use of these Indian children is to fill water-jars from the river, gather fire-wood in the forest, cook, assist in paddling the montariu in excursions, and so forth. Sebastian was often my companion in the woods, where he wus very useful in finding the smull birds I shot, which sometimes fell in the thickets among confused masses of fallen branches and dead leaves. He was wonderfully expert at catching lizards with his hands, and ut climbing. The smoothest stems of palm-trees offered little difficulty to him: he would gather a few lengths of tough flexible lianas, tie them in. a short endless band to support his feet $w i t h$, in embracing the slippery shaft, and then mount upward by a succession of slight. jerks. It was very amusing, during the tirstfew weeks, to witness the glee and pride with. which he would bring to me the bunches if fruit he had gathered from almost inaccessible trees. He avoided the company of burs: of his own race, and was evidently proud if being the servaut of a real white man. We brought him down with us to Pará: but he showed no emotion at any of the strang't sights of the capital : the steam vessels, large ships and houses, horses and carriages, tho pomp of church ceremonies, and so forth. In this he exhibited the usual dulness of feeling and poverty of thought of the Indian; he had, nevertheless, very keen perceptions, and. was quick at learning any mechanical art. José, who had resumed, some time before $\mathbf{l}$ left the country, his old trade of goldsmith, made him his apprentice, and he made very. rapid progress ; for after about three mouths' teaching be came to me one day with radiant. countenance, and showed me a gold ring of his own making.

The fate of the little yirl, who came with a second batch of children all ill of intermittent fever, a month or two after Sebastian. was very different. She was brought to our house, after landing, one night in the wet. season, when the rain was pouring in tor. rents, thin and haggard, drenched with wet, and shivering with ague. And old Indian who brought her to the door, said briefly, " ecui encommenda" (here's your little parcel, or order), und went away. Tidere was: very little of the savage in her appearance, and she was of a nuch lighter color than the boy. We found she was of the Mirunha. tribe, all of whom are distinguished by a slit, cut in the middle of each wing of the nuse, in which they wear on holiday occusions a large button made of pearly river sh ill. We took the greatest care of our little patient; had the best nurses in the town, fomentel rer daily, gave her quinine and the m'st. nourishing food; but it was ull of no avail ; she sank rapidly; her liver was enormously swollen, and almost as hard to the touch as. stone. There was something uncommonly pleasing in her ways, and quite unlike anything I had yet seen in Indians. Instead of. being dull and taciturn, she was always smiling and full of talk. We had an old woman of the same tribe to attend her, who explained what she said to us. She often begged to be taken to the river to bathe : asked for fruit, or coveted articles she saw in the room for playthings. Her native name was Oria. The last week or two she could not rise from the bed we had made for her in a lly corner of the room : when she wantell lifting, which was very often, she would allow no one tc help her but me, calling me by the naine of "Cariwa" (white man), the only word of Tupi she seemed to know. It was inexpressibly touching to hear her, us she lay, 
enad been tanght to recite with her companrons in her native village: a few sentences cepeuted over and over again with $x$ rhythmic accent, and relating to objects and incidents econnected with the wild life of her tribe. We hud her baptized before she died, aud when this latter event happened, in opposiution to the wishes of the big people of Ega. 1 insisted on buryiag her with the same honors as a child of the whites; that is, as an "anjinho" (little angel), according to the pretty Roman Cstholic custom of the country. We had the corpse clothed in a robe of fine calico, crossed her hands on her breast "over a "palma" of flowers, and made also a crown of flowers for her head. Scores of helpless children like our poor Oria die at Fga, or on the rnad; but generally not the slightest care is taken of them during their illness. They are the captizes made during the merciless ruids of one section of the $\mathrm{Mi}$ Ianha tribe on the territories of unother, and sold to the Ega traders. The villages of the :attacked hordes are surprised, and the nien and women killed or driven into the thickets without having time to save lheir children. There appears to be no doubt that the Miránhas are cunnibals, and therefore the purrhase of these captives probshly saves them ifrom a worse fate. The demand for them at Ega opcrates, however, us a direct cause of the supply, stimulating the unscrupulous chiefs, who receive all the profits, to undertake these murderous expeditions.

It is remarkable how quickly the savages of the various nations, which each have their $\omega \mathrm{kn}$, to all appearance, widely different lan-gnage, learn Tupí on their arrival at Ega, Where it is the common idiom. This perIhaps may be attributed chiefly to the gram matical forms of all the Indian tongues being the same, although the words are different. As far as I could learn, the feature is com. mon to all, of placing the preposition after the noun, making it, in faci, a post-position, thus : "He is come the village from ;" "Go him with, the plantation to," and so forth. The ideas to be expressed in their limited sphere of life and thought are few ; conse. quently the stock of words is extremely small; besides, all Indians have the same way of thinking, and the same objects to talk about ; these circumstances also contribute to the ease wilh which they leurn each other's lauguage. Hordes of the same tribe living on the same branch rivers, speak mutually unintelligible linguages; this happens with the Miránhas on the Japurá, and with the Collinas on the Jurúa ; while T'upí is spoken with little corruption aloug the banks of the muin Amazons for $u$ distance of 2500 miles. "The purity of Tupí is kept up by frequent communication among the natives, from one end to the other of the main river; how complete and long-continued must be the isolation in which the small groups of suvages have lived in other parts, to have caused so complete a segregation of dialects i It is probable that the strange inflexibility of the Indian organization, both bodily and mental is owing to the isolation in which each small tribe hus lived, and to the nurrow round of life and thought, and close intermarriages for countless generations, which are the necessary results. Their fecundity is of a low degree, for it is very rare to find an Indian family having so many as four children, and we have seen how great is their liability to sickness and death on removal from place to place.

I have already remarked on the different way in which the climate of this equatorial region affects Indians and negroes. No one could live long among the Indians of the Upper Amazons without being struck with their constitutional dislike to the heat. Europeans certainly withstand the high temperature better than the original inhrbitants of the country ; I always found I could myself bear exposure to the sun or unusualiy hot weather quite as well as the Indians, although not well fitted by nature fur a hot climate. Their skin is always hot to the touch, and they perspire little. No Indian resident of Ega can be induced to stay in the village (where the heat is felt more than in the forest or nil the river) for many days together. They bathe many times a day, but do not plunge in the water, taking merely a sitz-bath, as dogs may be seen doing in hot climutes, to cool the lower parts of the body. The women and children, who often remain at home, while the men are out for many days together tishing, generally find some excuse for troop. ing (Af to the shade of the forest in the hot hours of the afternoon. They are restless and discontented in fine dry weather, but cheerful in cool days, when the rain is pour ing down on their naked backs. When suffering under fever, nothing but strict watching can prevent them from going down to bathe in the river, or eating inmoderate quantities of juicy fruits, although these indulgences are frequently the cause of denth. They are very subject to disorders of the liver, dysentery, and other diseases of hot climates; and when any epidemic is about they fall ill quicker, and suffer more than negroes or even whites. How different all this is with the negro, the true child of tonpical climes! The inipression gradually forced itself on my inind that the red Indiun lives as a stranger or immigrant in these lot regions, and that his constitution was not uriginally adupted, and has not since become perfectly adapted, to the climute.

The Indian element is very prominent in the amusements of the Ega people. All the Roman Catholic holidays are kept up with great spir:t. rude Indian sports being mingled with the ceremonies introduced by the Portuguese. Besides these, the aborigines celebrate their own ruder festivals ; the people of different tribes combiuing; for, in most of their features, the merry-makings were originally alike in all the tribes. The Indian idea of a holiday is bontires, processions, masqueruding, especially the mimicry of different kinds of animuls, pleuty of confused diumming and fifing, monotoncus 
dancing, kept up hour after hour without in. termission; and, the most important point of all, getting gradually und completely drunk. But he attaches a kind of superstitious significance to these acts, and thinks that the amuserments appended to the Roman Catholic holidays, as celebrated by the descendants of the Portuguese, are also an essential part of the raligious ceremonies. But in this respect the uneducated whites and half-breeds gre not a bit more enlightened than the poor dull-souled Indiun. All look upon a religious holiday as an amusement, in which the priest takes the part of director or chief actor.

Almost every unusual event, independent of saints' days, is made the cccasion of a holiday by the sociable, easy-going people of the white and mameluco classes; funerals, christenings, weddings, the arrival of strangers, and so forth. The custom of "waking"' the dead is also kept up. A few days after I urrived I was awoke in the middle of a dark moist night by Cardozo, to sit up with a neighbor whose wife had just died. I found the body laid out on a table, with crucifix and lighted wax caudles at the head, and the room: full of women and gills squatted on stouls or on their haunches. The inen were seated round the open door, smoking, drinking coffee, and telling stories, the bereaved husband exerting himself much to keep the people merry during the remainder of the night. The Egu people seem to like an excuse for turning night into day ; it is so cool and pleasant, and they can sit about during these hours in the open air, clad as usual in simple shirt and trousers, without streaming with perspiration.

The patron saint is Santa. Theresa; the festival at whose anniversary lasts, like most of the others, ten days. It begins very quietly with evening litanies sung in the church, which are attended by the greater purt of the population, all clean and gayly dressed in calicoes and muslins; the girls wearing jasmines and other natural flowers in the hair, no other head-dress being worn by females of any class. The evenlngs puss - pleusantly; the church is lighted up with wax candles, and illuminated on the vutside by a great number of little oil lamps-rude clay cups, or halves of the thick rind of the bitter orange, which are fixed all over the front. The congregation seem very atten. tive, and the responses to the litany of Our Lady, sung by a couple of hundred fresh fernule voices, ring agreeably through the still village. Toward the end of the festival the fun commences. The managers of the feast keep open houses, and dancing, drumming, tinkling of wire guitars, and unbridled drinking by both sexes, old and young, are kept up for a couple of days and a night with little intermission. The ways of the people at these merry-makings, of which there are many in the course of the year, always struck me as being not very greatly different from thuse seen at an old-fashioned viilage wake in retired parts of Englund. The old frilks luok on and get very talkative over liseir cups ; the children are allowed a little extra. indulgence in sitting up; the dull, reseived fellows become loquacious, shake une another by the hand or slap each other on the bark, discovering, all at once, what capital friends: they are. The cantankerous individual gets quarrelsome, and the amorous unusua! $;$ i.wing. The Indian, ordinarily so tacitum, fiuds the use of his tongue, and gives the minu'test details of some little dispute which he had. with his master years ago, and which every one else had forgotten; just as: I huve known. lumpish laboring men in England do, when half-fuddled. One cunnot help reflecting. when witnessing these traits of manners, ou the similarity of human nuture everywhere, when classes are compared whose state of culture and cunditions of life are pretty nearly the sume.

The Indians play a conspicuous part in the amusements at St. John's eve, and at one or two other holidays which happen about that time of the year-the end of June. In some of the sports the Portuguese element is visible, in others the Indian; but it must be recollected that masquerading, recitative singing, and so forth are common originally to both peoples. A large number of men and boys disyuise themselves to represent differ. ent grotesque figures, animals, or peisons. Two or three dress themselves np as giants, with the help of a tall framework. One enacts the part of the Caypor, a kind of sylvau deity similar to the Curupíra which I luave before inentioned. The belief in this being seems to be common to all the tribes of the Tupi stock. According to the figure they dressed up at Ega, he is a bulky, misshapeu monster, with red skin und long shuggy red hair lianging half way down is back. They believe that he lias subterranean campos und hunting-grounds in the forest, well stucked with pacas and deer. He is not at all an (,b)ject of worship, nor of fear, except $\left.t_{1}\right)(\mathrm{h} !$ dren, being considered merely as a kind of hobgoblin.' Most of the maskers make themselves up as animals-bulls, deer, magoary, storks, jaguars, and so forth, with the ajd of light frameworks, covered with old cloth dyed or painted, and shaped according tu the object represented. Some of the imitutions which I saw were capital. One ingenious. fellow arranged an old piece of canvas in the form of a tapir, placed himself under it, and cruwled about on ald fours. He constructed au elastic nose to resemble that of the tapir, and made, before the doors of the principal residents, such a good imitation of the beast grazing, that peals of luughter greeted him wherever he went. Another man walked about solitarily, masked as a jabiı́ crane (a large animal standing about fuur feet high), and mimicked the gait and habits of the bird uncommonly well. One year un Indian lad imituted me, to the infinite amusernent of the townsfolk. He came the previo'ss day to borrow of me an old blouse and siraw hat. I. felt rather taken in when I saw him, on the night of the performance, ligged out as an entomologist, with an insect net, hunting- 
Jag, and pincushion. To make the imitation ccmplete, he had borrowed the frame of an old pair of spectacles, and went about with it straddled over his nose. The jaguar now and then made a raid among the crowd of boys who were dressed as deer, goats, and so furth. The maskers kept generally together, moving from house to house, and the per. formances were directed by an old musician, who sang the orders and explained to the spectators what was going forward in a kind of recitative, accompanying himself on a wire guitar. The mixture of Portuguese and Inuian customs is partly owing to the European immigrants in these parts having been uneducated men, who, instead of introducing European civilization, have descended almost to the level of the Indians, and adopted some of their practices. The performances take place in the evening, and occupy five or six hours; bonfires are lighted along the grussy streets, and the families of the better class are seated at their doors, enjoying the wild but good-humored fun.

We lived at Ega, during most part of the year, on turtle. The great fresh-water turtle of the Amazons grows on the upper river to an immense size, a full-grown one measuring nearly three feet in length by two in breadth, and is a lcad for the strongest Indiun. Every house has a little pond, called a curral (pen), in the back-yard to hold a stock of the ani mals through the season of dearth-the wet months; those who have a number of Indians in their employ send them out for a month when the waters are low to collect a stock, and those who have not, purchase their supply ; - with some difficulty, however, as they are rarely offered for sale. The price of turtles, like that of all other articles of food, has risen greatly with the introduction of steam vessels. When I arrived in 1850, a middle-sized one could be bought pretty readily for ninepence; but when I left in 1859 they were -with difficulty obtained at eight and nine shillings each. The abundance of turtles, or rather the facility with which thev can be found and caugh:, varies with the amount of annual subsidence of the wuters. When the river sinks less than the average, they are scarce; but when more, they can be caught in plenty, the bays and shallow lagoons in the forest having then only a small depth of $w$ ater. The tlesh is very tender, palatable, and wholesome; but it is very cloying ; every one ends, sooner or later, by becoming thoroughly surfeited. I became so sick of turtle in the course of two years that I could not bear the smell of it although at the same time nothing else was to be had, and I was suffering actual hunger. The native women cook it in various ways. The entrails are chopped up and made into a delicious soup called sarapatel, which is generally boiled in the concave upper shell of the animal used as a kcttle. The tender flesh of the breast is partially minced with farinha, and the breast shell then roasted over the fire, making a very pleasant dish. Steaks cut from the breast and cooked with the fat form another palatable dish. Largt sausages are made of the thick-coated stomach, which is filled with minced meat and boiled. The quarters cooked in a kettle of Tucupi source form another variety of food. When surfeited with turtle in all other shapes, pieces of the lean part roasted on a spit and moistened only with vinegar make an agreeable change. The smaller kind of turtle, the tracaja, which makes its appear. ance in the main river, and lays its egys a month earlier than the large species, is of less utility to the inhabitants, although its flesh is superior, on account of the difficulty of keeping it alive; it survives captivity but a very few days, although placed in the same ponds in which the large turtle keeps well for two or three years.

Those who cannot hunt and fish for themselves, and whose stomachs refuse turtle, are in a poor way at Ega. Fish, including many kinds of large and delicious salmonidæ, is abundant in the fine season ; but euch family fishes only for itself, and has no surplus for sale. An Indian fisherman remains out just long enough to draw what he thinks suff. cient for a couple of days' consumption. Vacca marina is a great resource in the wet seasun ; it is caught by harpooning, which requires much skill, or by strong nets made of very thick hammock twine, and placed across the narrow inlets. Very few Europeans are able to eat the meat of this animal. Although there is a large quantity of cattle in the neighborhood of the town, and pasture is abundant all the year round, beef can be had only when a beast is killed by accident. The must frequent cause of death is poisoning by drinking raw ucupi, the juice of the mandioca root. Bowls of this are placed on the ground in the sheds where the women prepare farinha; it is generally done carelessly, but sometimes intentionally, through spite, when stray oxen devastate the plantations of the poorer people. The juice is ulmost certain to be drunk if cattle stray near the place, and death is the certain result. The owners kill a beast which shows symptoms of having been poisoned, and retail the beef in the town. Although every one knows it cannot be wholesome, such is the scarcity of meat and the uncontrollable desire to eat beef, that it is eagerly bought, at least by those residents who come from other provinces where beef is the stuple article of food. Game of an kinds is scarce in the forest near the town, except in the months of June and July, when immense numbers of a large and handsome bird, Cuvier's toucan (Ramphastos Cuvieri) make their appearance. They come in well-fed condition, aud are shot in such quantities that every family has the strange treat of stewed and ronsted tou. cans daily for many weeks. Curassow birds are plentiful on the banks of the Solimuens, but to get a brace or two requires the sacrifice of several days for the trip. A tapir, of which the meat is most delicious and nourishing, is sometimes killed by a fortunate 
the pleasant effects which I once experienced from a dist of fresis tapir meat for a few days, after having been brought to a painful state of bodily and mental depressiun by a month's scanty rations of fish and farinha.

We sometimes had fresh bread at Ega, made from American flour brought from Pará, but it was sold at ninepence a pound. I was once two years without tasting wheaten bread, and attribute partly to this the gradual deterioration of health which I suffered on the Upper Amazons. Mandioca meal is a poor, weak substitute for bread; it is deficient in gluten, and consequently cannot be formed into a leavened mass or louf, but is obliged to be rousted in hard grains in order to keep any length of time. Cakes are made of the half-roasted meal, but they become sour in a very few hours. A superior kind of meal is manufactured at Ega of the sweet mandioca (Manihot Aypi); it is generally made with a mixture of the starch of the root, and is therefore a much more wholesome article of food than the ordinary sort which, on the Amuzons, is made of the pulp after the sturch has been extracted by soaking in water. When we could get neither bread nor biscuit, I fuund tanioca suaked in coffee the vest native substitute. We were seldom without butter, as every canoe brought one or two casks on each return voyage from Pará, where it is imported in considerable quantity from Liverpool. We obtained tea in the same way, it lueing served as a fashionable luxury at wedding and christening parties; the people were at first strangers to this article, for they used to stew it in a saucepan, mixing it up with coarse raw sugar, and stirring it with a spoon. Sometimes we had milk, but this was only when a cuw calved; the yield frum euch cow was very small, and lasted only for a few weeks in each case, although the pasture is good, and the animals are sleek and fat.

Fruit of the ordinary tropical sorts could generally be had. I was quite surprised at the variety of the wild kinds, and of the delicious flavor of some of them. Many of these are utteriy unknown in the regions nearer the Atlantic, being the peculiar productions of this highly favored, and little known, interior country. Sume have been planted hy the natives in their clearings. The best was the Jabuti-puihe, or tortoisefoot; a scaled fruit probably of the Anonaceous order. It is about the size of an ordinary apple; when ripe, the rind is moderately thin, and incloses. with the seeds, a quantity of custardy pulp of a very rich flavor. Next to this stands the Cumá (Collophora sp.) of which there are two species, not unlike, in appearance, small round pears; but the rind is rather hard, and contains a gummy milk, and the pulpy purt is almost as delicious as that of the Jabutí-pube The Cumá tree is of moderate heighr, and grows rather plentifully in the more elevated and drier situations A third kind is the Pamá. which is a stone fruit, similar in culor and appearance to the cherry, but of oblor. shape. The tree is one of the lointst in tne forest, and has never, I believe; been selected. for cultivation. To get at the fruit the vatives are obliged to climb to the height of about a hundred feet, and cut off the heavily laden branches. I have already mentioued the Umari and the Wishí; both these are now cultivated. The fatty, bitter pulp. which surrounds the large stony seeds of these fruits is eaten mixed with farinha, and is very zourishing. Another cultivated fruit. is the Purumá (Purumá cecropiæfolia, Martius), a round juicy herry, growing in large bunches and resembling grupes in taste. Another smaner kind, caiied Purumá-i, grows wild in the forest close to Ega, and has not yet been planted. The most singular of all these fruits is the Uiki, which is of oblong shape, und grows apparently crosswise on the end of its stalk. When ripe, the thick green rind opons by a natural cleft across the middle, und disclosest un oval seed : the size of a Damascene plum, but of $\alpha$ vivid crimson color. This bright hue belongs to a thin coating of pulp, which, when the seeds are mixed in a plate of stewed bananas, gives to the mess a pleasant rosy tint, and a rich creamy taste and consistence. Mingau (porridge) of bananas flavored and colored with Uiki is a favorite dish at Ega. The: fruit, like most of the others here mentioned, ripens in January. Many smaller fruits, such as Wajurú (probably a species. of Achras), the size of a gooseberry, which grows singly and cuntains a sweet gelatinous pulp, iaciosing two large shining black seeds ; Cashipári-arapaá, an oblong scarlet berry; two kinds of Bacuri, the Bacurísiúma and the B. curúa, sour fruits of a bright lemon colur when ripe, and a great number of others, are of less importance us articles of food.

The celebrated "Peach palm," Pupunha of the Tupí nations (Guilielma speciosa), is a common tree at Ega. The name, I suppose, is in allusion to the color of the fruit, and not to its flavor, for it is dry and mealy, and in taste may be compared to a mixture of chestnuts and cheese. Vultures devour it eagerly, and come in quarrelsome flocks to the trees when it is ripe. Dogs will ulso eat it : I do not recollect seeing cats do the same, although they go voluntarily to the woods to eat Tucumá, auother kind of palm fruit. The tree, as it grows in clusters beside the palm-thatched huts, is a noble ornament, being, when full grown, from fifty to sixty feet in height and often as straight as a scaffold-pole. A bunch of fruit when ripe is a load fur a strong mun, and each tree. bears several of them. The Pupunha grows wild nowhere on the Amazons. It is one of those few regetable productions (including three kinds of mandiuca and the American species of banaua) which the Indians have. cultivated from time immemorial, and brought with them in their original migration. to Brazil. It is nnly, however, the nore ad. ranced tribes who have hept up the cultiva. 
tion. The superiority of the fruit on the Solimoens to that grown on the Lower Amazons, and in the neighborbond of Pará, is very striking. At Ega it is generally as large as full-sized peach, and when boiled almost as mealy as a potato; while at Pará it is no bigger than a walnut, and the pulp is fibrous. Bunches of sterile or seedless fruits sometimes vccur in both districts. It is one of the principal articles of food at Ega when in season, and is boiled and eaten with treacle or salt. A dozen of the seedless fruits make a good nourishing meal for a grown-up person. It is the general belief that there is more nutriment in Pupunla than in fish or Vacca marina.

The seasons in the Cipper Amazons reyion offer some points of difference from those of the lower river and the district of Pará, which I wo sections of the country we have already scen also differ considerably. The year at Ega is divided according to the rises and falls of the river, with which coincide the wet and dry periods. All the principal transactions of life of the inhahitants are regulated by these yearly recurring phenomena. The peculiarity of this upper region consists in there being two rises and two fulls within the year. The great annual rise commences shout the end of February, and continues $t$. the middle of June, during which the rivers and lakes, confined duting the dry periods to their ordinary beds, gradually swell, and overflow all the lower lands. The iuundufion progresses gently, inch by inch, and is felt ererywhere, even in the interior of the forests, of the higher lands, miles away from the river: as these are traversed by numerous gullies, forming, in the fine seuson, dry spacious dells, which become gradually transformed by the pressure of the flood into broad creeks, navigable by small boats, under the shade of irees. All the countless swarms of turtle of various species then leuve the main river for the inland pools; sandbanks go under water, and the flocks of wading birds then migrate northerly to the upper waters of the tributaries which flow from that direction, or to the Orinoco; which streams during the wet period of the Amszons are enjoying the cluudless skies of their dry season. The families of fishermen who have been employed, during the previous four or five months, in harpooning and saltung pirarucú und shooting turtle in the great lakes, now return to the towns and villages, heir temporarily constructed fishing ( stal)ishments becoming gradually submerged, with the sand islets or beaches on which hey were situuted. This is the season, howver, in which the Brazil-nut and wild cacao ipen, and many persons go out to gather liese harvests, remaining ubsent generally hroughout the months of March and April. The rains during this time are not continuus ; they fall very heavily at times, but arely last su long at a stretch as twenty-four hours, and many days intervene of pleasant, unny weather. The sky, however, is genrally uvercast and glooun, and sometimes a

\section{drizzling rain falls.}

About the first week in June the flood is at its highest, the water heing then about forty-five feet rbove its lowest point ; but it vuries in different years to the extent of about fifteen feet. The "euchente," or flow, as it is called loy the natives, who believe this great annual muvement of the waters to be of the same nature as the tide toward the mouth of the Amazons, is then completed, and all begin to look forward to the "vasante," or ebb. The provision mude for the dearth of the wet season :s by this time pretty nearly exhuusted; fish is difficult to procure, and many of the less provident inhabitants have become reduced to a diet of fruits and farinha porridge.

The fine season begins with a few days of brilliant weather-furious hot sun, with passing clouds. Idle men and women, tired of the dulness and confinement of the flood season, begin to report on returning from their morning bath, the oessation of the flow : as agoas estao paradas, "the waters have stopped." The muddy streets, in a few days, dry up; groups of young fellows are now seen seated on the shady sides of the cottages, making arrows and knitting fishing-nets, with tucúm twine ; others are busy patching up and calking their canoes, large and small : in fact, preparations are made on all sides for the much longed-for "verao"" or summer, and the " migration," as it is called, of fish and turtle ; that is, their descent from the inuccessible pools in the forest to the main river. Toward the middle of July the sand-banks begin to reappear above the surface of the waters, and with this change come flocks of sandpipers and gulls, which latter make known the advent of the fine season, as the cuckoo does of the European spring, utteriag almust incessuntly their plaintive cries as they fly about over the shallow waters of sandy shores. Most of the gayly-plumaged birds have now finished moulting, and begin to be mose active :n the forest.

The fall continues to the micldle of ve' 0 ber, with the inter ruption of a purtial riss called "repiquet," of a few iuches in the midst of very dry weather in September, caused by the swollen contribution or some lasge afflu ent higher up the river. The amount of sub. sidence also valies considerably, but it is never so great as to interrupt navigation by large vessels. The greater it is the more abundant is the season. Every one is pros. perous when the waters are low, the shallow bays and pools being then crowiled with the coucentrated population of fish and turtle. All the people, men, women, and children, leave the villages, and spend the few weeks of glorious weather rambling over the vast undulating expanses of sund in the middle of the Solimoens, fishing, huuting, collecting eggs of turtle and plovers, and thoroughly enjoying themselves. The inhabitants pray always for a " vasante grande," or great cbb.

From the middle of October to the begin. ning of January the second wet season pre- 
vails. The rise is sometimes not more than ubout fifteen feet, but it is, in some years, much more extensive, laying the large sand islands under water before the turtle-eggs are hatched: In one year, while I resided at Ega, this second annual inundation reached to within ten feet of the highest water point, as marked by the stains on the trunks of trees by the river side.

The second dry season comes on in January, and lasts throughout February. The river sinks sometimes to the extent of a few feet only, but one year (1856) I saw it ebb to witbin ubout five feet of its lowest point in Septemher. This is called the sunimer of the Umarí, "Verao do Umarí," after the fruit of this name already described, which ripens at this season. When the fall is great, this is the best time to catch turtles. In the year above mentioned, nearly all the residents who had a canoe, and could work a paddle, went out after them in the month of February, and about 2000 were caught in the course of a few days. It appears that they hud been arrested, in their migration toward the interior pools of the forest, by the sudden drying up of the water-courses, and so had become easy prey.

Thus the Ega year is divided into four seasons, two of dry weatler and falling waters, and two of the reverse. Besides this variety, there is, in the month of May, a short seasun of very cold weather, a most surprising circumstance in this otherwise uniformly sweltering climate. This is cuused by the continuance of a cold wind, which blows from the south over the humid forests that extend, without interruption, from north of tine equator to the eighteenth parallel of latitude in Bolivia. I had, unfortunately, no thermometer with me at Eya, the criy one I brought with me from England having been lost at Pará. The temperature is so much lowered that fishes die in the river Teffé, and are cast in considerable quantities on its shores. The wind is not strong; but it brings cloudy weather, and lasts from three to five or six days in each year. The inhabitants all suffer much from the cold, many of them wrapping themselves up with the warmest clothing they can get (blankets are here unknown), and shutting themselves indoors with a charcoal fire lighted. I found, myself, the change of temperature most delightful, and did not require extra clothing. It was a bad time, however, for my pursuit, as birds and insects all betook themselves to places of concealment, and remained inactive. The neriod during which this wind prevails is called the "tempo da friagem," or the seison of colduess. The phenumena, I presume, is to be accolinted for by the fact thit in May it is winter in the southern temperate zone, and that the cool currents of air travelling thence northwurd toward the equator, become oniy moderately heated iu their course, owing to the intermediate country being a vast partially-flouded plain covered with humid forests.

\section{CHAPEER XI.}

\section{EXCURSIONS IN THE NEIGHBORHOOD OF EGA}

The River Teffé-Rambles through groves on the beach-Excursion to the house of arPasé chieftair - Character and customs of the Passé tribe-First: excursion to the sand inlands of the SolimoensHabits of great river-turtle-Second excursion Turtle-fishing in the island pools-Tnird excursion. -Hunting rambles with natives in the forest-Re. turil to Ega.

I WILL now proceed to give some accounts, of the more interesting of Issy shorter excur sions in the neighborhoud of Ega. The in. cidents of the longer voyages; which occupied each several nonths, will be narrated in a separaie chapter.

The settlement, as beforedescribed, is built on a small tract of cleared land at tne lower or eastern end of the lake, six or seven miles. from the main Amazons, with which the lake communicates by a nurrow channel. Ou the. opposite shore of the hroad expanse stands a small village, called Nogueira, the houses of which are not visible from Ega, except on very clear days ; the coast on the Nogueira. side is high, and stretches away inte the gray distance toward the soutb-west. The upper part of the river Tetis is not visited by tho. Ega people, on account of its: extreme un. healthiness, and its burrenness iu salsuparilla. and other wares. To Europeans it would. seem a most surprising thing that the peuple of a civilized settlement, 170 years old, should still be ignorant of the course of theriver on whose banks their native place, for which they proudly claim the title of city, is situated. It would be very difficult for a private individual to explore it, as the neces. sary number of Indian paddlers could not bo ubtained. I knew only one person who had ascended the T'efte to any considerable distance, and he was not able to yive ma a distinct account of the river. The only tribeknown to live on its banks are the Catauisnis, a people who perforate their lips all round, and wear rows of slender sticks in the holes: their territory lles between the.Purús and the Juruá, embracing both shores of the Teffé. A large navigable stream, the Bararuá, enters. the lake from the west, about thirty miles above Ega; the breadth of the lake is much contracted a little below the mouth of tins. tributary, but it again expands further sonth, and terminates abruptly where the Teffé. proper, a narrow river with a strong curreut, forms its head water.

The whole of the country for hundreds of miles is covered with picturesque but pathless: forests, and there are only two roads along which excursions can be made by land from. Ega. One is a narrow hunter's truck, about two miles in length, which traverses the forest in the rear of the settlement. The otheris an extremely pleasant path along the beach. to the west of the town. This is practicable only in the dry season, when a flat stıip of white sandy beach is exposed at the foot of the high wooded banks of the lake, covered. with irees, which, as there is no underwood.. 
turu a spaclous shady grove. I rambled daily, during many weeks of each successive dry season, along this delightful road. The trees, may of which are myrtles and wild guavas, with smooth yellow stems, were in Hower at this time; and the rippling waters of the lake, under the cool shade, everywhere bordered the path. The place was the resort of kingfishers, green and blue tree-creepers, purple-headed tanagers, and humming-birds. Birds generally, however, were not numerous. Every tree was tenanted by Cicadas, the reedy notes of which produced that loud jarring insect music which is the general ac. companiment of a woodland ramble in a hot climate. One species was very handsome, having wings adorned with patches of bright green and scarlet. It was very common, sometimes three or four tenanting a single tree, clinging as usual to the brunches. On approaching a tree thus peopled, a number of little jets of a clear liquid would be seen squirted from aloft. I have often received the well-directed discharge full on my face; but the liquid is harmless, having a sweetish taste, and is ejected by the insect from the anus, probably in self-defence, or from fear. The number and variety of gayly tinted butterflies, sporting about in this grove on sunny days, were so great that the bright moving flakes of color gave quite a character to the physiognomy of the place. It was impossible to walk far without disturbing flocks of them from the dump sand at the edge of the water, where they congregated to imbibe the moisture. They were of almost all colors, sizes, and shapes : 1 noticed here altogether eighty species, belonging to twenty-two different genera. It is a singular fact that, with very few exceptions, all the individuals of these various species thus sporting in sunny places were of the male sex; their partners, which are much more soberly dressed and immensely less numerous than the males, being coufined to the shades of the woods. Every afternoon, as the sun was getting low, I used to notice these gaudy sunshine-loving swains trooping off to the forest, where I suppose they would find their sweethearts and wives. The most abundant, next to the very common sulphur-yellow and orange-colored kinds, were about a dozen species of Eunica, wbich are of large size, and are conspicuous from their liveries of glossy dar'k blue and purple. A superbly. adorned creature, the Callithea Markii, hav. ing wings of a thick texture, colured sapphire-blue and orange, was only an occar sional visitor. On certain days, when the weather was very calm, two small gilded green species (Symmachia Trochilus and Colubris) literally swarmed on the sands, their glittering wings lying wide open on the flat surface. The beach terminates, eight miles beyond Ega, at the mouth of a rivulet; the character of the coast then changes, the river banks being masked by a line of low islets amid a labyrinth of channels.

In all other directions my very numerous excursions were by water; the most interest- ing of those made in the immediate neighhorhood were to the houses of Indians on the banks of retired creeks; an account of one of these trips will suffice.

On the $23 \mathrm{~d}$ of May, 1850, I visited, in company with Antonio Cardozo, the Delegado, a family of the Passe tribe, who live near the head waters of the Igarapé, which flows from the south into the Teffe, entering it at Ega. The creek is more than a quatter it a mile bruad near the town, but a few mili ; inland it gradually contracts, until it becomes a mere rivulet flowing through a broad deil in the forest. When the river rises, it fills this dell; the trunks of the lofty trees then stand many feet deep in the water, and small canoes are able to travel the distance of a day's journey under the shade, regular patl: 3 or alleys being cut through the hranches an? lower trees. This is the general character of the country of the Upper Amazons; a land of small elevation and abruptly undulated, the hollows forming narrow valleys in the dry months, and deep navigable creeks in the wet months. In retired nooks on the margins of these shady rivulets, a few families or small hordes of aborigines still linger in nearly their primitive state, the relics of their once numerous tribes. The family we in. tended to visit on this trip was that of Pedrouassú (Peter the Great, or tall Peter), an old chieftain or Tushaúa of the Passés.

We set out at sunrise, in a small igarite, manned by six young Indian paddlers. After travelling about three miles along the broad portion of the creek-which, being surrounded by woods, had the appearance of a large pool-we came to a part where our course seemed to be stopped by un impenetrable hedge of trees and bushes. We were some time before finding the entrance, but when fairly within the shades, a remarkable scene presented itself. It was my first introduction to these singular water-paths. A narrow and tolerably straight alley stretched away for a long distance before us : on each side were the tops of bushes and young trees, forming a kind of border to the path, und tle trunks of the tall forest trees rose at irregulir intervals from the water, their crowns interlocking far over our heads, and forming a thick shade. Slender air roots hung down in clusters, and looping sipós dangled from the lower brinches ; bunches of grass, tillunctsiæ, and ferns, sat in the forks of the larger houghs, and the trunks of trees near the watcr had adhering to them round dried masses of fresh-water sponges. There was no current perceptible, and the water was stained of a dark olive-brown hue, but the submerged stems could be seen through it to a great depth. We travelled at good speed for three hours along this shady road, the distance of Pedro's house from Egra being about twenty miles. When the paddlers rested for a time, the stillness and gloom of the place becunie almost painful : our voices waked dull echocs as we conversed, aud the noise made by fishes occasionally whipping the surface of t?:e water was quite sturtling. A cool, moist, 
clammy air pervaded the sunless shade.

The breadth of the wouded valley, at the commencement, is probably more than half a mile, and there is a tolerably clear view for a considerable distance on each side of the water-path through the irregular colonnade of trees : other paths aiso, in this part, branch off right and left from the principal road, leading to the scattered houses of Indians on the inainland. The dell contracts gradually toward the head of the rivulet, and the forest then becomes denser; the water-path also diminishes in width, and becomes more winding on account of the closer growth of the trees. The boughs of some are stretched forth at no great height over one's head, and are seen to be loaded with epiphytes; one rorchid I noticed purticularly, on account of its bright yellow flowers growing at the end of fluwer-stems several foet long. Some of the trunks, especially those of palms, close beneath their crowns, were clothed with a thick mass of glossy shield-shaped Pothos plants, mingled with ferns. Arrived at this part, we were, in fact, in the heart of the virgin forest. We heard no noises of animals in the trees, and saw only one bird, the sky-blue chatterer, sitting alone on a high branch. For some distance the lower vegetation was so dense that the road runs under an arcade of foliage, the branches having been cut away only sufficiently to admit of the passage of a small canoe. These thickets are furmed chiefly of bamboos, whose slender foliage and curving stems arrange themsolves in elegant feathery bowers ; but other social plants, slender green climbers with tendrils so eager in aspiring to grasp the higher bougbs that they seem to be endowed almost with animal energy, and certain low trees having large elegantly-veined leaves, contribute also to the juugly masses. Occasionally we came upon an urrooted tree lying across the path, its voluminous crown still held by thick cables of sipo, connecting it with standing trees: a wide circuit had to be made in these cases, and it was sometinies difficult to find the right path again.

At length we arrived at our journey's end. We were then in a very dense and gloomy part of the forest : we could see, however, the dry land on both sides of the creek, and to our right a small sunny opening appeared, the landing-place to the native dwellings. The water was deep close to the bauk, and a clean pathway ascended from the shady port to the buildings, which were about a furlong distant. My friend Cardozo vas gudfather to a grandchild of Pedro-uassu, whose daughter had married an Indiun settled in Ega. He had sent word to the old man that he intended to visit him : we were therefore expected.

As we landed, Pedro-uassú himself came down to the port to receive us, our arrival having been announced by the barking of dogs. He wus a tall and thin old man, with a serious but benignant expression of cuinntenance, and a manner much freer from shyness and distrust than is usual with Indians.
He was clad in a shirt of coarse cotton cloth, dyed with murishi, and trousers of the same material turned up to the knee. His features were sharply delineated-more so than in any Indian face I had yet seen; the lips thin and the nose rather high and compressed. A large, square, blue-black tattooed patch occupied the middle of his face, which, as well as the other exposed parts of his body, was of a light reddish-tan colur, instead of the usual coppery-brown hue. He walked with an upright, sluw gait, and on reaching us saluted Cardozo with the air of a man who wished it to be understood that he was dealing with an equal. My friend introduced me, and I was welcomed in the same grave, ceremonious manner. He seemed to have many questions to ask; but they were chiefly about Senhora Felippa, Cardozo's Indian housekeeper at Ega, and were purely compliment. ary. This studied politeness is quite natural to Indians of the advanced agricultural tribes. The language used was Tupí : I heard no other spoken all the day. It must te borne in mind that Pedro-uassú had never had much intercourse with whites : he was, although baptized, a nrimitive Indian, who had always lived in retirement, the ceremony of baptism having been gove through, as it generally is by the aborigines, simply from a wish to stand well with the whites.

Arrived at the house, we were welcomed by Peäru's wife, a thin, wrinkled, active old squaw, tattuned in precisely the same way as her husband. She had also sharp features, but her manner was more cordial and quicker than that of her husband; she talked much and with great inflection of voice, while the tones of the old man were rather drawling and querulous. Her clothing was a long petticoat of thick cotton cluth, and a very short chemise, not reaching to her waist. I was rather surprised to find the grounds around the establishment in neater order than in any sitiv, even of civilized people, I had yet seen on the Upper Amazons : the stock of utensils and household goods of all sorts was larger, and the evidences of regular industry and plenty more numerous than one usually perceives in the farms of civilized Indians and whites. The buildings were of the same construction as those of the humbler sottlers in all other parts of the country. The family lived in a large, oblong, open shed built under the shade of trees. Two smaller buildings, detached from the shed and having mud walls with low doorways, contained apparently the sleeping apartments of different members of the large household. A small mill for grinding sugar-cane, having two cylinders of hard notched wood; wooden troughs, and kettles for boiling the guarapa (cane juice), to make treacle, stood under a separate shed, and near it was a large inclosed mud-house for poultry. There was another hut and shed a short distance off, in. habited by a family depeudent on Pedro, and a narrow pathway through the luxuriant wisuds led $t$ ) more dwellings of the sams kind. There was an abundance of fruit-trees 
sround the place, including the never-failing banana, with its long, broad, soft green leafblades, and groups of full-grown I'upúnhas, or peach palms. There was also a large number of cotton and coffee trees. Among the utensils I noticed baskets of different shapes, made of flattened maranta stalks, und dyed various colors. The making of these is an original art of the Passés, but I believe it is also practised by other tribes, for I saw several in the houses of semi-civilized Indiaus on the Tapajos.

There were only three persons in the house besides the old couple, the rest of the peopla being absent; several came in, how ever, in the course of the day. One was a daughter of Pedro's, who had an oval tattooed spot over her mouth; the second was a young grandson, and the third the son-inlaw from Ega, Curdozo's compaảre. The old woman was occupied, when we entered, in distilling spirits from curá, an eatable root similar to the potuto, by means of a clay still, which had been manufactured by herself. 'The liquor had a reddish tint, but not a very agreeable flavor. A cup of it, warm from the still, howevier, was welcome after our long journey. Cardozo liked it, emptied his cup, and replenished it in a very short time. The old lady was very talkative, and almost fussy in her desire to please her visitors. We sat in tucúm hammocks, suspended between the upright posts of the shed. The young woman with the blue wouth-who, ulthough married, was as shy as any young maiden of her race-soon became employed in scalding and plucking fowls for the dinner, near the fire on the ground at the other end of the dwelling. The son-in-law, Pedro-uassú, and Cardozo now began a long conversation on the subject of their deceased wife, daughter, and comadre.* It appeared she had died of consumption- "tisica," as they called it, a word adopted by the Indians from the Portuguese. The widower repeated over and over again, in neurly the same words, his account of her iłness, Pedro chiming in like a chorus, and Cardozo moralizing and condoling. I thought the cauim (grog) had a good deal to do with the flow of talk and warmth of feeling of all three: the widower drank and wailed until he became maundering, and finally fell asleep.

I left them talking, and went a long ramble into the forest, Pedro sending his grandsun, a smiling, well-behaved lad of about fourteen yeurs of agc, tc show me the paths, my compunion taking with him his Zarabatana, or blow-gun. This instrument is used by all the Indian tribes on the Upper Amazons. It is gewerally nine or ten feet long, and is made of two separate lengths of woud, each scouped out so as tn form one half of the tube. To do this with the necessary accuracy requires an enormous amount of patient labor, and considerable mechanical

- Co-mother ; the term expressing the relationship of a mother to the godfather of her child. ability, the tools used being simply the incsior teeth of the Páca and Cutia. The tw hulf tubes when finished are secured together by a very close and tight spirally-wound strapping, consisting of luug flat strips of J acitára, or the wood of the climbing palm-tree ; and the whole is sineared afterward with black wax, the production of a Melipona bee. The pipe tupers toward the muzzle, and a cup-shaped mouth-piece made of wool. is fitted in the broad end. A full sized $Z$ al'a. batana is heary, and can only be used by an adult Indian who has had great praciice. The young lads learn to shoot with smalier und lighter tubes. When Mr. Wallace aw $I$ had lessons at Barra in the use of the bluwgun, of Julio, a Juri Indian, theu in the cm! ploy of Mr. Hauxwell, an Euglish bird-collector, we found it very difficult to hold steadily the long tubes. The arrows are made from the hurd rind of the leaf-stalks of certain paims, thin strips being cut, and rendered as sharp as meedles by scraping the ends with a knife or the tooth of an animal. They are winged with a little oval mass of samaüma silk (from the seed-vessels of the silk-cotton tree, Eriodendron samaüma), cotton being too hears. The ball of samauma should fit to a nicety the bore of the bluwgun; when it does so, the arrow can be propelled with such force by the breath that it makes a noise, almost as loud as a pop-gun, on flying from the muzzle. My little companion was armed with a quiver full of these little missiles, a small number of which, suificient for the diay's sport, were tipped with the fatal Urari poison. The quiver was an ornamental affair, the broad rim being mude of highly polished wood of a rich cherry-red color (the Moira-piránga, or red-wood of the Japurá). The body was formed of neatly pluited strips of Maranta stalks, and the belt by which it was suspended from the shoulder was decorated with cotton fringes and tassels.

We walked about two miles ulong a welltrodden pathway, through high caäpoeira (secoud-growth forest). A large propontion of the trees were Melastomas, which bore a hairy yellow fruit, nearly us large and is well fluvored as our gooseberry. The season, however, was nearly over for them. Tlic road was bordered every inch of the way by a thick bed of elegant Lycopodiums. An artificial arrangement of trees and bushes could scarcely have been made to wear so finished an appearance as this naturally decorated avenue. The path at length ter. minated at a plantation of mandioca, the largest I had yet seen since I left the neigllborhood of Parí. There were probably ten acres of cleared land, and purt of the ground was plaated with Indian corn, watermelous, and sugar-caue. Beyond this field there was only a faint hunter's track, leading towad the untrodden interior. My companion told me he had never hcard of there being any inhabitants in that direction (the south). $\mathrm{We}$ crossed the forest from this place to anothe $r$ smailer clearing, and then walked, on our road home, through about two miles of 
caäpoeira of various ages, the sites of old plantations. The only fruits of our ramble were a few rare insects and a Japú (Cassicus cristatus) a handsome bird with chestnut and saffron-colored plumage, which wanders 1hrough the tree-tops in large flocks. My little companion brought this down from a height which I calculated at thirty yards. The blow-gun, however, in the hands of an expert adult Indian, can be made to propel arrows as to kill at a distance of fifty and sixty yards. The aim is most certain when the tube is held vertically, or nearly so. It is a far tnore useful weapon in the forest than a gun, for the report of firearms alarms the whole flock of birds or monkeys feeding on a tree, while the silent poisoned dart brings the animals down one by one, until the sportsman has a heap of slain by his side. Nove but the stealthy Indian can use it effectively. The poison, which must be fresh to kill speedily, is obtained only of the Ind:ans who live beyond the cataracts of the rimers flowing from the north, especially the Rio Negro and the Japurí. Its principal ingredient is the wood of the Strychnos toxifera, a tree which does not grow in the humid forests of the river plains. A most graphic account of the Urari, and of un expedition undertaken in search of the tree in Guiana, has been given by Sir Robert Schomburgk.* When we returned to the house after midday, Cardozo was still sipping cauím, and now looked exceedingly merry. It was fearfully hot: the good fellow sat in his hammock with a cuya full of grog in his hands; his broad honest face ull of a glow, and the perspiration streaming down his uncovered breast, the unbuttoned shirt having slipped half way over his broad shoulders. Pedrouassú had not drunk much; he was noted, as I afterward learned, for his temperance. But he was standing up, as I left him two hours previously, talking to Cardozo in the same monotonous tones, the conversation apparently not having flagged all the time. I had never heard so much talking among Indians. The widower was asleep: the stirring, managing old lady with her daughter were preparing dinner. This, which was ready soous after I entered, consisted of boiled fowls and rice, seasoned with large green peppers and lemon-juice, and piles of new, fragrant farinha and raw banauas. It was served on plates of English manufacture on a tupé, or large plaited rush mat, such as is made by the natives pretty generally on the $\Delta$ mazins. Three or four other Indians, men and women of iniddle age, now made their appearance, und joined in the meal. We all sat round on the floor, the women, accord ing to custom, not eating until ufter the men lad done. Before sitting down our host apologized, in his usual yuiet, co teous manner, for not having knives and forks; Carlozo rad I ate by the aid of wooden spoons. the Indians using their fingers. The old man

* Annals and Magazine of Natural History, vol. vii. 5. 411 . waited until we were all served before ho himself commenced. At the end of the meal one of the women brought us water in a painted clay basin of Indian manufacture, and a clean but coarse cotton napkin, that we might wash our hands.

The horde of Passés of which Pearo-uassú was Tushaúa or chieftain, was at this time reduced to a very small number of individuals. The disease mentioned in the last chapter had for several generations made great havoc amung them ; many also had entered the service of whites at Ega, and, of late years, intermarriages with whites, half-castes, and civilized Indiuns had been frequent. The old man bewailed the fate of his race to Carduzo with tears in his eyes. "The people of my nation," he said, " have always been good friends. to the Curíwas i whites), but before my graudchildren are old like me the name of Passé will be forgotten." In so far as the Passés have amalgamated with European immigrants or their deseeudants, and become civilized Brazilian citizens, there can scarcely be ground for lamenting their extinction as a nation; but it fills one with regret to learn how many die prematurely of a disease which seems to arise on their simply breathing the same air as the whites. The original territory of the tribe must have been of large extent, for Passés are said to have been found by the early Portuguese colonists on the Rio Negro ; an ancient settlement on that river, Barcellos, having been peopled by them when it was first established; and they formed also part of the original population of Fonte-boa un the Solimuens. Their hordes were therefore spread over a region 400 miles in length from east to west. It is probable, bowever, that they have been confounded by the colonists with other neighboring tribes who tattoo their faces in a similar manner. The extinct tribo of Yurimaúas, or Suriméas, from which the river Solimoens derives its nawe, according to truditions extant at Ega, resembled the Passés in their slender tigures and friendly disposition. These tribes (with others lying betwers. them) peopled the banks of the main river and its by-streams from the mouth of the Rio Negro to Peru. True Passés existed in their primitive state on the banks of the Issá, 240 miles to the west of Ega. within the memory of living persons. The only large body oi them now extunt are located on the Japura, at a place distant about 150 miles from Ega: the population of this horde, however, does not exceed, from what I could learn, 300 or 400 persons. I think it probable that the lower part of the Japurá and its extensive delta lands formed the original home of this gentle tribe of Indians.

The Passés ure always spoken of in this country as the most adranced of all the Indian nations in the Amazons region. Under what influences this tribe has become so strongly modified in mental, social, and bodily feutures it is hard to divine. The industrious habits, fidelity, and mililness of disposition of the Passes, their ducility and. 
It may be added, their personal beauty, es-' vecially of the children and women, made them from the first very attractive to the Portuguese colonists. They were, consequently, enticed in great numbers from their villuges and brought to Barra and other settlements of the whites. The wives of governors und military officers from Europe were always eager to obtain children for - domestic servants, the girls being taught to sew, cook, weave hammocks, manufacture pillow-lace, and so forth. 'They have been generally treated with kindness, especially by the educated fumilies in the settlements. It is pleasant to bave to record that $I$ never heard of a deed of violence perpetrated; on the one side or the other, in the rlealings betireen European settlers and this noble tribe of suvages.

We started on our return to Ega at halfpast four o'clock in the afternoun. Our g'nerons entertainers lcaded us $w$ ith presents. There was scarcely room for us to sit in the canoe, as they had sent down ten large bundlas of sugar-cane, four buskets of farinha, three cedar planks, a small humper of coffee, and two heavy bunches of bananas. After we were embarked the old lady came with a partiug gift for me-a huge bowl of smoking hot banana porridge. I was to eat it on the road," to keep my stomach warm." Both stoou on the bank as we pushed off, and gave us their adeos, "Ikuána Tupána eirúm" (Go with God): a form of salutation taught by the old Jesuit missionaries. We had a must uncomfortable pussage, for Carlozo was quite tipsy, and had not attended to the loading of the boat. The cargo had been placed too far forward, and to make matters worse my heavy friend obstinately insisted on sitting astride on the top of the pile, instead of taking his place near the stern; singing from his perch a most indecent lovesong, and disregurding the inconvenience of having to bend down almost every minute to pass under the boughs and hanging sipós as we sped rapidly along. The canoe leaked, but not at first alarmingly. Lung before sunset durkness beyan to close in under these glunmy shades, and our steersman could not stroil now and then running the boat into the thic:ket. The first time this happened a piece was broken off the square prow (rodel3i): the secund time we got squeezed beI ween two trees. A short time after this lat. ter accident, being seated near the stern, with my feet on the bottom of the bout, I felt rither suddenly the cold water above my ankles. A few minutes more and we should have sunk, for a seam had been opened for. ward under the pile of sugar-cane. Two of us begun to bale, and by the most strenuous efforts manuged to keep afloat without throwing overboard our cargo. The Indians were obliged to paddle with extreme slowness to avoid shipping water as the edge of our prow was nearly level with the surfice ; but Cardozo was now persuaded to cliange his seat. The sun set, the quick twilight passed, and the meon soon after begun to glinmer through the thick canops of foliage. The prospect of being 8 wamped in this hideous solitude was by no means pleasant, although I calculated on the chance of swimming to a tree and finding a nice snuy place in the fork of some large bcugh wherein to pass the night. At length, after four hours' tedious progress. we suddenly emerged on the open stream, where the moonlight glittered in broad sheets on the gently rippling waters. A little extra care was now required in paddling. The Indians plied their strokes with the greatest nicety; the lights of Ega (the oil-lumps in the houses) soon appeared beyond the bluck wall of forest, and in a short time we leaped safely ashore.

A few months after the excursion just narrated, I accompanied Cardozo in many wanderings on the Solimoens, during which we visited the praias (sand islands), the turtle pools in the forests, and the by-streans and lakes of the great desert river. His object was mainly to superintend the business of digging up turtle eggs on the sand-banks, haviug been elected commandante for the year, by the municipal council of Ega. of the "praia real" (royal sand island) of Shimuni, the one lying nearest to Egu. These ure four of these royal praias within the Ega district (a distance of 150 miles from the town), all of which are visited annually by the Ega people for the purpose of collecting eggs and extracting oil from their yolks. Each has its commander, whose business is to make arrangements for securing to every inhabitant an equal chance in the egg harvest, by placing sentinels to protect the turtles while laying, anci so forth. The preg. nant turtles descend from the interior pools to the main river in July and August, before the outlets dry up, and then seek in countles 3 swarms their favorite sand islands; for it is only a few praias that are selected by them out of the great number existing. Thu young unimals remain in the pools through. out the dry season. These breeding-places of turtles then lie twenty to thirty or more feet above the level of the river, and are accessible only by cutting roads through th dense forest.

We left Ega on our first trip, to visit the sentinels while the turtles were yet laying, on the 26th of September. Our canoe was a stoutly-built iga.ité, arianged for ten paddlers, and having a large aiched tuldo at the stern, under which thrie persuns could sleep pretty comfortably. Emerging from the Teffe, we descended rapidly on the swift current of the Sulimoens to the south-castern or lower end of the large wooded islund of Bariá, which here divides the river into two great chaunels. We then paddled across to Shimuni, which lies in the middle of the uorth-easterly chanuel, reaching the commencement of the prais an hour tefore sun. set. The island proper is about three miles long and half a mile brond : the forest with which it is covered rises to an immense and uniform height, and presents all round u 
compact, impervious front. Here and there a singular tree, called Pao mulatto (mulatto wood), with polished dark yreen trunk, rose conspicuously among the mass of vegetation. The sand-bank, which lies at the upper end of the island, extends several miles, and presents un irregular and in some parts strongly-waved surface, with deep hollows and ridges. When upon it, one feels as though treading an almost boundless field of sand; for toward the suuth-east, where no forest line terminates the view, the white rolling plain stretches away to the horizon. The north-easterly channel of the river, lying between the sands and the farther shore of the river, is at least two miles in breadth; the middle one, between the two islands, Shimuní and Batiá, is not much less than a mile.

We found the two sentinels lodged in a corner of the praia. where it commences at the foot of the towering forest-wall of the island, having built for themselves a little rancho with poles and palm-leaves. Great precautions are obliged to be taken to avoid disturhing the sensitive turtles, who, previous to crawling ashore to lay, assemble in great shouls off the sand-bunk. The men, during this time. take care not to show themselves, and warn off any fisherman who wishes to pass near the place. Their fires are marle in a deep hollow near the borders of the forest, so that the smoke may not be visible. The passage of a boat through the shallow waters where the animals are congregated, or the sight of a man or a fire on the sand-bank, would prevent the turtles from leaving the water that night to lay their egys, and if the causes of alarm were repeated once or (wice they would forsake the praia for sume other quieter place. Soon after we arrived our men were sent with the net to catch a supply of fish for supper. In half an hour four or five large basketfuls of Acarí were brought in. The sun set soen after our meal was cooked; we were then obliged to extinguish the fire and remove cur supper materials to the sleeping ground, a spit of sand about a mile off, this course being necessary on account of the mosquitoes which swarm at night on the borders of the forest.

One of the sentinels was a taciturn, morose looking, but sober and honest Indiun, named Dauiel; the other was a noted character of Ega, a little wiry mameluco, named Carepíra (Fish-hawk), known fur his rvaggery, propensity for strong drink, and indebtedness to Ega traders. Both were intrepid canoe-men and huntsmer, and both perfectly at home anywhere in these fearful wastes of forest jand water. Carepira had his son with him, a quiet little lad of ahout nine years of age. These men in a few minutes constructed a small shed with four upright poles and leaves of the arrow-grass, under which I and Cardozo slung our hammocks. We did not go to sleep, however, until after midnight; for when supper was over we lay about on the cand with a flask of rum in our midst, ua: Whiled away the still hours in listening to
Carepira's stories.

I rose from my hammock by daylight, shivering with cold; a praia, on accuunt of the great radiation of heat in the night trom the sand, being toward the dawn the coldest place that can be found in this climate. Carduzo and the men were already up watching the turtles. The sentinels had erected for this purpose a staue about fifty feet high, on a tall tree near their station, the ascent to which was by a roughly-made ladder of woody lianas. They are enabled, by observing the turtles from this watchtower, to ascertain the date of successive deposits of eggs, and thus guide the commandante in fixing the time for the general invitation to the Ega people. The turtles lay their eggs by night, leaving the water, when nothing disturbs thern, in vast crowds, and crawling to the central aud highest part of the praia. These places are, of course, the last to go under water when, in unusually wet seasons, the river rises before the eggs are hatched by the heat of the sand. One could almost by lieve, from this, that the animals used fore thought in choosing a place ; but it is simply one of thuse many instances in animals where unconscious habit has the same result as conspious prevision. The hours between mid. night and dawn are the busiest. The turtles excavate with their broad webbed paws deep holes in the fine sand: the first comer, in each case, making a pit about three feet deep, laying its eggs (about 120 in number) and covering them with sand; the next making its deposit at the top of that of its predecessor, and so on until every pit is full. The whole body of turtles frequenting a praia does not finish laying in less than fourteen or fifteen days, even when there is no interruption. When all have done, the area (called by the Brazilians taboleiro), over which they have excavated, is distinguishable from the rest of the praia only by signs of the sand having been a little disturbed.

On rising I went to join my friends. Few recollections of my Amazonian rambles are more virid and agreeable than that of my walk over the white sea of sand on this cuol morning. The sky was cloudless; the justrisen sun was hidden behind the dark mass of woods on Shimuni, but the long line of forest to the west, on Bariá, with its plumy decorations of palms, was lighted up with his yellow, horizontal rays. A faint chorus of singing birds reached the ears from across the water, and flocks of gulls and plovers were crying plaintively over the swelling banks of the praia, where their eggs lay in nests made in little hollows of the sand. Tracks of stray turtles were visible on the smooth white surface of the praia. The animals which thus wander from the main borly are lawful prizes of the sentinels; they hid caught in this way two before suntise, cne of which we had for dinner. In my walk I disturbed several pairs of the chocolate and drab-colored wild-goose (Anser jubatus), which set off to run along the edge of the 
water. The enjoyment one feels in rambling nver these free, open spaces, is no doubt enhanc:ed by the novelty of the scene, the change being very great from the monotonous landscape of forest which everywhere else presents itself.

On arriving at the edge of the forest I muunted the sentinel's stage, just in time to see the turtles retreating to the water on the opposite side of the sand-bank, after having laid their eggs. The sight was well worth the trouble of ascending the shaky ladder. 'They were about a mile off, but the surface of the sands was blackened with the multitudes which were waddling toward the river; the margin of the prais was rather steep, and they all seemed to tumble hearl first down the declivity into the water.

I spent the morning of the $27 \mathrm{tb}$ collecting insects in the woods of Shimuni, assisting my friend in the afternoun to beat a large p ool for Tracajás, Cardozo wishing to obtain a supply for his table at home. The pool was nearly a mile long, and lay on one side of the island between the forests and the sand-bank. The sunds are heaped up very curiously around the margins of these isolinted sheets of water; in the present case they formed a steeply-inclined bank, from five to eight feet in height. What may be the cause of this formation I cannot imagine. The pools always contain a quantity of imprisoned fish, turtles, Tracajás, and Aiyus'sás. The turtles and Aiyussás crawl out voluntarily in the course of a few days, and escape to the main river, but the Tracajás remain and become an easy prey to the natives. The ordinary mode of obtaining them is to whip the water in every part with rods for several hours during the day, this treatment having the effect of driving the animals out. They wait, however, until the uight following the beating before making their exit. Our Indians were occupied for many hours in this work, and when night came they aud the sentinels were placed at intervals along the edge of the water, to be ready to capture the runawa,vs. Cardozo and I, after supper, went and toos our station at one end of the pool.

We did not succeed, after yll our trouble, in getting many Tracajás. This was partly owing to the intense darkness of the night, and partly, doubtless, to the sentiuels having already nearly exhausted the pool, notwithstanding their declarations to the contrary. In waiting for the animals it was necessary to keep silence : not a pleasant way of passing the night, speaking only in whispers, and being without fire in a place liable to be visited by a prowling jaguar. Cardozo und I sat on a sandy slope with our loaded guns by our side, but it was so dark we could scarcely see each other. Toward midnight a storm began to gather around us. The faint wind which had breathed from over the water, siuce the sun went down, ceased; thick clouds piled themselves up until every star was obscured, and gleams of watery lightning began to play.
In the midst of the black masses. I hinted to Cardozo that I thought we had now had enough of watching, and suggested a cigarette. Just then a quick pattering movement was heard on the sands, and grasping our guns we both started to our feet. Whatever it might have been it seemed to pass by, and a few moments ufterward a dark body appeared to be moving in another direction on the opposite slope of the sandy ravine where we lay. We prepared to fire, but luckily took the precaution of first shouting "Quem vai la?" (Who goes there?) It turned out to be the taciturn sentinel, Daniel, who asked us mildly whether we had heard a "raposa" pass our way. The rapusa is a kind of wild dog, with very long tapering muzzle, and black and white speckled huir. Daniel could distinguish all kinds of animals in the dark by their footsteps. It now began to thunder, and our position was getting very uncomfurtable. Daniel had not seen anything of the other Indians, and thought it was useless waiting any longer for Trucajás; we therefore sent him to call in the whole party, and made off ourselves, as quickly as we could, for the canoe. The rest of the night was passed most miserably, as indeed were very many of my nights on the Solimoens. A furious squall burst upon us; the wind blew away the cloths and mats we had fixed up at the ends of the arched awning of the canoe to shelter ourselves, and the rain beat right through our sleeping-place. There we lay, Cardozo and I, huddled together, and wet through, waiting for the morning.

A cup of strong and hot coffee put us to rights at sunrise ; but the rain was still coming down, having changed to a steady drizzle. Our men were all returned from the pool, having taken only four Tracajás. The business which had bronght Cardozo hither being now fivished, we set out to return to Ega, leaving the sentinels once more to their solitude on the sands. Our return route was by the rarely frequented north-easterly chunnol of the Solimoens, through which tluws part of the waters of its great trilutury stream, the Juputá. We travelled for five hours along the desolate, broken, timber. strewn shore of Bariá. The channel is of immense breadth, the opposite coast being visible only as a long low line of forest. At three o'clock in the afternoon we doubled the upper end of the island, and then crossed toward the mouth of the Teffé by a broad transverse channel runuing between Bariá and another island called Quanara. There is a small sund bank at the nurth-westerly point of Barı́ called Jacaié; we stayed here to dine and afterward fished witb the net. A fine rain was still falling, and we had capital sport, in three huuls taking more fish than our canoe would conveniently hold. They were of two kinds only, the Surubim and the Piraepieua (species of Pimelodus), very handsome fishes, four feet in length, with flat sponn-shaped heads, and prettilyspotted and striped skins.

On our way from Jacure to the mouth of 
the Teffé we had a little adventure with a black tiger or jaguar. We were paddling rapidly past a long beach of dried mud, when the Indians became suddenly excited, shouting "Ecuí Jauarete ; Jauarí pixúna I" (Behold the jaguar, the black jaguar !) Looking ahead, we saw the animal quietly drinking at the water's edge. Cardozo ordered the steersman ut once to put us ashore. By the time we were landed the tiger had seen us, and was retracing his steps toward the forest. On the spur of the moment, and without thinking of what we were doing, we took our guns (mine was a double-barrel, with one charge of $\mathrm{BB}$ and one of dust-shot) and gave chase. The animal increased his speed, and reaching the forest border dived into the dense mass of broad-leaved grass which formed its frontage. We peeped through the gap he had made, but, our courage being by this time cunled, we did not think it wise to go into the thicket after him. The black tiger appears to be more abundant than the spotted form of jaguar in the neighborhood of Ega. The most certain methus of finding it is to hunt, assisted by $\varepsilon$ strung of Indians shouting and driving the yame before them, in the narrow restingas or strips of dry land in the forest, which are isolated by the flocd. ing of their neighborhood in the wet season. We reached Ega by eight o'clock at night.

On the 6th of October we left Ega on a second excursion; the principal object of Cardozo befng, this time, to search certuin pouls in the forest for young turtles. The exact situation of these hidden sheets of water is known only to a few practised huntsmen; we took onc of these men with us from Ega, a mameluco named Pedro, and on our way called at Shimuni for Daniel to serve as an additional guide. We started from the praia at sunrise on the $7 \mathrm{th}$ in two canoes containing twenty-three persons, nineteen of whom wete Indians. The morning was cloudy and cool, and a fresh wind blew from down river, against which we had to struggle with all the force of our paddles, aided by the curront; the boats were tussed about most disagreeably, and shipped a great dea] of water. On pussing the lower end of Shimuni, a long reach of the river was before us, undivided by islands, a magnificent expanse of water stretching away to the south. east. The country on the left bank is not, however, terra firma, but a portion of the alluvial land which forms the extensive and complex delta region of the Japurá. It is flooded every year at the time of high water, and is traversed by many narrow and deep channels which serve as outlets to the Japurá, or al least are connected with that river by means of the interior water system of the Cupiyó. This inhospitable tract of country extends for several hundred miles, and con. tains in its midst an endless number of pools and lakes tenanted by multitudes of turtles, fishes, alligators, and wuter serpents. Our Jestination was a point on this coast situated about twenty miles below Shimuni, and a short distance from the mouth of the Ananá. one of the channels just alluded ti) as connected with the Japurá. After travelling for three hours in mid-stream we steered for the land, and brought to under a steeply-inlined bank of crumbly earth, sliaped iuto a mccession of steps or ter races, marking the various halts which the waters of the river make in the course of subsidence. The coast line was nearly straight for many miles, and the bank averaged about thirty feet in height above the present level of the ricer: at the top rose the unbroken hedge of forest. No one could have divined that pools of water existed on that elevated land. A narrow level space extended at the foot of the bank. On landing the first business was to gut breakfast. While a couple of Indian lads were employed in making the fire, roasting the fish, and boiling the cotfee, the rest of the party mounted the bank, and with their long hunting-knives commenced cutting a path through the forest; the pool, called the Aningal, being about half $\mathbf{a}$ mile distant. After breakfast a great number of short poles were cut and were laid crosswise on the path, and then three light montarias which we had brought with us were dragged up the bank by lianas, and rolled away to be embarked on the pool. A large net, seventy yalds in length, was then disembarked and carried to the place. The work was done very speedily, and when Cardozo and I went to the spot at eleven o'clock we found some of the older Indians, including Pedro and Daniel, had begun their sport. They were mounted on little stages called moutás, made of poles and crosspieces of wood secured with lianas, and were shooting the turtles as they came noar the surface, with bows and arrows. The Indians seemed to think that netting the animals, as Cardozo proposed doing, was not lawful sport, and wished first to have an hour or two's old-fashioned practice with their weapons.

The pool covered an area of abcut four or five acres, and was closely hemmed in by the forest, which in picturesque variety and grouping of trees and foliage exceeded almost everything I had yet wituessed. The margins for some distance were swampy, and covered with large tufts of a fine grass called Matupá. These tufts in many places weic overrun with ferns, and exterior to them crowded row of arborescent arums, gruwing to a height of fifteen ur twenty feet, formed a green palisade. Around the whole stood the taller forest trees ; palmate-leaved Cecropiæ ; slender Assui palms, thirty feet high, with their thin feathery heads crowning the gently-curving smouth stems; small fan-leaved palms; and as a background to ali these airy shapes, lay the voluminous masses of ordinary forest trees, with garlunds, festoons, and streamers of leaf-cliubers hanging from their branches. The pool was nowhere more than five feet deep, one fout of which was not water, but extremely fine and soft mud.

- Cardozo and I spent an hour paddling: 
about. I was astonished at the sklll which the Indians disp'ay in shooting turtles. They did not wait for their coming to the surface to breathe, but watched for the slight movements in the water which revealed their presence underneath. These little tracks on the water are called the Siriri ; the instant one was perceived an arrow flew from the bow of the nearest man, and never failed to pierce the shell of the submerged animal. When the turtle was very distant, of course the aim had to be taken at a considerable elevation, but the marksmen preferred a lingish range, because the arrow then fell more perpendicularly on the shell, and entered it wore deeply.

The arrow used in turtle shooting has a strong luncet-shuped steel point, fitted into a peg which enters the tip of the shaft. The peg is secured to the shaft by twine made of the fibres of pineapple leaves, the twine being sone thirty or forty yards in length, and neatly wound round the body of the arrow. When the missile enters the shell, the peg drops out, and the pierced animal descends with it toward the bottom, leaving the shaft floating on the surface. This being doue, the spurtsman paddles in his montaria to the place, and gently draws the animal by the twine, humoring it by giving it the rein when it plunges, until it is brought again near the surface, when he strikes it with a second arrow. With the increased hold given by the two cords he has then no difficulty in landing his game.

By mid-day the men had shot about a score of nearly full-grown turtles. Cardozo then gave orders to spread the net. The spongy, swampy nature of the banks made it impossible to work the net so as to draw the bouty ashore; another method was therefore adopted. The net was taken by two Indians and extended in a curve at one extremity of the uvul-shaped pool, holding it when they had done so by the perpendicular rods fixed at each end ; its breadth was about equal to the depth of the water, its shotted side therefore rested on the buttom, while the floats buoyed it up on the surface, so that the whole, when the ends were brought together, would form a complete trap. The rest of the party then spread themselves around the swamp at the opposite end of the pool, und begun to beat, with stout poles, the thick tufts of Matupá, in order to drive the turtles toward the middle. This was continued for an hour or more, the beaters gradually draw. ing nearer to each other, and driving the hosts of animals before them; the number of little snouts constantly popping above the surface of the water showing that all was going on well. When they neared the net, the men moved more quickly, shouting and beating with great vigor. The ends of the net were then seized by several strong hands aud dragged suddenly forward, bringing them at the sume time tingether, so as to inclose all the bonty in a circle. Every man now leaped iuto the inclosure, the bouts were brouglit 11). sill the turtles easily captured bv. Ihe hand and tossed into them. I jumped in along with the rest, although $I$ hud just before made the discovery that the poul abounded in ugly, red, four-ungled leeches, having seen several of these delectable animals, which sometimes fasten on the legs of fishermen, although they did not, on this day, trouble us, working their way through crucks in the bottom of our muntaria. Cardozo, who remained with the bouts, could not turn the animals on their backs fast enough, so that a great many clambered out and got free again. However, three boatlouds, or about eighty, were secured in about twenty minutes. They were then taken ashore, and each one secured by the men tying the legs with thongs of bust.

When the canoes had been twice filled we desisted, after a very hard day's work. Nearly all the animals were young ones, chiefly, according to the statement of Pedro, from three to ten years of age : they varied from six to eighteen inches in length, and were very fat. Cardozo and I lived almost exclusively on them for several months afterward. Roasted in the shell they form a most appetizing dish. These young turtles never migrate with their elders on the sinking of the waters, but remain in the tepid pools, fattening on fallen fruits, and, accorcing to the natives, on the fine nutritious mud. We captured a few full-grown mother-turtles, which were known ut once by the horny skin of their breast-plates being worn, telling of their having crawled on the sands to lay eggs the previous year. They hud evidently made a mistake in not leaving the puol at the proper time, for they were full of eggs, which, we were told, they would, before the season was over, scatter in despuir over the swamp. We also found severul male turtles, or Capitalis, as they are called by the natives. These are immensely less numerous than the females, and are distinguishable by their much smaller size, more circular shape, and the greater length and thickness of their tails. Their flesh is considered unwliolcsome, especially to sick people having external signs of inflummation. All diseases in these parts, as well as their remedies, and ull articles of feod are classed by the inlubitants as "hot" and "cold," aud the meat of the Capitarí is settled by ununimous conscut as belouging to the "hot" list.

We dined on the banks of the river a little before sunset. 'The mosquitoes then begnn to be troublesome, and finding it would be impossible to sleep here, we all embarked and crussed the river to a saud-bank, about thrce miles distant, where we passed the niglit. Cardozo and I slept in our hammocks slung between upright poles, the rest stretching themselves on the sand round a litge fire. We lay awake conversing until pusi mid. night. It was a real pleasure to listen to the stories told by one of the older men, they were given with so much spirit. The tales always related to struggles with some intructahle animal-jaguar; manatee, or alligator. I..j-j interjections and expressive g.stures 
were used, and at the end came a sudden "Pa! terra!" when the animal was vanquished by a shot or a blow. Many mysterious tales were recounted about the Bouto. us the large Dolphin of the Amazons is called. One of them was to the effect that a Bouto once had the habit of assuming the shape of a beautiful womau, with hair hanging loose to her heels, and walking ashore at night in the streets of Ega, to entice the young men down to the water. If uny one was so much smitteu as to follow her to the water-side, she grasped her victim lound the waist and plunged beneath the waves with a triumphant cry. No snimal in the Amazons region is the subject of so many fables as the $B$ outo; but it is probable these did not originate with the Indians, but with the Portuguese colonists. It was several years before I could induce a fisherman to harpoon dolphins for me as specimens, for no one ever kills these animals voluntarily, although their fat is known to yield an excellent oil for lamps. The superstitious people believe that blindness would result from the use of this oil in lamps. I succeeded at length with Carepira, by offering him a high reward when his finances were at a very low point; but he repented of his deed ever afferward, declaring that his luck had forsuken him from that day.

The next morning we again beat the pool. Although we had proof of there being a great number of turtles yet remaining, we had very poor success. The old Indians told us it would be so, for the turtles were "ladiuo" (cunning), and would take no notice of the beating a second day. When the net was formed into a circle, and the men had jumped in, an alligator was found to be inclosed. No one was alarmed, the only fear expressed being that the imprisoned beast would tear the net. First one shouted, "I have touched his head ;" then another, "he Las scrutched my leg." One of the men, a lanky Miránha, was thrown off his balance, and then there was no end to the laughter and shouting. At last a youth of about fourteen years of age, on my calling to him, from the bunk, to do so, seized the reptile by the tail, and held him tightly until, a little resistance being overcome, he was able to bring it ashore ; the net was opened, and the boy slowly dragged the dangerous but cowardly beust to land through the muddy water, a distance of about a hundred yurds. Meantime I had cut a strong pole from a tree, and as soon as the alligator was drawn to solid ground, yave him a smart rap with it on the crown of his head, which killed him instant1y. It was a good-sized individual ; the jaws being considerably more than a foot long, and fully capuble of suapping a man's leg in twain. The species was the large cuymun, the Jacaré-uassú of the Amazonian Indians (Jacare nigra).

On the third day we sent our men in the boats to net turtles in a larger pool, about five miles farther down the river, and on the fourth returned to Egu.
It will be well to mention here a few cir. cumstances relative to the large cayman, which, with the incident just narrated, aftord illustrations of the cunning, cowardice, and ferucity of this reptile.

I have hitherto had but few occasions of mentioning alligators, although they exist by myriads in the waters of the Upper Amazons. Many different species are spoken of by the natives. I saw only three, and of these two only are common : one, the Jacarétinga, a small kind (five feet long when full grown), having a long slender muzzle, and a black-banded tail ; the other, the Jacareuassú, to which these remarks more especially relate; and the third the Tacaré-curúa, mentioned in a former chapter. The Jacaréuassú, or large cayman, grows to a length of eighteen or twenty feet, and attains an enormous bulk. Like the turtles, the alligator has its unnual migrations, for it retreats to the interior pools and fluoded forests in the wet season, and descends to the main river in the dry season. 'During the months of high water, therefore, scarcely a single individual is to be seen in the main river. In the middle part of the Lower Amazons, about Obydos and Villa Nova, where many of the lakes with their channels of communication with the trunk stream dry up in the fine months, the alligator buries itseif in the mud and becomes dormant, sleeping till the rainy season returns. On the Upper Amazous, where the dry season is never $\epsilon$ cessive, it has not this habit, but is lively all the year round. It is scarcely exaggerating to say that the waters of the Sólimoens are as well stocked with large alligators, in the dry season, as a ditch in England is in summer with tadpoles. During a journey of five days which I once made in the Upper Amazons steamer, in November, alligators were seen along the coast almost every step of the way, and the passengers amused themselves, from morning till night, by firing at them with rifle and ball. They were very numerous in the still bays, where the huddled crowds jostled together, to the great rattling of their coats of muil, as the steamer passed.

The nutives at once despise and fear the great cayman. I once spent a month at Cuiçara, a small village of semi-civilized Indians, about twenty miles to the west of Ega. My entertuiner, the only white in the place, and one of my best and most constant friends, Senhor Innucencio Alves Faria, one day proposed a half-day's fishing with net in the lake, the expanded bed of the small river on which the village is situated. We set out in an open boat with six Indians and two of Innocencio's children. The water had sunk so low that the net had to be taken out into the middle by the Indians, whence at the first draught two medium-sized alligaturs were brought to land. Then were disengaged from the net and allowed, with the coolest unconcern, to return to the water, although the two children were playing in it not many yards otf. We continued fishing, Innucencio and I lending a helping had. and each time 
drew a number of the reptiles of different ages and sizes, some of them Jacaré-tingas ; the lake, in fact, swarmed with ulligators. After taking a very large quantity of tish we prepared to return, and the Indians, at my suggestion, secured one of the alligators with the view of letting it loose amung the swarms of dogs in the village. An individual was selected about eight feet long : on€ man holding his head and another his tril, while a ithird took a few lengths of a flexible liana, 'and deliberately bound the jaws and the legs. Thus secured, the beast was laid across the itbenches of the boat, on which we sut during the hour and a half's journey to the settlement. We were rather crowded, but our l amiable passenger gave us no trouble during the transit. On reaching the village we took the animal into the middle of the green, in front of the church, where the dogs were congregated, and there gave him his liberty, two cf us arming ourselves with long poles to intercept him if he should make for the water, and the others exciting the dogs. The alligator showed great terror, although the doys could not be made to advance, and made off at the top of its speed for the water, waddling like a duck. We tried to keep him back with the poles, but he became enraged, and seizing the end of the one I held, in his jaws, nearly wrenched it from my grasp. We were obliged, at length, to kill him to prevent his escape.

These little incidents show the timidity or cowardice of the alligator. He never attacks man when his intended victim is on his guard; but he is cunning envugh to know when this may be done with impunity: of this we had proof at Caiçara, a few days afterward. The river had sunk to a very low point, so that the port and bathing-place of the village now lay at the foot of a long sloping bank, and a large cayman made his appearance in the shallow and muddy water. We were all obliged to be very careful in taking our bath; most of the people simply using a calabash, pouring the water over themselves while standing on the brink. A large trading canve, helonging to a Barra merchant named Soares, arrived at this time, and the Indian crew, us usual, spent the first day or two after their coming into port in drunkenness and debauchery ashore. One of the men, during the greatest heat of the day, when almost every one was enjoying his afternoon's nap, took it into his bead while in a tipsy state to go duwn ulone to bathe. He was seen only by the Juiz de Paz, a feeble old man who was lying in his hammock, in the open veranda at the rear of his house on the top of the bank, and who shouted to the besotted Indiau to beware of the alligator. Before he could repeat his warning the man stumbled, and a pair of gaping jaws, appearing sud. denly above the surface, seized him round the waist and drew him under the water. A cry of agony, "Ai Jesús !" was the last sign wsde by the wretched victim. The village was aroused: the young men with praise. worthy readiness seized their harpoons and hurried down to the bank : but of course it was too late; a winding track of blood on the surface of the water was all that could be seen. They embarked, however, in montarias, determined on vengeance : the monster was traced, and when, after a short lapse of time, he came up to breathe-one leg of the man sticking out from his jaws-was dispatched with bitter curses.

The last of these minor excursions which I shall narrate, was mude (again in company of Senhor Cardozo, with the addition of his housekeeper, Senhora Felippa) in the season when all the population of the villages turns out to dig up turtle eggs, and revel on the praias. Placards were posted on the church doors at Ega, announcing that the excavation on Shimuni would commence on the $17: 1$. of October, and on Catuá, sixty miles below Shimuni, on the 25th. We set out on the 16 th, and passed on the road, in our wellmanned igarité, a large number of people, men, women, und children, in canoes of all sizes, wending their way as if to a great holi. day gathering. By the morning of the 17th some 400 persons were assembled on the borders of the sand-bauk, each family having erected a rude temporary shed of poles and palm-leaves to protect themselves from the sun and rain. Large cupper kettles to prepare the oil, and hundreds of red earthenw are jars, were scattered about on the sand.

The excavation of the taboleiro, collecting the eggs, and purifying the oil occupied four days. All was done on a system established by the old Portugue e governors, probably more than a century ago. The commandante first took duwa the names of all the masters of households, with the number of persons each intended to employ in digging; he then exacted a payment of 140 reis (about fourpence) a head toward defraying the expense of sentinels. The whole was then allowed to go to the taboleiro. They runged themselves round the circle, each person armed with a paddle, to be used as a spade, and then all began simultaneously to dig on a signal being given - the roll of drums -by order of the commandante. It was an animating sight to behold the wide circle of rival diggers throwing up clouds of sand in their energetic labors, and working gradually toward the centre of the ring. A little rest was taken during the great heat of mid-day, and in the evening the eggs were carried to the huts in baskets. By the end of the second day the taboleiro was exhausted : lurge mounds of eggs, some of them four or five feet in height, were then seen by the side of each hut, the produce of the labors of the family

In tho hurry of digging some of the deeper nests are passed over; to find these out the people go about provided with a long steel or wooden probe, the presence of the eggs. being discoverable by the euse with which the spit enters the sand. When no more eggs. 
are to be found, the mashing process begins. The egg, it may be mentioned, has a flexible -or leathery shell; it is quite round, and somewhat larger than a hen's egg. The whole beap is thrown into an empty canoe and mashed with wooden prongs ; but sometimes naked Indians and children jump into the mass and tread it down, besmearing them. selves with yolk and making about as filthy I scene as can well be imagined. This being finished, water is poured into the canoe, and the fatty mass then left for a few hours to be heated by the sun, on which the oil separates and rises to the surface. The floating oil is :afterward skimmed off with long spoons, made by tying large mussel-shells to the end of rods, and purified over the fire in copper kettles.

The destruction of turtle-eggs every year by these pruceedings is enormuus. At least 6000 jars, holding each three gallons of the oil, are exported anuually from the Upper Amazons and the Madeira to Pará. wbere it js used for lighting, frying fish, and other purposes. It may be fairly estimated that 2000 unore jarfuls are consumed by the in. labitants of the villages on the river. Now, it takes at ieast twelve basketfuls of eggs, or about 6000 , by the wasteful process followed, to make one jar of oil. The total number of eggs annually destroyed amounts, therefore, to $48,000,000$. As each turtle lays about 120 , it follows that the yearly offspring of 400,000 turtles is thus annihilated. A vast number, nevertheless, remain undetected ; and these would probably be sufficient to keep the turtle population of these rivers up to the mark, if the people did not follow the wasteful practice of lying in wait for the newly-hatched young, and collecting them by thousands for eating; their tender flesh and the remains of yolk in their entrails being considered a great delicacy. The chief uatural enemies of the turtle are vultures and alligaturs, which devour the newly-hatched young as they descend in shoals to the water.

These must have destroyed an immensely greater number before the European settlers began to appropriate the eggs than they do now. It is almost doubtful if that natural persecution did not act as effectively in checking the increase of the turtle as the artificiul destruction now does. If we are to believe the tradition of the Indians, however, it hild not this result; for they say that formerly the waters teemed as thickly with turtles as the air does now with mosquitoes. The universal opinion of the settlers on the Upper Amazuns is, that the turtle has very greatly decreased in numbers, and is still annually decreasing.

We left Shimuni on the 20th, with quite a flotilla of canoes, and descended the river to Catuá, un eleven hours' journey by paddle and current. Catuá is about six miles long, and almost entirely encircled by its praia. The turtles had selected for their egg-laying a part of the sand-bank which was elevated at least twenty feet above the present lorv: of the river ; the animals, to reach the place, must have crawled up a slope. As we approached the island, numbers of the animals were seen coming to the surface to breathe, in a small shualy bay. Those who had light montarias sped forward with bows and arrows to shoot them. Carepira was foremost, having borrowed a small and very unsteady boat of Cardozo, and embarked in it with his little son. After bagging a couple of turtles, and while hauling in a third, he overbalanced himself ; the eanoe went over, and he with his child had to swim for their lives, in the midst of numerous alligators, about a mile from the land. The old man had to sustain a heavy fire of jokes from his companions for several days after this mishap. Such accidents are only laughed at by these almost amphibious people.

The number of persons congregated on Catuá was much greater than on Shimuní, as the population of the banks of several neigh. boring lakes was here added. The line of huts and sheds extended half a inile, and several large sailing vessels were anchured at the place. The commandante was Senbor Macedo, the very worthy Indian blacksmith of Ega, who maintained excellent order during the fourteen days the process of excuvation and oil manufacture lasted. There were ulso many primitive Indians here from the neighboring rivers, among them a family of Shumánas, yood-tempered, harmless people from the Lower Japurá. All of them were tattooed round the mouth, the bluish tint forming a border to the lips, and extending in a liue on the cheeks toward the ear on each side. They were not quite so slender in figure as the Passés of Pedro-uassú's family; but their features deviated quite as much as those of the Passés from the ordinary Iudian type. This was seen chiefly in the comparatively small mouth, pointed chin, thin lips, and narrow, high nose. One of the duughters, a young girl of about seventeen years of age, was a real beauty. The color of her skin approached the light tanned shade of the Mameluco women; her figure was almost faultless, and the blue mouth, instead of being a disfigurement, gave quite a captivating finish to her appearance. Her neck, wrists, and ankles were adorned with strings of blue beads. She was, however, extremely bashful, never venturing to look strangers in the face, and never quitting, for many minutes together, the side of her father and mother. The family had been shame. fully swindled by some rescally trader on another praia; and, on our arrival, came to lay their case before Senhur Cardozo, us the delegado of police of the district. The inild way in which the old man, without a trace of anger, stated his complaint in imperfect Tupí, quite enlisted our sympathies in his favor. But Cardozo could give him no redress; he invited the family, however, to inake their rancho near to ours, und in the end gave them the highest price for the surplus oil which they manufactured.

It was not all work at Catuá; indeed there 
was ratuer nore play than work goins on. 'The people make a kind of holiday of -nese occasions. Every fine night psities cf the younger peopie assembled on the sunds, and daucing and yames were carrieri on for hours together. But the requisite liveliness for these sports was never ght up without a goud deal of preliminury rum-lrinking. The girls were so coy that the young men could not get sufficient partners for the dances, without tirst subscribing for a few flagous of the needful cashaç. The coldness of the shy Indian and Mameluco maidens never failed to give way after a little of this strong drink, but it was astonishing whut an immense deal they could take of it in the course of an evening. Covness is not always a sign of innocence in these people, for most of the halfcaste women on the Upper Amuzons lead a little career of louseness hefore they marry and settle down for life ; and it is rather remarkable that the men do not seem to object much to their brides having had a child or two by various fathers before marriage. The womeu do not lose reputation unless they become utterly depraved, but in that case they are condemned pretty strongly by public opinion. Depravity is, however, rare, for all require more or less to be wooed before they are won. I did not see (althougin I mixed pretty freely with the young people) any breach of propriety on the praias. The merry-makings were carried on pear the ranchos, where the more staid citizens of Ega, husbands with their wives and young daughters, all smoking gravely out of long pipes, sat in their hammocks and enjoyed the fun. Toward midnight we often heard, in the intervals between jokes and laughter, the hoarse roar of jaguars prowling about the jungle in the miadle of the praia. There were several guitar-players among the young men, and one must persevering fiddler, so there was no lack of music.

The favorite sport was the Pira-purasseyu, or tish dance, one of the original gumes of the Indians, though now probably $a$ little modified. The young men and women, n..ingling together, formed a ring, leaving nne of their number in the middle, who represeuted the fish. They then all marched round, Indiun tile, the musicians mixed up with the rest, singing a monotouous but rather pretty chorus, the words of which were invented (under a certain form) by one of the party who acted as leader. This finished, all joined hands, and questions were put to the one in the middle, asking what kind of fish he or she might be. To these the individual has to reply. The end of it all is that he makes a rush at the ring, and if he succeeds in escaping, the person who allowed him to do so has to take his place; the march and chorus then recommence, and so the game gues on hour after hour. Tupi was the language inostly used but sometimes Portuguese was sung and spokeu. The details of the dance were often varied. Instead of the natnes of fishes being called over by the person in $1 \mathrm{~T}$. middle, the name of some animal, dower, or other object was given to every fresh occupier of the place. There was theu good scopefor wit in the invention of nicknames, and peals of laughter would often sulute some particularly gnod hit. Thus a very lanky young man wus called the Magoary, or the: gray stork; a moist, gray-eyed man, with u profile comically suggestive of a fish, was. christened Jarakí (a kind of fish), which was considered quite a witty sally ; a little Mameluco girl, with light-colored eyes and brown. hair, got the gallant name of Rosa branca, cr the white rose; a young fellow who had recentlv singed his eyebrows by the explc. sion of fireworks was dubbed Pedro yueimado (burnt Peter) ; in short, every one got a. nickname, and each time the cognomen was. introduced into th horus as the circle. marched round.

Our rancho was $\varepsilon$ large. one, and was erected in a line with the others, near the edge of the sand-bank which sloped rather abruptly to the water. During the first. week the people were all, more o: less, troubled by alligators. Some half-dozen fullgrown ones were in attendance off the praia. flouting about on the lazily flowing muddy water. The diyncss of the weather had in creased since we had left Shimuni, the currents had slackened, and the heat in the middle part of the day was almost insupportable. But no one could descend to bathe withuut being advanced upon ly one or other of these hungry munsters. There was much offal cast into the river, and this of course attracted them to the place. One day 1 amused myself by taking a basketful of fragments of meat beyond the line of ranchos, und drawing the alligators toward me by feeding them. They behaved pretty much as dogs do when fed; catching the bones I threw them in their huge jaws, and coming nearer and showing increased eagerness after every morsel. The enormous gape of their mouths, with their blood-red lining and long fringes: of teeth, and the uncouth shapes of theirbodies, made a picture of unsurpussable ugliness. I once or twice fired a heavy charge of shot at them, aiming at the vulnerable part of their bodies, which is a small space situated behind the eyes, but this lad no other effect than to make them give a hoarse grunt and shake themselves; they imme diately afterward turned to receive another bone which I threw to them.

Every day these visitors became bolder ; at length they reached a pitch of impudence that was quite intulerable. Cardozo had a poodle dog named Carlito, which some grateful traveller whom he had befriended had sent him from Rio Janeiro. He took great pride in this dog, keeping it well sheared, and preserving his coat as white as soap and water could make it. We slept in our ranchu in hammocks slung betwecn the outer posts; a large wood fire (fed with a kind of wood abundant on the banks of the river, which keeps alight ull night) heing made in the middle, by the side if which slept Carlico on .a little mat. 
by a great uproar. It was caused by Car. dozo luurling lourning frewood with loud curses at a luge cayman which hud crawled up the bink and passed beneath my hammock (being nearest the water) tuward the place where Carlito lay. The dog had raised the alim in time; the reptile backed out and tumbled down the bank to the water, the sparks from the brands hurled at himflying from his bony hide. To our great surprise the animal (we supposed it to be the same individuul) repeated his visit the very next night, this time passing round to the other side of our slied. Cardozo was awuke, and threw a harpoon at him, but without doing him any liarm. After this it wis thought necessary to muke an effort to check the alligators ; a number of men were therefore persuaded to sally forth in their montarias and devote a day to killing them.

The young men made several hunting excursions during the fourteen days of our stay on Catuá, and I, being associated with them in all their plcasures, made generally one of the party. These were, besides, the sole occasions on which I could add to my collections, while on these barren sands. Only two of these trips afforded incidents worth relating.

The first, which was made to the interior of the wooded island of Catuá, was not r very successful one. We were twelve in number, all armed with guns and loug hunting knives. Long before sunrise my friends woke me up from my hammock, where I lay, as usual, in the clothes worn during the das ; and after taking each a cupful of cushaça and ginger (a very general practice in early morning on the sand-banks), we commenced our walk. The waning moon - still lingered in the clear sky, and a profound stillness pervaded sleeping camp, forest, and stream. Along the line of ranchos glimmered the fires made by each party to dry -turtle-eggs for food, the eggs buing spread on little wooden stages over the smoke. The distance to the forest from our place of starting was about two miles, being nearly the whole length of the sand-bark, which wus also a very broad one; the highest part, where it was covered with a thicket of dwarf willows, mimosas, and arrow-grass, lying neur the ranchos. We loitered much on the way, and the day dawned while we were yet on the road, the sand at this early hour feeling quite cold to the naked feet. As soon us choked up with tall grass, which appearerl to we were able to distinguish things, the sur- be the dried-up bed of unother lake. Our face of the praia was aeen to be dotted with leader was obliged to climb a trce to ascertain small black nbjects. These were newly- uur position, and found that the clear space hatched 1iyussa turtles, which were making was part of the creek, whose mouth we hud their way in an undeviating line to the water, crossed lower down. The banks were at least a mile distant. The young animal clothed with low trees, nearly all of one speof this species is distinguishable from that of cies, a kind of araca (Psidium), and the the large turtle and the Tracajá by the edges ground was carpeterl with a slender delicate of the breastplate being raised on each side, grass, now in flower. A great number of so that in crawling it scores two parallel lines crimson und vermilion colored butterflies on the sand. The mouths of these little creat- (Cattagramma Peristera, male and female) ures were full of sand, a circumstance aris- were settled on the smooth white trunks of ing from their having to bite their way these trees. I lad also here the great pleasthrough many inches of superincumbent ure of seeing for the first time the rare and saud, to reach the surface on emerging from surious Umbrella Bird (Cephalopterus orna- 
tus), a speeies which resembles in size, color, and appearance our common crow, but is decorated with a crest of long curved hairy feathers, having long bare quills, which, when raised, spread themselves out in the form of a fringed sunshade over the head. A strange ornament, like a pelerine, is ulso suspended from the neck, formed by a thick pad of glossy steel-blue feathers, which grow on a long fleshy lobe or excrescence. This lobe is connected (as I found on skinuing specimens) with an unusual development of the trachea and rocal organs, to which the bird doubtless owes its singularly deep, loud, and long-sustained fluty note. The Indian name of this strange creature is Uirá-minnbéu, or fife-bird, in allusion to the tone of its voice. We had the good luck, after remaining quiet a short time, to hear its per. formance. It drew itself up on its perch, spread widely the umbrella-formed crest, dilated and waved its glossy breast-lappet, and then, in giving vent to its loud prping note, bowed its head slowly forward. We obtained a pair, male and female : tise female has only the rudiments of the crest and lappet, and is duller colored altogether than the male. The range of this bird appears to be quite confined to the plains of the Upper Amazons (especially the Ygapó forests), not having been found to the east of the Rio Negro.

Bento and our other friends, being disappointed in finding no more Curassows, or indeed any other species of game, now resolved to turn back. On reaching the edge of the forest we sat down and ate our dinners under the sbade, each man having brouglst a little bag containing a few hanafuls of fariula, und a,piece of fried fish or roast turtle. We expected our companions of the other division to join us at mid-day, but after waiting till past one $0^{\circ}$ clock, without seeing anything of them (in fact, they had returned to the hits an hour or two previously), we struck off across the praia toward the encampment. An obstacle 5ere presented itself on which we had not counted. The sun had shone all day through a cloudless sky untempered by a breath of wind, and the sands had become heated by it to a degree that rendered walking over them with our bare feet impossible. The most hardened footsoles of the party could not endure the burning soil. We made several attempts : we tried running ; wrapped the cool leaves of Heliconiæ round our feet, but in no way could we step forward many yards. There was no means of getting back to our friends before night, except going round the praia, a circuit of about four miles, and walking through the water or on the moist sand. To get to the water-side from the place where we then stood was not difficult, as a thick bed of a flowering shruh, called tintarána, an infusion of the leaves of which is used to dye black, lay on that side of the sand-bank Footsore and wearied, burdened with our guns, and walking for miles through the tepid shallow water under the brain-scorching vertical sun. we had, as may be imagined, anything but a pleasant time of it. I did not, however, feel any inconvenience afterward. Every one enjoys the most lusty health while living this free and wild life on the rivers.

The cther hunting trip which I have alluded to was undertaken in company with three friendly young half-castes. Two of them were brothers, namely Joaõ (John) and Zephyrino-Jabutí ; Jabutí, or tortoise, being a nickname which their father had earned for his slow gait, and which, us is usual iu this country, had descended as the surname of the family. The other was José Frazaõ, a nephew of Senhor Chrysostomo, of Ega, an active, clever, and manly young fellow, whom I much esteemed. He was almust a white, his father being a Portuguese and his mother a Mameluco. We were accompanied by an Indian named Lino, and a nulatto boy, whose office was to carry our game.

Our proposed hunting-ground on this occasion lay across the water, about fifteen miles distant. We set out in a small montaria, at four o'clock in the morning, again leaving the encampment asleep, and travelled at a good pace up the northern channel of the Solimoens, or that lying between the island of Catuá and the left bank of the river. The northern shore of the island had a broad sandy beach reaching to its western extremity. We gained our destination a little after daybreak; this was the banks of the Carapanatúba,* a channel some 150 yards in width, which, like the Ananá, already mentioned, communicates with the Cupiyó. To reach this we had to cross the river, here. nearly two miles wide. Just as the day dawued we saw a cayman seize a laige fish, a Tambakí, near the surface; the reptile seemed to have a difficulty in securing its $\mathrm{p} \cdot \mathrm{y}$, for it reared itself above the water, tossing the fish in its jaws, and making a tremendous commotion. I was much struck also by the singular appearance presented by certain div ing birds having very long and snaky nechs (the Plotus Anhinga). Occasionally a lony serpentine form would suddenly wriggle it. self to a height of a foot and a half above the glassy surface of the water, producing such a deceptive imitation of a snake that at first I had some diffieulty in believing it to be the neck of a bird; it did not remain long in view, but soon plunged again beneath the stream.

We ran ashore in a most lonely and gluomy place, on a low sand-bank covered with bushes, secured the montaria to a tree, and then, ifter making a very sparing breakfast on fried fish and mandioca meal, rolled up our trousers and plunged into the thick forest, which here, as everywhere else, rose like a lofty wall of foliage from the narrow strip of beach. We made straight for the heart of the land, John Jabutí leading, and breuking off at every few steps a brancil of the

* Meaning in Tupi, the river of many mosquitoes : from carupauá, musquiı, and itúba, muny. 
lower trees, so that we might recognize the path on our return. The district was quite new to all my companiuns, and being on a coast almost totally uninhabited by human beings for some 300 miles, to lose our way would have beeen to perish helplessly. I did not think at the time of the risk we ran of having our canoe stolen by passing Indians, unguarded montarias leing never safe even in the ports of the villages, Indians apparently considering them common property, and stealing them without any compunction. No misgivings clouded the lightness of heart with which we trod forward in warm anticipation of a good day's sport.

The tract of furest through which we passed was Ygapó, but the higher parts of the land formed areas which went only \& very few inches under water in the flood season. It consisted of $\boldsymbol{\Omega}$ most bewildering diversity of yrund and beautiful trees, draped, festooned, corded, matted, und rib. boned with climbing plants, woody and succulent, in endless variety. The most prevalent palm was the tall Astryocaryum Jauari, whose fallen spines made it necessary to pick our way carefully over the ground, as we were all barefont. There was not much green underwood, except in places where bamboos yrew; these formed impenetrable thickets of plumy foliage and thorny jointed stems, which always compelled us to make a circuit to avoid them. The earth else. where was incumbered with rotting fruits, gigantic bean-pods, leaves, limbs, and trunks of trees, fixing the impression of its being the cemetery as well as the birthplace of the great world of vegetation overhead. Some of the trees were of prodigious height. We passed many specimens of the Moratinga, whose cylindrical trunks, I dare not say huw many feet in circumference, towered up and were lost amid the crowns of the lower trees, their lower branches, in some cases, being hidden from our view. Another very large and remarkuble tree was the Assacú (Sapium aucuharium). A traveller on the Amazons, mingling with the people, is sure to hear much of the poisonous qualities of the juices of this tree. Its bark exudes, when hacked with a knife, a milky sap, which is not only a fatal poison when taken internally, but is suid to cause incurable sores if simply sprinkled on the skin. My companious always gave the Assacú a wide berth wheu we passerl onc. The tree looks ugly enough to merit a bad name, for the bark is of a dingy olive color, and is studded with short and sharp venomous-looking spines.

After walking about hulf a mile we came upon a dry water-course, where we observed, first, the old footmarks of a tapir, and, soon after, on the margin of a curious circuJar hole full of muddy water, the fresh tracks of a jaguar. This latter discovery was hardly made when a rush was heard amid the bushes on the top of a sloping bank on the opposite side of the dried creek. We bounded forward; it was, however, too late, for the animal had sped in a few minutes far ont of our reach. It was clesr we had dis. turbed, on vur approach, the jagi:ar, while quenching his thirst at the water-hole. A few steps farther on we saw the mangled remuins of an alligator (the Jucarétinga). The head, forequarters, and bony shell were the only parts which remained; but the meat was quite fresh, and there were many foctmarks of the jaguar around the carcuss; so that there was no doubt this had formerl the solid part of the animal's breukfast. My companions now began to search for the alligator's nest, the presence of the reptile so far from the river being accountable for un $n$ ? other ground than its materval solicitude for its eggs. We found, in fact, the nest at the distance of a few yards from the place. It was a conical pile of dead leaves, in the mirldle of which twenty eggs were buried. These were of elhiytical sliape, considerably larger than those of a duck, and having in hard shell of the texture of porcelain, but very rough on the outside. They make a loud sound when rubbed together, and it is said that it is easy to find a mother alligator in the Tyapó forists by rubbing together two eggs in this way, she being never far off, and attracted by the sounds.

I put half a du\%en of the alligator's eggs in my game-bag for specimens, and we then continued on our way. Lino, who was now first, presently m:ade a start backward, call. ing out " Jararáca!" This is the name of a poisonous snuke (genus Craspedocephalus), which is far more dreaded liy the natives than jaguur or alligator. The iudividual seen by Lino lay coiled up at the foot of a tree, and was scarcely distinguishable, on account of the colurs of its body being assimilated to those of the fallen leuves. Its hideous flat triangular head. connected with the body by a thin neck, was reared and turned towurd us: Frazao killed it with a charge of shot, shattering it completely, and destroying, to my regret, its value as a specimen. In conversing on the subject of Jararácas as we walked onward, every one of the party was ready to swear that this snake at tacks man without provocation, leaping 10 . ard him from a considerable distance when he approaches. I met, in the course of $\mathrm{my}$ daily rambles in the woods, manj Jaratácas, and once or twice very narrowly cscaped treading on them, but never saw them attempt to spring. On sume subjects the tistimony of the natives of a wild country is utterly worthless. The bite of the Jararáca 3 is generally fatal. I knew of four or five in. stances of death frum it, and unly of ono clear case of recovery ufter being bitten; but in that case the person was lamed for life.

We walked over moderately eievated and dry ground for about a mile, and then descended (three or four feet only) to the dry hed of auother creek. This was pierced in the same way as the former water-course, with round holes full of muddy water. Thry or: curred at intervals of a few yards, and had t'se appearance of having been made by the 
hand of man. The smallest were about two feet, the largest seven or eight feet in diameter. As we approached the most extensive of the larger ones, I was startled ut seeing a number of large serpent-like heads bobbing above the surface. They proved to be thuse of electric eels, and it now occurred to me that the round holes were made by these animals working constantly round and round in the moist muddy soil. Their depth (some of them were at least eight feet deep) was doubtless due also to the movements of the eels in the soft soil, and accounted for their not drying up, in the fine season, with the rest of the creek. Thus, while alligators and turtles in this great inundated forest region retire to the larger pools during the dry season, the electric eels make for themselves little ponds in which to pass the season of drought.

My compunions now cut each a stout pole, and proceeded to eject the eels in order to get at the other fishes, with which they had discovered the ponds to abound. I amused them all very much by showing how the electric shock from the eels could pass from one person to another. We joined hands in a line while I touched the biggest and freshest of the animals on the head with the point of my hunting-knife. We found that this experiment did not succeed more than three times with the same eel when out of the water; for the fourth time the shock was scarcely perceptible. All the fishes found in the holes (besides the eels) belonged to one species, a small kind of Acari, or Loricaria, a group whose members have a complete bony integument. Lino and the boy strung them together through the gills with slender sipos, and hung them on the trees to await - our return later in the day.

Leaving the bed of the creek, we marched -onward, always towurd the cenore of the land, guided by the sun, which now glimmered through the thick folinge overhead. About eleven o'clock we saw a break in the forest before us, and presently emerged on the banks of a rather large sheet of water. This was one of the interior pools of which there are so many in this distric t. The margins were elevated some few feet, and sloped down to the water, the ground being hard and dry to the water's edge and covered with shrubby vegetation. We passed completely round this pool, finding the crowus of the trees on its borders teuanted by curassow -birds, whose presence was betıayed as usual by the peculiar note which they emit. My companions shot two of them. At the further end of the lake lay a deep water-course, which we traced for about half a mile, and found to communicate with another and smaller pool. This second one evidently swamed with turtles, as we saw the snouts of many peering above the surface of the water : the same had not been seen in the larger lake, probably because we had made too much noise in hailing our discovery, on approaching its bunks. My friends made ax arrangement on the spot for returning to thit pool, after the termination of the egg harvest on Catuá.

In recrossing the space between the two pools we heard the crash of monkeys in the crowns of trees overhead. The chase of these occupied us a considerable time. José fired at length at one of the laggards of the troop, and wounder him. He climbed pretty nimbly toward a denser part of the tree, and a second and a third discharge failed to bring him down. The poor maimed creature then trailed his limbs to one of the topmost branches, where we descritd him soon after, seated and plcking the entrails from a wound in his abdomen- $a$ most heartrending sight. The beight from the ground to the bough on which le was perched could not have been less than 150 feet, and we could get a ylimpse of him only by standing directly underneath, and straining our eyes upward. We killed him at last by loading our best gun with a careful charge, and resting the barrel against the tree trunk to steady the aim. A few shots entered his chin, and he then fell heels over head screaming to the ground. Although it was I who gave the final shot, this animal did not fall to my lot in dividing the spoils at the end of the day. I regret now not having preserved the skin, as it belonged to a very large species of Cebus, and one which I never met with afterward.

It was about one o'cluck in the afternoon when we again reached the spot where we had first struck the banks of the larger pool. We had hitherto had, but poor spolt, so after dining on the remains of our fried fish and furinha, and smoking our cigarettes, the ap paratus for making which, including bamboo tinder-box and steel and flint for striking a light, being carried by every one always on these expeditions, we made off in another (westerly) direction through the forest to try to find better huuting ground. We quenched our thirst with water from the pool, which I was ruther surprised to find quite pure. These pools are, of course, sometimes fouled for a time by the mnvements of alligators and other tenants in the fine mud which settles at the bottom, but I never observed a scum of confervæ or traces of oil revealing animal decomposition on the surface of these waters, nor was there ever any foul smell perceptible. The whole of this level land, instead of being covered with unwholesome swamps emitting malaria, forms in the dry season (and in the wet also) a most healthy country. How elaborate must be the natural processes of self-purification in these teeming waters !

On our fresh route we were obliged to cut our way through a long belt of bamboo un. derwood, and not being so careful of my steps as my companions, I trod repeatedly on the flinty thorns which had fallen from the bushes, finishing by hecoming completely lame, one thorn having entered deeply the sole of my fout. I was obliged to be left behind, Lino, the Indian, remaining with me. The careful fellow cleaned my wounds with 
his saliva, placed pieces of isca (the felt-like substance munufactured by ants) on them to stanch the blood, and bound my feet with tough bast to serve as shoes, which he cut from the bark of a Mongúba tree. He went about his work in a very gentle way and with much skill, but was so sparing of speech that I could scarcely get answers to the questions I put to him. When he had doue, I was able to limp about pretty uimbly. An Indian, when he performs a service of this kind, never thinks of a reward. I did not find so much disinterestedness in negro slaves or half-castes. We had to wait two hours for the return of our companions : during part of this time I was left quite alone, Lino having started off into the jungle after a peccary (a kind of wild hog) which had come neur to where we sat, but on seeing us had given a grunt and bounded off into the thickets. At length our friends hove in sight, loaded with game, having shot twelve curassows and two cujubíms (Penelope Pipile), a handsome black fowl with a white head, which is arboreal in its habits, like the rest of this group of gallinaceous birds inhabiting the South American forests. They had discovered a third pool contuining plenty of turtles. Lino rejoined us at the same time, having missed the peccary, but in compensetion shot a quandú, or porcupine. The mulatto boy had caught alive in the pool a most charming little water-fuwl, a species of grebe. It was somewhat smaller than a pigeon, and had a pointed beak; its feet were furnished with many intricate folds or frills of skin instead of webs, and resembled very much those of the gecko lizards. The bird was kept as a pet in Jabuti's house at Ega for a long time afterward, where it becamie accustomed to swim about in a common hand-basin full of water, and was a great favorite with everybody.

We now retraced cur steps toward the water-side, a weary walk of five or six miles, reaching our canve by half-past five o'clock or a little before sunset. It was considered by every one at Catuá that we had had an unusually good day's sport. I never knew any small party to take so much game in one day in these forests, over which animals are everywhere so widely and sparingly scattered. My companions were greatlv elated, and on approaching the encampment at Catuá made a great commotion with their paddles to announce their successful return. singing in their loudest key one of the wild choruses of the Amazonian boatmen.

The excavation of eggs and preparation of the oil being finished, we left Catuá on the 3d of November. Carepíra, who was now attached to Cardozo's party, had discovered another lake rich in turtles, about twelve miles distant, in one of his fishing rambles, and my friend resolved, before returning to Ega, to go there with his nets and drag it as we had formerly done the Aningal. Several mameluco families of Ega begged to accomvany us to share the labors and bouty : the
Shumána family also joined the party ; we therefore formed a large body, numbering in: all eight canoes and fifty persons.

The summer season was now breaking up : the river was rising; the sky was almost constantly clouded, and we had frequent rains. The mosquitoes also, which we had not felt while encamped on the sand-bunks now became troublesome. Fe paddled up the north-westerly channel, and arrived at a point near the upper end of Catjá at ten o'clock P.M. There was here a viry broad beach of untrodden white sand, which extended quite into the forest, where it formed rounded hills and hollows like sund-dunes. covered with a peculiar vegetation : harsh, reedy grasses, and low trees matted together with lianas, and varied with dwarf spiny palms of the genus Bactris. We encamped for the night on the sands, finding the place luckily free from mosquitoes. The different portions of the party made arched coverings with the toldos or maranta-leaf awnings of their canoes to sleep under, fixing the edges. in the sand. No one, however, seemed inclined to go to sleep, so after supper we all sat or lay around the large fires and amused. ourselves. We had the fiddler with us, and. in the intervals between the wretched tunes which he played, the usual amusement of story-telling beguiled the time-tales of hairbreadti escapes from jaguar, alligator, and so forth. There were among us a father and son who had been the actors, the previous year, in an alligator adventure on the edge of the praia we had just left. The son, while bathing, was seized by the thigh and carried under water; a cry was raised, and the father, rushing down the bank, plunged after the rapacious beast which was diving away with his victim. It seems almost incredible that a man could overtake and master the large cayman in his own element; but such was the case in this instance, for the animal. was reached and forced to release his booty by the man's thrusting his thumb into his eye. The lad showed us the marks of the alligator's teeth on his thigh. We sat up until past midnight listening to these stories und assisting the flow of talk by frequent potations of burned rum. A large shallow dish. was filled with the liquor and fired; when it. had burued for a few minutes the flame was. extinguished, and each one helped himself by dipping a tea-cup into the vessel.

One by one the penple dropped asleep und then the quiet murmur of talk of the few who remained awake was interrupted by the roar of jaguars in the jungle about a furlong. distant. There was not one only but severai of the animals. The older men showed considerable alarm and proceeded to light fresh fires around the outside of our encampment. 1 hao read in books of travels of tigers coming to warm themselves by the fires of a bivouac, and thought my strong wish to witness the same sight would have been grailfied to-night. I had not, however such good. fur tune, although I was the last to go to sleep, and $m y$ bed was the bare sand under a little. 
iarched covering open at both ends. The jaguars nevertheless must have come very near during the night, for their fresh footmarks were numerous within a score yards of the place where we slept. In the morning I had a ramble along the borders of the jun. gle, and found the tracks very numerous and close together on the saudy soil.

We remained in this neighborhood four days, and succeeded in obtaining many hundred turtles, but we were obliged to sleep two nights within the Carapanatúba channel. 'I'he first night passed rather pleasantly, fur the weather was fine, and we encamped in the furest, making large fires and slinging our hammocks between the trees. The second was one of the most miserable nights I ever spent. The air was close, and a drizzling rain began to fall about miduight, lasting until morning. We tried at first to brave it nut under the trees. Several very large fires were made, lighting up with ruddy g]eams the magnificent foliage in the black shades around our encampment. The heat and smoke had the desired effect of keeping off pretty well the mosquitoes, but the rain continued until at length everything was noaked, and we had no help for it but to bundle off to the canoes with drenched ham. mocks and garments. There was not nearly room enough in the flotilla to rccummodate so large a number of persons lying at full length ; moreover the night was pitch dark, and it was quite impossible in the gloom and confusion to get at a change of clothing. So there we lay, huddled together in the best way we could arrange ourselves, exhausted with fatigue and irritated beyond all conception by clouds of mosquitoes. I slept on a bench with a sail over me, my wet clothes clinging to my body, and to increase my discomfort, close beside me lay an Indian yirl, one of Cardozo's domestics, who had a skin disfigured with hlack disease patches, and whose thick clothing, not having been washed during the whole time we had been out (eighteen days), gave forth a most vile effuvium.

We spent the night of the 7 th of Norem. ber pleasuntly ou the smooth sunds, where the jaguars again serenaded us, and on the succeeding morning we commenced our return voyage to Egu. We first doubled the upper end of the Island of Catuá, and then struck off for the right bank of the Solimoens The river was here of immense width, and the current was so strong in the middle that it required the most strenuous exertions on the part of our paddlers to preveut us from being carried miles away down the stream. At night we reached the Juteca, a small river which enters the Solimoens by a chunnel so narrow that a man might almost jump across it, but a furlong inward - expands iuto a very pretty lake several niles in circumference. We slept again in the forest, and again were annoyed by rain and mosquitoes; but this time Cardozo and I preferred remaining where we were to mingling with the reeking crowd in the buats. When tive gray dawn arose, a steady rain was still fall. ing, and the whole sky had a settled leaden appearance, but it was delightfully cool. We took our net into the luke and gleaned $\mathrm{s}$ good supply of delicious fish for hreakfast. I saw at the upper end of this lake the native rice of this country growing wild.

The weather cleared up at 10 o'clock A.M. At 3 P.M. We arrived at the mouth of the Cayambé, another tributary stream much larger than the Juteca. The channel of exit to the Solimoens was here ulso very narrow, but the expanded river inside is of vast dimensions; it forms a lake (I may safely venture to say) several score miles in circum. ference. Although prepared for these surprises, I was quite taken aback in this case. We had been paddling all day along a monotonous shore, with the dreary Solimoens before us, here three to four miles broad, heavily rolling onward its muddy waters. We come to a little gap in the earthy banks, and find a dark, narrow inlet, with a wall of forest overshadowing it on each side; we enter it and at a distance of two or three hundred yards a glorious sheet of water bursts upon the view. The scenery of Cayambé is very picturesque. The land, on the two sides visible of the lake, is high and clothed with sombre woods, varied here and there with a whitewashed house in the middle of a green patch of clearing, belonging to settlers. In striking contrast to these dark rolling forests is the vivid light-green and cheerful foliage of the woods on the numer ous islets which rest like water-gardens ov the surface of the lake. Flocks of ducks, storks, und snow-white herons inhabit these islets, and a noise of parrots with the tingling chorus of Tamburi-parás was heard from them as we passed. This had a cheering effect, after the depressing stillness and absence of life in the woods on the margins of the main river.

Cardozo and I took a small boat and crossed the lake to visit one of the settlers, and on our return to our canoe, while in the middle of the lake, a squall suddenly arose, in the direction toward which we were going, so that for a whole hour we were in great dun. ger of being swamped. The wind blew away the uwning and mats, and lashed the waters into foam, the waves rising to a great height. Our boat, fortunately, was excellently constructed, rising well toward the prow, so that with good steering we managed to head the billows as they arose, and escapec without shipping much water. We reached our igarité at sunset, and then made all speed to Curubarú, fifteen miles distant, to encamp for the night on the sands. We reached the praia at ten o'clock. The waters were now mounting fast upon the sloping beach, and we found on dragging the net next morning that fish were beginning to be scarce Cardozo and his friends talked quite gloomilv at breakfast time. over the departure of the juyous verao, and the setting in of the dull, hungrv winter season.

At nine o'clock in the morning of the 10th 
of November a light wind from down river eyes. These red-faced apes belonged to an sprung up, and all who had sails hoisted species culled by the Indians Uakuri, which them. It was the first time during our trip is peculiar to the Ega district, and the cagethat we had had occasion to use our sails, with its contents was being sent as a present. so continual is the calm on this upper river. by Senhor Chrysostomo, the Director of ${ }^{-}$ We bowled along merrily, and soon entered Iudians of the Japurá, to one of the governthe broad channel lying between Bariá and meut ofticiuls at Rio Janeiro, in acknowledgthe mainland on the south bank. The wind ment of having been made colonel of the carried us right into the mouth of the Teffé, new Natiunal Guard. They had been ob. and at four o'clock P.M. we cast anchor in tained with great difflculty in the forests the port of Ega.

\section{CHAPTER XII.} which cover the lowlands, near the princinal mouth of the Jupurá, about thirty miles from Egr. It was the first time I had seen this most curious of all the South American monkeys, and one that appears to have escaped the notice of Spix and Martius. I

ANIMALS OF THE NEIGHBORHOOD OF EGA

Scarlet-faced Monkeys-Parauac6 Monkey-Owl-faced Night Apes-Marmosets-Jupnrd-Bats-Birds - Cuvier's Toucan-Curl-crested Toucan-Insects-Pendulous Cocoons-Foraging Ants-Blind Ants.

As may have been gathered from the remarks already made, the neighborhood of Ega was a fine field for a natural history collector. With the exception of what could be learned from the few specimens brought home, after transient visits, by Spix und Martius and the Count de Castelnau, whose acquisitions have been deposited in the public museums of Munich and Paris, very little was known in Europe of the animal tenants of this region. The collections that I had the opportunity of making and seuding hume attracter, therefore, cousiderabie attention. Indeed, the name of $\mathrm{my}$ favorite village has beceme yuite a houseliold word among a numerous class of naturalists, not only in England, but abroad, in consequence of the very large number of species (upward of 3,000 ) which they have bad to describe, with the locality "Ega" attached to them. The discovery of new species, however, forms but a small item in the interest belonging to the study of the living creation. The structure, habits, instincts, and geographical distribution of some of the oldestkuown forms supply inexhaustible materials for reflection. The few remarks I have to make on the animals of Ega will relate to the mammals, birds, and insects, and will sometimes apply to the productions o the entirely covered with hair, and of litle or whole Upper Amazons region. We will he- related to our Uakari huving it much shorter gin with the monkeys, the must interesting, thun usual. All the Cebidæ, both longnext to man, of all animals.

tailed and short-tailed, are equally dwellers

Scarlet-faced Monkeys. - Early one sunny in trees. The scarlet-faced munkey lives in morning, in the year 1855 , 1 saw in the furests which are inundated during great. streets of Eya a number of Indians, carrying part of the year, and is never known to de. on their shoulders down to the port, to be scend to the ground; the shortness of its: embarked on the Lpper Amazons steamer, a tail is therefore no sign of terrestrual liabits. large cage made of strong lianas, some as it is in the Macaques and Baboons of the twelve feet in length and five in height, con- Old World. It differs a little from the typitaining a dozen monkeys of the most gro- cal Cebidx in its teeth, the incisors being tesque appearance. Their bodies (about oblique and in the upper jaw cunverging, su eighteen inches in height, exclusive of limbs) as to leave a gap hetween the outermost and were clothed from neck to tail with very the cauine teeth. Like all the rest of its long, straight, and shining whitish hair; family, it differs from the monkeys of the their heads were nearly bald, owing to the Old World, and from man, in having an very short crop of thin giay hairs, and their additional grinding-tooth (premolar) on each saces glowed with the most vivid scarlet hue. side of both jaws, making the complete set. As a finish to their striking physiognomy, thirty-six insteud of thirty-two in number.

they had bushy whiskers of a sandy color, The white Uakari (Brachyurus culrus), meeting under the chin, and reddish-vellow seems to be found in no other part of: 
America than the district just mentioned, namely, the banks of the Japurá, neur its principal mouth ; and even there it is conined, as fur as I could learn, to the western side of the river. It lives in small troops among the crowns of the lofty trees subsisting on fruits of various kinds. Hunters say it is pretty nimble in its motions, but is not much given to leaping, preferring to run up and down the larger boughs in truvelling from tice to tree. The mother, as in other species uf the monkey order, carries her young on lier back. Individuals are obtained alive by flooting them with the blow-pipe and arrow lipped with diluted Urarí poison. They run a considerable distance after being pierced, and it requires an experienced hunter to track them. He is considered the most expert who can keep pace with a wounded one and catch it in his arms when it falls exhausted. A pinch of salt, the antidote to the poison, is then put in its mouth, and the creature revives. The species is rare, even in the limited district which it inhabits. Senhor Chrysostomo sent six of his must skilful Indians, who were absent three weeks lefore they obtained the twelve specimens which formed his unique and princely gift. When an independent hunter obtains one, a lery high price (thirty to forty milreis*) is for presents to persons of influcince down the for pres.

Adult Uakalis, caught in the way just described, very rarely become tame. They are peevish and sulky, resisting all attempts to coax them, and biting any one. who ven. tures within reach. They have no particular cry, even when in their native woods; in captivity they are quite silent. In the course of a few days or weeks, if not very carefully attendod to, they full into a listless cundition, refuse food, and die. Many of them succumb to a diseare which I suppose from the symptoms to be intlanmation of the chest or lungs. The one which I kept as a pet died of this disorder, ufter I had had It about three weeks. It lost its appetite in a very few days, although kept in an airy veranda; its coat, which was originally long, smooth, and glossy, became dingy and ragged, like that of the specimens seen in museums, and the bright scarlet color of its face changed to a duller hue. This color, in health, is spread over the features up to the rocts of the hair on the forehead and temples, and down to the neck, including the flabby cheeks, which hang down below the jaws. The animal in this condition looks at a short distance as though some one had laid a thick cont of red paint on its countenance. The death of $\mathrm{my}$ pet was slow ; duing the last twenty-four hours it lay prostrate, breathing quickly, its chest strcngly heaving; the color of its face became gradually paler, but was still red when it expired. As the hue did not quite disap-

* Three ponuds seven shillings to four pounds thir teen shillinge. pear until two or three hours after the animal was quite dead, 1 judged that it was not exclusively due to the blood, but partly, to a pigment beneath the skin, which would probably retain its color a short time after the circulation had ceased.

After seeing much of the morose disposition of the Uakarí, I was not a little surprised one day at a friend's house to find an extremely lively and familiar individual of this species. It ran from an inuer chamber straight toward me, after I had sat down on a chair, climbed my leys and nestled in my lap, turning round and looking up with the usual monkey's grin, after it had made itself comfortuble. It was a young animal which had been taken when its mother was shot with a poisoned arrow ; its teeth were incomplete, and the face was pale und mottled, the glowing scarlet bue not supervening in these animals before mature age ; it had also a few long black hairs on the eyebrows and lips. The frisky little fellow had been reared in the house umoug the childion, and allowed to run about freely, and take its meals with the rest of the household. There are few animals which the Brazilians of these villages have not succeeded in tamiug. I have even seen young jaguars rumning loose about a house, and ireated as pets. The animals that I had rarely becamse familiar, however long they might remain in my possession, a circumstance due no doutit to their being kept always tied up.

The Uakari is one of the many species of animals which are classified by the Brazilians as " mortál," or of delicate constitution, in contradistinction to those which are "duro," or hardy. A large proportinn of the specimens sent from Ega die before arriving at Pará, and scarcely one in a dozen succeeds in reaching R1o Janeiro alive. The difficulty it has of accommodating itself to changed conditions probably has some connection with the very limited range, or confined sphere of life, of the species in its natural state, its native lome beins an area of swamp! woods, not more than about sixty sque e miles in extent, although no permaner : barrier exists to check its dispersal, except toward the south, over a much wider space. When I descended the river in 1859, we had with us a tanue adult Uakarí, which was allowed to ramble about the vessel, a large schooner. When we reached the mouth of the Rio Negro, we had to wait four days while the custom-house officials at Barra, ten miles distant, made out the passports for our crew, and during this time the schooner lay close to the shore, with its bowsprit secured to the trees on the bank. Well, one morning, scarlet-face was missing having made his escape into that forest. Two men were sent in search of him, but returned after several hours' absence without having caught sight of the runaway. We gave up the monkey for lost, until the following day, when he reappeartil on the skirts of the forest, and march.। quir tly d , wa the bowsprit to his usual place 
on deck. He had evidently found the forests of the Rio Negro very different from those of the delta lands of the Japura and preferred captivity to freedom in a place that was so uncongenial to him.

The Parauacú Monkey. - Another Ega monkey, nearly related to the Uakarís, is the Parauacr (Pithecia hirsuta), a timid, inoffensire creature, with a long bear-like coat of harsh speckled-gray hair. The long fur hangs over the head, half concealing the pleasing diminutive face, and clothes also the tail to the tip, which mernber is well developed, being eighteen inches in length, or longer than the body. The Parauacu is found on the "terra firma" lands of the north shore of the Solimuens, from Tunantins to Peru. It exists also on the south side of the river, namely, on the banks of the Teffé, but there under a changed form, which differs a little from its type in colors. This form has been described by Dr. Gray as a distinct species, under the name of Pithecia albicans. The Parauacú is also a very delicate animal, rarely living many weeks in captivity; but any one who succeeds in keeping it alive for a month or two, gains in it a most affectionate pet. One of the specimens of Pithecia albicans nuw in the British Museum was, when living, the property of a young Frenchman, a neighbor of mine at Ega. It became so tame in the course of a few weeks, that it followed him about the streets like a dog. My friend was a tailor, and the little pet used to spend the greater part of the day seated on his shoulder while le was at work on his board. It showed, nevertheless, great dislike to stran. gers, and was not on good terms with any other member of my friend's huusehold than himself. I saw no monkey that showed so strong a personal attachment as this gentle, timid, sileut little creature. The eager and passionate Cebi seem to take the lead of all the South American monkeys in intelligence and docility, and the Coaita has perhaps the must gentle and impressible disposition ; but the Parauacu, although a dull, cheerless animal, excels all in this quality of capability of attachment to individuals of our own species. It is not wanting, however, in in. telligence us well as moral gondness, proof of which was furnished one day by an act of our little pet. My neighbor had quitted his house in the morning without taking Parauacú witu him, und the little creature having missed its friend, and concluded, us it seemed, that he would be sure to come to me, both being in the habit of paying me a daily visit together, came straight to $\mathrm{my}$ dwrlling, tuking a short cut over gardens, trees, and thickets, insterd of going the roundabuut way of the street. It had never done this before, and we knew the route it had taken only from a neighbor having watched its movements. On arriving at my house and not finding its master, it climbed to the top of my table, and sat with an air of quiet resignation, waiting for him. Shurtly afterward, my friend entered, and the gladdened pet then jumped to its usual peroh on his shoulder.

Orol-faced Night Apes.-A third interesting geuus of monkeys, found near Ega, are the Nyctipitheci, or Night Apes, called Ei-á by the Indians. Of these I found two species, closely related to each other, but nevertheless quite distinct, as both inhabit the same forests, namely, those of the higher and drier lands, without mingling with each other or intercrossing. They sleep all day lony in hollow trees, and come forth to prey on insects and eat fruits only in the night. They ure of small size, the body being about a foot long, and the tail fourteen inches, and ure thickly clothed with soft gray and brown fur, similar in substance to that of the rab. bit. Their physiognomy reminds one of the owl or tiger-cat ; the face is round and encircled by a ruff of whitish fur ; the muzzle is not at all prominent; the mouth and chin are small ; the ears are very short, scarcely appearing abuve the hair of the h:ad; and the eyes are large and yellowish in color, imparting the staring expression of nocturnal animals of prey. The forehead is whitish, and decorated with three black stripes, which in one of the species (Nyctipithecus trivirgatus) continue to the crown, and in the other (N. felinus) meet on the top of the forehead. $N$. trivirgatus wus first described by Humboldt, who discovered it on the banks of the Cassiquiare, near the head waters of the Rio Negro.

I kept a pet animal of the $N$. trivirgatus for muny months, a young one having been given to me by an Indian compadre, as a present from my newly-baptized godson. These monkeys, ulthough sleeping by day, are aroused by the least noise, so that when a person passes by a tree in which a number of them are concealed, he is startled by the sudden apparition of a group of little striped faces crowding a hole in the trunk. It was in this way that my compadre discovered the colony from which the one given to me was taken. I was obliged to keep my pet chained up; it therefore never became thoroughly familiar. I once saw, huwever, an individual of the other species (N. felinus) which was most amusingly tame. It was as lively and nimble as the Cebi, but not so mischievous and far more confiding in its disposition, delighting to be caressed by all persons who came into the house. But its owner, the Municipal Judge of Ega, Dr. Carlos Mariuna, had treated it for many weeks with the greatest kindness, allowing it to sleep with him at night in his hammock, and to nestle in his bosom half the day as he lay reading. It was a great favorite with every one, from the cleanliness of its habits and the prettiness of its features and ways. My own pet was kept in a box, in which was placed a broad-mouthed glass jar ; into this it would dive, head-foremost, when uny one entered the room, turning round inside. and thrusting forth its inyuisitive face an instant afterward to sture at the intruder. It was very active at night, venting at fro 
queut intervals a hoarse cry, like the sup- collector of birds and mammals, whom I emjressed barking of a dog, and scampering ployed, and who resided a long time among sbout the room, to the length of its tether, the Tucuna Indians, near Tubatinga, I calcuafter cockroaches and spiders. In climbing lated that one horde of this trihe, 200 in numbetween the box and the wall, it straddled ber, destroyed 1,200 of these moukeys annuthe space, resting its hands on the palms and ally for foud. The species is very numerous tips of the outstretched fingers, with the in the forests of the higher lands, but, owing knuckles bent at an acute angle, and thus to long persecution, it is now seldom seen in mounted to the top with the greatest facility. the neighborhood of the larger villages. It Although seeming to prefer insects, it ate is not found at all on the Lower A mazons. all kinds of fruit, but would not tcuch raw Its manners in captivity are grave, and its or cooked meat, and was very seldom thirsty. temper mild and confiding, like that of the I was told by persons who had kept these Coaitás. Owing to these traits, the Barrigudo monkeys loose about the house, that they is much suught after for pets; but it is not - leared the chambers of bats as well as insect hardy, like the Coaitás, und seldom survires vermin. When approached gently, my Ei-á a passage down the river to Purá

allowed itself to be caressed; but when Marmosets. - It now only remains to notice haudled roughly, it always took alarm, biting the Marmosets, which form the second family severely, striking out its little hands, and of American monkeys. Our old friend making a hissing noise like a cat. As al- Midas ursulus of Para and the Lower Ama. ready related, my pet was killed by a jealous zons is not found on the upper river, but in Ciiarára monkey, which was kept in the its stead a closely allied species presents it. house at the same time.

self, which appears to be the Midas rufoniger

Barrigudo Monkeys. - Ten other species of of Gervais, whose mouth is bordered with monkeys were found, in addition to those longish white hairs. The habits of this spealready mentioned, in the forests of the $\mathrm{Up}$ - cies are the saine as those of the $\mathrm{M}$. ursulus, per Amazons. All were stricly arboreal and indeed it seems probable thut it is a form cr diumal in their habits, and lived iu flocks, race of the same stock, modified to suit the travelling from tree to tree, the mothers with altered local conditions under which it lives. their childıen on their backs; leading, in One day, while walking along a forest pathfact, a life similar to that of the Parárauate way, I saw one of these lively little fellows Indians, and, like them, occasionally plun-miss his grasp as he was passing from one dering the plantations which lie near their tree to anuther along with his troop. He line of march. Some of them were found fell head-foremost from a height of at least also on the Lower Amazons, and huve been fifty feet, but managed cleverly to alight on noticed in former chapters of this narrative. his legs in the pathway; quickly turning Of the remainder, the most remurkable is the round, hu gave me a good stare for a few Macaco barıigudo, or big-bellied nonkey of moments, and then bounded off gayly to the Portuguese colonists, a species of Lagoth- climb another tree. At Tunantins 1 shot a ix. The genus is closely allied to the pair of very hantsome species of marmoset, Couitás, or spider monkeys, having, like the M. rufiventer, I believe, of zoologists. them, excecdingly strong and flexible tuils, Its coat was very glossy and smonth, the which are furnished underneath with a back deep brown, and the underside of the naked palm like a hand, for grasping. The body of rich black and reddish hues. A Barrigudos, however, are very bulky ani- third species (found at Tabating , 200 miles mals, while the spider monkeys are remark- further west) is of a deep black culor, with gble for the slenderness of their bodies and the exception of a patch of white hair around limbs. I obtained specimens of what have its mouth. The little auimal at a short disbeen considered two species, one ( $L$. oliva- tance looks as though it held a ball of snow. ctus of Spix ?) having the head clothed with white cotton in its teeth. The last I shall gray, the other (L. Humboldtii) with black mention is the Hapale pygmæus, one of the fur. They both live together in the same most diminutive furms of the monkey order, places, and are probably only differently col- three full-grown specimens of which, measurored individuals of one and the same species ing only seven inches in length of body, I I sent home a very large male of one of these obtained neatr St. Paulo. The pretty Lilikinds, which measured twents-seven inches putian face is furnished with lung brown in length of trunk, the tail being twenty-six whiskers, which are nuturully brushed back inches long; it was the largest menkey I over the ears. The general color of the anisaw in America. with the exception of a mal is bruwnish-tawny, but the tail is elebluck Howler, whose body was twenty.eight nches in height. The skin of the face in the Barrigudo is black and wrinkled, the forehead is low, with the eyebrows projecting, and, in short, the features altogether resemble in a striking manner thuse of an old negro. In the forests the Barrigudo is not a very active animal; it lives exclusively on fruits, and is much persecuted by the In. dians on account of the excellence of its flesb gantly barred with black. I was surprised on my return to Euyland to learn, frum speciwens in the British Museurn, that the pygmy marmoset was found also in Mexic !. no other Amazunian monkey being kuuwu tw wander fur from the great river plain. Thus the sinallest and apparently the feeblest species of the whole order is one which has by soure a a ans become the most widely dispersed.

The Jupura. - A curinus animal, knowa to $s_{\beta}$ fcod. From information griven me by 21 . Luturalists as the Kinkaiou 'mit salled Japuiá 
by the Indians of the Amazons, and considered by them as a kind of monkey, may be mentioned in this place. It is the Cercoleptes caudivolvus of zoologists, and has been considered by some authors as an intermediate furm between the Lemur family of apes and the pluntigrade Carnivoru, or bear family. It has decidedly no close relationship to either of the groups of American monkeys, having six cutting teeth to each jaw, and long claws instead of nails, with extremities of the usual shape of paws instead of hunds. Its muzzle is conical and pointed, like that of many lemurs of Madagascar ; the expression of its countenance, and its habits and actions, are also very similar to those of lemurs. Its tail is very tlexible toward the tip, and is used to twine round branches in climbing. I did not see or hear anvthing of this animal while residing on the Lower Amazons, but on the banks of the upper river, frum the Teffé to Peru, it appeared to be rather common. It is nocturnal in its habits, like the owl faced monkeys, although unlike them it has a bright, dark eye. I unce saw it in considerable numbers when un au excursion with an In. dian companion alung the li.w Y Yapó shores of the Teffé, about twent: miles ubove Ega. We slept one night at ine house of a native family living in the thick of the forest, where a festival was going on, and there being no
room to hang our hammocks under shelter, on account of the number of visitors, we lay duwn on a mat in the open air, near a shed the must harmless of all bats, and its inoffen. which stood in the midst of a grove of fruit sive character is well known to residents on trees and pupunha palms. Past midnight, the banks of the Amazons. I found two diswhen all becume still ufter the uproar of holi- tinct species of it, one having the fur of a day-making, as I was listening to the dull, blackish color, the other of a ruddy hue, and fanning sound made hy the wings of impish ascertained that both fced chiefly on fruits. hosts of vampire bats crowding round the The church at Ega was the headquarters of Cajú trees, a rustle commenced from the side both kin ts; I used to see them, us I sat at of the woods, and a troop of slender, lnng- my dous luring the short evening twilights, tailed animals were seen against the clear trooping iorth by scores from a large open moonlit sky, taking flying leaps from branch window st the back of the altar, twittering to branch throngh the grove. Muny of them cheerfully as they sped off to the borders of stopped at the pupuuha trees, and the the forest. They sometimes enter houses; hustling, twittering, and screaming, with the first time I saw one in my chamber, sounds of falling fruits, showed how they wheeling heavily round and round, I mistook were employed. I thought at first they were $1_{2}$ "or a pigeon, thinking that a tame one had Nyctipitheci, but they proved to be Jupurás, escaped from the premises of one of my for the owner of the house early next morn- neighbors. I opened the stomach of several ing, caught a young one, and gave it to me. of these bats, and found them to contain a I l.ept this as a pet animal for several weeks, mass of pulp and seeds of fruits, mingled fecding it on bananas and mandioca-meal with a few remains of insects. The natives mised with treacle. It became tame in a say they devour ripe cajús and guavas on very short time, allowing itself to be caressed, trees in the gardens, but on comparing the but making a distinction in the degree of seeds taken from their stomachs with those c.) afidence it sliowed between myself and of all cultivated trees of Ega, I found they st: augers. My pet was unfortunately killed were unlike any of them; it is therefore by a neighbor's dog, which entered the room probable that they generally resort to the forwhere it was kept. The animal is so difficult est to feed, coming to the village in the mornto obtain alive, its place of retreat in the day. ing to sleep, because they find it more secure tirse not being known to the natives, that I from animals of prey than their natural wis unable to procure a second living speci- abodes in the woods.

\section{man.}

Buts. - The only uther mainmals that I shall m.ntion are the bats, which exist in very censilemile numbers and variety in the for. to. as well us in the buildings of the villages.
Birds. - I have already had occasion to men. tion several of the more interesting birds. found in the Ega district. The first thing that would strike a new-comer in the forest of the 
Tpper Amaroms would be the general scarcity of birds;: indeed, it often happened that I did sout meet with s single bird during a whole days' ramblete in the richest and most valied jpart of the wood. Fet the countiy is tensanted by many hundred species, many of which are in reality abuudunt, and scme of them conspicuous from their brilliant plu. miage. The cause of their apparent sarity is to le sought in the sameness and density of the ith. usiand miles of forest which constitute their dwelling-place. The birds of the counit $y$ are gregarious, at least during the scasons wien they are mo:t readily found: but the t ugivorous kinds are to be met with only Then certain wild fruits are ripe, and to know the exact localities of the trees requires months of experience. It wiculd not be sup. posed that the insectivorcus binds are also yegarious; but they are so, numbers of distinct species, belc nging 10 many different families, joining legeller in the chase or serach of food. The prccerdings of these associated bands of iustct-1 unteis are not a l.tile curious, and mesit a fow romarks.

While hunting ale ng the nw row pathways That are made through the fores in the neighbol hond of bouses and villages, one may pass several days without seeing 'many bists; lut now and then the surrounding J ushes and trees appear suddenly to swarm " ith them. There are scoses, picbably hun. r?ieds, of birds, all moving aliout $w$ ith the ¿grealest activity - woodpeckers and Dendro"claptidæe (frcm species no lai ger than a spara $w$ to othes the size of a cr(w) Iunning up the tree trunks; tanagers, ant-lhrushes, hum ming-birds, fly-calchers, and basbets, flitting a lout the leaves and lower brunches. The 7 ustling crowd loses no tume, and although moving in cencert, each bird is occupied on jis CWn aocount in starching hat $k$ or leaf or Awig, the barbets visiting every clayey nest of termites on the tuces which lie in the lipe If march. In a $\mathrm{f}(\mathrm{w}$ minutes the host is cone, and the forest puth romains deserted and-silent as before. I became in course of time 80 accustrmed to this habit of birds in the ncods near Ega, that I could genesally find the flock of associated marauders when* ver I wanted it. There sppcared to he only a de of these flicks in erch mull district ; 2. ad as it traverser chiefly a limited tract of woods of efcond gicwith I used 10 try differat paths until I ce me up with it.

The Indians have neticed these miscelianecus 1 unting-rasties of bisds, but appear not to have olserved that they are occupied in searching for insects. They have supplied their want of knowlcdge, in the usual way if half-clvilized people, by a theory which has degenerated into a myth, to the effect that the onward moving hands are led by a little gray bird called the Uiıá-purá, which fasciuates all the rest, and leads $\mathrm{thc} \mathrm{m}$ a weary dance through the thickets. There is certainly ome appeurance of truth in this $\mathrm{ex}$. planation ; for \&c metimes stray birds encountered in the line of march are seen to be drawn jpto tpe throgg, and fusely fiugivor- ous hirds are now and then found mixed up with the rest, as though led away by some will-o'-the-wisp. The native wemen, even the white and half-caste iuhabitants of the towns, attach a superstitious value to the skin and feathers of the Uira-pará, believing that if they keep them in their clothes-chest the relics will have the effect of attracting for the happy possessors a train of lovers and followers. 'These birds' art en nseuuently in great demand in sume siaces iro jenters selling tbem at a $: \mathrm{ig}$ in price to the foolish girls, who preserve the bodies by drying flesh and feathers together in the sun. I could never get a sight of this famous little bild in the forest. I once employed Indians to obtain specimens for me; but after the same man (who was a noted woodsman) had brought me at different times three distinct species of birds as the Uirá-pará, I gave up the story as a piece of humbug. The sim. plest explanation appears to be this, that the birds associate in flocks from the instinct of - self-preservation, and in order to be a less easy prey to hawks, snakes, and other enemies, than they would be if feeding lone.

Toucans-Cuver's Toucan.-Of this fam. ily of birds, so conspicuous from the great size und light structure of their beaks, and so characteristic of trupical American foresis, five species inhabit the woods of Ega. The commonest is Cuvier's Toucan, a large bird, distiuguished from its nearest relatıves by the fenthers at the bottom of the back being of a saffron hue instead of red. It is found more or less numerously throughout the year, as it breeds in the neighborhood, laying its eggs in holes of trees at a great height from the ground. During most months of the year it is met with in single individuals or small flocks, und the birds are then very wary. Sumetimes one of these little bands of four or five is seen perched for hours tugether among the topmost branches of high trees, giviug vent to their remarkably loud, shrill, yelping cries, one bird mounted higher than the rest, acting apparently as leader of the inharmonious chorus ; but two of them are often heard yelping alternately and in different notes. These cries have a vague resemblance to the syllables Tocán', Tocáno, and hence the Indian name of this gevas of birds. At these times it is difticult to get a shot at Toucans, for their senses are so sharpened that they descry the hunter before he gets near the tree on which they are perched, although he may be half concealed among the underwood 150 feet below them. They stretch their necks downward to look benenth, and on espying the least movement among the foliage, tly off to the more inaccessible parts of the forest. Solitary Tuucuns are sometimes met with at the samo season, hopping silently up and down the larger boughs, and $p$ eriug into the crevices of tree trunks. They moult in the months from March to Jun", some individuals earlier, others later. This season of euforọed quiet being passed, they makse 
their appearance suddenly in the dry forest near Ega, in large flucks, probably assemblages of birds gathered together from the neighboring Ygapó forests, which are then flonder and cold. The birds have now become sxceedingly tame, and the troups travel with heavy laborious flight from bough to bongh ainong the lower trees. They thus become an easy prey to hunters, and every one ut Ega who can get a gun of any sort and a few eharges of powder and shot, or a blow-pipe, goes daily to the woods to kill a few brace for dinner ; for, as already observed, the people of Ega live almost exclusively on stewed and roasted Toucans duing the months of June and July, the birds being then very fat, and the meat exceelingly sweet and tender.

No one on secing a Toucan can help asking what is the use of the enormous bill, which, in some species, attains a length of seven inches, and a width of more than two inches. A few remarks on this subject may be here introduced. The early naturalists having seen only the bill of a Toucan, which was esteemed as a marvellous production by the virtuosi of the sixteenth and seventeenth centuries, concluded that the bird must have belonged to the aquatic and web-footed order, as this contains so many species of remarkable development of beak, adapted for seizing fish. Some travelers also related fabulous stories of Toucans resorting to the banks of rivers to feed un fish, and these accounts also encouraged the erroneous views of the habits of the birds which for a long time prevailed. Toucans, however, are now well known to be eminently arboreal birds, and to belong to a group (including trogons, parrots, and barbets ), all of whose members are fruit-eaters. On the Amazons, where these birds are very common, no one pretends ever to have seen a Toucan walking on the ground in its vatural state, much less acting the part of a swimming or wading bird. Professor Owen found, on dissection, that the gizzard in Toucans is not so well adapted for the trituration of food as it is in other vegetable feeders, and concluded, therefore, as Bruderip had observed the habit of chewing the cud in a tame bird, that the great toothed bill was useful in holding andre-masticating the food. The bill can scarcely be said to be a very good contriv. ance for seizing and erushing small birds, or taking them from their nests in crevices of trees, habits which have been imputed to Tuucans by some writers. The hollow, cellular structure of the interior of the bill, its curved and clumsy shape, and the deficiency of force and precision when it is used to seize objects, suggest a want of fitness, if this be the function of the member. But fruit is undoubtedly the chief food of Tuucans, and it is in reference to their mode of chtaining it that the use of their uncouth bills is $t o$ be songbt.

Flowers and fruit on the crowns of the lurge trees of South American forests grow principally toward the end of slender twigs which will not bear any considerable wight; all anim:tls, therefore, which feed upon food, or on iusects contained in flowers, must, of course, hare some means of reaching theends of the stalks from a distance. Monke y: obtain their food by stretching forth the ir long arms, and, in some instances, their tails, to bring the fruit near to their mouths. Humming-birds are endowed with highly. perfected organs of flight, with corresponding muscular derelopment, by which they are enabled to sustain themselves on the wivg. before blossoms while rifling them of their contents. These strong-flying creatures, however, will, whenever they can get near enough, remain on their perches while prob. ing veighboring flowers for insects. Trogons have feeble wings, and a dull, inactive temperament. Their mode of obtaining foud is to station themselves quietly on low branches in the gloomy shades of the forest, and eye the fruits on the surrounding trees, darting: off as if with an effort every time they wish to seize a mouthful, and returning to the same perch. Barbets (Cupitoninæ) seem to have no especial enduwment, either of habits or structure, to enable them to seize fruits : and in this respect they are similar to the Toucans, if we leave the bill out of question, both tribes having heavy bodies, with feeble oryans of flight, so that they are disabled from taking their food on the wing. The purpose of the enormous bill here becomes evident. It is to enable the Toucan to reach and devour fruit while remaining seated and thus to counterbalance the disadvantage which its heary body and gluttonous appetite would otherwise give it in the conıpetition with allied groups of birds. The relation between the extraordinarily lengthened bill of the Toucan and its mode of obtaining food, is therefore precisely similar to that between the long neck and lips of the Giraffe and the mode of browsing of the animal. The bill of the Toucan can scurcely be cunsidered a very perfectly-formed instrument for the end to which it is applied, as here explained; but nature appears not to invent organs at once for the functions to which. they are now adapted, but avails herself, here of one already-existing structure or instinct, there of another, according as they are handy when need for their further modification arises.

One day while walking along the principal pathway in the woods near Ega, I saw one of these Toucans seated gravely on a luw branch close to the road, and had no difficulty in seizing it with my hand. It turned out to be a runaway pet bird; no one, however, came to own it, although I kept it in my hnuse fur several months. The bird was in a half-starved and sickly condition, but after if few days of good living it recovered health and spirits, and became one of the must. amusing pets imaginable. Many excellent: accounts of the habits of tame Trucans have been published, and therefore I need nut de. scribe them in detail, but I do not recollect to have seen any uotice of their intelligence 
and confiding disposition under domestica. tivn, in which qualities my pet seemed to be almust equal to parrots. I allowed Tocáno to go free about the house, cuntrary to my usual practice with pet animals; he never, however, mounted my working tuble after a ismart correction which he received the first time he did so. He used to sleep on the top of a box in a corner of the ronm, in the usual position of these birds, namely, with the long tail laid right over on the back, and the beak thrust underneath the wing. He ate of everything that we eat, beef, turtle, fish, farinlia, fiuit. and was a constunt attendant at our talle-a cloth spread on a mat. His uppetite was most raveuous, and his powers of digestion quite wonderful. He got to know the meal hours to a nicety, and we found it very difficult, after the first wiek or two, to keep him away from the dining-room, whero he had become very impudent and tronble:some. We tried to shut him out by inclosing him in the back yaid, which was separated by a high fence from the strcet on which our front door opened, but he used to climb the feuce and hop round by a long cir. cuit to the dining-room, making his appearance with the greatest puncluality us the meal was placed on the table. He acquired the habit afterward of rambling about the street near our house, and one day he was stolen, so we gave him up for lost. But two days afterwurd he stepped through the open doorway at dinner-hour, with his old gait :and sly, magpie-like expression, having escaped from the house where he had been guarded by the person who had stulen him, and which was situated at the further end of the village.

The Curl-crested Toucan (1-ieroglossus Beau. harnaisii). - Of the four sinaller Toucans, or Arassaris, found near Ega, the Pteroglossus flavirostris is perhaps the nust beautiful in -colors, its breast being adorued with broad helts of rich crimson and black; but the imost curious species hy far is the Curl-crested, or Beautiarnais Tosucun. The feathers $n n$ the head of this siogular bird are transformed into thin horny plates, of a lustrous black color. curled up at the ends, and resembling shavings of steel or ebony wood, the curly clest being arranged on the crown in the form of a wig. Mr. Wallace ;and I fitst met with this species on ascending ithe Amazons, at the mouth of the Solimoens ; from that point it continues as a rather commun bird on the ters firma, at least on the south side of the river, as far as Fonte Bwa, but I did not hear of its being found further to the west It appears in large flocks in the forests near Ega in May and June, when it has completed its moult. I did not find these bands congregated at fruit trees, but always wandering through the forest, hupping from branch 10 branch among the lower trees, and partly cuncealed among the foliuge. None of the Arassaris $10 \mathrm{my}$ knowledge make a yelping noise like that attered by the larger Trucuns (Ramphastos) the notes of the cu.l-crested species are very singular, resembling the croaking of frogs. I had an amusing adventure one day with these hirds. I had shot one from a rather high tree in a dark gleu in the forest, and en. tered the thicket where the bird had fallen to secure my booty. It was only wounded, and on my attempting to seize it, set up a loud screain. In an instant, as if by magic, the shady nook seemed alive with these birds, ulthough there was certainly none visible winen I entered the jungle. They de. sceuded toward me, hopping from bough to bough, some of them swinging on the loops and cables of woody lianus, and all croaking and fluttering their wings like so many furies. If 1 had had a long stick in my hand, I could have knocked several of them over. After killiug the wounded one, I be. gan to prepare for obtaining more specimens and punishing the viragoes for their boldness ; but the screaming of their companion having ceased, they remounted the trees, and befory I could reload every one of them had disappeared.

Insects. - Upward of 7000 species of insects were found in the neighborhood of Ega. I must cunfine myself in this place to a few remarks on the order Lepidoptera, and on the ants, several kinds of which, found chietly on the Upper Amazons, exhibit the most extraordin:sry instincts.

I found about 550 distinct species of butterflies at Eya. Those who know a little of Entumology will be able to form sume idea if the riches of the place in this department when I inention that eighteen species of true papilio (the swallow-tail genus) were found witbin ten ininutes' walk of my house. No fact could speak more plainly for the surpassing exuberance of the vegetation, the varied nature of the land, the perennial warmth and humidity of the climate. But no description can convey an adequate notion of the beauty and diversity in form and color of this class of insects in the neighborhood of Ega. I paid especial attention to them, having found that this tribe was better adupted than almost any other group of animals or plants, to furnish facts in illustration of the nislifications which ail species undergo in nature under clianged local conditions. This accidental superiority is owing partly to the simplicity and distinctness of the specific characters of the insects, and partly to the facility with which very copious series of specimens can be collected and placed sido by side for comparisor. The distinctuess of the speciflc characters is dine prohably to the fact that all the superficial signs of change in the organization are exaygerated and mude unusually plain by affecting the framework, shape, and color of the winge, which, as many anatomists believe, are magnified extensions of the skin around the breathing orifices of the thorax of the insects. These expansions are clothed with minute feathers or scales, colored in regular patterns, which vary in accordance with the slightest chunge in tho conditions to which the species uro us- 
posed. It may be said, therefore, that on these expanded membranes nature writes, as on a tablet, the story of the modifications of species, so truly do all changes of the organization register themselves thereon. Moreover, the same color-patterns of the wings geuerally show, with great regularity, the degrees of blood relationship of the species. As the laws of vature must be the same for. all beings, the conclusions furnished by this group of insects must be applicable to the whole organic world ; therefore the study of butterflies-creatures selected as the types of uiriness and frivolity - instead of being despised, will some day be valued as one of the most important branches of biological science.

Before proceeding to deseribe the ants, a few remarks may be made on the singular cases and cocoons woven by the caterpillars of certain moths found at Ega. The first that may be mentioned is one of the most habits has been given in the first chapter of beautiful examples of insect workmanship I this work. The Satiba is a vegetuble feeder, ever saw. It is a cocoon, ulout the size of and does not attack other animals; the ac4 sparrow's egg, woven hr a caterpillar in counts that have been published regarding broad ineshes of either buff or rose-colored carnivorous ants which bunt in vast armies, silk, and is frequently seen in the narrow exciting terror wherever they go, apply unly alleys of the forest, suspended from the ex- to the Ecitons, or foraging ants, a totally diftreme tip of an outstanding leaf by a strong therent group of this tribe of insect3. The silken thread five or sis inches in length. It Ecitons are called Tauóca by the Indians, torms a very conspicuous object, hanging who are always on the lookout for their thus in mid-air. The glossy threads with armies when they traverse the forest, so as which it is knitted are stıut, and the structure to avoid being attacked. I met with ten disis therefore not liable to be torn by the beaks tinct species of them, nearly all of which of insectivorous birds, while its pendulous bave a different system of marching; eight position makes it duubly secure against their were new to science when 1 sent them to attacks, the apparatus giving way when they peck ut it. There is a small orifice at each end of the egg-shaped bag, to admit of the escape of the moth when it changes from the - little chrysalis which sleeps tranquilly in its aury cage. The moth is of a dull slaty color, and belongs to the Lithosiide groupe of the silk-worm family (Bombycidæ). When the caterpillar begins its work, it lets itself down from the tip of the leaf which it has chosen, by spinning a thread of silk, the thickness of which it slowly increases as it descends. Having given the proper length to the cord, it proceeds to weave its elegant bag, placing itself in the centre and spinning rings of silk at regular intervals, connecting them at the same time, by means of cross-threads; so that the whule, when finished, forms a loose web. with quadrangular meshes of nearly equal size throughout. The task occupies about fuur days. When finished, the enclosed caterpillar becomes sluggish, its skin shrivels and cracks, and there then remains a motiouless chrysalis of narrow shape, leaning against the sides of its silken cage.

Many other kinds are found at Ega bo longing to the sume cocoon-weaving family, some of which differ from the rest in theil caterpillars possessing the art of fabricating cases with fragments of wood or leaves, in which they li re secure from all enemies while they are feeding and growing. I saw many sperics of these; some of them knitted together, with fine silken threads, small bits $\mathfrak{f}$ stick, and so made tubes similai to those of caddice-worms ; others (Saccophora) chrose them an elongated bag open at both ends, and having the inside lined with a thick web. The tubes of full-grown caterpillars of Sac. this stage of growth that I have generally seen them. They feed on the leaves of Melastomæ, and as in crawling the weight the contained caterpillar could sustain, the insect attaches the case, by one or more Foraging Ants. - Many confused statements have been published in books of travel and copied in natural history works regarding. these ants, which appear to have been conEngland. Some are found commonly in every part of the country, and one is peculiar to the open campos of Santarem; but. as nearly all the species are found together at Ega, where the forest swarmed with their armies, I have left an account of the habits of the whole genus for this part of my narra. tive. The Ecitons resemble in their habits the Driver ants of tropical Africa ; but thes have no close relationship with them is structure, and indeed belong to quite another sub-group of the ant tribe.

Like many other ants, the communities of Ecitons are composed, besides males aad females, of two classes of workers, a laryeheaded (worker-mujor) and a small-headed (worker-minor) class ; the large-heads have in some spceies greatly lengthened jaws, the small-heads have jaws always of the ordinaly shape; but the two classes are not sharpiy defined in structure and function, excent in two of the species. There is in all of them a little difference among the workers regaid. ing the size of the head; but in same species this is not sufficient to cause a separation into classes, with division of labor ; in uthers the jaws are so monstrously lengthened in the worker-majors, that they are incapacitated for taking part in the labors which the worker-minors perform; and again, in others the difference is so great that the distinction of classes becomes complete, one cting the part of soldiers, and the other that $f$ workers. The peculiar featuie in the 
Sabits of the Eciton genus is their hunting sur prey in regular bodies or armies. It is this which chiefly distinguishes ther firom the genus of common red stinging ants, sev. er al species of which inhabit England, whose liabit is to search for fond in the usual irregudar manner. All the Ecitons hunt in large, a rganized bodies; but almust every species has its own special manner of hunting.

Eciton rapax. - One of the foragers, Eciton tupax, the giant of its genus, whose wurkermajors are half an inch in length, hunts in single file through the forest. There is no division into classes among its workers, silthough the difference in size is very great. some being scarcely one half the length of (thers. The head and jaws, however, are always of the same shape, aud a grudation in t ze is presented from the lasgest to the fmallest, so that all are able to take part in the common labors of the colony. The chief employment of the species seems to be plunrering the nests of a large and defenceless unt of unother genus (Formica), whose man. gled bodies I have often seen in thair possession as they were marching away. The almies of Eciton rapax are never very nu. inero:is.

Eciton legionis.-Another species, E. legionis, ngrees with. E. rapax in having a orkers not rigidly divisible into two claseses; but it is much smaller in size, not differing areally in this respect from our common English red ant (Myımica rubra), which it also resembles in color. The Eciton legicnis ives in open places, and was seen only on ihe sandy campos of Santarem. The movenents of its hosts were, therefore, much more easy to observe than those $\mathrm{c} f$ all other kinds, $w$ hich inhabit solely the densest thickets; its stiug and bite also were less formidable than those of other species. The armies of $\mathbf{E}$. lejionis consist of many thousands of indipiduals, and muve in ruther broad columns. They are just as quick to break line on being disturbed, and attuck hurriedly und furiously any iutruding object, as the uther Ecitous. The species is not a common onc, and I seldom had good opportunities of watching its halits. The first time I saw an army was one evening near sunset. The columu consisted of two trains of unts, moving in epposite directions : one train empty-handed, the other laden with the mangled remains of insects, chiefly larvæ and pupæ of other ants. I had no difficulty in tracing the line to the sI ot from which they were conveying their tooty; this was a low thicket; the Ecitons were moving rapidly about a heap of dead leaves; but us the short tropical twilight was deepening rapidly, and I bad no wish to be benighted on the lonely campos, I deferred further examination until the nexi day.

On the following moruing no trace of ants could be found near the place where I had seen them the preceding day, nor were there signs of insects of auy description in the thicket ; but at the distance of eighty or one bindred yards, I came upon the samio army, engaged evidently on a razzia of a similar kind to that of the previous evening, but requiring othe: resources of their instinct, owing to the nature of the ground. They were eagerly occupied on the face of an inclined bank of light earth in excavating mines, whence, froin a depth of eight or ten inches, they were extracting the bodies of a bulky species of aut of the genus Formica. It was curious to see them criswding round the orifices of the mines, some assistiny their comrades to lift out the bodies of the Formicæ, and others tearing them in pieces, on account of their weight being too great for a single Eciton, a number of carriers seizing each a fragment and carrying it off down the slupe. On digging into the earth with a small trowel near the entrance of the mines, I found the nests of the Formicæ, with grubs and cocoons, which the Ecitons were thus invading, at a depth of absut eight inches from the surface. The eager freebooters rushed in as fast as I excavated, and seized the ants in my fingers as I picked them out, so that I had some difficulty in rescuing a few entire for specimens. In digging $i, s$ numerous mines to get at their prey, the in. tle Eeitons seemed to be divided into pirties, one set excavating and another set carrying away the grains of earth. When the shafts became rather deep, the mining parties had to climb up the sides each time they wished to cast out a pellet of eurth ; but their work was lightened for thein by comrades, who stationed themselves at the mouth of the shaft, and relievel them of their burdens, carryiny the particles, with an appearance of foresight which quite staggered me, a sufficient distance from the edge of the hole to prevent them from rolling in again. All the work seemed thus to be performed by intelligent co-operation amung the host of eager little creatures; but still there was not a rigid division of labor, for some of them, whose proceedings I watched, acted at one time as carriers of pellets, and at another as miners, and all shortly afterward assumed the office of conveyers of the spoil.

In about two hours all the nests of Formic: were rifled, though not completely, of their contents, and I turned toward the army of Ecitons, which were carrying away the mutilated remains. For sume distance there were many separate lines of them moving along the slope of the bank ; but a short distance off these all cunverged, and then formed one close aud broad column, which continued for some sixty or seventy yards, and terminated at one of those large termitariums or hillocks of white ants which are constructed of cemented material as hard as stone. The broad and compact column of ants moved up the steep sides of the hillock in a continued stream; many which had bitherto trotted along empty.handed, now turned to ussist their comrades with their heavy loads, and the whole descended into a spacious gallery or mice opening on the top of the termitarium. I did not try to reach the nest which 
I supposed to lie at the bottom of the broad mine, and therefore in the middle of the base of the stony hillock.

Eciton drepanophora. - The commonest species of foraging ants are the Eciton hamata and E. drepanophora, two kinds which resemble each other so clusely that it requires attentive examination to distinguish them; yet their armies never intermingle, ulthough moving in the same wools and often crossing each other's tracks. The two classes of workers look, at first sight, quite distinct, on account of the wonderful amount of difference between the largest individuals of the one, and the smallest of the other. There are dwarfs not more than one fifth of an inch in length, with small heads and jaws, and giants half an inch in length, with monstrously enlarged head and jaws, all belunging to the same broud. There is not, however, a distinct separation of classes, individuals existing which connect together the two extremes. These Ecitons are seen in the pathways of the torest at all places on the banks of the Amazons, traveling in dense columns of countless thuusancis. One or other of them is sure to be met with in a woodland ramble, and it is to them, probably, that the stories we read in buoks on South America apply, of ants clearing houses of vermin, although I beard of no instance of their entering houses, their ravages being confined to the thickest parts of the forest.

When the pedestrian falls in with a train of these unts, the first sigual given him is a twittering and restless movement of small flocks of plain-colored birds (ant thrushes) in the jungle. If this be disregarded until he advances a few steps farther, he is sure to fall into trouble, und find himself suddenly attacked by numbers of the ferocious little creatures. They swarm up his legs with incredible rapidity, each one driving its pincerlike jaws into his skin, and with the purchase thus obtained, doubling in its tail and stinging with all its might. There is ns course left but to run for it; if he is accompanied by natives, they will be sure to give the alarm, crying, "Tuuóca l" and scampering at full speed to the other end of the column of ants. The teuacious insects who have secured. them:elves to his legs then have to be plucked off one by one, a task which is generally not accomplished without pulling them in twain, and leaving heads and jaws sticking in the wounds.

The errand of the vast ant-armies is plunder, as in the cohmn, der, as in the case of Eciton legionis ; but which were running rearward, trotting along from their moving always among dense for a short distance, and then turning agrin. thickets their proceedings are not so easy to to follow the same cuurse as the main body. observe as in that species. Wherever they But these rearward movements were going move, the whole animal world is set in coin- on continually from one end to the other of motion, and every creature tries to get out of the line, and there was every appearance of their way. But it is especially the various this heing a meaus of keeping up a common tribes of winged insects that have cause for understanding among all the members of the fear, such as heavy bodied spiders, ants of army, for the retrograding ants stopped very other species, maggots, caterpillars, larræ of often for a moment to touch one or other of cuckroaches, and so forth, all of which live their onward-moving comrades with their under fallen leaves, or in decaying wood. antennæ, a proceeding which has been noThe Ecitons do not mount very high on. ticed in other ants, and sunposed to be their 
mode of conveying intelligence. When I interfered with the column or abstracted an individual from it, news of the disturbance was very quickly communicated to a distance of several yards toward the rear, and the column at that point commenced retreating. All the small-headed workers carried in their jaws a little cluster of white maggots, which I thought at the time might be young larvæ of their own colony, but afterward found reason to conclude were the grubs of some uther species whose nests they had been plundering, the procession being most likely not a migration, but a column on a marauding expedition.

The position of the large-headed individuals in the marching column was rather curious. There was one of these extraordinary fellows to about a score of the smaller class; none of them carried anything in their mouths, but all trotted along empty-handed and outside of the column, at pretty regular intervals from each other, like subaltern offcers in a marching regiment of soldiers. It was easy to be tolerably exact in this observation, for their shining white heads made them very conspicuous among the rest, bobbing up and down as the column passed over the inequalities of the road. I did not see them change their position or take any notice of their small-headed comrades marching in the column, and when I disturbed the line they did not prance forth or show fight so cagerly as the others. These large-headed members of the community have been considered by some authors as a soldier class, like the similarly-armed caste in Termites; but I found no proof of this, at least in the present species, as they always seemed to he rather less pugnacious than the workerminurs, and their distorted jaws disabled them from mstening on a plane surface like the skin of an attacking animal. I am in. clined, however, to think that they may act, in a less direct way, as protectors of the community, namely, as indigestible morsels to the flocks of ant-thrushes which follow the marching columns of these Ecitons, and are the most formidable enemies of the species. It is possible that the hooked and twisted jaws of the large-headed class may be effeclive weapons of annoyance when in the gizzards or stomachs of these birds, but I unfortunately omitted to ascertain whether this was really the fact.

The life of these Ecitons is not all work, for I frequently saw them very leisurely em. ployed in a way that looked like recreation. When this happened, the place was always a sunuy nook in the furest. The main colum? of the army and the branch columns, at these times, were in their ordinary relative posi. tious; but instead of pressing forward eager. $l y$, and plundering right and left, they seemed to have been all smitten with a sud. den fit of laziness. Some were walking slowly about, others were brushing their antennæ with their fure feet; but the drollest sight was their cleaning one another. Here and there an ant was seen stretching forth first one leg and then another, to be brushed and washe by one or more of its comrades, who performed the task by passing the limb between the jaws and the tongue, finishing by giving the antennæ a friendly wipe. It was a curions spectacle, and one well calculated to increase one's amazement at the similarity between the instinctive actions of ants and the acts of rational beings, a similarity which must have been brought about by two different processes of development of the primary qualities of mind. The actions of these ants looked like simple indulgence in idle amusement. Have these little creatures, then, an excess of energy beyond what is required for labors absolutely necessary to the welfare of their species, and do they thus expend it in mere sportiveness, like young lambs or kittens, or in idle whims like rational beings? It is probable that these hours of relaxation and cleaning may be in. dispensable to the effective performance of their harder labors; but while looking at them, the conclusion that the ants were engaged merely in play was irresistible

Eciton prodator. - This is a small dark-reddish species, very similar to the common red stinging ant of England. It differs from all other Ecitons in its habit of hunting, not in columns, but in deuse phalanxes consisting of myriads of individuads, and was first met with at Eya, where it is very common. Nothing in insect movements is more striking than the rapid march of these large and compact bodies. Wherever they pass, all the rest of the animal world is thrown into a state of alarm. They stream along the ground and climb to the summits of all the lower trees, searching every leaf to its apex, and whenever they encounter a mass of decaying vegetable matter, where hooty is plentiful, they concentrate, like other Ecitons, all their forces upon it, the dense phalanx of shining and quickly-moving bodies, as it spreads over the surface, looking like a flood of dark-red liquid. They soon penetrate every part of the confusod heap, and then, gathering together again in marching order, unward they move. All soft-bodied and inactive insects fall an easy prey to them, and, like other Ecitons, they tear their victims in pieces for facility of carriuge. A phalanx of this species, when passing over a tract of smooth ground, occupies a spaco of from four to six square yards; on examining the ants closely they are seen to move, not altogether in one straightforward direction, but in variously spreading contiguous columns, now separating a little from the general mass, now reuniting with it. The margins of the phalanx spread out at times like a cloud of skirmishers from the flanks of an army. I was never able to find the hive of this species.

Blind Ecitons. - I will now give a short account of the blind species of Eciton. None of the foregoing kinds have eyes of the fucetted or compound structure, such as are usial in insects, and which ordinary unts (Furmica) are furuished with, but all are provided with organs of vision composed each of a single
lens Connecting them with the utterly blind 
species of the genus, is a very stout-limbed Eciton, the E. crassicornis, whose eyes ale sunk in rather deep suckets. This ant goes on foraging expeditions, like the rest of its tribe, and attacks even the nests of other stinging species (Myrmica), but it avoids the light, always moving in concealment under leaves and fallen branches. When its columns have to cross a cleared space, the ants construct a temporary ccvered way with granules of earth, arched oper, and holding together mechanically; under this the procession passes in secret, the indefatigable creatures repairing their arcade us fast as breaches are made in it.

Next in order comes the Eciton vastator, which luas no eyes; although the collapsed sockets are plainly visible; and, lastly, the Eciton erratica, in which both sockets and eyes have disappeared, leaving only a faint ring to mark the place where they are usually situated. The armies of E. vastator and E. erratica move, as far as I could learn, wholly under covercd roads, the ants constructing them gradually but rapidly as they advance. The column of foragers pushes forward step by step under the protection of these cuvered passages, througl the thickets, and on reaching a rotting log or other promising hunting-ground, pour into the crevices in search of bonty. I have traced their arcades, occasionally, for a distance of one or two hundred yards; the grains of earth are taken from the soil over which the column is passing, and are fitted together without cement. It is this last-mentioned feature that distinguishes them from the similar covered roads made by Termites, who use their glutinous sali va to cement the grains together. The blind Ecitons, working in numbers, build up simultancously the sides of their convex arcades, and contrive, in a surprising manner, to approximate them and fit in the key-stones without letting the loose uncemented structure fall to pieces. There was a very clear division of labor between the two classes of neuters in these blind species. The large-heade 1 class, although not possessing monstrously leugthened jaws, like the worker-majors in $\mathrm{E}$. hamata and $\mathrm{E}$. drepanophora, are rigidly defined in structure from the small-headed class, and act as soldiers, defending the working community (like soldier Termites) against all comers. Whenever I made a breach in one of their covered ways, all the ants underneath were set in commotion, but the worker-minors remained behind to repair the damage, while the large-heads issued forth in a most menacing manuer, rearing their heads and snapping their jaws with an expression of the fiercest rage and defiance.

\section{CHAPTER XIII.}

\section{EXCURSIONS BEYOND EGA.}

Steamboat travelling on the Amazons-PassengersTunantins-Caishava Indians-The Jutahi-The Sap6-Marauá Indians-Foute Boa-Journey to St. Paulo - Tucúna Indians - Illness - Descent to Pará-Changes at Pará-Departure for Fngland.
November 7th, 1856. - Embarked on the Upper Amazons steamer, the Tabatinga. for an excursion to Tunantins, a small semi-In. dian settlement, Jying 240 iniles beyond Ega. The Tabatinga is an iron bout of about $1 \%$ tons burden, built at Rio de Janeiro, and fitted with engines of fifty-horse power. The saloon, with berths on each side for twenty passengers, is abure deck, and open at buth ends to admit a free current of air. The: captain or "commandante" was a licutenant. in the Brazilian navy, a man of pulished, sailor-like address, and rigid disciplinarian; his name, Senhor Nunes Mello Cardozo. I was obliged, as usual, to take witl me a stuck of all articles of food, except meat and fish, for the time I intended to be absent (three months) ; und the luggage, including hammocks, cooking utensils, crock. ery, and so forth, formed fifteen large packages. One bundle consisted of a mosquitotent, un article I had not yet had occasion to use on the river, but which was indispensable in all excursions beyond Eya, every persou, man. woman, and child, requiring one, as without it existence would be scarcely possible. My tent was about eight feet long and five feet bruad, and was made of coarse calico in an oblong shape, with sleeves at each end through which to pass the cords of a hammock. Under this shelter, which is fixed up every evening before sumiown, one can read and write, or swing in one's hammock during the long hours which intervene before bedtime, and feel one's sense of comfort increased by huving cheated the thirsty swarms of mosquitoes which fill the chamber.

Wo were four days on the road. The pilot, a mameluco of Ega, whom I knew very well, exhibited a knowledge of the river and powers of endurance which were quite remarkable. He stood all this time at his post, with the exception of three or four hours in the middle of each day, when he was relieved by a young mun who served as apprentice; and he knew the breadth and windings of the channel and the extent of all the yearly-shifting shoals from the Ric Negro to Lureto, a clistance of more than a thousand miles. There was no slackening of speed at night, except during the brief bit violent storms which occasionally broke upon us, und then the engiues were stopped by the command of Lieutenant Nunes, sometimes against the wish of the pilot. The nights were often so dark that we passengers on the poop deck could not discern the hardy fellow on the bridge; but the steamer drove on at full speed, men being stationed on the lookout at the prow, to watch for floating logs, and one man placed to pass orders to the helmsman; the keel scraped against a :and bank only nnce luring the passage.

The passengers were chiefly Peruvians, mostly thin, unxious, Yankee-looking men, who were returning home to the cities of Moyobamba and Chachapoyas, on the Andes, after a trading trip to the Brazilian towns on the Atlantic sea-board, whither they har gnne six months previously, with cargoes of 
Panama hats to exchange for Europeun wares. These hats were made of the young leaflets of a palm tree, by the Indiaus and alalf-caste people who inlabit the castern parts of Peru. They form almost the cnly urticle of export from Peru by way of the Amazons, but the money value is very great cumpared with the bulk of the goods, as the hats are generally of very fine quality, and cost from twelve shillings to six pounds sterling each; sone traders bring down two or three thousand pounds' worth, folded into small comp:iss in their trunks. The return cargoes consist of hardware, crockery, glass, and other bulkv or lieavy goods, but not of cloth, which, being of light weight, can be carried acros t the And?es from the ports on the Pacitic to the eastern parts of Peru. All kinds of Eurupean cluth can lse obtained at a much cheaper rate by this route than by the more direct way of the Amazons, the import duties of Peru being, as I was told, luwer than those of Brazil, and the difference not being counter balanced by increased expense of transit, un accinnt of weight, over the passes of the Aniles.

There was a great lack of amusement on board. The table was very well served, professed cooks being employed in these Amazonian steamers, and fresh meat insured by keeping on deck a supply of live bullocks and fowls, which are purchascd whenever there is an opportunity on the ruad. The river scenery was similar to that already described as presented between the Rio Negro and Ega; long reaches of similar aspect, with two long, low lines of forest, varied sometimes with cliffs of red clay, appearing Jne after the other, a horizon of water and sky on some days limiting the view buth up stream and down. We traveled, however, alway's near the bank, and, for my pait, I was never weary of admiring the picturesque grouping and variety of trees, and the valied mantles of creeping plants which clothed the green wall of forest every step of the way. With the exception of a small village called Fonte Boa, retire from the wain river, where we stopped to take in firewood, and of which I shall have to speak presently, we saw no human habitation the whole of the distance. The mornings were delightfully cool; coffee was served at sunrise, and a bountiful breakfast at ten o'clock; after that hour the heat rapidly increased until it became almust unbearable; how the enginedrivers and firenen stood it without exhaustion 1 cannot tell; it dininished after four o'clock in the afternoon, about which time dinner-bell rang, and the eveuings were always pleasant.

November 11 th to 30 th. - The Tunantins is a sluggish black-water stream, about sixty miles in length, and toward its mouth from 100 to 200 yards in breadth. The vegetation on its banks has a similar aspect to that of the Rio Negro, the trees having small foliage of a sombre hue, and the dark piles of greenery resting on the surface of the inky water. The village is situated on the left bank, about a mile from the mouth of the river, and cuntains tweuty liabitations, nearly all of which are merely hovels, built of lathwork and mud. The short streets, after rain, are alm ist impassable, on account of the many puddles, and are chnked up with weculs, leguminous shrubs, and scarlet-flowered asclepias. The atmosphere in such it place, hedged in as it is by the lofty forest. and surrounded by swamps, is always close, warm, and reeking ; and the hum und chirp of insects and birds cause a continual din. The small patch of weely yround around the. village swarms with piovers, saudpipers, striped herous, und scissor-tailed fiy-catchcrs ; and alligators are always seen fluating lazily on the surface of the river in front of the houses.

On landing, I presented inyse If to Senhur Panlo Bitancourt, a good-nitured half-caste, director of Indians of the neighboring river Íssá, who quickly ordered a small house to be cleared for me. This exhiluratiog abode contained on!y one room, the walls of which were disfigured by lurge and ugly patches of mud, the work of white ants. The flonr was the bare earth, dirty and damp; the wretched clıamber was darkened by a sheet of calico being stretched over the windows, a plan adopted here to keep out the Piumflies, which float about in all shady places like thin clouts of smuke, rendering all repuse inipsssible in the daytime whenever they cal. effect an entrance. My baggare was soon landed, and before the steamer departed I had taken gun, insect-net, and game bag, to make a prelininary exploration of my new locality.

I remained here nineteen days, and, considering the shortness of the time, made a very good collection of monkeys, birds, and insects. A considerable number of the species (especially of insects) were different from those of the four other stations, which I examined on the south side of the Solimoens and as many of these were "representative forms"* of others found on the opposite banks of the broad river, I concluded that there could have been no connection between the two shores during, at least, the recent geological period. This conclusion is confirmed by the case of the Uakari monkeys, described in the last chapter. All these strungly modified local races of insects confined to one side of the Solimoens (like the Uakaris), are such as have not been uble to cross a wide treeless space such as a river. The acquisition which pleased me most, in this place, was a new species of buttertly (a Catagramma), which has since been named C. excelsior, owing to its surpassing in size and beauty all the previously-known species of its singularly beautiful genus. The upper surface of the wings is of the richest blue. varying in shade with the play of light, and on each side is a broad curved stripe of an orange color. It is a bold flier, and is not

* Species or races which take the place of other allicd species or races. 
conflned, as I ufterward found, to the northern side of the river, for once I saw a specimen amid a number of richly-colored buttertlies, flying about the deck of the steumer when we were anchored off Fonte Boa, 200 miles lower down the river.

With the exception of three mameluco families and a stray Portuguese trader, all the inhabitants of the village and neighborhood are semi-civilized Iudians of the Shumáu and Passé tribes. Thu forests of the Tuuntins, however, are inhubited by a tribe of wild Indians culled Caishánas, who resem. ble much, in their social conditions aud manners, the debased Múras of the Lower Amazous, and have like them, shown no aptitude for civilized life in uny shape. Their huts commence at the distance of an hour's walk frum the village, along gloomy and narrow forest paths. My first and only visit to a Caisháua dwelling was accidental. One day, having extended my walk further than usual, and followed one of the forest-roads until it became a mere picada, or hunter's track, I cune suudenly upon a well-trodden pathway, bordered on each side with Lycopodia of the most elegant shapes, the tips of the fronds stretching almost like tendrils down the little eurthy slopes which formed the edge of the path. The road, though smouth, was narrow and dark, and in mauy places blocked up by trunks of felled trees, which had been apparently thrown across by the timid Indians on purpose to obstruct the way to their habitations. Half a mile of this shady road brought me to a small open space on the banks of a bruok or creek, on the skirts of which stuod a conical hut with a very low doorway. There was also an upen shed, with stages made of split palm stems, and a number of large wooden troughs. Two or three dark-skinned children, with a man and woman, were in the shed; but, immediately on espying me, all of them ran to the hut, bolting through the little doorway like so many wild animals scared into their burrows. A few moments after, the man put his head out with a luok of great distrust; but on my making the most friendly gestures I could think of, he cume forth with the children. They were all smeared with black mud and paint; the only clothing of the elders was a kind of apron made of the innner bark of the sapucaya tree, and the savage aspect of the man was heightened by his hair hanging over his forehead to the eyes. I stayed about two hours in the neighborhood, the children gaining sufficient confldence to come and help me to search for insects. The only weapon used by the Caishánas is the blow-gun, and this is employed only in shooting animals fur food. They are not a warlike people, like most of the neighboring tribes on the Japurá and Issá.

The whole tribe of Caishanas does not exceed in number 400 souls. None of them are baptized Indians, and they do not dwell in villages, like the more advanced sections of the Tupí stock: but each fumily has its own solitary hut. They are quite harmless, do not practice tattooing, or perforate their ears and noses in any way. Their social condition is of a low type, very little remured, indeed, from that of the brutes living in the same furests. They do not appear tu obey any common chief, and I could not make out that they had Pajés, or medicine men, those rudest beginnings of a priest class. Sym. bolical or masked dances, and ceremonies in honor of the Jurupari, or lemon, customs which prevail among all the surrounding tribes, are unknown to the Caishánas. There is among them a trace of festival keeping; but the only ceremony used is the drinking of cashirí beer, and fermented liquors mude of Indian corn, bananas, and so forth. These affairs, however, are conducted in a degenerate style, for they do not drink to intoxication, or sustain the orgies for several davs and nights in succession, like the Jurís, Pussés, and Tucúnas. The men play a musical instrument, made of pieces of stem of the arrow-grass cut in different lengths and arranged like Pan-pipes. With this they while away whole hours, lolling in ragged bast hammocks slung in their dark, smoky huts. The Tunantins people say that the Cajshánas.have persecuted the wild animals and birds to such an extent near their settlements that there is now quite a scarcity of animal food. If they kill a toucan, it is considered an important event, und the bird is made to serve us a meul for a score or more persons. They boil the meat, in earthenware kettles filled with Tucupí suuce, and eat it with beiju, or mandiocu cakes. The women are not allowed to taste of the meat, but are forced to content themselves with sopping pieces of cake in the liquor.

November 30th.-I left Tunantins in a trading schooner of eighty tons burden belonging to Senhor Batalla, a tradesman of Ega, which had been out all the summer collecting produce, and was commanded by a friend of mine, a young Paranese, numed Francisco Raiol. We arrived on the $3 d$ of December at the mouth of the Jutahi, a con. siderable stream abuut half a mile broad, and flowing with a very sluggish current. This is one of a series of six rivers, from 400 to 1000 miles in length, which flow from the south-west through unknown lands lying between Bolivia and the Upper Amazons, and enter this latter river between the Madeira and the Ucayáli. Wo remained at anchor four days within the mouth of the Sapb, a small tributary of the Jutahi flowing from the south-east, Seuhor Raiol having to send an igarité to the Cupatána, a large tributary some few miles farther up the river, to fetch a cargo of salt fish. During this time we made several excursions in the montaria to various places in the neighborhood. Our longest trip was to some Indian houses, a distance of fifteen or eighteen miles up the Sapó, a journey made with one Indian pad. dler, and occupying a whole ciay. The stream is not more than forty or fifty yards broud; its waters are darker in color than those of the Jutahi, and flow, as in ull these 
small rivers, partly under shade between two infty walls if forest. We passed, in ascending, seven habitations, most of them hidden in the luxuriant foliage of the banks: their sites being known only by emall openings in the compact wall of forest, and the presence of a canve or two tied up in little shady ports. The inhabitants are chiefly Indians of the Maraná tribe, whose originul territory comprised all the small by-streams lying be. tween the Jutahi and the Juruá, neur the mouths of both these great tributaries. They live in separate families or small hordes; huve no common chitf, and are considered us a tribe little disposed to adopt civilized customs or be friendly with the whites. One - f the houses belonged to a Juri family, and we saw the owner, an erect, noble-looking old fellow, tattooed, as customary with his tribe, in a large patch over the middle of his face, fishing under the shade of a colossal tree in his poit with hook and line. He saluted us in the usual grave and courteous manner of the better sort of Indians as we passed by.

We reached the last house, or rather two houses, about ten o'clock, and spent there several hours during the great leat of midday. The houses, which stood on a high clayey bunk, were of quadrangular shape, partly open like sheds, and partly enclosed with rude mud-walls, forming one or more chambers. The inhabitants, a few families of Marauás, comprising about thirty persons, received us in a frank, smiling manner, a reception which may have been due to Senhor Raiol being an old acquaintance and somewhat of a favorite. None of them were tattwoed, cut the men had great holes pierced in their ear-lobes, in which they insert plugs of wood, and their lips were drilled with smaller holes. One of the younger men, a fine strapping fellow nearly six feet high, with a large aquiline nose, whe seemed to wish to le particularly friendly with me, slowed me the use of these lip-holes, by fix. ing a number of little white sticks in them. and then twisting his mouth about and going through a pantomime to represent defiance in the presence of an enemy. Nearly ull the peop'e were disfigured by dark blotches on the skin, the effect of a cutaneous disease very prevalent in this part of the country. The face of one old inan was completely blackened, and looked as though it had been smeared with black-kad, the blotches having coulesced to from one large patch; others were simply mottled. The black spots were hard and rough, but not scaly, and were margined with rings of a color paler than the natural hue of the skin. I had seen many Indians and a few half-castes at Tunantins, and afterward saw others at Fonte Boa, blotched in the same way. The disease would seem to be contagious, for I was told that a Portuguese trader became disfigured with it after cohabiting some years with an Indian woman. It is curious that, although prevalent in many places on the Solimuens, 20 resident of Ega exhibited signs of the dis- ease. The early explorers of the country, on noticing spotted skins to be very frequent in certain localities, thuught they were peculiar to a few tribes of Indians. The younger children in these houses on the Sapó were free from spots ; but two or three of theni, about ten yeurs of age, showed signs of their commencement in rounded yellowish patches on the skin, and these appeared languid ant sickly, although the blot:hed adults seemed not to be affecter in their general health. $\Lambda$ middle-aged half-caste at Funte $B$.3a told ms he had cured himself of the disorder by strong doses of sarsaparilla; the black patches had caused the hair of his beard an: eyebrows to full off, but it had grown again since his cure.

We left these friendly people about four o'clock in the ufternoon, and in desceuding the umbrageous river, stopped, about halfway down, at another house, built in one of the most charming situations I had yet seen in this country. A clean, narrow, sandy pathivay led from the shady port to the house, through a tract of forest of indescribable luxuriance. The buildings stood on an eminence in the middle of a level, cleared space, the firm sandy soil. wmooth as a floor, forming a broad terrace around them. The owner was a semi-civilized Indian, named Manoel, a dull, taciturn fellow, who, to. gether with his wife and childreu, seemed by no means pleased at being intruded on in their solitude. The family must have been very industrious; for the plantations were very extensive, and included a little of almost all kinds of cultivated tropical productionsfruil trees, vegetables, and even flowers for ornament. The silent old man had surely a fine appreciation of the beauties of nature, for the site lie had chosen commanded a view of surprising magnificence over the summits of the forest ; and, to give finish to the prospect, he had planted a large quantity of hanana trees in the foreground, thus concealing the charred and dead stumps which would otherwise have marred the effect of the rolling sea of greenery. The only information I could get out of Manoel was that large flocks of richly-colored birds came down in the fruit seuson and despoiled his trees. The sun set over the tree-tops before we left this little Eden, and the remainder of our journey was made slowly and pleasantly. under the checkered shades of the river banks, by the light of the moon.

December 7th.-Arrived at Fonte Boa, a wretched, muddy, and dilapidated village, situated two or three miles within the mouth of a narrow by-stream called the Cayhlarhy, which runs almost as straight as an artificial canal between the village und the main Amazons. The character of the vegetation and soil here was different frum that of all other lucalities 1 had hitherto examined; I hal planned, therefore, to devote six weeks to the place. Having written beforehand to one of the principal inhabitants, Benhor Venancio, a house was resdr for me on lanú. 
ing. The only recommendation of the dwelling was its coolness. It was, in fact, de. cidedly damp ; the plustered walls bore a crop of green mould, and a slimy moisture oozed through the black, dirty floor; the rooms were large, but lighted by miseruble little holes in place of windows The village is built on a clayey plateau, and the ruinous houses are arranged round a large square, which is so choked up with tangled bushes that it is quite impassable, the luzy inhabitants having allowed the fine open space to relapse into jungle. The stiff, clayey eminence is worn into deep gullies which slope towurd the river, and the ascent from the port in rainy weather is so slippery that one is obliged to crawl up to the streets on allfours. A large tract of ground behind the place is clear of forest, but this, as well as the streets and gardens, is covered with a dense, tough carpet of shrubs, having the same wiry nature as our common heath. Beneath its deceitful covering the soil is always moist and soft, and in the wet season the whole is converted into a glutinous mud swamp. There is a very pretty church in one corner of the square, but in the rainy months of the yeur (nine out of twelve) the place of worship is almost inaccessible to the inhabitants on account of the mud, the only means of getting to it being by hugging closely the walls and palings, and so advanc. ing sideways step by step.

I remained in this delectable place until the 25th of Junuary, 1857. Fonte Boa, in addition to its other amenities, has the reputation throughout the country of being the headquarters of mosquitoes, and it fully deserves the title. They are more annoying in the houses by day than by night, for they swarm in the dark and damp rooms, keeping, in the daytime, near the floor, and settling by halfdozens together on the legs. At night the culico tent is a sufficient protection; but this is ubliged to be folded every morning, and in letting it down before sunset, great care is required to prevent even one or two of the tormentors from stealing in beneath, their insatiable thirst for blood and pungent sting making these enough to spoil all comfort. In the forest the plague is much worse; but the forest-mosquito belongs to a different species from that of the tow $n$, being much larger, and having transparent wings ; it is a litile cloud that one carries about one's per. son every step on a woodland rumble, and their hum is so loud that it prevents one learing well the notes of birds. The town mosquito has opaque speckled wings, a little less severe sting, and a silent way of going to work ; the inhabitan's ought to be thankful the big noisy fellows never come out of the forest. In compensation for the abundance of mosquitoes, Fonte Boa has no piums; there was, therefore, some comfort outside one's door in the day time ; the comfort, however, was lessened by there being scarcely uny room in front of the house to sit down or walk about in, for, on our side of the square, the causeway was only two feet broad, and to step over the boundary, formed by a line of slippery stems of palms, was to sink up to the knees in a sticky swamp.

Notwithstanding damp and mosquitoes, I had capital health and enjoyed myself much at Fonte Boa; swampy and weedy places being generally more healthy than dry ones on the Amazons, probably owing to the absence of great radiation of heat from the ground. The forest was extremely rich and picturesque, although the soil was everywhere clayey and cold, and broad pathways threaded it for many a mile over hill and dale. In every hollow flowed a sparkling brook, with perennial and crystal waters. The margins of these streams were parudises of leatiness and verdure; the most striking feature being the variety of ferns, with immense leaves, some terrestrial, others climb. ing over trees, and two, at least, arborescent. I saw here some of the largest trees I had yet seen. There wus one especially, a cedar, whose colossal trunk towered up for more than a hundred feet, straight as an arrow ; I never saw its crown, which was lost to view, from below, beyond the cruwd of lesser trees which surrounded it. Birds and monkeys in this glorious forest were very abundant; the bear like Pithecia hirsuta being the most remarkable of the monkeys, and the Umbrella Chatterer and Curl-crested Toucans among the most beautiful of the birds. The Indians and half-castes of the village had made their little plantations, and built huts for summer residence on the banks of the rivulets, and my rambles generally terminated ut one or other of these places. The people were always cheerful and friendly, and seemed to be glad when I proposed to join them at their meals, contributing the contents of my provision-bay to the dinner, and squatting down among them on the mat.

The village was formerly a place of more importance than it now is, a great number of Indians belonging to the most industrious tribes, Shumánas, Passés, and Cambévas, having settled on the site and adopted civilized habits, their industry being directed by a few whites, who seem to have been men of humane views as well as enterprising traders. One of these old employers, Senhor Guer: reiro, a well-educuted Paraense, was still trading on the Amazons when I left the country, in 1859 ; he told me that forty years previously Fonte Boa was a delightful place to live in. The neighborhood was then well cleared, and almost free from mosquitoes, and the Indians were orderly, industrious, and happy. What led to the ruin of the settlement was the arrival of severul Portuguese and Brazilian traders of a low class, who, in their eagerness for business, taught the easy-going Indians all kinds of trickery and immorality. They enticed the men and women away from their old employers, and thus broke up the large establishments, compelling the principals to take their capital to other places. At the time of my visit there were few pure-blood Indians at Fonte Bua, and no true whites The inhahitunts seemed 
to be nearly all mamelucos, and were a looselivıng, rustic, plain-spoken, and iynorant se: of people. There was no priest or school. master within 150 miles, and had not been any for many years, the people seemed to be -almost without government of any kind, and yet crime and deeds of vioience appeared to be of very rare occurrence. The principa! man of the village, one Senhor 'usto, was \&; lig, coarse, energetic fellow, sub-rlelegado of police, aud the only tradesman who ownec al lurge vessel running directly between Foute Boa and Pará. He had recently built a large house, in the style of middle-class dwellings of towns, numely, with brick floors and tilcd ronf, the bricks and tiles luving been brought from Pará, 1,500 miles distant, the nearest place where they are manufactured in surplus. When Senhor Justo visited me, he was much struck with the engravings in a file of Illustrated London Neros, which lay on my table. It was impossible to resist his urgent entreaties to let him have some of them " to look at," so one day he carried off $u$ portion of the papers on loan. A fortvight afterward, on going to request him to return them, I found the engravings had been cut out, and stuck all over the newly whitewashed walls of his chamber, many of them upside down. He thought a room thus decorated with foreign views would increase his importance among his neighbors, and when I yiclded to his wish to keep them, was boundless in demonstrations of gratitude, ending by shipping a boat load of tirtles for my use at Ega.

These neglected and mue villagers still re. tained many religious practices which former missionaries or priests had taught them. The ceremony which they observed at Christ. mas, like that described as practised by negroes in a former chapter, was very pleasing for its simplicity, and for the heartiness with which it was conducted. The church was opened, dried, and swept clean a few days before Christmus eve, and on the morn. ing all the women and children of the village were busy decorating it with festoons of leaves and wild flowers. Toward midniugt it Wus illuminuted inside and out with little oll lamps, made of clay, and the image of the "Menino Deus,' or Child-Gud, in its crudle, was placed below the altar, which was inghted up with rows of wux candles-very lean ones, but the best the piror people could afford. All the villagers assembled soon afterward, dressed in their best, the women with flowers in their hair, and a few simple hymns, totally irrelevant to the occasion, but probably the only ones known by them, were sung kneeling ; an old half-caste, with bluck spotted face, leading off the tunes. This finished, the congregation rose, and then marched in single file up one side of the church and down the other, singing together a very pretty marching chorus, und each one, on reaching the little image, stooping to kiss the end of a ribbon which was tied round its waist. Considering that the ceremnay was got up of their own free will, and at consid. erable expense, I thought it spoko well for the good intentions and simplicity of heart of these poor neglected villagers.

I left Fonte Boa, for Ega, on the 25th of January, making the passage by steamer, lown the middle of the current, in sixteen lours. The sight of the clean and neat little town, with its open spaces, close-cropped grass, broad lake, und white sandy shores, iad a most exhilarating effect, after my trip into the wilder puits of the country. The district between Ega and Loret, the first Peruvian village on the river, is, indeed, the most remcte, thinly-peopled, and barbarous of the whole line of the Amazons, from oceun to ocean. Beyond Loreto, signs of civilization, from the side of the Pacific, begin to be numerous; and from Eya, downward, the improvement $i$, felt from the side of the Atlantic

September 5th, 1857.--Again embarked ory the Tabatinga, this time for a longer ex. cursion than the last, namely, to St. Paulo de Olivença, a village higher up than any 1 had yet visited, being 260 miles distant in a straight line from Ega, or about 400 miles, following the bends of the river.

The waters are now nearly at their lowest puint; but this made no difference to the rate of travelling, night or day. Several of the Paraná-mirims, or bj-channels, which the steamer threads in the season of full-water, to save a long circuit, were now dried up, their empty beds looking like deep sandy ravines in the midst of the thick forest. Tho large sand islands, and miles of sandy beach, were also uncovered; and these, with the swarms of large aquatic birds, storks, herons, ducks, v'aders, and spoon-bills, which lined their margins su certain places, mado the river view much more varied and aniinated than it is in the season of the fluod. Alligators of large size were commun near the shores, lazily floating, and heedless of tho passing steamer. The passengers amused themselves by shouting at them from tho deck with a double-barrelled rifle we ha.l on board. The sign of a mortal hit was the monster turuing suddenly over, and remaining floating, with its white belly upwarl. Lieutenant Nunes wished to have one of the dead animals on buard, for the purpose of opening the abdomen, and, if a male, extracting a part which is held in grent estimation amung Braziliuns as a " remedio," charm or medicine. The steamer was stopped, and a b wat sent, with four strong men, tos embark the beast the body, however, was found too heavy to be lifted intu the boat; so a rope was passed round it, and the hideous creature towed alongside, and hoisterl on deck by means of the crane, which was rigged for the purpose. It had still some sparks of life, and when the knife was applied, lashed its taii, and opened its enormous jaws, sending the crowd of bystanders flying in all directions. A blow with a lutchet, on the crown of the head, gave him his quietus at lust. The Jrigti if the animal was fifteen feet; but was olaterneut can give but an imperfect idea 
of its Immense bulk and weight. The number of turtles which were seen swimming in quiet shoaly bays passed on the road, also gave us much amusement. They were seen by dozens ahead, with their snouts peering above the surface of the water, and, on the steamer approaching, turning round to stare, but not losing confidence till the vessel had nearly passed, when they appeared to be suddenly smitten with distrust, diving like ducks under the stream.

The river scenery about the mouth of the Japura is extremely grund, and was the subject of remark among the passengers. Lieutenant Nunes gave it as his opinion that there was no diminution of width or grand. eur in the mighty stream up to this point, a distunce of 1500 miles from the Atlantic; and yet we did not here see the shores of the river on both sides at once; lines of islands or tracts of alluvial land, having by-chaunels in the rear, intercepting the view of the northern mainland, and sometimes also of the southern. Beyond the Issa, however, the river becomes evidently narrower, being reduced to an average width of about a mile; there were then no longer those magnificent reaches, with blank horizons, which occur lower duwn. We had a dark and rainy night after passing Tunantins, and the passengers were all very uneusy on account of the speed at which we were travelling, twelve miles an hour, with every plank vibrating with the force of the engines. Many of them could not sleep, myself among the number. At length, a litthe after midnight, a sudden shout starled us: "Back her!" (English terms being used in matters relating to steam-engines.) The pilot instantly sprang to the helm, and in a few moments we felt our padddle box brushing against the wall of forest into which we had nearly driven headlong. Fortunately, the water was deep close up to the bank. Early in the morning of the 10th of September we anchored in the port of St. Paulo, after five days' quick travelling from Ega.

St. Puulo is built on a high hill, on the southern bank of the river. The hill is formed of the same T'abatinga clay which occurs at intervals over the whole valley of the Amazons, but nowhere rises to so great an elevation as here, the height being about 100 feet above the mean level of the river. The ascent from the port is steep and slippery ; steps and resting-places have been made, to lighten the fatigue of mounting, otherwise the village would be almost inac vessible, especially to porters of luggage and cargo, for there are no means of making a tircuitous road of more moderate slope, the bill being steep on all sides, and surrounded by dense forests and swamps. The place sontains about 500 inhabitants, chiefly half. zastes and Indians of the Tucunia and Colúna tribes, who are : very little improved from their primitive state. The streets are aarrow, and in rainy weather inches deep in mud; many houses are of substantial structure, but in a ruinous condition, and the Dluce altogether presents the appearance, like
Fonte Boa, of having seen better days Signs of commerce, such as meet the eve at Ega, could scarcely be expected in this remote spot, situate 1800 miles, or seven months ${ }^{3}$ round voyage by sailing-vessels, from Pará, the nearest market for produce. A very short experience showed that the inhabitants were utterly debased, the few Portuguese and other immigrants having, instead of promoting industry, adopted the lazy mode of life of the Indians, spiced with the practice of a few strong vices of their own introduction.

The head-man of the village, Senhor Antonia Ribeiro, half-white, half-Tucúna. prepared a house for me on landing, and introduced me to the principal people. The summit of the hill is grassy table-land, of twn or three hundred acres in extent. The soil is not wholly clay, but partly sand and gravel; the village itself, however, stands chiefly on clay, and the streets, therefure, after heavy rains, become filled with muddy puddles. On damp nights the chorus of frogs and toads which swarm in weedy back yards, creates such a bewildering uprour that it is impossible to carry on a cunversation in-doors except by shouting. My house was dumper even than the one I occupied at. Fonte Boa, and this made it extremely diffcult to keep my collections from beingspoiled by mould. But the general humidity of the atmosphere in this part of the river was evidently much greater than it is lower down ; it appears to increase gradually in ascending from the Atlantic to the Andes. It was impossible at St. Paulo to keep salt for many days in a solid state. which was not. the case at Ega, when the baskets in which it is contained were well wrapped in leaves. Six degrees further westward, namely, at the foot of the Andes, the dampness of the climateof the Amazonian forest region appears to. reach its acme, for Poeppig found at Chin. chao that the most refined sugar in a few days dissolved into syrup, and the best gun. powder became liquid, even when enclosed in canisters. At St. Paulo refined sugarkept pretty well in tin boxes, and I had no difficulty in keeping my gunpowder dry in canisters, although a gun loaded over-night: could very seldom be fired off in the morning.

I remained at St. Paulo five months ; five years would not have been sufficient to exhaust the treasures of its neighborhuod in zoology and botany. Although now a forest-rambler of ten years' experience, the beautiful forest which surrounds this settlement gave me as much enjuyment as if I had. only just landed for the first time in a tropical country. The plateau on which the village is built extends on one side neurly a mile into the forest, but on the other side the descent into the lowland begins cluse to the strects, the hill sloping ubruptly toward a boggy meadow surrounded by woods, through which a narrow winding path con. tinues the slope down to a coul, shady glen, with a brook of icy-cold water flowing at thebottom. At mid-day the vertical sun pene- 
Erates into the gloomy depths of this romanic spot, lightiug up the leafy banks of the rivulet and its cleau sandy margins, where numbers of scarlet, green, and black tanagers :and brightly-colored butterflies sport about in the stray beams. Sparkling brooks, large and smull, traverse the glorious forest in almost every direction, and one is constantly meeting, while rumbling through the thickets, with trickling rills and bubbling springs, so well provided is the country with moisture. Some of the rivulets flow over a sandy and pehbly bed, and the banks of all are clothed with the most magnificent vegetation conceivable. I had the almost daily habit, in my solitary walks, of resting on the clean banks of these swift-flowing streams, and bathing for an hour at a time in their bracing waters; hours which now remain among my most pleasant memories. The broad forest roads continue, as I was told, a distance of several days' journey into the interior, which is peopled by Tucúnus and other Indians, living in scattered houses and villages, nearly in their primitive state, the nearest village lying about six miles from St. Paulo. The banks of all the streams are dotted with palm-thatched dwellings of Tucúnas, all half-buried in the leafy wilderness, the scattered families having chosen the coolest and shadiest nooks for their abodes.

I frequently heard in the neighborhood of these huts the " realejo" or organ bird ( $\mathrm{Cy}$ phorhinus cantans), the most remarkable song. rster, by far, of the Amazonian forests. When its singular nutes strike the ear for the first time the impression cannot be resisted that they are produced by a human voice-some musical boy must be gathering fruit in the thickets, and is singing a few notes to cheer himself. The tones become more fluty and plaintive; they are now those of a flageolet, and notwithstanding the utter impossibility of the thing, one is for the moment convinced that somebody is pleying that instrument. No bird is to be seen, however closely the surrounding trees and buehes may be scanned, and yet the voice seems to come from the thicket close to one's ears. The ending of the song is rather disappointing. It begins with a few very slow and mellow notes, following each other like the commencement of an air; one listens expecting to hear a complete strain, but an abrupt pause occurs, and then the song breaks down, finishing with a number of clicking unmusical sounds like a piping barrel-organ out of wind and tune. I never heard the bird on the Lower Amazons, and very rarely heard it even at Ega ; it is the only songster which makes an impression on the natives, who sometimes rest their paddles while truvelling in their - small canoes along the shady by-streams, as $\therefore$ struck by the mysterious sounds.

The Tucuna Indians are a tribe resembltuce much the Shumánas, Passés, Jurís, and Mauhés in their physical appearance and customs. They lead, like those tribes, a settled agricultural life, each horde obeying a chief of more or less influence, accordicg to his energy and ambition, and possessing its pajé or medicine man, who fosters its superstitions; but they are much more idle and debauched than other Indians belongiug to the superior tribes. They are not so warlike and loyal as the Mundurucús, although re. sembling them in many respects, nor have they the olender figures, dignifled mien, and gentle disposition of the Passés; there are, however, no trenchant points of difference to distinguish them from these highest of all the tribes. Both men and women are tattooed, the pattern being sometimes a scroll on each cheek, but generally rows of short straight lines on the face. Most of the older people wear bracelets unklets, and garters of tapir hide or tough bark; in their homes they wear no other dress except on festival days, when they ornament themselves with feath. ers or masked cloaks made of the inner bark of a tree. They were very shy when I made my first visits to their habitations in the for. est, all scampering off to the thicket when I approached, but on subsequent days they became more familiar, and I found them a harmless, good-natured people.

A great part of the horde living at the first Maloca or village dwell in a common habitation, a large oblong hut built and arranged inside with such a disregard of all symmetry that it appeared as though constructed by a number of hands, each working independ. ently, stretching a rafter or fitting in a piece of thatch, without reference to what his fellow-laborers were doing. The walls as well as the roof are covered with thatch of palm leaves, each piece consisting of leaflets plaited and attached in a row to a lath many feet in length. Strong upright posts support the roof, hammocks being slung between them, leaving a free space for passage and for fires in the middle, and on one side is an elevated stage (girao) overhead, formed of split palmstems. The Tucúnas excel most of the other tribes in the manufacture of pottery. They make broad-mouthed jars for Tucupi sauce, caysúma or mandinca beer, capable of holding twenty or more gallons, oruamentiug them outside with crossed diagonal streaks of various colors. These jars, with cookingpots, smaller jars for holding water, blowguns, quivers, matiri bags full of small articles, baskets, skins of animuls, and so forth, form the principal part of the furniture of their huts, both large and small. The dead bodies of their chiefs are interred, the knees duubled up, in large jars under the floors of their huts.

The semi-religious dances and driuking bouts usual among the settled tribes of $\mathrm{Am}$ azonian Indiaus are indulged in to greater excess by the Tucúnas than they are by most other tribes. The Jurupari or Demon is the ouly superior being they have auy concep. tion of, and his name is mixed up with all their ceremonies, but it is difficult to ascertain what they consider to be his attributes. He seems to be believed in simply as a mischievous imp, who is at the bottom ef all 
those mishap: of their daily life, the causes of which are not very immediate or obvious to their dull understandings. It is vain to try to get iniormation out of a Tucúna on this subject ; they affect great mystery when the name is mentioned, and give very confused answers to questions. It was clear, however, that the idea of a spirit as a bene. ficent God or Creator had not entered the minds of these Indians. There is great similarity in all tineir ceremonies and nummeries, whether the object is a wedding, the celebration of the feast of fruits, the plucking of the hair from the heads of their children, or a holiduy got up sirnply out of a love of dissipation. Some of the tribe on these occasions deck themaselves with the bright-colored feathers of parrots and macaws. Thw chief wears a head-dress or cap mude by fir ing the breast-feathers of the Tuxcan on web of Bromelia twine, with ert.t tail. plumes of macaws rising from the crown. The cinctures of the arms and legs are : lso then ornamented with bunches of feathers. Others wear masked dresses. These are long sloaks reaching below the knee, and made of the thick whitish-colored inner bark of a tree, the fibres of which are interlaced in so regular a manner, that the material looks like artificial cluth. The gloak covers the head; two holes are cut out for the eyes, a large round piece of the sloth stretched on a rim of flexible wood is stitched on each side to represent ears, and the fentures are painted in exagzerated style with yellow, red, and jlack 3treaks. The dresses are sewn into the proper shapes with thread made of the inner bark of the Uaissim: tree. Sumetimes grotesque head-dresses, representing munkeys busts or heads of other animals, mado by stretchin $g$ cloth or skin over a basket-work frume, are worn at these holidays. The biggest and ugliest mask represents the Juruparí. In these festival habiliments the Tucinas go through their monotonous see-saw and stamping dances, accompanied by singing and drusuming, and keep up the sport often for three or four days and nights in succession, dinking enormous quantities of caysúma, smoking toluccio, and snuffing paricá powder.

I could not learn that there was any deep symbolical meaning in these masked dunces, or that they commemorated any past event in the histury of the tribe. Some of them seem vaguely intended as a propitiation of the Jurupari, but the masker who represents the demon sometimes gets drunk along with the rest, and is not treated with any reverence. From all I could make out, these Indians preserve no memory of events going beyond the times of their fathers or grandfathers. Almost every joyful event is made the occasion of a festival-weddings amoug the rest. A young man who wishes to wed a Tucúna girl has to demanil her hand of her parents, who arrange the rest of the affair and fix a day for the marriage ceremony. A wedding which took place in the Christmas week while I was at St. Paulo, was kept uj with great spirit for three or four đays, tas ging during the heats of mid-day, bat renewjug itself with increased vigor every evening. During the whole time the bride, decked out with feather ornaments, was under the charge of the older squaws, whose business seerned to be sedulously to keep the bridegroom at a safe distance until the end. of the dreary period of dancing and boosing. The Tucúnas have the singular custom, in common with the Collivas and Mauhes, of treating their young girls, on their showing: the first signs of womanhoed, as if they had committed some crime. They are sent up to the girso under the smoky and filthy roof, and kept there on very meagre diet, sometimes for a whole month. I heard of one: poor girl dying under this treatment.

The only uther tribe of this neighborhood concerning which I obtained any information where the Majerónas, whose territory embraces several hundred miles of the western bank of the River Jauarí, an affluent of the Solimoens, 120 miles beycnd St. Puulo. These are a fierce, indomitable, and hostile people, like the Aıáras of the River Madeira : they are also cannibals. The navigation of the Jauari is rendered impossible on account of the Majeronas lying in wait on its banks to intercept and murder all travellers, especially whites.

Four months before my arrival at St. Pawlo, two young half-castes (nearly white) of the village went to trade on the Jauari, the Majesonas having shown signs of qbating their hustility for a year or iwo previously. They had nut been long gone, when their cance returned with the news that the two young felluws had been shot with arrows, roasted, and eaten by the savages. José $\mathrm{Pa}$ tricio, with his usual activity in the cause of law and order, despatched a party of anmed men of the National Guard to the place to make inquiries, and, if the murder should appear to be unprovoked, to retaliate. When they reached the settle ment of the horde who had eaic n the two men, it was found evacuated, with the excepticu of one girl, who had been in the roods when the rest of her penple had taken flight, and whom the guards brought with $11 \mathrm{t} m$ to St. Paulo. It was gathered from her, and from other Indians on the Jauari, that the young men had brought their fate on themselves through improper conduct towad the Majeróna women. The girl, on urriving ut St. Paulo, was taken care of by Sinhor José Patricio, baptized under the name of Maria, and taught Portuguese. I saw a good deal of her, for my friend sent her daily to my house to fill the water jars, make the fire, and so forth. I also gained her guod will by extracting the grub of an CEsirus fly from her back, und thus cured her of a painful tumor. Slie was decidedly the best-humored and, to all appearunce, the kindest-hearted specimen of her race I had yet seen. Slie was tall and very stout ; in color much lighter than the ordinary. Indian tint, and her ways altogether were more like those of a careless. 


\section{THE NATURALIST ON THE RIVER AMAZONS.}

Jaughing country wench, such as might be met with any day among the laboring class in villages in our own country, than a cannibal. I heard this artless muiden relate, in the coolest manner possible, how she ate $u$ portion of the bodies of the young men whom her iribe had roasted. But what increased greatly the incongruity of this business, the young widow of one of the victims, a neighbor of mine, happened to be presert. during the narrative, and showed her interest in it by laughing at the broken Portuguese in which the girl related the horrible stors

In the fourth month of my sojourn as o't. Paulo I had a serious illness, an attack of the "sizoens," or ague of the country, which, as it left me with shattered health and damped enthusiasm, led to my abandoning the plan I had formed of proceeding to the Peruvian tuwns of Pebas and Moyobamba, 250 and 600 miles further west, and so completing the examination of the natural history of the Amazouian plains up to the foot of the Andes. I made a very large collection at St. Paulo, and employed a collecior at Tabatinga and on the banks of the Jauari for several months, so that I acquired a very fair knowledge altogether of the productions of the country bordering the Amazons to the end of the Brazilian territory, a distance of 1900 miles from the Atlantic at the mouth of the Para ; but beyond the Peruvian boundary I found now I should be unable to go. My ague seemed to be the culmination of a gradual deterioration of health, which had been going on for several years. I had exposed myself too much in the sun, working to the utmust of my strength six daj's a week, and had suffered much, besides, from bad and insufficient food. The ugue did not exist at St. Paulo; but the foul and humid state of the village was, perhaps, sufficient to produce ague in a person much weakened from other causes. The country bordering the shores of the Solimoens is healthy throughout ; some endemic diseases certainly exist, but these are not of a fatal nature, and the epidemics which desolated the Lower Amazons from Pará to the Rio Negro, between the years 1850 and 1856, had never reached this favored land. Ague is endemic only on the banks of those tributary streams which have dark-minred water.

I always carried a stock of medicinos $\pi$ Ith me; and a small vial of quinine, which I had bought at Pará in 1851, but never yet had use for, now came in very useful. I took for each dose as much as would lie on the tip of a penknife-blade, mixing it with warm chamumile tea. The first few days after my first attack I could not stir, and was delirious during the paruxysms of fever ; but the worst being over, I made an effurt to rouse myself, knowing that incurable disurders of the liver and spleen fullow ague in this country if the feeling of lassitude is too much indulged. So every morning I shouldered my gun or insect-net, and went my usmal walk in the forest. The fit of shivermas very often seized ine before I got home, and I then. used to stand still and brave it out. When the steamer uscended in January 1858, Lieutenant Nunes was shocked to see me so much shattered, and recommended me strungly to return at once to Eya. I took bis advice. and embarked with hin, when he touched at St. Paulo on his downward voyage, on the $2 d$ of February. I still hoped to b, able to turu my face westward again, $t$, gather the yet unseen treasures of the mar. vellous countries lying between Tabatings and the slopes of the Andes; but although. after a short rest in Ega, the ague left we, my general health remained in a state too weak to justify the uudertaking of further journeys. At length I left Ega, on the $3 d$ of February, 1859, en route for England.

I arrived at Pará on the 17th of March, after an absence in the interior of seven years and a half. My old friends, Euglish, American, and Braziliun, scarcely knew me again, but all gave me a very warm welcome, es. pecially Mr. George Brocklehurst (of the firm of R. Singlehurst \& Co., the chief foreign merchants, who had been iny correspondents), who received me into his house, and treated me with the utmost kindness. I was rather surprised at the warm appreciation shown by many of the principal people of my lators; but, in fact, the interior of the country is still the "sertao" (wilderness)-a terra incoguita to most residents of the seaport-ind a man who had spent seven years and a half in exploring it, solely with scientific aims, was somewhat of a curiosity. I found Pará greatly changed and improved. It was no longer the weedy, ruinous, villagelooking place that it appeared when I first knew it in 1848. The population had been increased (to 20,000) by an influx of Portuguese, Madeiran, and German immigrants, and for many years past the provincial gov. erunient had spent their considerable surplus revenue in beautifying the city. The streets, formerly unpaved or strewn with loose stones and sand, were now laid with concrete in a most complete manner; all the projecting masonry of the irregularly-built houses had been cleared away, and the build. ings made more uniform. Most of the dilapidated houses were replaced by handsomo new edifices, having long and tegant balconiss:-runting the first floors, at an elevation of several feet above the roadway. The large swampy squares had been drained, weeded, and planted with rows of almond and casuarina trees, so that they were now a great ornament to the city, instead of an eyesore, as they formerly were. My old fuvorite road. the Monguba Arenue, had been renovated and joinea to many other magnificent rides lined with trees, which in a very few years had grown to a height sufficient to afford ayreeable shade; une of these, the Estrada de Sao José, had been planted with cocoa-nut palms. Sixty public vehicles, light cabriolets (some of them built in Pará), now plied in fhe streets, increasing much the animation of 
the beautiful squares, streets, and urenues

I found also the habits of the people considerably changed. Many of the old religious holidars had declined in inportance, and given way to secular amusements-social parties, balls, music, billiards, and su forth. There was quite us unch pleasure-seeking as furmurly, but it was turned in a more rational direction, and the Paruenses seemed now to siopy rather the customs of the northern nadiuns of Europe, than those of the mothercuntry, Purtugal. I whs glad to see sevesial new book-sellers' shops, and also a fine edifice devoted to a reading-room, supplied with perindicals, globes, and maps, and a circulating library. There were now many printing offices, and four daily newspapers. The health of the place had greatly improved since 1850 , the year of the yellow fever, and Pará was now considered no louger dangerous t.) new comers.

S.) much for the improvements visiole in the place, and now for the dark side of the picture. The expenses of living had increased about fourfold, a uatural consequence of the demand for labor and for native products of all kinds having augmented in greater ratio than the supply, through large arrivals of non - productive residents, and considerable importations of money on acr. unt of the steamboat company and foreign inerchants. Pará, in 1848, was one of the cheapest places of residence on the American continent; it was now one of the dearest. Imported articles of food, clothing, and furniture were mostly cheaper, although charged with duties varying from 18 to 80 per cent, besides high freights an 1 large profits, than thuse produced in the neighborhood. Salt cudfish was $t$ wopence per pound cheaper thun the vile salt pirarucú of the country. Oranges, which could formetly be had almost gratis, were now sold in the streets at the rate of three for a penny ; large bananas were a penny euch ; tomatoes were from twopence to ihreepence each, and all other fruit in this fruit-producing country had advanced in like proportion. Mandioca-meal, the bread of the country, had become so scarce and dear and bad, that the poorer classes of natives suffered fumine, und all who could affurd it were obliged to eat wheaten bread at fourpence to fivepence per pound, inade from American flour, 1200 barrth of which were consumed monthly ; this was now, therefore, a very serious item of vaily expense to all but the most wealthy. House-rent was most exorbitant; a miserahle little place of two roums, without fix. :ures or conveniences of any kind, having simply blank walls, cost at the rale of $£ 18$ sterling a year. Lastly, the hire of servants was beyond the means of all persous in moderate circumstunces; a lazy couk or porter could not be had for less than three or four shillings a day, besides his hoard and what he could steal. It cost me half-a-crown for the hire of a small boat and one man, to disembark from the steamer, a distance of 100 yards.
In rambling over my old ground in the forests of the neighborhood, I found great changes had taken place-to me, changes for the worse. The mantle of shrubs, bushes, and creeping plants which formerly, when the suburbs were undisturbed by axe of spade, had been left free to arrange itself in rich, full, and smooth sheets and masses over the forest borders, had been nearly all cut away, and troops of laborers were still $\mathrm{em}$. ployed cutting ugly muddy roads for carts and cattle, through the unce clean and lone'y woods. Houses and mills had been erected on the borders of these new roads The noble forest trees had been cut down, and their naked half-burned stems remained in the midst of ashes, nuddy puddles, and heaps of broken branches. I was obliged to hire a negro boy to show me the way to my favorite path near Una, which I have described in the secoud chapter of this narrative, the new clearings having quite oblitcrated the old forest ruads. Only a few acres of the glorious forest near Una now remained in their natural state. On the other side of the city, near the old road to the rice mills, several scores of woodmen were employed, under government, in cutting a broad carriage - road through the forest to Maranlam, the capital of the neighboring province, distant 250 miles from Pará, and this had entirely destroyed the solitude of the grand o:d forest path. In the course of a few years, however, a new growth of c1 eepers will cover the nuked tree-tiunks on the bor. ders of this new road, and luxuriant shrubs form a green fringe to the path; it will then become as beautiful a woodland road as the old one was. A naturalist will have, henceforwarl, to go farther from the city to lind the glorious forest scenery which lay so near in 1848 , and work much more laboriously than was formerly needed, to make the large collections which Mr. Wallace and I succeeded in doing in the neighborhood of Pará. June $2 d, 1859$.-At length, on the second of June, I left Pará. probabiy forever ; embatking in a Nurth American truding-vessel, the Frederick Demming, for New York, the United Slates route being the quickest as well as the pleasantest way of reaching England. My extensive private collections were divided into three portions, and sent by three separate ships, to lessen the risk of loss of the whole. On the evening of the $3 \mathrm{~d}$ of June, I took a last view of the glorious forest for which I had so much love, and to explore which I had devoted so many years. The saddest hours I ever recollect to have spent were those of the succeeding night, when, the mameluco pilut having leit us free of the shoals and out of sight of land, though within the mouth of the rirer, at anchor, waiting for the wind, I felt that the last link which connected me with the land of so many pieasing recollections was broken. The Paraenses, who are fully aware of the attractiveness of their countiy, have an alliterative proverb, "Quem vai para (o) Parś para." "He who ures io Paía stcos there." 
and I had often thought I should myself have been added to the list of examples. The desire, however, of seeing again my parents and enjoying once more the rich pleasures of intel.ectuai society had succeeded in overcoming the attractions of a region which may be fit tingly called a Naturalist's Paradise. During this last night on the Pará River a crowd of unusual thoughts occupied my mind. Recollections of English climate, scenery, and modes of life came to me with a vividness I had never before experienced during the eleven years of my absence. Pictures of startling clearness rose up of the gloomy winters, the long gray twilights murky atmosphere, elongated shadows, chilly springs, and sloppy summers; of factory chimneys and crowds of grimy operatives, rung to work in early morning by factory bells ; of union workhouses, confined rooms, artificial cares, and slavish conventionalities. To live again amid these dull scenes I was quitting a country of perpetual summer, where my life had been spent, like that of three fourths of the people, in gypsy fashion, on the endless streams or in the boundless forests. I was leaving the equator, where the well-bulanced forces of nature maintained a land-surface and climate that seemed to be typical of mundune order and beauty, to sail toward the North Pole, where lay my home under crepuscular skies somewhere about fifty-two degrees of latitude. It was natural to feel a little dismayed at the prospect of so great a chunge ; but now, after three years of renewed expe- rence or England, I find now incomparably superior is civilized life, where feelings, tastes, and intellect find abundunt nourishment, to the spiritual sterility of half-savage existence, even though it be passed in the Garden of Eden. What has struck me pow. erfully is the immeasurably greater dirersity and interest of human character and sociai conditions in a single civilized nution, than in equatorial South America, where three. distinct races of men live together. The superiority of the bleak north to tropical regions, however, is only in their sociul aspect ; for I hold to the opinion that, although humanity can reach an advanced state of culture only by battling with the inclemencies of nature in high latitudes, it is under the equator alone that the perfect race of the: future will attain to complete fruition of man's beautiful heritage, the earth.

The following day, having no wind, we drifted out of the mouth of the Pura with the: current of fresh water that is poured from the mouth of the river, and in twenty-four hours advanced in this way seventy miles on our road. On the 6 th of June, when in $7^{\circ}$ $55^{\prime} \mathrm{N}$. lat. and $52^{\circ} 30^{\prime} \mathrm{W}$. lung., and therefore about 400 miles from the mouth of the main Amazons, we passed numerous patches: of fioating grass mingled with tree-trunks and. withered foliage. Among these musses I espied many fruits of that peculiarly Amazonian tree the Cbussú palm; this was the: last I suW of the Great River.

THE END.

\section{CONTENTS.}

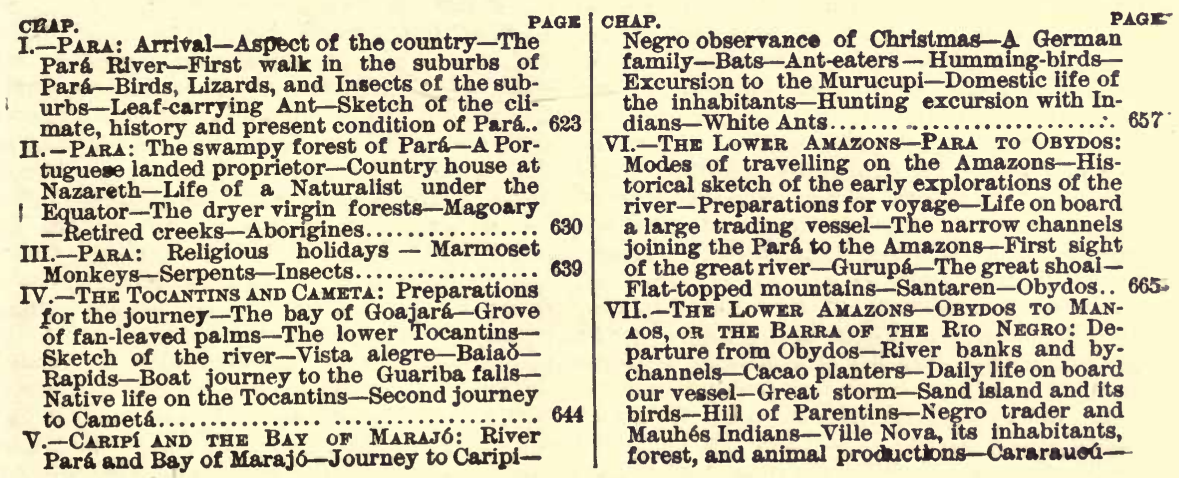


CEAP.

A rustic festival-Lake of Cararauch-Motaca flies-Serpa-Christmas holidays-River Madeira-A mameluco farmer-Mura IndiansRlo Negro-Description of Barra-Descent to Pará-Yellow fever..................... 6

VIII.-SANтAккм: Situation of Santarem-Manners and customs of the inhabitants-Climate -Grassy campos and woods-Excursions to Mapiŕ Mahicá, and Irurá, with sketches of their Natural History; Palms, Wildfruittrees, Mining Wasps, Mason Wasps, Bees, and Sloths............................ 689

IX.-VoYAGE UP THE Tipajos: Preparations for voyage-First day's sail-Loss of boat-Altar do Chao-Modes of obtaining fish-Difficulties with crew-Arrival at Aveyros-Excursions in the neighborhood - White Cebus, and habits and dispositions of Cebi Monkeys-Tame Parrot-Missionary settlement-Enter the river Cupari-Adventure with Anaconda-Smokedried Monkey - Boa-constrictor-Village of Munduruca Indians, and incursion of a wild tribe-Falls of the Cupari-Hyacinthine Macaw-Re-emerge into the broad Tapajos-

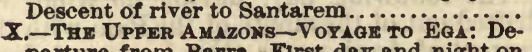
parture from Barra-First day and night on the Upper Amazons-Desolate appearance of
AGF | CHAP.

river In the flood season-Cucáma IndiansMental'condition of Indians-Squalls-Manatee -Forest-Floating pumice-stones from the Andes-Falling banks-Ega and its inhabitants -Daily life of a Naturalist at Ega-The four seusons of the Upper Amazons.............. XI.-EXCURSIONS IN THE NEIGHBORHOOD OF EGA: The River Teffé-Rambles through groves on the beach-Excursion to the house of a Passe chieftain-Character and customs of the Passe tribe-First excursion to the sand islands of the Solimoens-Habits of great river turtleSecond excursion-Turtle fishing in the inland pools-Third excursion - Hunting rambles with natives in the forest-Return to Ega.... 730

XII.-ANIMALS OF THE NeIGHBORHOOD OF EGA: Sarlet-faced Monkeys-Parauaca MonkeyOwl-faced Night-apes-Marmosets-JupuráBats-Birds-Cuvier's Toucan-Curl-crested Toucan-Insects-Pendulous Cocoons-Forag-

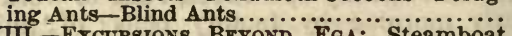
XIII.-EXcursions BEYOND EGA: Steamboat travelling on the Amazons-Passengers-Tunantins-Caishána Indians-The Jutahi-The Sapo-Maraúa Indians-Fonte Boa-Journey to St. Paulo-Tucuna Indians-IIIness-Descent to Pará-Changes at Para-Departure for England............................. 


\section{The Humboldt Library of Science}

Is the only publication of its kind, the only one containing popular scientific works al low prices. For the most part it contains only works of acknowledged excellence, by authors of the first rank in the world of science. In this series are well represented the writings of

$\begin{array}{lllll}\text { OARWIN, } & \text { HUXLEY, } & \text { SPENCER, } & \text { TYNDALL, } & \text { PROCTOR, } \\ \text { CLIFFORD, } & \text { CLODD, } & \text { BAGEHOT, } & \text { BAIN, } & \text { BATES, } \\ \text { WALLACE, } & \text { TRENCH, } & \text { ROMANES, } & \text { GRANT ALLEN, } & \text { GEIKIE, } \\ \text { HINTON, } & \text { SULLY, } & \text { FLAMMARION, } & \text { PICTON, } & \text { WILLIAMS, } \\ & \text { BALFOUR STEWART, } & \text { WILSON, } & \end{array}$

And other leaders of thought in our time. The books are Complete and Unabridged Editions, in Neat Paper Covers.

Price, FIFTEEN Cents a Number. Double Numbers, THIRTY Cents.

No. 1. Wight Science for Leisure Hours. A series of familiar essays on astronomical and other natural phenomena. By Richard A. Eroctor, F.R.A.S.

No. 2. Forms or Water in Clouds and Rivers, Ice and Glaciers. (I9 illustrations). By John Tyndall, F.R.S.

No. 3. Physies and Pollties. An application of the principles of Natural science to Political Society. By Walter Bagehot. author of "The English Constitution."

No. 4. Man's Place in Nature, (with numerous illustrations). By Thomas H. Huxley, F.R.S.

No. 5. Education, Intellectual, Moral, and Physical. By Herbert Spencer.

No. 6. Town Geology. With Appendix on Coral and Coral Reefs. By Rev. Chas. Kingsley.

No. 7. The Conservation of Energy, (with numerous illustrations). By Balfour Stewart, L, L.D.

No. 8. The Study or Languages, brought back to its true principles. By C. Marcel.

No. 9. The Data of Ethics. By Herbert Spencer.

No. xo. The Theory of sound in ite Felation to Musie, (numerous illustrations). By Prof. Pietro Blaserna.

No. 1x. (The Naturalist on the River Amazon. A record of 11 years of

Wo. 12. $\left\{\begin{array}{l}\text { F.I.S. (Double number. Not sold } \\ \text { separately). }\end{array}\right.$

Wo. 12. $\left\{\begin{array}{l}\text { F.I.S. (Double number. Not sold } \\ \text { separately). }\end{array}\right.$

No. 13. Mind and Body. The theories of their relation. By Alex. Bain, LI.D.

No. 14. The Wonderm of the Heavenn, (thirty-two illustrations). By Camille Flammarion.

No. 15. Longevity. The means of prolonging life after middle age. By John Gardner, M.D.
No. 16. On the Origin of Species. By Thomas H. Huxley, F.R.S.

No. 17. Progress: Its Law and Canse. With other disquisitions. By Herbert Spencer.

No. 18. Lessons in Electricity, (sixty illus(rations). By John Tyndall, F.R.S.

No. 19. Pamillar Esways on Selentific: Subjects. By Richard A. Proctor.

No. 20. The Romance of Astronomy. By R. Kalley Miller, M.A.

No. 21. The Physical Basis of Ife, with other essays. By Thomas H. Huxley, F.R.S.

No. 22. Seeing and Thinking. By William Kingdon Clifford, F.R.S.

No. 23. Seientific Sophisms. A review of current theories concerning Atoms, Apes and Men. By Samuel Wainwright, D.D.

No. 24. Popular Selentific Lectures. (illustrated). By Prof. H. Helmholtz.

No. 25. The Origin of Nations. By Prot. Geo. Rawlinson, Oxford University.

No. 26. The Evolutionist at Large. By Grant Allen.

No. 27. The Hintory or Landholding. in England. By Joseph Fisher, F.R.H.S.

No. 28. Fashion in Deformity, as illustrated in the customs of Barbarous and Civilized Races, (numerou illustrations). By William Henry Flower, F.R.S.

No. 29. Facts and Fietions of Zoology, (numerous illustrations). By Andrew Wilson, Ph. D.

No. 30. The Study of Words. Part I. By Richard Chenevix Trench.

No. 31. The Study of Words. Part II.

No. 32. Hereditary Traits and other Lissay \$. By Richard A. Proctor. 
No. 33. Viguettes from Nature. By Grant Allen.

No. 34. The Philosophy of Style. By Herbert Spencer.

No. 35. Oriental Religions. By John Caird, Pres. Univ. Glasgow, and Others.

No. 36. Lectures on Frolution. (Illustrated). By Prof. T, H. Huxley.

No. 37. Six Lectures on Light. (Ilustrated). By Prof. Tyndall.

No. 38. Geological Sketches. Part I. By Archibald Geikie, F.R.S.

-No. 39. Geological Sketches. Part II.

No. 40. The Evidence of Organic Evolution. By George J. Romanes, F.R.S.

No. 41. Current Discussion in Selence. By W. M. Williams, F.C.S.

No. 42, History of the Science of Polilics. By Frederick Pollock.

No. 43. Darwin and Ilumboldt. By Prof. Huxley, Prof. Agassiz, and others.

INo. 44. The Dawn or Hintory. Part I. By G. F. Keary, of the British Museum.

No. 45. The Dawn of History. Part II.

No. 46. The Diseases of Memory. By Th. Ribot. Translated from the French by J. Fitzgerald, M.A.

No. 47. The Childhood of Religion. By Edward Clodd, F.R.A.S.

No. 48. Hife in Nature. (Ilustrated). By James Hinton.

-No. 49. The Sun: its Constitution, its Phenomena, its Condition. By Judge Nathan T. Carr.

No. 50. Money and the Mechanism or Exchange. By Prof. W. Stanley Jevons, F.R.S. Part I.

No. 51. Money and the Mechanism or Exehange. Part II.

No. 52. The Diseases of the Will. By Th. Ribot. Translated from the French by J. Fitzgerald, M.A.

No. 53. Animal Automatism, and other Essays. By Prof. T. H. Huxley, F.R.S.

No. 54. The Birth and Growth of Myth. By Edward Clodd, F.R.A.S.

No. 55. The scientific Basis of Morals, and other Essays. By William Kingdon Clifford, F.R.S.

No. 56. Illusions. By James Sully. Part. I.

No. 57. Illusloms. Part II.

No. 58. The origin or Species. By Charles Darwin. Part I. (Double number).

No. 59. The Origin or Species. Part II. (Double Number).

No. 60. The Childhood of the World. By Edward Clodd, F.R.A.S.

2No. 6r. Mriscellaneous Essays. By Richard A. Proctor.
No. 62. The Religions of the Ancient World. By Prof. Geo. Rawlinson, Univ, of Oxford. (Double number).

No. 63. Progrengive Morality. By Thomas Fowler, LL.D, President of Corpus Christi Coll., Oxford.

No. 64. The Distribution of Animal and Plants. By A. Russell Wallace and W. T. Thistleton Dyer.

No. 65. Conditions of Mental Devel op:ment, and other Essays. By William Kingdon clifford.

No.66. Technical Education. and other Essays By Thomas H. Huxley, F.R.S.

No. 67. The IBlack Death. An account of the Great Pestilence of the Isth Century. By J. F. C. Hecker, M.D.

No. 68. Three Essays. By Herbert Spencer.

No. 69. Fetichism: A Contribution to Anthropology and the History of Religion. By Fritz Schultze, Ph. D. (Double number).

No. 70. Essays Speculative and Practical. By Herbert Spencer.

No. 71. Anthropology. By Daniel Wilson, Ph. D With Appendix on Archæology. By E. B. Tylor, F.R.S.

No. 72. The Daneing I Iania of the Mid. dle A ges. By J. F. C. Hecker, M.D.

No. 73. Evolution in History, Hanguage and seience. Four addresses delivered at the London Crystal Palace School of Art, Science and Literature.

No, 74. The Descent of Man, and SelecNo. 74. tion in Relation to Sex. (Numerous No. 75. $\begin{cases}\text { Illustrations). By Charles Darwin. } \\ \text {. B }\end{cases}$ No. 76. 7 Nos. $74,75,76$ are single Nos.; No. 77 is No. 77. ( a double No.

No. 78. Historical sketch of the Distribution of Land in wing. land. By William Lloyd Birbeck, M.A.

No. 79. Seientife A spect of some Familiar Things. By W. M. Williams.

No. 80. Charles Darwin. His Life and Work. By Grant Allen. (Double Number).

No. 81. The Mystery of Matter, and the Philosophy of Ignorance. Two Essays by J. Allanson Picton.

No. 82. IIIusions of the Senses, and other Essays. By Richard A. Proctor.

No. 83. Profit-Sharing Between Capital and Labor. Six Essays. By Sedley Taylor, $M$ A.

No. 84. Studies of Animated Nature. Four Essays on Natural History. By W. S. Dallas, F.I.S., and Others.

No. 85. The Essential Nature of ReligIon. By J. Allanson Picton.

No. 86. The Unseen Universe, and the Philosophy of the Pure Sciences. By Prof. Wm. Kingdon Clifford, F.R.S.

No. 87. The Morpline Habit. By Dr. B. Ball, of the Paris Faculty of Medicine. 
No 88. Science and Crime and other Essays. By Andrew Wilson, F.R.S.E.

No. 89. The Genesis of Sclence. By Herbert Spencer.

No. 9o. Notes on Earthquakes: with Fourteen Miscellaneous Essays. By Richard A. Proctor.

No. 91. The IRfse or Univernitles. By S. S. Laurie, LI.D. (Double number).

No. 92. The Formation of Vegetable Mould through the Action of Earth Worms. By Charles Darwin, LI.D., F.R.S. (Double number).

No. 93. Scientific Methods of Capital Punishment. By J. Mount Bleyer, M D.

No. 94. The Factors of Organic Evolutiom. By Herbert Spencer.

No 95. The Diseases of Personality. By Th. Ribot. Translated from the French by J. Fitzgerald, M A.

No. 96. A Half-Century of sefence. By Thomas H. Huxley, and Grant Allen.

No. 97. The Pleasures of Life. By Sir John Lubbock.

No. 98. Cosmic Emotion: Also the Teachings of Sclence. By William Kingdon Clifford.

No. 99. Nature Studies. By Prof. F. R Eaton Lowe; Dr. Robert Brown, F L.S ; Geo. G. Chisholm, F.R.G.S. and James Dallas, F.I.S.

No. 100. Science and Poetry, with other Essays. By Andrew Wilson, F.R S.E.

No. IoI. IEsthetics; Dreams and Association of Ideas. By James Sully and Geo. Croom Robertson.

No. 102. Ultimate Finance; A True Theory of Co-operation. By William Nelson Black.

No. 103. The Coming Slavery : The Sins of Legislators; The Great Political Superstition. By Herbert Spencer.

No. 104. Tropical Africa. By Henry Drummond, F.R.S.

No. 105. Freedom in Science and Teachiug. By Ernst Haeckel, of the University of Jena. With a prefatory Note by Prof. Huxley.

No. 106. Force and Energy. A Theory of Dynamfes. By Grant Allen.

No. 107. Ultimate Finanre. A True Theory of Wealth. By William Nelson Black.

No. 108. English, Past and Present By Richard Chenevix Trench. Part I. (Double number).

No. 109. English, Past and Present. Part II.

No. I10. The Story of Creation. A Plain Account of Evolution. By Edward Clodd. (Double number).

No. 111. The Pleasu res of Life. Part II. By Sir John Lubbock.
No. I12. Psychology or Attention. By Th. Ribot. Translated from the French by J. Fitzgerald, M.A.

No. 113. Hypnotism. Its History and Deve1opment. By Fredrik Björnström. M.D. Head Physician of the Stockholm Hospital, Professor of Psychiatry. Late Royal Swedish Medical Councillor. Authorized Translation from the Second Swedish Edition by Baron Nils Posse, M.G. Director of the Boston School of Gymnastics.. (Double number).

No. 114. Christianity and Agnostieism. A Controverwy. Consisting of papers contributed to The Nineteenth Century by Henry Wace, D.D. Prof. Thos. H. Huxley, The Bishop of Petersborough, W. H. Mallock, Mrs. Humphrey Ward. (Double number).

No. 115. Darwinism : An Exposition of the Theory of Natural Selection, with some of its Applications. By Alfred Russe1 Wallace, I.L.D., F.L.S, etc. Illustrated. Part I. (Double number).

No. 116. Darwinikm. Illustrated. Part II. (Double number).

No.II\%. Modern Science and Moderm Thought. By S. I,aing. Illustrated. (Double number).

No. I18. Modern Seicnce and Modern: Thought. Part II.

No. IIg. The Electrie Light and The Storing of Electrical Energy. Illustrated. Gerald Molloy, D.D., D.Sc.

No. 120. The IMndern Theory of Heat and The Sun as a storehouse of Energy. Illustrated. Gerald Molloy, D.D., D.Sc.

No. 121. Utilitarianism. By John Stuart Mill.

No. 122. Upen the Origin of Alpine and Italian Lakes and upon Glacial Erosion. Maps and Illustrations. By Ramsey, Ball, Murchison, Studer. Favre, Whymper and Spencer. Part: I. (Double number).

No. 123. Upon the Origin of Alpineand Italian Lakes, Etc., Etc. Part II.

No. 124. The Quintessence of Socialism. By Prof. A. Schäffle.

(Darwinism and Polities. By David G. Ritchie, M A.

Administrative Nihilism. By Thomas Huxley, F.R.S.

No. 126. Physiognomy and Expression. By P Mantegazza. Illustrated. Part. I. (Double number).

No. 127. Physiognomy and Expression. Part II. (Double number).

No. 128. The Industrial Revolution. By Arnold Toynbee, Tutor of Baliol College, Oxford With a short memoir by B. Jowett. Part I. (Doublenumber).

No. 129 . The Industrial Revolution. Part II. (Double number).

No. 130. The Origin or the A ryans. By Dr. Isaac Taylor. Illustrated. Part I. (Double number). 
No. 131. The Origin of the Aryans. Part II. (Double number)

:0. 132 The Evolution of Sex. By Prof. $P$ Geddes and $J$ Arthur Thomson. Illustrated Part I (Double number).

No. 133. The Lvolution of Sex. Part II. (Double number)

No. 134. The kaw of Private Right. By George H Smith Double number).

No. 135. Capilal. A Critical Analysis of Capitalist Production. By Karl Marx. Part I (Double number.

No. 136. Capital. Part II (Double number)

No. 137. Capital. Part III. (Double number)

No. 138. Capital. Part IV (Double number)

No. 139. Lightning. Thunder and Lightning Conductors. Illustrated. By Gerald Molloy, D D, D Sc

No. 140 What is Mu-ic? With an appendix on How the Geometrical Lines have their Counterparts in Music By Isaac L. Rice.

No 141 . A re the Efrects of Use and Disu-e Inherited? By William Platt Ball

No 142 A vindication of the IRIghts of Woman. By Mary Wollstonecraft. With an Introduction by Mrs Henry Fawcet Part I. (Double number)

No. 143. A Vindication or the Rights of woman. Part II (Double number)

Noo 144. Civilization; Its Cause and Cure. By Edward Carpenter

No 145 Hody and Mind. By William Kingdon Clifford.

No. 146 Social Diseases and Worse Remedies. By Thomas H Huxley, F.R.S

No 147 The Soul or Man under Socialism. By Oscar Wilde.

No 148 Glectricity, the selence of the Nineteenth Century. By $\mathrm{E} C$ Caillard. (Illustrated) Part I. (Double number).
No 149. Flectricity. Part II.

No. 150. Degeneralion; A Chapter in Darwinism.' Illustrated. By $\mathrm{E}$ Ray Dankester, M.A., L-D., F.R.S. No. 15:. Mental vingestion By Di

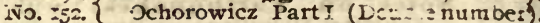
No. 153. Mental Suggention. Part II.

No. 154. $\{$ (Donble number)

No. 155. Mental Sugge-tlon. Part IIt.

No. 156. $\{$ (Double number)

No. 5 57. MI.ntal sugrention. Part IV.

No. 158. $\{$ (Double number).

No. 159. Modern Sclence; The Sclence of the Future. By Edward Car. penter.

No. 160. Siudi ins in Pessimism. By Schopenhauer.

No. 16x. (Flowers, Fruits and Icaves. Illustrated. By Sir John Lubbock, No. 162 . F.R.S. (Double number)

No. $\left.6_{3}\right\}$ Glimpies of Nature. Il'nstrated.

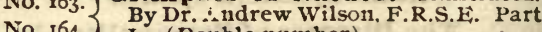
No. 164. I. (Double number).

No. 165 . Gilmpses of Nature. Part II.

No. 166 . Problems of the fuire. By Samuel Lang. Part I.

No. 167. Problems of the iruture. Part II. (Double number)

No. 268. Problems of the iruture. Part III. (Double number).

No. 169. The M .ral Teaching of Selence. By Arabella B. Buckley.

No. x70. Thr Wisdoni of wife. By Schopenhauer. (Double number).

No. 17x. The Mystery of Pail. By James Hinton.

No. 172. (What is Property? An inquiry No. 173 into the Principle of Right and of No. 174. Government. By P. J. Proudhon. No. 175. (Four double numbers, \$r.20).

No. 176. The History and Srope of Zoology. By E. Ray Lankester.

No. 177. Evolution and Ethics. By Prof. T. H. Huxley.

\section{A NEW SERIES.}

\section{The Social Science Library}

OF THE BEST AUTHORS.

\section{PUBLISHED MONTHLY AT POPULAR PRICES.}

\section{Paper Cover, 25 cents each; Cloth, extra, 75 cents each.}

\section{NOW READY.}

No. 1. SIx Centuries or Work and Wares. By James E. Thorold Rogers, M.P. Abridged, with charts and summary. By W. D. P. Bliss. Introduction by Prof. R. T. Elly.

No. 2. The Socialism of John Stuart Mili. The only collection of Mill's Writings on Socialism.

No. 3. The soefalism and Unsocialimm of Thomas Cariyle. A collection of Carlyle's social writings; together with Joseph Mazzini's famous essay protesting against Carlyle's views. Vol. I.

No. 4. The Sncialism and Unsocialism of Thomas Carlyle. Vol. II.
No. 5. Willinm Morris, Poet, Artist, Soriallst. A selection from his writings together with a sketch of the man. Edited by Francis Watts

No. 6. The Fabian E-mavs. American Edition, with Introduction and Notes by H. G. Wilshire.

No. 7. The Leonomies of Herber Spencer. By W. C. Owen.

No. 8. The Communism of Jolin Ruse kin.

No. 9. Horace Greeley and other Pio meers of American s clalism. By Charles Sotheran.

Special Number, 35 cents, in Paper Cover 


\section{LIST OF BOUND BOOKS}

\section{..IN.. \\ The Humboldt Library Series.}

The volumes of this series are printed on a superior quality of paper, and bound in extra cloth. They are from fifty to seventy-five per cent. cheaper than any other edition of the same books.

\section{STANDARD WORKS BY VARIOUS AUTHORS.}

A Vindication of the Right of Woman. With Strictures on Political and Moral Subjects. By Mary Wollstonecraft. New Edition, with an introduction by Mrs. Henry Fawcett. Cloth .......\$1.00

Electricity: the Science of the Nineteenth Ceniury. A Sketch for General Readers. By E. M. Caillard, author of "The Invisible Powers of Nature." With Illustrations. Cloth ........... 75 cts

IIental Suggestion. By J. Ochorowicz. Sometime Professor Extraordinarius of Psychology and Nature-Plilosophy in the University of Lemberg. With a Preface by Chas. Richet. Translated from the French by J. Fitzgerald, M.A. Cloth . . . . . \$2.00

Flowers, Fruits, and Leaves. By Sir John Lubbock, F.R.S., D.C.L.. LI.D. With Ninety-five Illustrations. Cloth ...75 cts

cilimpses of Vature. By Andrew Wilson, F.R.S.E., F.L.S. With Thirty-five Illustrations. Cloth.......... $75 \mathrm{cts}$

Problems of the Future, and Essays. By Samuel Laing, author of "Modern Science and Modern Thought," etc. Cloth . . \$1.25

The Naturalist on the River Amazon. A Record of Adventures, Habits of Animals, Sketches of Brazilian and Indian Life, and Aspects of Nature under the Equator, during Eleven Years of Travel. By Henry Walter Bates F.L.S., Assistant Secretary of the Royal Geographical Society of England. New Edition. Large Type. Illustrated, Cloth .............\$1.00

The Deliglons of the Ancient World: including Egypt. Assyria and Babylonia, Persia, India, Phonicia, Etruria, Greece, Rome. By George Rawlinson, M.A. Camden Professor of Ancient History, Oxford, and canon of Canterbury. Author of "The Origin "f Nations." "The Five Great Monarchies," Etc. Cloth ........... $75 \mathrm{cts}$
The Rise and Early Constitution of Universities, with a Survey of Medizval Education. By'S. S. Laurie, LI.D. Professor of the Institutes and History of Education in the University of Edinburgh. Cloth . . $75 \mathrm{cts}$

Fetichism. A Contribution to Anthropology and the History of Religion. By Fritz Schultze, $\mathrm{Ph} . \mathrm{D}$ Translated from the German by J. Fitzgerald, M.A. Cloth . . . . 75 cts

Money and the Mechanism of Exchange. By W. Stanley Jevons, M A., F.R.S., Professor of Logic and Political Economy in the Owens College, Manchester, England. Cloth .......... $75 \mathrm{cts}$

On the Study of Words. By Richard Chenevix Trench, D.D., A rchbishop of Dublin. Cloth ............ $75 \mathrm{cts}$

The Dawn of History. An Introduction to Prehistoric Study. Edited by C. F. Keary, M.A., of the British Museum. Cloth . . $75 \mathrm{cts}$

Geological Sketches at Home and Abroad. By Archibald Geikie, LI.D. F.R.S., Director-General of the Geological Surveys of Great Britain and Ireland.

Cloth ............. $75 \mathrm{cts}$

Illusions: A Psychological study. By James Sully, author of "Sensation and Intuition, "Pessimism," etc. Cloth . . $75 \mathrm{cts}$

The Pleasures of Life. Part $I$ and Part II. By Sir John Lubbock, Bart. Two Parts in One. Cloth ........... 75 cts.

English, Past and Present. Part $I$, and Part II. By Richard Chenevix Trench, D.D. Archbishop of Dublin. Two Parts in One. Cloth ........... $75 \mathrm{cts}$

Hypnotism: Its History and Present Development. By Fredrik Björnström, M.D., Head Physician of the Stockholm Hospital, Professor of Psychiatry, late Royal Swedish Medical Councillor. Cloth . . 75 cts 
The Story of Creation. A Plain Account of Evolution. By Edward Clodd, F.R.A.S. With over eighty illustrations. . . . 75 cts

Christianity and Agnostieism. A controversy, consisting of papers by Henry Wace, D.D., Prebendary of St. Paul's Cathedral; Principal of King's College, London. Professor : homas H. Huxley.-W. C. Magee, D.D., Bishop of Petersborough.-W. H. Mallock, Mrs. Humphrey Ward. Cloth . . 75 cts

Darvinism: An Exposition of the Theory of Natural Selection, with some of its applications. By Alfred Russel Wallace, LL.D., F.L.S. With portrait of the author, colored map, and numerous illustrations. Cloth ..........\$1.25

The ablest living Darwinian writer.-Cincinnati Commercial Gazette.

The most important contribution to the study of the origin of species and the evolution of man which has been published since Darwin's death. -New York Sun.

There is no better book than this in which to look for an intelligent, complete, and fair presentation of both sides of the discussion on evolution.-New York Herald.

Modern Seicnce and Irodern Thought. A Clear and Concise View of the Principal Results of Modern Science, and of the Revolution which they have effected in Modern Thought. With a Supplemental Chapter on Gladstone's "Dawn of Creation" and "Proem to Genesis," and on Drummond "Natural Law in the Spiritual World." By

S. Laing. Cloth . . . . . . . . 75 cts

Upon the Origin of Alpine and Italian hakes; and Uin Gla"ial Erosion. By A. C. Ramsay, F.R.S., Etc.; John Ball, M.R.I.A., F.L.S., Etc.; Sir Roderick I. Murchison, F.R.S., D.C.L., Etc.; Prof. B. Studer, of Berne; Prof. A. Favre, of Geneva ; and Edward Whymper. With an Introduction, and Notes upon the American I,akes, by Prof. J. W. Spencer, Ph.D., F.G.S , State Geologist of Georgia. Cloth........ 75 cts

Physiognomy and Expression. By Paolo Mantegazza, Senator; Director of the National Museum of Anthropology, Florence: President of the Italian Society of Anthropology. With Illustrations.

cloth ............\$1.00

The Industrial Ievolution of the Eighteenth renury in England. Popular Addresses, Notes, and other Fragments. By the late Arnold Toynbee. Tutor of Balliol College, Oxford. Together with a short memoir by B. Jowett, Master of Balliol College, Oxford. Cloth.......\$1.00

The Origin of the Aryans. An Account of the Prehistoric Ethnology and Civilization of Europe. By Isaac Taylor, M.A., Litt. D., Hon. L, L.D. Illustrated. Cloth ... \$1.00

The Lav of Private Right. By George H. Smith, author of "Elements of Right, and of the Law," and of Essays on "The Certainty of the Law, and the Uncertainty of Judicial Decisions," "The True Method of Legal Education," Etc., Etc. Cloth . . 75 cts
The Evolution of Sex. By Prof. Patrict Geddes and J. Arthur Thomson. With Io4 Illustrations. Cloth .......\$1.00

Such a work as this, written by Prof. Geddes who has contributed many articles on the same and kindred subjects to the Encyclopædia Brit tannica, and by Mr. J. Arthur Thomson, is not for the specialist, though the specialist niay find it good reading, nor for the reader of light lite? ature, though the latter would do well to grapp with it. Those who have followed Darwin Wallace, Huxley and Haeckel in their various publications, and have heard of the laterargu, ments against heredity brought forward by Prot. Weissman, will not be likely to put it dowrt unread. . . The authors have some extremely interesting ideas to state, particularly with regard to the great questions of sex and environment in their relation to the growth of life on earth. . . They are to be congratulated on the. scholarly and clear way in which they have handled a difficult and delicate subject.-Times.

\section{Capital: A Critical Analysis of Capi-} talistic Production. By Karl Marx. Translated from the third German edition by Samuel Moore and Edward Aveling, and edited by Frederick Engels. The only American Edition. Carefully Revised. Cloth, \$1.75.

The great merit of Marx, therefore, lies in the work he has done as a scientific inquirer into the economic movement of modern times, as the philosophic historian of the capitalistic era.-Encyclopadia Brillannica.

So great a position has not been won by any work on Econonic Science since the appearance of The Wealth of Nations. . : . All these circumstances invest, therefore, the teachings of thisparticularly acute thinker with an interest such as cannot be, claimed by any other thinker of the present day.-The Athenaum.

What is Property? An Inquiry into the Principle of Right and of Government. By P. J. Proudhon. Cloth .......\$2.06

Thd Philosophy of Misery. A System of Eiconomical Contradictions. By P. J Proudhon. Cloth ..........\$2.00

\section{Works by Professor Huxley.}

Evidence as to Iran's Place in NatureWith numerous illustrations

AND

On the Orimin of Species; or, the Causesof the Phenomena of Organic Nature.

Two books in one volume. Cloth . . . $55 \mathrm{ctc}$

The Physical Basis of Life. With other Essays

$$
\text { AND }
$$

Lectures on Erolution. With an Appen. dix on the Study of Biology.

Two books in one volume. Cloth . . . $75 \mathrm{cts}$ : 


\section{0,000 SOLD.}

\section{HYPNOTISM:}

ts History and Present Development. BY FREDRIK BJÖRNSTRÖM, M. D.,

Iead Physician of the Stockholm Hospital, Professor of Psychiatry, Late Royal Swedish Medical Counselor.

Authorized Translation from the Second Swedish Edition.

BY BARON NILES POSEE, M. G., Director of the Boston School of Gymnastics.

'aper Cover (No. II3 of The Humboldt Library), - - 30 Cents :loth, Extra, " "

\section{PRESS NOTICES.}

The learned Swedish physician, Björnström.-Churchman.

It is a strange and mysterious subject, this hypnotism.-The Sun.

Perhaps as concise as any work we have. $-S$. California Practitioner.

We have found this book exceedingly interesting.-California Homapath.

A concise, thorough, and scientific examination of a little-understood subject.-Episcoal Recorder.

Few of the new books have more interest for scientist and layman alike.-Sunday imes (Boston).

The study of hypnotism is in fashion again. It is a fascinating and dangerous study.oledo Bee.

It is well written, being concise, which is a difficult point to master in all translations.?edical Bulletin (Philadelphia).

The subject will be fascinating to many, and it receives a cautious yet sympathetic eatment in this book.-Evangelist.

Ore of the most timely works of the hour. No physician who would keep up with the mes can afford to be without this work.-Quarterly Journal of Inebriety.

Its aim has been to give all the information that may be said under the present state of ar knowledge. Every physician should read this volume.-American Medical Journal it. Louis).

It is a contribution of decided value to a much-disussed and but little-analyzed subject 7 an eminent Swedish alienist known to American students of European psychiatry. 'edical Standard (Chicago).

This is a highly interesting and instructive book. Hypnotism is on the onward march the front as a scientific subject for serious thought and investigation.- The Medical Free ress (Indianapolis).

Many of the mysteries of mesmerism, and all that class of manifestation, are here eated at length, and explained as far as they can be with our present knowledge of psyiology.- New York Journal of Commerce.

The marvels of hypnotic phenomena increase with investigation. Dr. Björnström, in is clear and well-written essay, has given about all that modern science has been able to evelop of these phenomena.-Medical Visitor (Chicago).

It has become a matter of scientific research, and engages the attention of some of the remost men of the day, like Charcot, of Paris. It is interesting reading, outside of any iefulness, and may take the place of a novel on the office table.-Eclectic Medical Joural (Cincinnati).

This interesting book contains a scholarly account of the history, development, and ientific aspect of hypnotism. As a whole, the book is of great interest and very instrucve. It is worthy of careful perusal by all physicians, and contains nothing unfit to be read it the laity.-Medical and Surgical Reporter (Philadelphia).

To define the real nature of hypnotism is as difficult as to explain the philosophy of toxic - therapeutic action of medicine-more so, indecd. None the less, however, does it beoove the practitioner to understand what it does, e ren if he cannot tell just what it is, or ow it operates. Dr. Björnström's book aims to give a general review of the entire subject. - Medical Record. 


\section{COMPLETE SETS OF}

\section{THE HumBOLDT LIBRARY}

CAN BE OBTAINED UNIFORM IN SIZE, STYLE OF BINDING, ETC.

The Volumes average 600 pages each, and are arranged thus:

Volume I. Contains Numbers............................. II

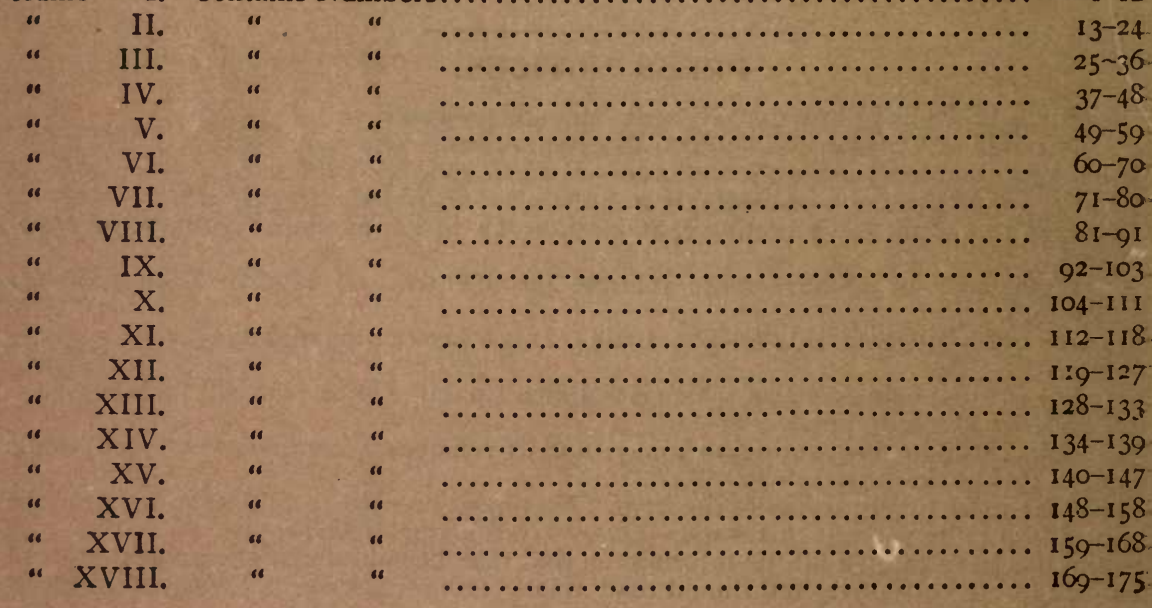

CLOTH, EXTRA, \$2.00 PER VOLUME, OR $\$ 36.00$ FOR 18 VOLUMES.

The various books contained in this Library of $18 \mathrm{vol}$ umes would cost over $\$ 300$ if bought in separate volumes. as published in London and New York. 


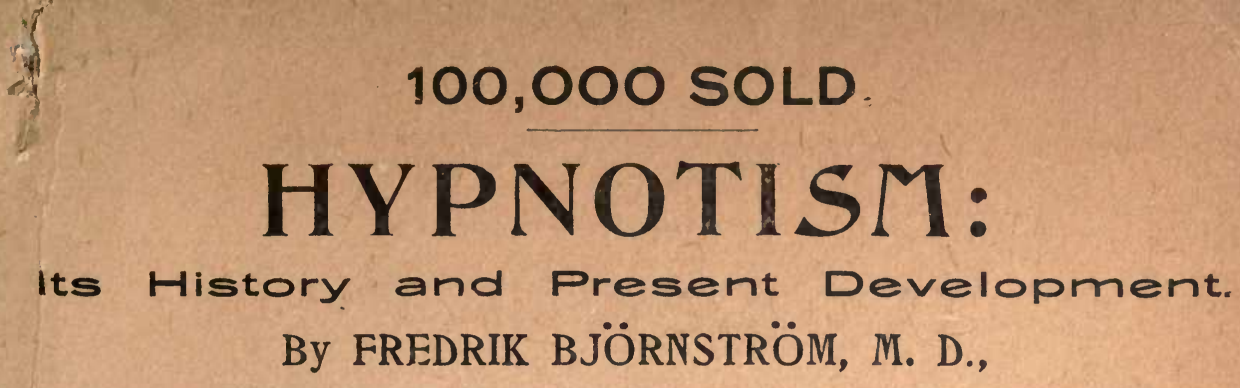

Head Physician of the Stockholm Hospital, Professor of Psychiatry, Late Royal Swedish Medical Counselor.

Authorized Translation from the Second Swedish Edition.

BY BARON NILES POSEE, M. G.,

Director of the Boston School of Gymnastics.

Paper Cover (No. II 3 of The Humboldt Library), - $\quad$ - 30 Cents

Cloth, Extra, " : " " - . 75 Cents

PRESS NOTICES.

The learned Swedish physician, Björnström.-Churchman.

It is a strange and mysterious subject, this hypnotism.-The Sun.

Perhaps as concise as any work we have.-S. California Practitioner.

We have found this bouk exceedingly interesting.-California Homapath.

A concise, thorough, and scientific examination of a little-understood subject.-Episcopal Recorder.

Few of the new books have more interest for scientist and layman alike.-Sunday Times (Boston).

The study of hypnotism is in fashion again. It is a fascinating and dangerous study.Toledo Bee.

It is well written, being concise, which is a difficult point to master in all translations.Medical Bulletin (Philadelphia).

The subject will be fascinating to many, and it receives a cautious yet sympathetic treatment in this book.-Evangelist.

One of the most timely works of the hour. No physician who would keep up with the times can afford to be without this work.-Quarterly Journal of Inebriety.

Its aim has been to give all the information that may be said under the present state of our knowledge. Every physician should read this volume.-American Medical Journal (St. Louis).

- It is a contribution of decided value to a much-disussed and but little-analyzed subject by an eminent Swedish alienist known to American students of European psychiatry. Medical Standard (Chicago).

This is a highly interesting and instructive book. Hypnotism is on the onward march to the front as a scientific subject for serious thought and investigation.- The Medical Free Press (Indiana polis).

Many of the mysteries of mesmerism, and all that class of manifestation, are here treated at length, and explained as far as they can be with our present knowledge of psychology:-New York Journal of Commerce.

The marvels of hypnotic phenomena increase with investigation. Dr. Björnström, in this clear and well-written essay, has given about all that modern science has been able to develop of these phenomena.-Medical Visitor(Chicago).

It has become a matter of scientific research, and engages the attention of some of $c_{1} \mathrm{E}$ foremost men of the day, like Charcot, of Paris. It is interesting reading, outside of any usefulness, and may take the place of a novel on the office table.-Eclectic Medical Journal (Cin cinnati).

This interesting book contains a scholarly account of the history, development, and scientific aspect of hypnotism. As a whole, the book is of great interest and very instructive. It is worthy of careful perusal by all physicians, and contains nothing unfit to be read by the laity.-Medical and Surgucal Reporter (Philadelphia).

To define the real nature of hypnotism is as difficult as to explain the philosophy of toxic ir therapeutic action of medicine-more so, inderd. None the less, however, does it behoove the practitioner to understand what it does, even if he cannot tell just what it is, or how it operates. Dr. Björns!röm's book aims to give a general review of the entire subject. - Medical Record. 
SOLD ONLY BY SUBSCRIPTION.

\title{
COMPLETE SETS OF
}

\section{THE HuMBOLDT LibRARY}

CAN BE OBTAINED UNIFORM IN SIZE, STYLE OF BINDING, ETĆ.

The Volumes average 600 pages each, and are arranged thus:

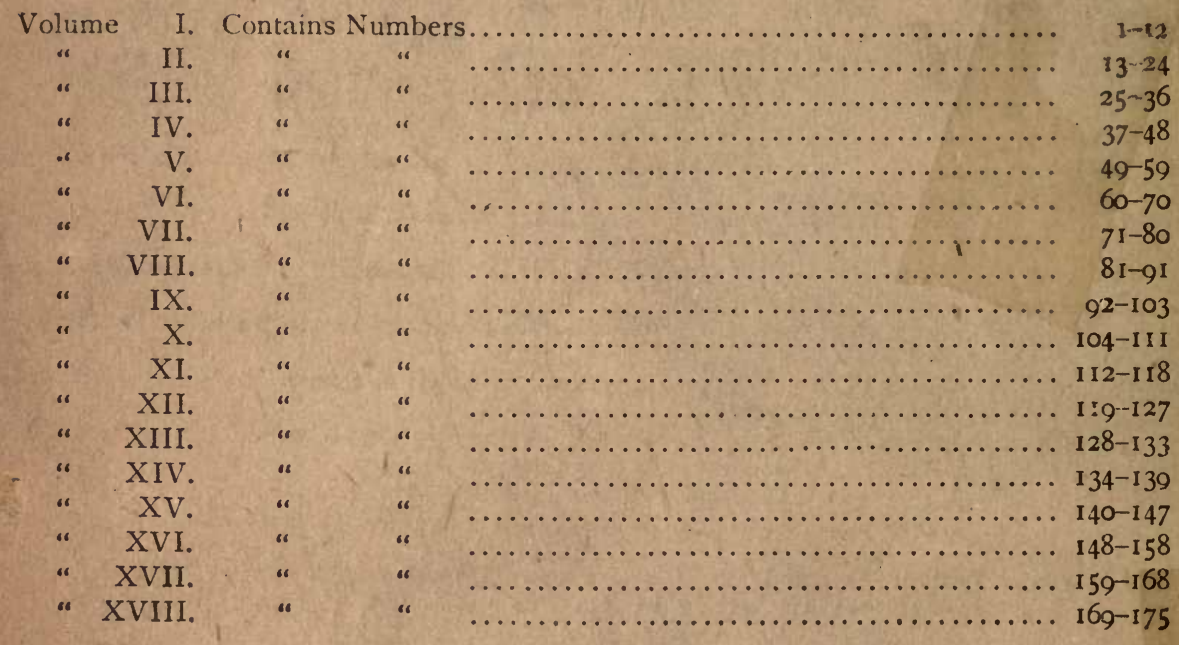

CLOTH, EXTRA, \$2.00 PER VOLUME,

OR $\$ 36.00$ FOR 18 VOLUMES.

The various books contained in this Library of $18 \mathrm{vol}-$ umes would cost over $\$ 300$ if bought in separate volumes as published in London and New York.

\author{
PUBLISHED AND SOLD BY
}

THE HUMBOLDT PUBLISHING CO.,

64 Fifth Ave., New York. 
RETURN CIRCULATION DEPARTMENT

TO $\rightarrow 202$ Main Library

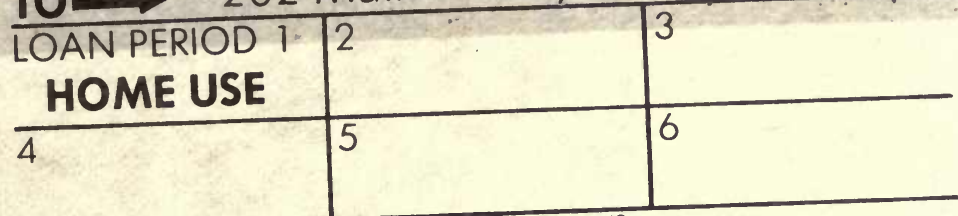

- HOME USE

ALL BOOKS MAY BE RECALLEd by calling 642.3405

1-month loans may be renewed by ballinging books to Circulation

Desk

Desk

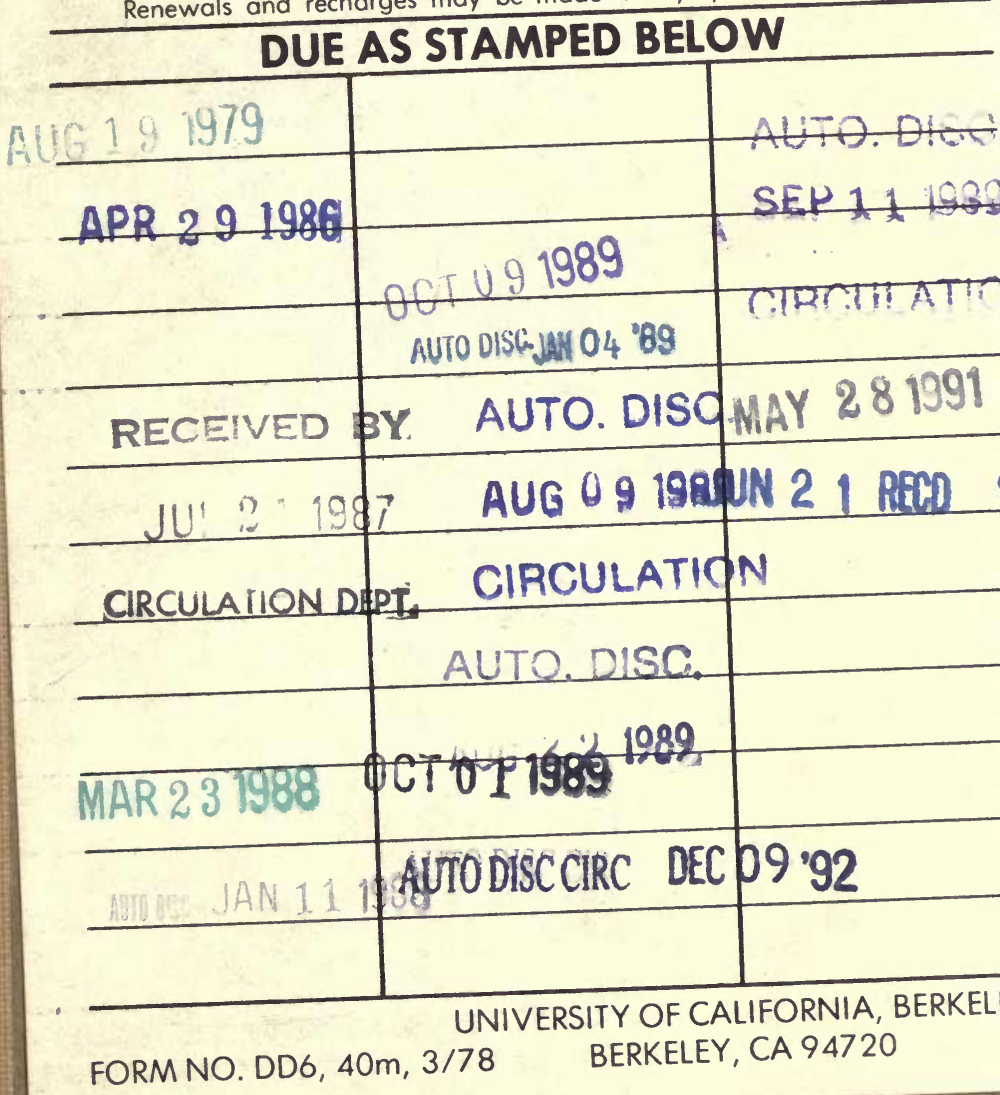




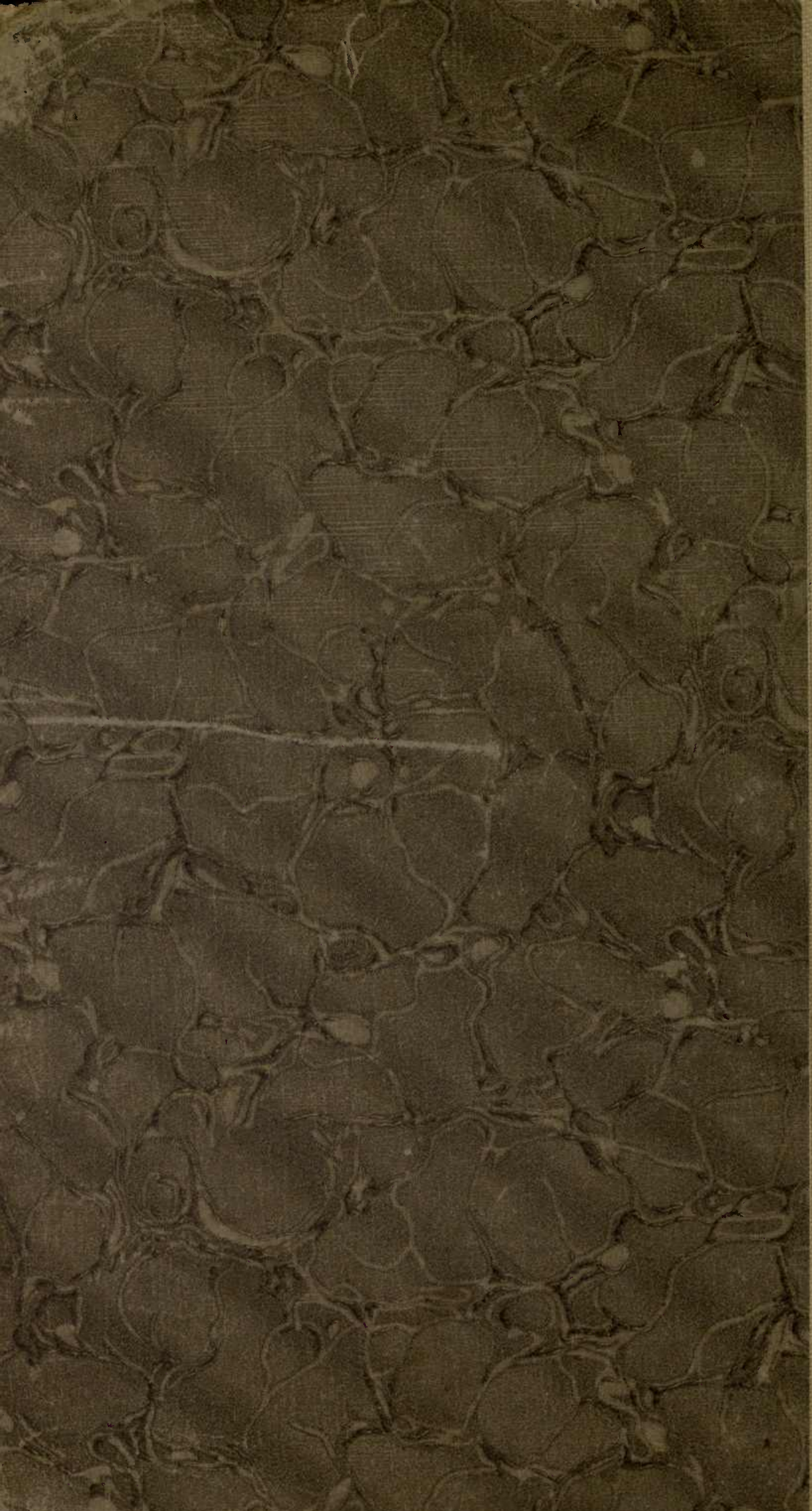

